

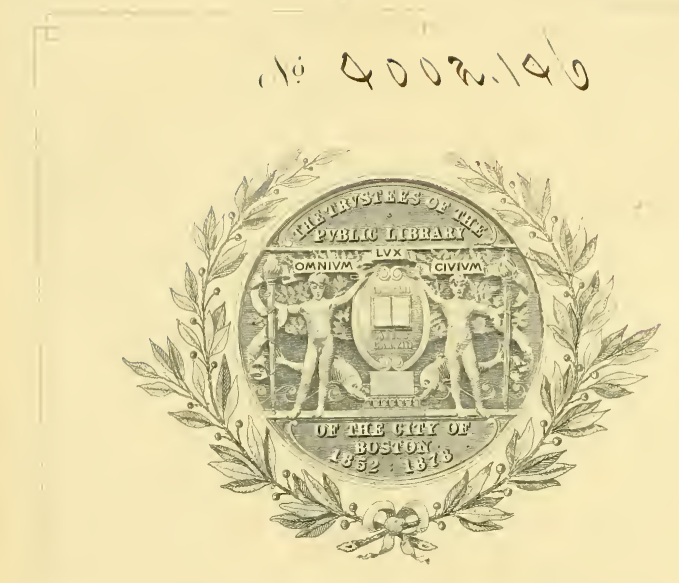


APR 26 A

?

: 






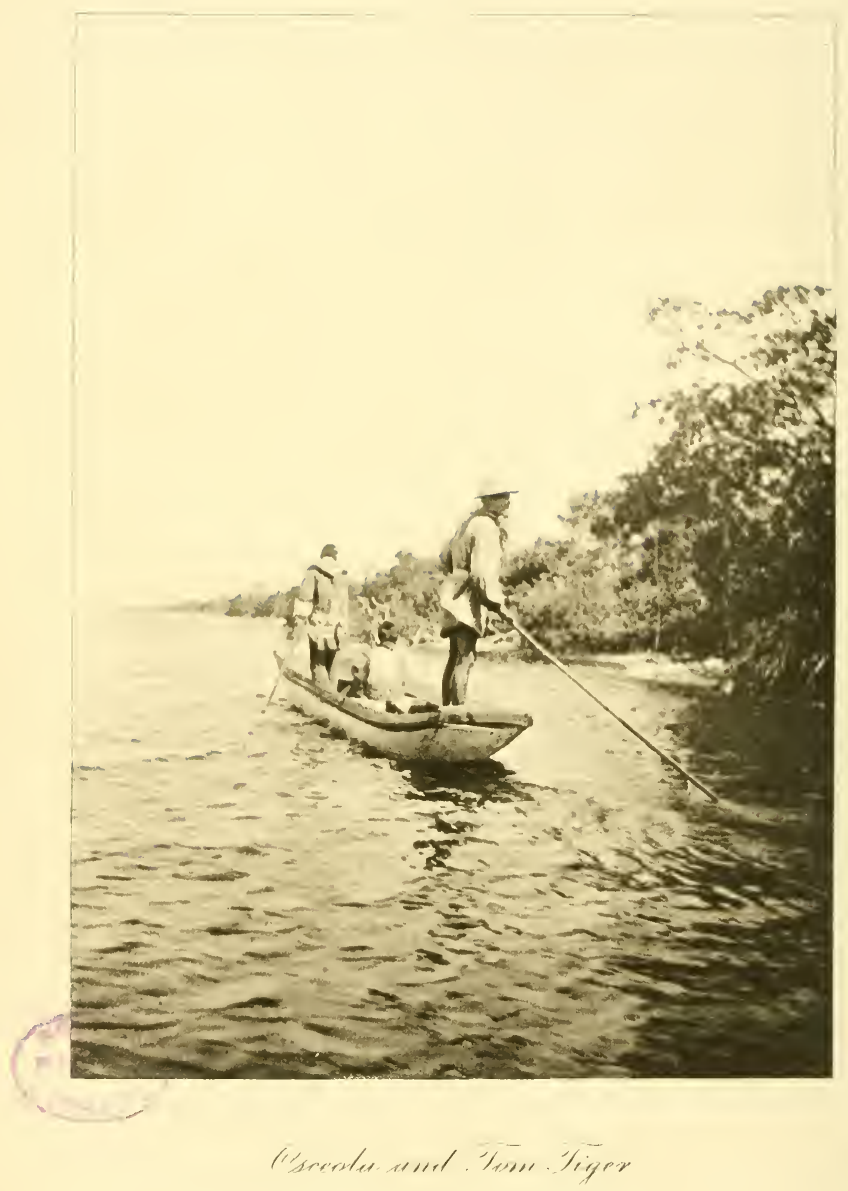




\section{HUNTING AND FISHING}

$1 \%$

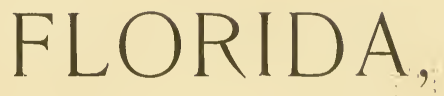

INCLUIONG A

\section{KEY TO THE WATER BIRDS}

KNOII TOQCEUR IN THE STATE.

BY

\section{CHARLES B. CORY.}

Curator of the Department of Ornithology in the Field Columbian Museum, Chicago; Fellow of the Linnæan and Zoölogical societies of London; Member of the American Ornithologists' Union; of the British Ornithologists' L'nion; Honorary Member of the California Academy of Sciences, etc., etc.

AUTHOR WF

"The Beattiful aNo Curious Birds of the WORlo," "The Birds OF THE BAHAMA IsLANis," "THE litrds OF HAITI AND SAN Domingo," "The Birds of the West Indies," "A NatuRAList in the Magdalex IsLands," etc., etc.

FUR SALE JII

ESTES \& LAURI.I T, IBOSTON, MASS.

ISg6. 
Copyright, I895, by

CHARLES B. CORY.

Boston, Mass. 
TO MY WIFE,

WHO HAS OFTEN SHARED WITH ME THE PLEASURES

AND TRIALS OF CAMP LIFE, THIS

BOOK IS DEDICATED. 



\section{CONTENTS.}

PREFACE . . . . . . . . . . . . . . . 3

INTRODUCTION

THE SEMINOLE INDIANS.

Manners and Customs . . . . . . . . . . . . . . . . 9

Green Corn 1)ance . . . . . . . . . . . . 16

Clothing and Ornaments . . . . . . . . . . . 20

Method of Hunting . . . . . . . . . . . . . . . . 24

Location of Villages . . . . . . . . . . . . . . 30

Seminole History . . . . . . . . . . . . . . . . . 32

Vocabulary . . . . . . . . . . . . . . . . . . . 35

THE Floriba PANTHER . . . . . . . . . . . . . . . . . . . 4 I

A PANTher Hunt . . . . . . . . . . . . . . . . . . . . 44

The Black BeAR . . . . . . . . . . . . . . . . . . . . 50

DEER . . . . . . . . . . . . . . . . . . . . . . . . I

Mllifiators ANI CRocomiles.

Alligators . . . . . . . . . . . . . 65

Crocodiles . . . . . . . . . . . . . . . 70

TURKEYS . . . . . . . . . . . . . . . . . . . . . . . . 73

TARPON FishING . . . . . . . . . . . . . . . . . . . 75

HLXTING GROUNDS OF FLORIDA . . . . . . . . . . . . . . . . So

The MaMmals of Florid . . . . . . . . . . . . . . . . . . . . IO9

REMARKS ON SOME OF THE FlORIDA SNAKES . . . . . . . . . . . I 24

KEY to THE ITATER BiRdS OF FloRidA . . . . . . . . . . . . . 133

Introduction to Bird Key . . . . . . . . . . . . . . 135

Measurements . . . . . . . . . . . . . . . 136

Glossary . . . . . . . . . . . . . . $13 \AA$ 



\section{LIST OI: ILIUSTRATIONS.}

SEMIXOLE CAMP FIRE:

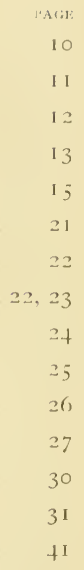

HA:A:

THE SOFKEE SPOON .

BARFOTARTSO, "OLI) (HARIA: "

(IARTSL N-E-TEL-E-K EE, ROHERT ()SCEOLA

Movixg CamP .

JACK CHARLHE

BHLY BoWLEGS

INDHAN CHLDREN

MANATEE

AFTER MANATEE

BOATING;

HARPOON

INDIA CAMP, NEW RIVE

GROUP OF INDIANS .

FLORIDA PANTHER

JOHX DALI

$+3,97,103$

1) EAD P.ATHER

BLACK BEAR

P'AT AND GALE, WITH Trip, DO(, AND TIGER

BEARS

$5+, 55$

RATTLESNAKE.

DEER

$61,62.63$

AlejGitior $65.66,67.68$

CROCOHILE:

$70,71,72$

TARP(IN

. 76,77

THE LEAI OF THE TARPON 
LIST OF ILLUSTRATIONS.

"GAFFING" A TARPON

PAGE

A "l'ONT" ON (2UALL

Tom

So

Rolin and Prince "PoINtixg" Quall

SI

Rolix ANI PRINCE

SI

Duck SHOOTIXg WhH DecoYs . 83.84

A Big BAG

WILI I)UCK 86,87

Whon Cat Clamixg a TreE 8.5

WIL1) CAT sio

AFter A Whid Cat 90

LARGE WILL CAT 90

RACCOON . Q) 1

An L XFAIR Fight () 2 opossum . 92,123

A (IREAT D)AY FOR KIXgFISH 93

Thornton's Camp, Hulshoko River (1) 4

The OLA PUMP 95

The Edie of the Everglanes . . . . . . . . . . . . . . 96

A SANU Hill CRANE'S Nest . . . . . . . . . . . . . . 98

1)EAD SHARK, NeW River INLET . . . . . . . . . . . . . . . 99

The Miam RIVER RaPins . . . . . . . . . . . . . . . IOI

MHAM RIVER . . . . . . . . . . . . . . . . . . . 102

Rattlesnake AbOUt to Strike . . . . . . . . . . . . . . 125

Rattlesnake Prepariag to Strike . . . . . . . . . . . 126

WATER BIRDS OF FIORIIA . . . . . . . . . . . . 1 . 1 to 207 


\section{PREFACE.}

Mucu of the matter contained in the following pages was written in the field and covers a period of some ten winters in Florida, a great deal of the time being passed in out-of-the-way localities while studying the fauna of the State. The illustrations are, with few exceptions, from photographs taken by myself; the principal exceptions being the photographs of the tarpon, which were obtained through the kindness of Mr. George Mixter, of Boston. The picture of the manatee and the illustrations in the ". Key to the Water Birds" are the work of Mr. Edward Knobel, of Boston.

The nomenclature and classification used in the Key is that adopted by the American Ornithologists' Union.

I have aimed to make the "Key to the Water Birds" one which would enable a person unfamiliar with birds to identify any Florida species without ditliculty. Before using the key the reader should carefully read the "Introduction to the Key" and make himself familiar with the terms used in describing birds; the general rules for neasurements, etc.

With few exceptions, the species given have been taken or observed by myself during my various trips to Florida, but several are included on the authority of others, and I have freely availed myself of information obtained from the following works and papers :-

" History of North American Birds," by Baird, Brewer, and Ridgway: " Manual of North American Birds," by Robert Ridgway : " Key to North American Birds," by Elliot Coues: " Birds of Eastern North America," by C. J. Maynard: " Handbook of the Birds of Eastern North America," by F. M. Chapman: "Notes on the Birds of the Caloosahatchee Region of Florida," by W. E. D. Scott (Auk Vol. IX., pp. 209-2I8). 
“On the Mammals and Winter Birds of East Florida," by J. A. Allen (Bull. Mus. Comp. Zool., II., I87 I, pp. I68-I85): “ Catalogue of the Mammals of Florida," by C. J. Maynard (Bull. Essex Inst, IV., I872, pp. I35-I $\left.7^{8}\right)$; “The Mammals of Florick," by C. J. Maynard (Quart. Journ. Bost. Zool. Society, II., I883, Pp. I-8, I7-24, $\left.3^{8-43}, 49,50\right)$ : "Contributions to the Nammalogy of Florida," by Samuel N. Rhoads (Proc. Acad. Nat. Science, Philadelphia, I894, pp. I52-160) ; “A Monograph of the Bats of North America," by Harrison Allen, I893; " Remarks on Certain Land Mammals from Florida, with a List of the Species Known to Occur in the State," by Frank M. Chapman (Bull. Am. Mus. Nat. Hist., VI., I89t, pp. 333-3+6) : "Kurse Notizen uber die hohere Fauna Floridas," von Dr. Einar Lonnberg, Upsala, Sweden, Is9t.

I have also consulted the following works relating to the Florida Indians: “The Seminole Indians of Florida,” by Clay MacCauley, and "Archives of Aboriginal Knowledge," by H. R. Schoolcraft. 


\section{IN'TRODUGTION.}

MY first hunting experience in Florida dates back to the year I877, and I have since spent ten winters in the State, much of the time being deroted to exploring out-of-the-way nooks and corners which were then visited by but few people, and it was a journey of several days to places which, since the advent of railroads, may now be reached in as many hours. Lake Okeechobee is now no longer difficult of access and many people visit it every year from Kissimmee and Fort Myers. From Jacksonville to the Indian River, which but a few years ago was a three days journey, may now be done by rail in a few hours. Although Florida is now annually risited by thousands instead of hundreds of people, as was the case a few years ago, there is still a vast extent of country which is practically a wilderness and where game is yet to be found in great abundance; and the magnificent winter climate of Florida adds much to the enjoyment of the hunter or fisherman.

Many there are who look with disfavor upon him who with rifle and hound wanders into the wilderness to hunt and kill wild animals. To such an one I would say, "Chacque un a son gouté." If he be a man, with a man's health and strength, his hand steady. and his eye clear, let him go with me and camp for a week on the bank of some unnamed lake in the Florida wilderness, where the panther, bear, and deer wander undisturbed. Let him breathe the fresh morning air full of the smell of the pines, and listen to the chorus of the hounds as they dash away in full cry on the hot trail of something that can fight as well as run. I warrant you his pulse will quicken as he forces his way into some thicket where the dogs hold a bear or a panther at bay. Perhaps many of us have a trace of the savage left in us yet, but I believe the boy who loves the woods will gain much in health and manhood; and it is pleasant to think 
that when we are gone those that come after us may wander where we have wandered, may camp where we have camped, and use the wun or the rod as well or better than we have used it. knowing that they will go back to their fellows and the cares of life better in mind and body for the experience.

As Isaac Walton tells us, it was one of the qualifications that Xenophon bestowed on Cyrus, " that he was a hunter of wild beasts," and the love of the chase seems to be as strong with many of us now as then. As we grow older, however, most of us lose something of our desire to kill game. Our love for the woods seems to increase rather than diminish and we see many new and beautiful things in the wilderness which we did not see when we were younger: but we shrink from killing a bird or mammal unless we actually need it for food or study.

Many a flock of quail or ducks I have watched feeding without disturbing them, and many a deer I have stalked, and perhaps photographed, and then watched it from my concealment until, discovering my presence, it bounded away unharmed. It should be a rule with every true sportsman never to kill more game than can be properly used. Of course, with a number of men in camp, what appears to be a large bag is often not more than is actually needed for food. On several occasions I have made large bags when some of the men in camp were going to spend a holiday with their families and wished to take home some birds: but the wanton and useless slaughter of game cannot be too strongly condemned. 


\section{THE SEMINOLE INDIANS.}

\section{MANNERS AND CUSTOMS.}

Ayoxg the Seminole Indians in Florida exist certain tribal organizations or clans known as "gens," which comprise families and their unmarried relatives. In the old days these gens were well known; but at the present time many of them have either become extinct or their members are so few and scattered that they are no longer recognized.

These gens were known under various names, such as Tiger, Deer, Bear, Wind, and many others, the members of the same "gen" not being allowed to intermarry.

A Seminole Indian rarely kills more game than he can use; if he does not need the meat, he either sells it or cures it for future use, the venison being cut into strips which are smoked slightly over the camp fire and afterwards dried by the sun.

An Indian camp fire will burn for a long time and consume comparatively little wood. A number of logs are arranged in a circle with their ends together, somewhat resembling the spokes of a wheel; the fire is lighted in the center where the ends meet, and when the fire is no longer needed the logs are drawn apart and it immediately dies down; but the charred ends may easily be ignited again when required.

This fire is an admirable one for camp cooking. as it is comparatively small and easily regulated.

The camp fire is rarely allowed to go out, a pot of sofkee or stewed meat generally being kept warm, especially in a camp where there are many children.

". Sofkee" is a kind of soup made from ground corn or hominy and corn mixed. It is eaten with large wooden spoons which the Indians manufacture and which are called sofkee spoons. These they hand 
from one to the other as they sit about the pot, each drinking a ladleful before passing it on to the next. Another favorite food is called "kumpty" or "coontie." The " coontie" Hour is made from the root

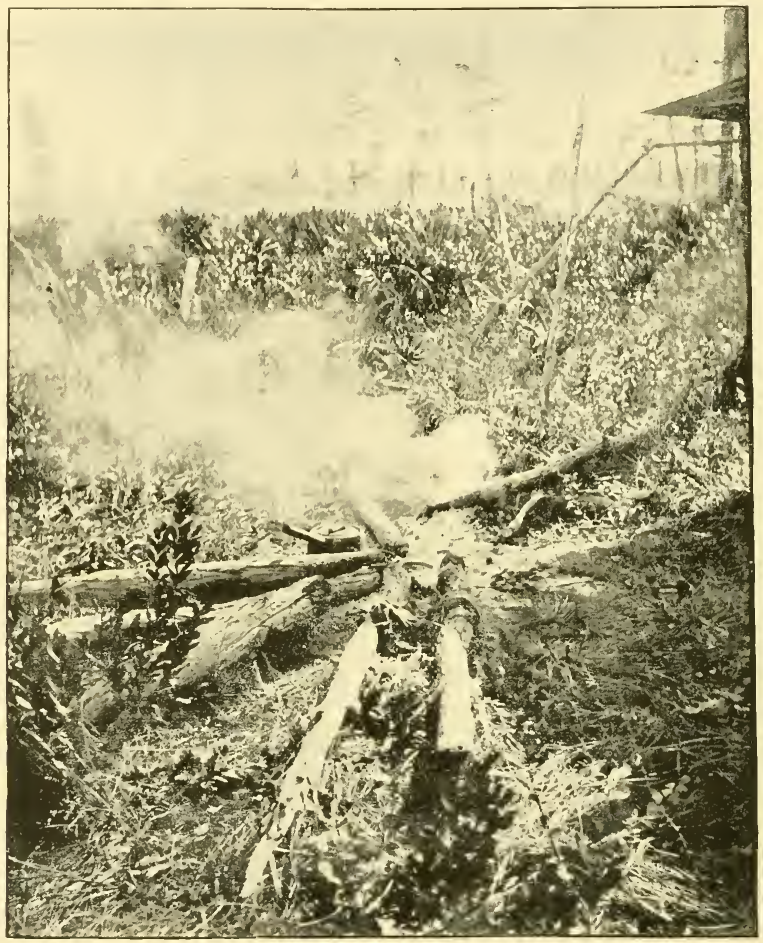

SEMINOLE C.AMP FIRE.

of a plant which grows in the dry, sandy lands of South Florida and is very plentiful in some localities. The root of the plant alone is used. This is first carefully peeled and washed, after which it is thrown into a 
large wooden vessel or trough, where it is ground and pounded into a powder; this powder is then carefully washed, and after repeated washing becomes very white and clean. If it is not entirely free from dirt upon being wet it assumes a pale pinkish color, but if thoroughly cleansed it remains perfectly white. This is called " coontie" by the

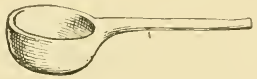

THE SOFKEE-SPOON. Indians, and is prepared much in the same manner as we use cornstarch or arrowroot. It is sometimes mixed with wheat flour and made into cakes, which when fried are very palatable. The seeds of the kumpty plant are contained in a cone having the general appearance of a pine cone about to sprout. They resemble kernels of corn, but are larger and flatter and of an orange-red color.

The Indian does little in the way of farming. He clears small hummocks and plants corn, pumpkins, sweet potatoes, and sometimes raises a little maize; in some of the camps he has bananas growing and a few orange or lemon trees, but, as a rule, he raises barely enough to supply himself and family a part of the year.

I have been unable to learn anything definite of the Indian law's regarding punishment of crime. That they do have such laws is known. Years ago Old Charlie was condemned to have the upper portion of his ears cut off and was banished for one year from the tribe under penalty of death if he returned. He is one of the nicest old Indians of the lot, but lost his ears for "talking too much," as the Indians say.

Upon the death of an Indian the body is clothed in a new shirt, and usually a handkerchief is tied around the neck and a new turban put about the head. Sometimes the face is painted, usually with a round spot on each cheek. A piece of burnt wood is placed in the left hand and a bow and one arrow is usually buried with him. When the place for burial is selected the ground is prepared in the following manner: A floor of palmetto $\log$ is built some seren feet long by three feet wide, over which a roof of palmetto leaves is constructed. The body is placed in this small house, the feet, it is 
claimed, being always placed toward the East. The body is usually wrapped in a blanket and covered with logs, forming a kind of box with the palmetto leaf roof over it. A fire is built at the end of the

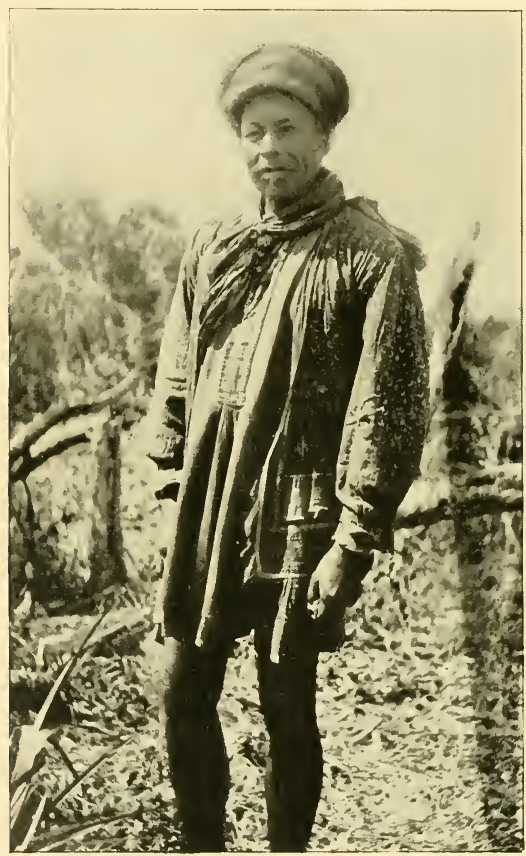

BARFOTARTSO, " OLI' CHARLIE.", tomb, which is renewed at sunset for three days, and lighted torches waved about for a few moments to frighten away the "bad bircls." After the third day the fires are allowed to go out.

In talking with Old Charlie and Osceola about the mounds which are so common in Florida, I asked who made them, and they answered, “ Injuns all dead. One old chief tell me long time "go, Injuns came in canoe, eat oysters, play ball."

Old Charlie said the Indians were not Seminoles.

Most of the Indians have but one wife, but two at least, Old Charlie and Old Doctor, have two. I have been told that Old Doctor was presented with a second wife by his tribe, in recognition of his services to his brother Indians in killing a negro half-breed named Key-West Billy.

This half-breed came back to his tribe and demanded in marriage one of the Inclian girls. It is claimed that, upon being refused, he 
immediately shot several persons, including a woman. This was objected to by Old Doctor, who happened to be present, and he in turn shot Billy, killing him instantly.

Indians rarely talk much and do not like to answer questions. It

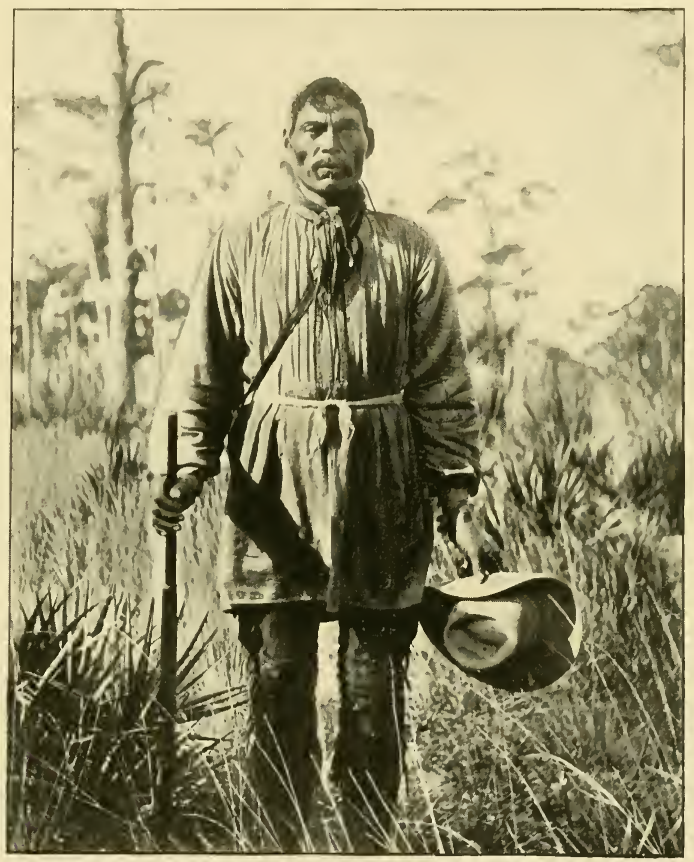

GART-SUM-E-TEL-E-KEE. ROBERT OSCEOLA.

is only after being for some time in their company and gaining their confidence that they will talk freely about anything connected with themselves.

The Indians tan the skins of the animals which they kill by 
carefully scraping them and working them in their hands until they become soft and pliable. They also use the brains of the animal for softening and curing the skin.

The leggings which they wear are sometimes dyed a very rich mahogany brown by soaking the skin in an infusion of mangrove bark. The bark is boiled for several hours; the skin is then immersed in the liquid for half an hour. It is then taken out and dried in the sun until it is merely moist, although it will not do to let it get entirely dry. It is then immersed a second time for about half an hour, and upon being taken out and dried it is ready for use.

The brain-tanned skin, which has not been dyed, becomes very hard and stiff when wet unless it is continually worked over and kept soft by manipulation, but skins which have been prepared by tanning with mangrove bark are very little affected by rain, and make very pretty leggings and moccasins.

It is rare that the Seminoles ornament their moccasins with beads, and I have seen but two pairs of moccasins made in this manner: one I procured from Old Doctor, who brought them into Lantana just as I was coming out from a hunting expedition. The old man was anxious to dispose of them to get money to buy whisky. They were neatly ornamented with lines of beads.

Old Doctor was one of the Indians that took part in the last war. Ite is still hale and hearty and does not like a white man any better than he ever did.

I have asked a number of Indians regarding their antidote for snake poison, and have been told by two or three different ones with whom I was well acquainted that they had no antidote for the bite of the rattlesnake. Both Osceola and Old Charlie had no reason for deceiving me, as they told me many things about their manners and customs, and often evinced their good feelings toward me by making me presents of sweet potatoes, eggs, and venison.

Osceola's wife was once bitten by a moccasin, and I am told that the wound did not heal for nearly a year, and at times she was troubled with fever, which may or may not have been the result of the bite.

At many of the camps the Indians now keep hens and pigs. In 
moving from one camp to another they take the pigs about with them.

One or two of the Indians have an old wagon and some very diminutive horses. Osceola has two perfectly white horses, strong, hardy little animals, which draw about an old wagon when he moves from place to place. Usually, the squaws and pappooses ride in the wagon, while the men walk, and the pigs are tied underneath or else led by a squaw.

It was at one time customary for hunting parties to wander some distance to the north and to the south of their present settlements, and

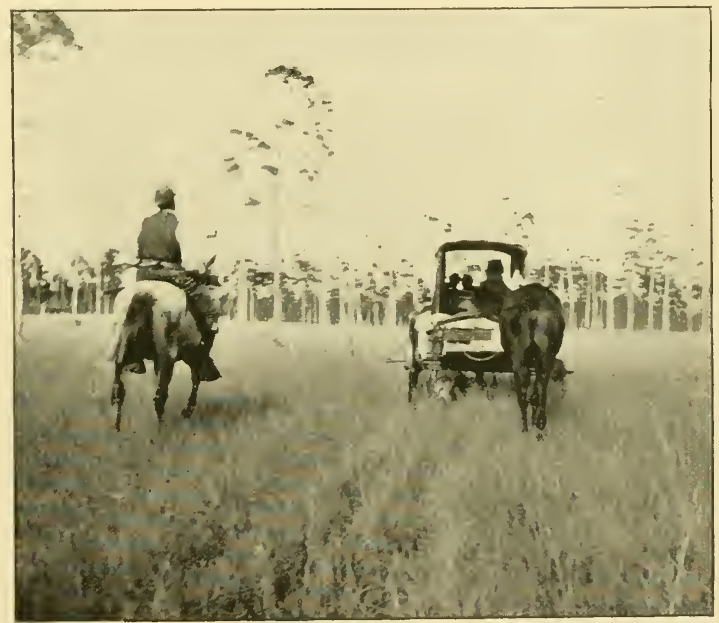

MOVIN: CAMP.

the remains of old Indian camps may be found to the extreme southeast point of Florida: but none were observed on the southwest portion of the State below White Water Bay.

The costume of an Indian in camp usually consists of a cotton 
shirt. The women wear a cotton dress embroidered with many pieces of colored calico. The young children run about naked until they arrive at the age of eight or ten years, when they are given a cotton shirt. Sometimes the small children wear some sort of covering during the cold weather.

The Indians visit each other a great deal. Many of those living on New River go to the Big Cypress every year, usually to attend the Green Corn Dance and visit their relatives.

\section{GREEN CORN DANCE.}

The annual festival known as the Green Corn Dance is still observed by the Indians, but it is not conducted with the same ceremony as in bygone years.

In the old days the Green Corn Dance or "Busk" was an occasion of great importance with the Creek tribe. It then occupied seven or eight days, but is now reduced to four or at most five days.

It takes place during the second week in June or during the " little moon in June," as the Indians say.

It is very difficult to obtain from the Indians a description of this dance. From time to time they would answer a few questions, but if pressed for information they immediately become reticent. The dance usually lasts four days, according to the statement of most of the Indians, although some claim that it is decided by the medicine man whether it shall last four or five days. Two weeks previous to the day of the dance notice is sent by Indian messengers to the different clans and villages stating the date of the ceremony. They keep account of the days which intervene by hanging up a number of small sticks representing the days, and one is taken down each day. When the last one is thrown away they repair to the point selected for the feast.

On the evening of the first day the ceremony of taking the " black drink" occurs. It is believed that unless one drinks of this he will be "sick" after eating the green corn. It is not as carefully carried out as in the old days, and I do not understand that the fire is now 
lighted by rubbing two sticks together. At the present time the fire is started by the medicine man, and the squaws are not allowed to come near the fire, which is still reserved, as in ancient days, for the warriors who drink the black drink.

In building this fire they place the sticks pointed to the four points of the compass, and, in fact, the Indians at all times arrange their logs by placing all the ends together, somewhat resembling the spokes of a wheel, which is probably a traditional method of building a fire, possibly originated by the ceremony of the Green Corn Dance or Busk.

The Indian women attach strings of turtle shells filled with pebbles (seven on each string) to their legs. While the dancing goes on the women stamp about, rattling these shells, keeping time with the dancers.

I have never seen a white man who has attended a Green Corn Dance, but I have been told there are several who have done so, although it is claimed they have not been allowed to remain during the entire celebration. The dance usually lasts from four to five days. The first day they do a great deal of dancing, which is carried on far into the night. When one Indian becomes tired another takes his place, and sometimes a half a dozen or more dance together. After this the dancing is intermittent. The second day the young men go out and bring in game for the feast: the third and fourth days are spent in feasting and drinking. This is the official program, but I am afraid the affair is not always conducted according to established custom, as nowadays the white man's whisky plays an important part in the celebration. This is totally at variance with the ancient custom as practised by the Indians a century ago, when the dancing and jollity did not commence until the fourth day.

In those days things were decidedly different and the affair was conducted with great ceremony. All offenses were forgiven on the occasion of this festival, which took place early in August instead of June, as it does now (perhaps on account of the country inhabited by the tribe being so much farther north and the corn ripening later). On the morning of the first day the medicine man. dressed 
with white leather moccasins and leggings and a white deerskin on his shoulders, went at daybreak to the center of the village and started a fire, which he did only after considerable difficulty, by rubbing two dry sticks together. Four young men then approached from the four corners of the square, each carrying an oak log. They advanced towards the fire with great ceremony, and deposited their $\log$ s end to end, pointed to the four points of the compass. After these $\log s$ had become well ignited four other young men came forward, each carrying an ear of new corn, which the medicine man took from them and placed upon the fire, where they were consumed. Then four other young men approached carrying a quantity of the " cassina " plant, from which the black drink is manufactured. Some of the leaves were placed on the fire and consumed, after which the remainder was immediately dried and cooked for use.

The warriors and other males of the tribe having assembled, they proceeded to drink the black drink in the usual manner. During the first day's ceremony no women were allowed to approach the fire, and it is a question whether they were allowed admittance on the second or third days. The third day was spent by the young men in hunting and fishing. On the fourth day the whole town assembled, including men, women, and children, and the game killed on the previous day was cooked and served for a great feast, and the day was spent in eating, drinking, and dancing. Large pots of sofkee were placed about and a wooden spoon was constantly at its side so that any one wishing to partake of it could do so. The method of making sofkee in the old days was to boil a quantity of pounded corn until it formed a soup of the consistency of rather thin gruel; to this was added a small quantity of lees made from ashes of hickory wood. The soup thus made kept for several days in covered pots. At the present time sofkee is made of boiled corn and hominy, without the addition of the lees made from hickory wood. The Indians squat about the kettle, each one drinking a spoonful of the mixture in turn, using the same large wooden spoon. 
The "black drink" was made from a shrub found in Georgia, and Carolina, and Northern Florida, which is called cassina. The leaves were collected and boiled over a fire : they were then poured from one pan to another until fermentation took place, when it was considered ready for use. In ancient times it was a custom of the Indians during this celebration to seat themselves in a circle around the fire, and three young men handed gourds full of the black drink to three of the greatest chiefs present. The young men then stepped back a few paces and uttered what was known as the black drink cry, first exclaiming loudly the word " choh." At this signal the three chiefs drank from the huge gourds, the young men uttering the wailing note, and the chiefs drank until the note ended. The gourds were then taken from the mouths of the warriors and the young men handed them to the chiefs next in rank, pronouncing the word " choh," but the cry of the black drink was not uttered, as none were entitled to this distinction except those highest in power. After drinking the concoction the warriors disgorged it, and we are told that it was considered praiseworthy to be able to do this gracefully.

The Indians are warned by their medicine men not to eat corn until after the celebration of the Green Corn Dance.

William Freeman, of Little River, who has lived near the Indians for many years, told me how, on one occasion, Dr. Tiger was at his house when he had green corn for dinner: it was some weeks before the Green Corn Dance was to take place, and Dr. Tiger looked wistfully at the corn and asked, "You eat green corn now?" Freeman answered, "Me like corn plenty now."

Tiger went on with his meal, but did not eat any corn, although he seemed troubled about something. At last he told Freeman that the Indians were warned by their medicine men not to eat green corn before the annual celebration, as it would make them ill; " Make Indian sick," as he expressed it.

It seems, according to Tiger's statement, that some of the squaws and children have eaten green corn before the dance, but the men never eat it. 
I am not certain that this is true, as I have been told by other Indians that they ate corn whenever it was ripe. I have asked many Indians about this, but they dislike being questioned regarding their customs, and one is never sure that they are telling the truth in such matters.

Freeman was under the impression that Dr. Tiger might take a nibble somewhat earlier than his comrades in future.

The new year commenced with the Creeks after the celebration of the green corn dance, or, at least, this was a custom when they inhabited Alabama and Georgia, as August was considered the first month of the year. At present it is doubtful if they have made any change in their yearly calendar, although the green corn dance takes place earlier. They divide their year into two seasons, summer and winter, and they then divide these into moons as follows : -

August . Heyothlucco . . Big Ripening Moon.

September . Otauwooskochee . Little Chestnut Moon.

October . Otauwooskolucco . Big Chestnut Moon.

November . Heewoolee . . . Falling Leaf Moon.

December . Thlaffolucco . . . Big Winter Moon.

January . Thlaffochosee . . Little Winter Moon, alias Big

Winter Moon's young brother.

February . Itootahlahassee . Windy Moon.

March . Tausautchoosee . Little Spring Moon.

April . Tausautcheelucco . Big Spring Moon.

May . Keehassee . . Mulberry Moon.

June . . Kochohassee . . Blackberry Moon.

July . Hoyeuchee . . . Little Ripening Moon.

\section{CLOTHING AND ORNAMENTS.}

THE costume of a Seminole Indian usually consists of a turban, a breech cloth, a calico shirt, and a neckerchief. This is the usual costume worn by them when in their own camp and among their own people : but when they risit the white man's town they add two 
or three cravats and sometinic pataloons as well, but as a rule they cover their legs with (........ leggings of their own manufacture. They also wear a chain and numerous safety pins fastened to their shirts, but I have n ver yet seen one carry a watch. Their turban is made of a wo shawl, sometimes covered with a piece of calico and even silk when hey wish to be particularly gorgeous in their attire. On one occasion I saw an Indian by the name of Billy Bowlegs wearing a turban encircled by a band of metal (probably tin). The older Indians usually wear a red woolen turban made by winding a shawl around their heads, which they fasten by tucking the ends skilfully awăy beneath the folds without the use of pins. As a rule they do not wear a turban when hunting. They sometimes wear moccasins in camp, and they al-

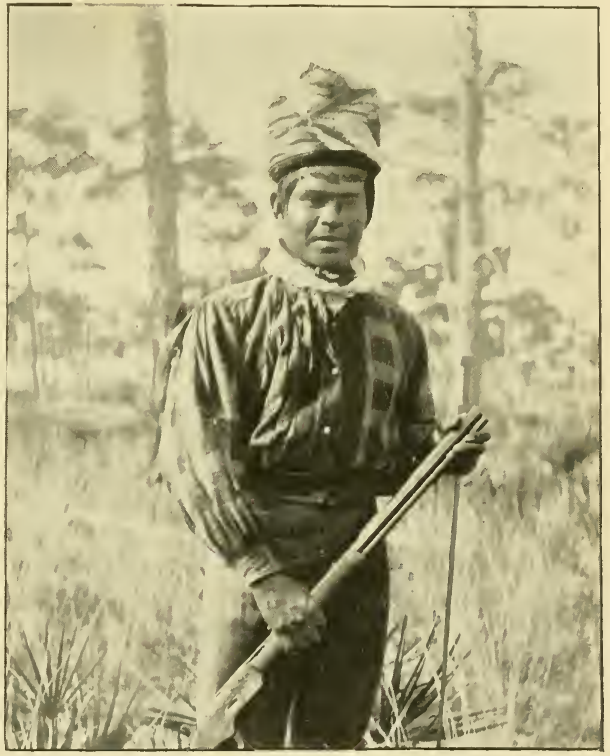

JACK CHARLIE. ways wear them when visiting a white man's town. They rarely wear any of the white man's clothing in their own camps, as the older Indians are prejudiced against having any of the younger ones associate with white people or adopt their customs.

The costume of the women consists of a cotton or calico skirt and 


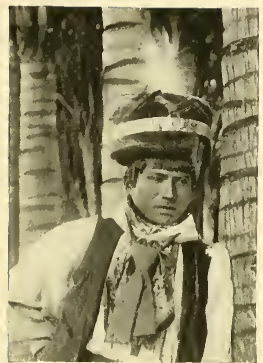

BILLY BOWIEGS.

waist. The waist merely reaches below the breast, leaving a portion of the stomach bare. In most cases these dresses are more or less ornamented by sewing on pieces of calico of different colors. The women do not wear moccasins. Young girls, up to the age of eight or nine years, wear only a skirt, being nude above the waist, while the boys wear a shirt only. Younger children go about naked in the camps, but at the present time they often put on little cotton shirts, if they happen to be in the ricinity of the white settlements. As soon as they get into camp, however, off come the clothes and the youngsters run about in a state of nature. Many of the men shave their heads, leaving only a scalp-lock and a little bang of hair on the forehead, but this custom is not always followed by the younger Indians.

The women wear great quantities of beads which they hang in string s about their necks, and the weight of these must be very great. The women also wear round pieces of silver made from dimes and quarters hammered very thin. These they fasten to the breast of

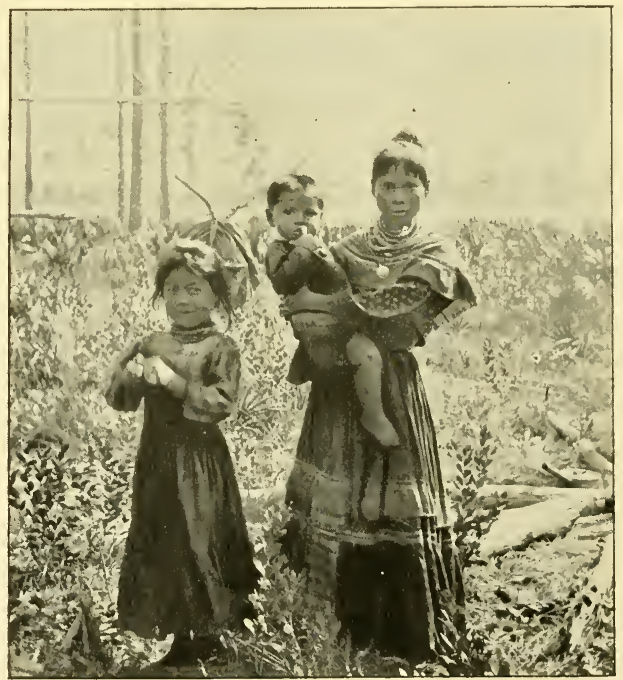


their dress. They also wear half dollars and dollars hung in the same manner, but those are not hammered. Occasionally, though rarely, they make very thin large discs of hammered silver, which are worn by the women over the breasts, one on each side. The men do not paint their faces, but occasionally wear ornaments when

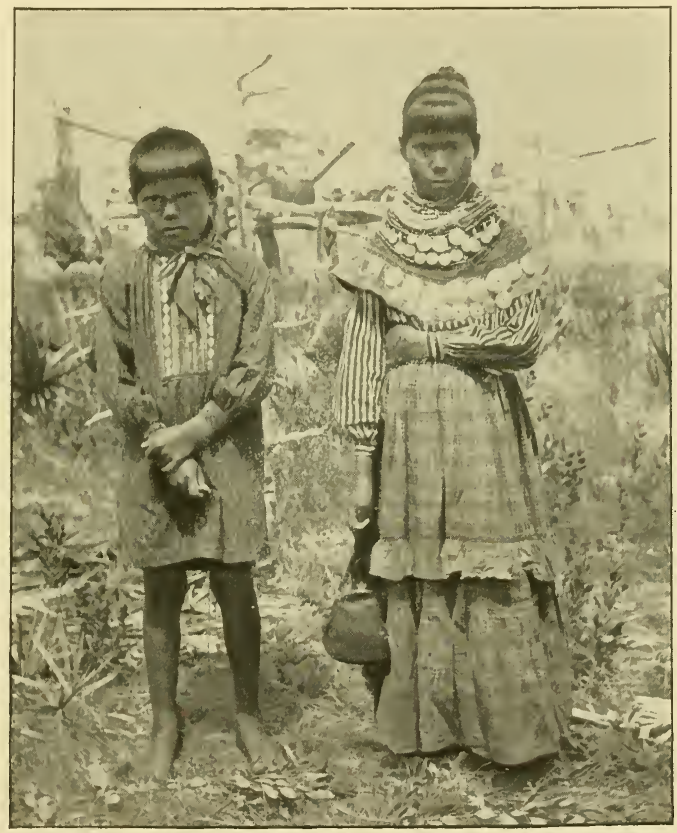

visiting a white man's camp or going to a town on a trading expedition. I am told they sometimes paint their faces during the ceremony of the Green Corn Dance, but was unable to get any definite information on this subject. Sometimes the men wear bracelets of silver, but it is not a very common custom, as I have never seen but 
one Indian adorned in this manner. It is probable that most of their ornaments are kept in safe places to be used only on "state occasions."

\section{METHODS OF HUNTING.}

DURING the spring the manatees enter the rivers to feed on the "manatee" grass, and, as some writers claim, the leaves of the mangrove trees. They are abundant in the bays and rivers all along

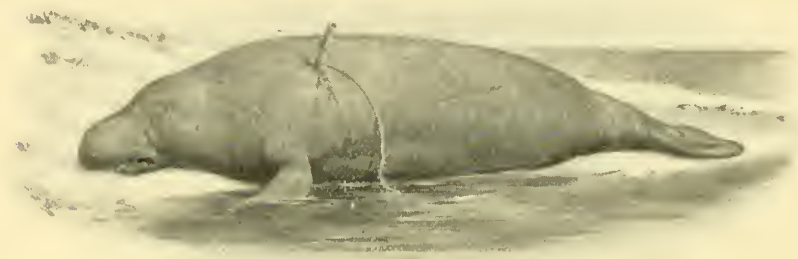

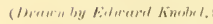

M.N. ITEE.

the west and east coasts of Southern Florida. At one time the st. Lucie River was a noted place for them. In New River the manatee is still common, and they are numerous at times in the lower part of Biscalyne Bay and on the west coast south of Charlotte IJarbor. They live equally in salt or fresh water, and while with the Indians on one of their manatee hunts I have seen half a dozen rising to the surface of the ocean at one time, over a quarter of a mile from shore.

Many of these animals are killed by the Indians every year. They hunt them in canoes, sometimes in the rivers, and again in the ocean, but usually near the mouth of some river.

These animals come to the surface every few minutes to breathe, and their heads may be seen as they appear for a moment above the surface of the water. 
I have often accompanied Osceola and other Indians on a manatee hunt of this kind. They harpoon them as they rise to the surface, using a steel point barbed on one sicle, attached to the end of a long pole. To the steel point is fastened a strong cord, which in turn is attached to a float. Upon being struck the manatee sinks at once, but the direction in which he moves is indicated by the float. The

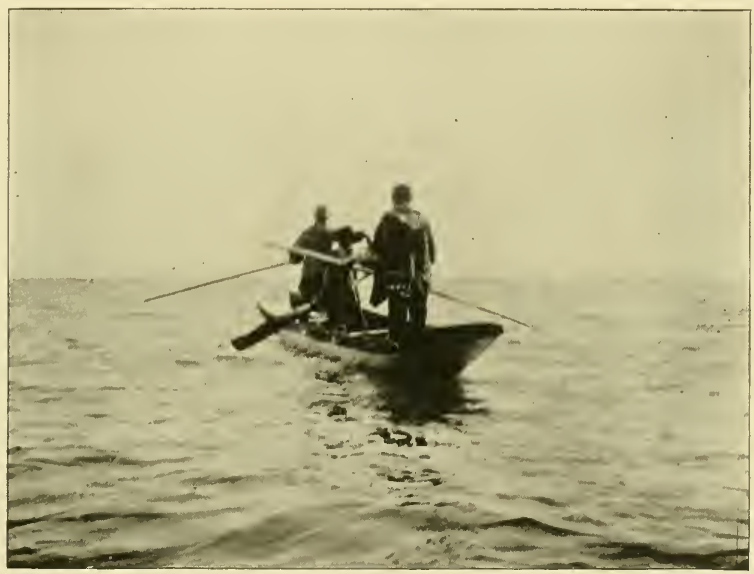

AFTER MANATEE.

Indians follow the float as closely as possible and watch for him to rise to the surface, when they shoot him through the head, and the huge animal is then towed to the shore. It requires considerable skill as well as strength to drive the harpoon through the thick, tough hide. Many of these animals grow to a very large size, and it is claimed that some of them have been taken which exceeded twelve feet in length.

One day, while talking with Old Charlie and his squaw at his camp on the north bank of New River, he drew my attention to a long brown object which was moving slowly up the stream a few 
inches beneath the surface of the water. It was about twenty feet from the bank, and Old Charlie whispered to me that it was a manatee. Getting into my canoe I paddled gently after him, but as I did so an exclamation from Old Charlie caused me to turn, and there, just below me, was another manatee larger than the first. I whispered to Pat to keep the boat as still as possible, and in another moment the huge creature passed directly under us, not two feet beneath the surface, and so clear was the water that the coarse hairs on his brown skin were distinctly

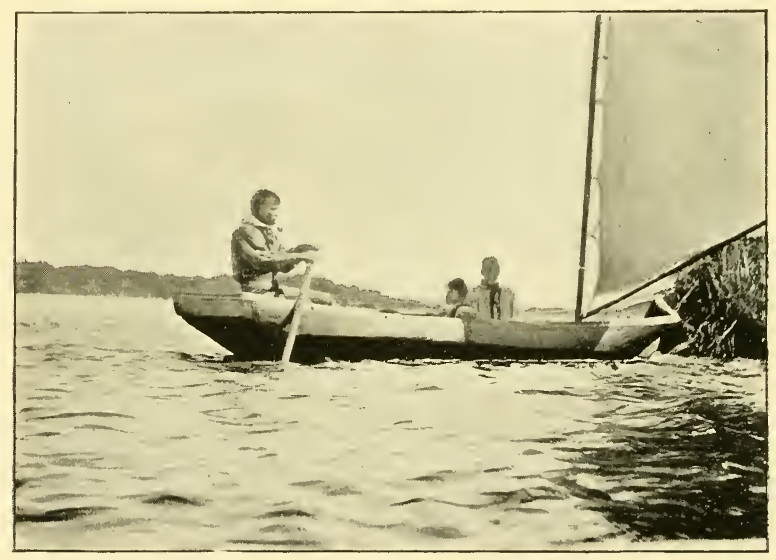

visible. He appeared to be at least ten feet long, and, although I wanted that particular manatee very much, as I had no harpoon in the boat, I could only sit and watch him slowly move up the river, where he undoubtedly joined his companion who had preceded him.

The Indians are very fond of the flesh of this animal, which somewhat resembles coarse beef, and what they do not use themselves they readily sell to the white settlers.

The manatee is a very timid creature, and the least sound, such 
as an oar striking against the side of the boat will cause him to sink and swim away at once.

The Indians kill a great many alligators for the purpose of selling their skins to traders. As a rule, they "fire-hunt" them at night. The alligator lying with his eyes out of the water does not appear to be afraid of the light which is reflected in his eye, having the appearance of a brilliant candle flame, and may be seen

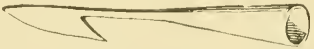

HIARPOON. from a considerable distance. The Indian paddling in his canoe approaches within a few feet of the animal and easily shoots him through the head, after which he is speared and towed to the shore.

Of late years alligators have become comparatively scarce and it no longer pays professional hunters to kill them as a business, although they are still numerous in many places in the interior. Indians, as a rule, do not like to hunt far from their canoes or ponies, although they are good walkers, and, if occasion requires, will cover long distances on foot.

The Indians are very fond of bear meat and extract an oil from the fat which they prize highly. Whenever a bear is discovered a hunting party is immediately organized and the animal is tracked to his hiding place, surrnunded and killed.

When deer hunting the Indians divide into small parties, two or three bucks hunting together, taking with them their squaws and children. They select a part of the country where deer are known to be.plenty and usually succeed in killing a great many. When in the vicinity of a white settlement they find a ready market for their venison and what they do not sell is smoked and dried for future use: dried venison will keep very well, but it is tough and unpalatable.

During the planting season both the men and women work in the field, but when on a hunting expedition the women do all the camp work. The men, when not hunting, lie about the camp taking it easy. Upon reaching a new camping place the men take their rifles 
and immediately go off hunting while the squaws are preparing the camp.

They hunt in the morning and evening, returning to camp before noon unless they have been unsuccessful in finding game, when they sometimes tramp about the woods all day.

On these hunting excursions he wears nothing but a cotton shirt unless it is a very rough country, when he sometimes wears leggings made of soft leather. He rarely wears his turban except in the very hottest weather.

The Indians are very skilful hunters, although they seldom use dogs, in spite of the fact that they always have a lot of curs about their camps. They hunt deer in the manner known as "still hunting," walking about the woods morning and evening. moving cautiously and silently through the underbrush in a manner peculiar to a ghost or an Indian, constantly peering about in all directions for the deer, which they hope to find feeding. Very few white men are able to kill deer successfully by still hunting, ret the Indian rarely hunts in any other way. Trained in woodcraft from childhood, he moves slowly along, stopping every few yards to look about, raising his head slowly and cautiously above some clump of bushes. His eye being trained for such work, he is able to see game in places where it would be practically invisible to the eye of the ordinary hunter.

When trailing a bear or a panther an Indian can often follow the track without difficulty in places where a person not used to the woods would be unable to distinguish any mark whatever. One of the difficulties experienced by non-professional hunters is to distinguish between a freshly made track and one two or three days old. In damp sand and in shaded places where the sun's rays do not penetrate this is often very difficult to do. An animal walking on sandy land when it is damp with dew will press small straws and sticks into it, which, when they rise again, carry with them numerous particles of damp sand which will still adhere to them when dry. This, of course, is an almost positive indication that the track has been made after the dew had fallen; but when the track is made in shady places and the 
ground remains damp for a week at a time even professional hunters will sometimes be at fault.

The Indians burn the country every spring in a most reckless manner, destroying great quantities of timber. They set the dry grass on fire, so that, by destroying the old grass, the new, fresh shoots coming up attract the deer and turkeys which are generally found on such places. Besides this, the ground being burned off renders still-hunting much more easy, for the game can then be so much more readily seen. The Indians are splendid hunters, but few of them can beat a white man shooting at a mark.

I have seen Osceola kill a deer while rumning at full speed, nearly a hundred yards distant: I have also seen him drop two deer, one after the other, before the second one had time to run, and on another occasion I saw him miss a fox-squirrel on the top of a tree three times in succession.

Wolves are not uncommon in the southwestern portion of Florida, from the Big Cypress Swamp southward. Osceola (Gart-sum-a-tele-kee) told me that last year he found an old female wolf with two cubs a little way south of his camp on the Big Cypress. Both cubs, as well as the old one, were black. He shot the mother, which he claimed growled and acted very much as a dog would do. He caught the young cubs alive and carried them to camp, but they would eat nothing, and after two or three days he killed them; as he described it, " Me bang um heads against a tree."

Old Charlie, whose name is Barfotartso, told me that he had heard of large bears beyond the Big Cypress. He said, "One white man he tell me see big bear, white on breast," but that he had never seen one himself, and he did not know if the story were true. He also told me of a large bat which occurs in Florida, and which, judging from his description, was a species not yet recorded from the State, and which would probably spread two feet or more. He also told me of a black panther which had been killed by the Indians some years ago. In all probability this was nothing more than a melanistic example of the common form.

Old Charlie spoke of some very large alligators which he had seen, 
but said, ". They all gone." According to his statement, when he was a boy game was very abundant in the country about the Cypress. Creek and Hillsboro River. Bears were numerous at that time, but nowadays it is rare to find one in that country. Deer are still abundant, but Old Charlie says they are much less so than formerly.

In the Big Cypress Swamp and in some localities near Lake Okeechobee paroquets are numerous. I have seen flocks near Cypress Creek, and killed a number of specimens last winter near snook Creek. At one time they were abundant on the Kissimmee River, but are so no longer. Paroquets build their nest in holes in trees, as a rule, and the Indians wait till the young are half grown, and then, during the absence of the old birds, they cut the tree nearly through : the next night, watching their chance, they fell the tree quickly with one or two blows of the axe and catch the birds in the hole before they have time to escape.

\section{LOCATION OF VILLAGES.}

THERE are five principal settlements of Florida Indians. These are situated, (I) in the Big Cypress, southwest of Okeechobee, (2)

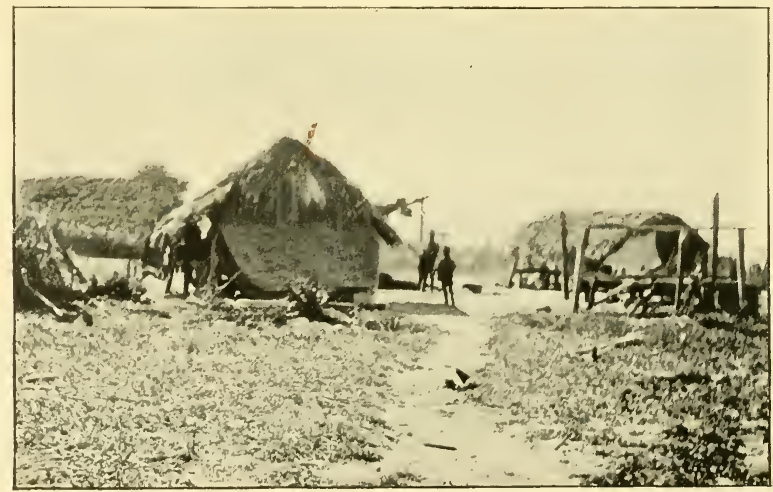

INDIAN CAMP, NEW RIVER. 
near Miami River, (3) on Fish Eating Creek, northwest of Lake Okeechobee, $(t)$ on Cow Creek, northeast of Okeechobee, and (5) at Cat Fish Lake. There are a number of families who have temporary camps in other localities, and some few Indians have what they call their permanent camps outside of these villages, there being, I am told, several Indians living on the islands in

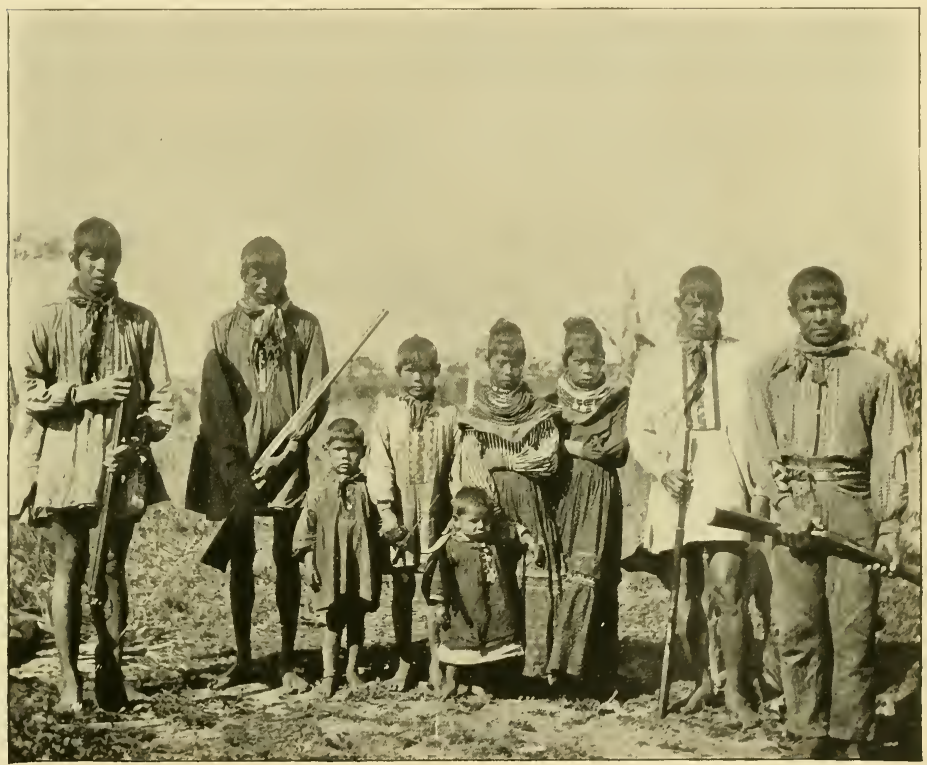

the Everglades, and four or five families have camps on New River; but nearly all of these have camps elsewhere as well. The number of Seminole Indians in Florida is variously estimated as from 250 to 350 , and it is possible they may exceed that number. Many of the Okeechobee Indians are descendants of the Creeks or Muskogees, as the language spoken there seems to be of that 
tribe. The language spoken by the Miami Indians is somewhat different.

The chief seat of government is located at Fish Eating Creek, and at this camp resides Hospataki and Tustanugge, who are chiefs of note, although, as I understand it, there has been no regularly recognized head chief among the Seminole Indians since the death of Tiger Tail. It was customary in the old days to have the chieftainship descend in the female line, but this is not so at present, and if a chief is now elected it is done by the council.

\section{SEMINOLE HISTORY.}

THERE is a tradition handed down from one generation to another among the Indians to the effect that a very long time ago some wandering bands of Indians came from the northwest, and, finding the country fertile and filled with game, they settled in the country of the then powerful tribes of Florida and Appalachian Indians. They were received in a friendly manner and for many years lived on good terms with their neighbors, but later, when their numbers had increased, they made war upon the Appalachians and succeeded in destroying that tribe early in the eighteenth century. These Indians, who belonged to the Creek or Muskogee tribe, became famous for their warlike abilities. They extended west to the Alabama River, and east throughout Georgia and Northern Florida. They conquered the Alabama nation who inhabited the country near the Alabama River: but later restored to them their lands upon the Alabamians becoming a part of the Creek nation.

At this time various wandering bands settled in Florida, most of them being descendants of the Creeks or Muskogees. These were known as Seminoles or "lost men." The Indians now known as Seminoles in Florida are principally descendants of the Muskogee or Creek nation, but there are a few individuals descended from the Mickasaukies, Uchees, and Choctaws.

In the year I 835 commenced what is known as the Seminole War. In the year $\mathrm{I}_{32} 2$ a treaty had been made with the Creeks or Semi- 
noles (at Banes' Landing on the Ochlawaha) by which they ceded their lands which they held in Florida in consideration of the payment to them of an annuity of $\$ \mathrm{I}_{5},+00$, and they agreed to send a delegation of chiefs to see the country offered them west of the Mississippi River to which they had agreed to emigrate. It was stipulated in the treaty that the cost of emigration should be paid for by the United States. All cattle owned by the Indians were to be estimated and paid for, and provision made that each person on reaching the new location should receive a blanket, a homespun frock, and an additional annuity of three hundred dollars per year for fifteen years was to be divided among them, besides other minor considerations, such as claims for runaway slaves, and the services of a blacksmith, etc.

It was agreed that they were to remove within three years. The Seminoles living north of the boundary line (designated by Camp Moultrie) began to move west, and a few bands continued to emigrate until 1835 , when the balance refused positively to go at all.

This year marked the commencement of what is known as the Seminole War. The Indians burned a bridge within six miles of Fort Brook, on Tampa Bay, and killed a mail-carrier in August of that year. Charles Emathla, an Indian chief, who was one of those friendly to the emigration movement, had been killed, and chiefs Little Cloud and Alligator, with their bands, attacked and nearly destroyed Major Dade's company at a place about fifty-fire miles south of Tampa Bay, Major Dade being among the killed. The party consisted of II + men, II 2 of whom were killed. It was at this time that Osceola first became prominent in directing the movements of the Indians.

Robert Osceola and Charlie Osceola (of the Big Cypress) are descendants of that celebrated chief. Some of the old Indians are still alive who took part in that war. In speaking to Old Charlie (not Charlie Osceola) about Osceola he did not know at first who I meant, but upon my asking him if he had heard of Powell he immediately answered, "Uncar; me know, great man."

The older Indians believe to this day that General Harney granted 
them the Everglades to live in forever, and they do not feel kindly towards the white men who are gradually penetrating further and further into what they consider to be their domain.

The names of the following war chiefs, of whom I have given a brief biography, are remembered by many of the present generation of Florida Indians.

OSCEOLA, war chief of the Seminole tribe. He was born about the year I803, and was the son of an English trader named Powell, his mother being a daughter of a Seminole chief. He was also called Assini Yahola and Powell, which was the surname of the white man who married his mother. Osceola signifies the rising sun. The grandfather of Osceola was a Scotchman who married a Creek woman; his father, therefore, was a half-breed, but his mother was a Creek woman of pure blood. He was born on the Tallapoosa River between the years 1800 and 1806 . He was noted as a ball-player and hunter and for running and wrestling. At the time of the Seminole War he was not as great a chief as Jumper, Holata Mico, or Coa Hajo, or Holato Mico, or Red Stick, but rose to prominence during the Indian hostilities. Osceola soon became one of the leading chiefs on account of his activity and success in the Indian War. He had two wives, both of them young. It is claimed he was taken prisoner at last by treachery while holding a conference under a flag of truce, and died of inflammation of the throat in 1838 , while confined at Sullivan's Island as a prisoner of war.

NEAMATHLA was by birth a Creek, and was at one time the most distinguished chief in the Seminole tribe. Neamathla returned to the Creeks about the year I826, and sat in council with them in 1827. Foke Luste Hajo was at that time one of the principal Florida chiefs. He was one of the seven who was appointed to visit and explore the country offered to the Seminoles west of the Mississippi. His associates were Holata Amathla, Jumper, Charlie Amathla, Coa Hajo Arpiucki, and Yaha Hajo. He was friendly to the whites, and in 1835 , at the declaration of war, he was warned to leave the country by the other Indians. Hola Amathla, Otulke 
Amathla, Foke Luste Hajo, Conhathee Mico, and Foshutchee Mico fled to Fort Brook and encamped under the protection of the guns.

CIITTEE YOHOLO, a Seminole chief of note. He was a young man at the time of the seminole War, but, being a venturesome warrior, he soon rose to prominence and received honors from his tribe. He was given several names. After killing his first white man he was called Chewasty Emathla. After he had killed several white men and received several names in succession he was christened Olocta Tustennugge. He afterwards emigrated to Arkansas.

\section{LANGUAGE.}

The two principal languages spoken by the Indians now resident in Florida are known as Okeechobee and Miami. They are quite different, although many of the Indians speak both languages. That spoken by Robert Osceola, Old Charlie, Tom Tiger, and the other New River Indians is the Okeechobee dialect, and is undoubtedly modified Creek or Muskogee. I was unable to learn what language is spoken by the Miami Indians, but it is quite different. The majority of the words which I have included in the following vocabulary have been obtained through conversations with Robert Osceola (Gart-sum-a-tel-e-kee) and other Indians with whom I have hunted.

\section{VOCABULARY.}

\begin{tabular}{|c|c|c|c|c|}
\hline An Indian & & . & & Estee-sar-tsee. \\
\hline White mas & & - & & Estee-hat-kee. \\
\hline Negro & & . & & Estee-lustee. \\
\hline Man. & & . & & Estee. \\
\hline Woman & & . & & Hock-tee. \\
\hline Child . & & . & & Es-to-chee. \\
\hline Scalp. & & . & & E-kah-hal-pee. \\
\hline Tooth & & - & & Nut-tee. \\
\hline Hand. & & . & & In-kee. \\
\hline Leg . & & . & & Hats-ka-wah. \\
\hline
\end{tabular}


Foot . . . . . E-lee.

Stomach . . . . . Im-pas-sah.

Town . . . . . To-lo-fa.

Chief . . . Nicco; or See-a-pah-ya.

Warrior . . . . Tus-ka-nuk-kee hib-otskee.

Friend . . . . . His-see.

Enemy . . . . . Ho-thlee.

Kettle . . . . Alk-us-wah.

Ax . . . . . Pa-chos-wah.

Hatchet . . . . Po-chos-wo-chee.

Gun . . . . . Klack-o-push-kee-mifsea; also Aytsah.

Rifle . . . . . I-oke-finegay; also aytsah-sa-tahhee.

Knife . . . . . Slof-ka.

Boat . . . . . Pith-lo.

Paddle . . . . . Is-kahf-ko-chee.

Legging . . . . Huf-fa-tick-ka.

Coat . . . . . Ai-o-kof-kee-tah.

Shirt . . . . Ai-o-kof-ke-ko-chockonnee.

Headdress . . . . E-ka-sim-enah-hits-ka.

Moccasin . . . Ist-e-lee-pik-kah.

Tobacco pipe . . . E-chee-pok-wah.

Tobacco . . . . . E-chee.

Beads . . . . . Lo-nup.

White beads . . . Lo-nup-hat-kee.

Sun . . . . . Hassee.

Night . . . . . Nith-lee.

Morning . . . . Hat-ah-yat-kee.

Summer . . . . . Mis-kee.

Winter . . . . Thla-fo.

Wind . . . . . Ho-tallee.

Rain . . . . . Os-kay.

Fire . . . . Tot-ka; or Toad-ka.

Water . . . . O-ee-wah. 
Sea . . . . We-hat-ka.

Lake . . . . . Ok-hassee.

River . . . . Hatchee thlokko.

Creek . . . . . Hatch-oochee.

Bog . . . . . . Ok-lee-ivah-hee.

Island . . . . . O-tee.

Silver . . . . Chat-to-ko-na-wah.

Copper . . . . . Chat-to-ko-na-wah-lah-nee.

Egg . . . . . . Its-hoos-tar-gay.

Corn . . . . . Chee.

Soup. . . . . Sofkee.

Potato . . . . Ah-hah.

Squash . . . . Ta-hai-ah.

Tree . . . . . E-to.

Log . . . . . . E-to-wah-kee.

Pine . . . . . . Choo-lee.

Oak . . . . . Lok-tsa-sum-pa.

Grass . . . . . Pah-pee.

Bread . . . . . Tuck-lai-kee : also Mb-bas-wah.

Meat . . . . . A-pess-wah.

Beaver . . . . Ets-hass-wah.

Deer . . . . . . E-cho.

Bear . . . . . No-ko-see.

Otter . . . . O-sa-na.

Alligator . . . . Hal-pa-tah.

Fox . . . . Tso-la.

Wolf. . . . . Ya-ha.

$\operatorname{Dog}$. . . . . . E-fah.

Squirrel . . . . E-thlo.

Rabbit . . . . Cho-fee.

Wildcat . . . . Ko-ak-o-chee.

Panther . . . . Cat-sa.

Raccoon . . . . Wood-ko.

Opossum . . . . Sok-athat-kee.

Hog . . . . . . Sok-a. 


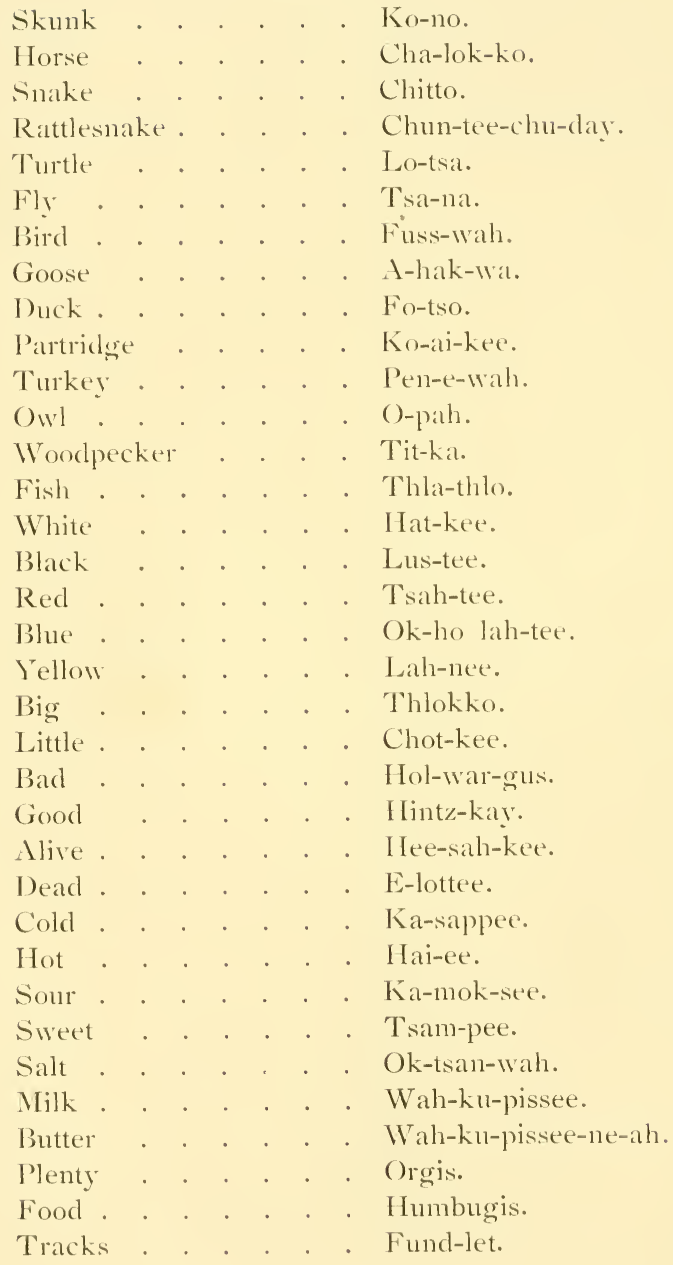


Many . . . . . Yo-mee-chen.

You are . . . . . To-yits-kist.

He is . . . . . To yits.

I . . . . . . Annee.

I want . . . . . Si-arts-jay.

He . . . . . E-mee.

Near . . . . . A-wo-lee.

Far away . . . . Ho-pai-ee.

To-day . . . . . Motz-en-etar.

To-morrow . . . . Pok-see.

Yesterday . . . . Pok-san-gee.

Yes . . . . . Un-car.

No . . . . . Hick-ast-chee.

To sing . . . . Ya-hai-kee-tah.

To dance . . . . O-pan-kee-tah.

To kill . . . . . E-leech-ee-tah.

Go. . . . . . Hiepus.

Gone . . . . . Cir-cus-jay.

Good-night . . . Hiepa-larnis-jay.

Have you any . . . Chey-mo-char.

Can you speak the Indian language . . . . O-por-nar-gart-g-gate the-tare.

What is the price . . In-nar-car-poor.

Which way . . . . Ist-ah-mar-mar-hen.

See it . . . . . In-e-gits-kar.

See . . . . . E-gits-kar.

What do you call it . Nack-key-tay.

I Klamen.

2 Tookelin.

3 Toceenin.

4 She-larkin.

5 Sarkepin.

6 Eparkin.

7 Colorparkin.

8 Senarparkin. 
9 Osther-parkin.

Io Parlin.

To illustrate the difference between the Creek language and that spoken by some of the "Miami" Indians, I give a few words selected from a list obtained through the kindness of Miss Freeman, the daughter of Mr. William Freeman, of Little River.

I Hump-kee.

2 Po-coo-lee.

3 To-chee-nee.

+ Osteen.

5 Cha-kee-pin.

6 Ee-pa-kin.

7 Co-la-pa-kin.

8 To-chee-nee-pa-kin.

9 Osteen-parkin.

io Po-lee.

\begin{tabular}{|c|c|c|c|c|c|c|c|}
\hline Horse . & . & - & - & - & - & - & Co-i-yee. \\
\hline Raccoon & . & . & . & . & . & . & Su-a-wee. \\
\hline Turkey & . & . & . & - & - & . & Fi-tee. \\
\hline Cow . & • & . & - & - & - & - & Wau-kee. \\
\hline Shirt & . & . & . & . & . & - & Fo-kee-shee-ca. \\
\hline Dress & - & . & - & - & & & O-ho-nee. \\
\hline Rabbit . & . & . & . & . & . & ${ }^{\circ}$ & Cha-co-fee. \\
\hline Otter . & . & . & . & . & - & • & O-shy-nee. \\
\hline Wolf . & . & . & . & . & 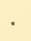 & & O-ba-ho-shee. \\
\hline Wildcat & . & . & . & 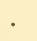 & 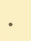 & 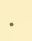 & Coo-on-o-shee. \\
\hline Man . & & . & 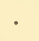 & & & & Na-co-nee. \\
\hline Panther & . & . & . & . & . & . & - Coo-ot-cho-bee. \\
\hline
\end{tabular}




\section{THE FLORIDA PANTHER.}

The Florida Panther is still not uncommon in the more unsettled portions of the State. It is somewhat smaller and more rufous in color than its Northern brethren, and its feet are smaller in proportion to the size of the animal. It is comparatively shy and is difficult to find on account of its habit of continually wandering about, rarely staying long in one place unless attracted there by an unusual

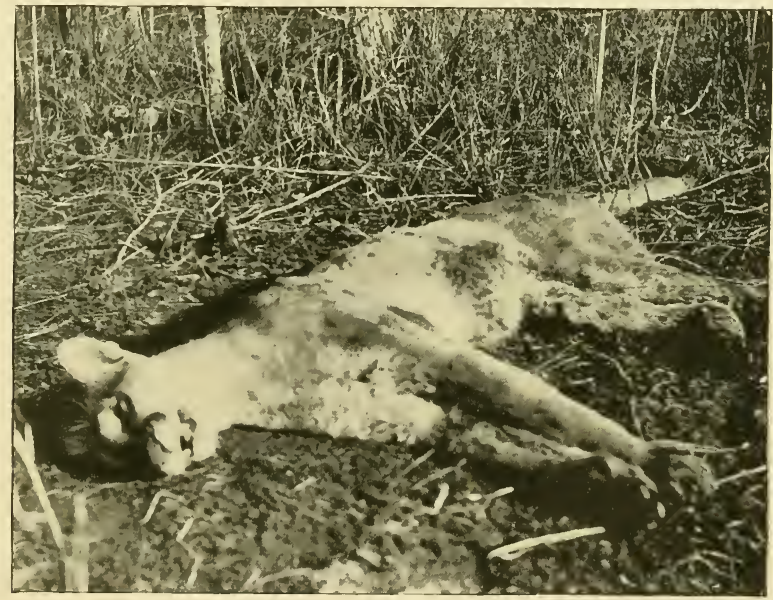

FLORIDA PANTHER.

abundance of tood, such as in the vicinity of a hog camp or where deer are very plenty; but as a rule they move about a great deal. often traveling twenty miles or more in a night. The Florida Panther preys upon small animals and is very fond of deer and dogs 
when it can catch them. They hunt as a rule at night; but on cool and cloudy days or after a rain they often move about in the daytime. If a panther kills a deer he returns to it the second night, but rarely the third night, and much of the animal is often left uneaten. In the old days it was by no means uncommon to find a dead deer in the woods with the evidence about it of having been killed and partly eaten by a panther.

The track made by a panther somewhat resembles that of a hound, but it is larger, and the ball of the foot is relatively much larger: the toe marks are in front and do not show any mark of a claw unless the animal is jumping.

We found the fresh trails of seven panthers in one week within thirty miles of Lake Worth. The soft foot of this great cat leaves very little trail except in mud or soft sand. In traveling over a piece of sandy soil the tracks are almost invisible where those of a dog can be plainly seen.

It was our usual custom to start out at daylight and allow the hounds to run about as they pleased as we rode slowly through the woods. Every few minutes a hound would start off on a fresh trail of some animal, and we would have to call in the other dogs and "slow trail" it until we came to a place where the ground was clear and soft enough for us to see the tracks and learn what it was they were after. Oftentimes it would be a deer or cat, and we could sometimes tell what it was by watching the actions of the dog. If the trail was very winding and wandered in and out through a piece of scrub, turning this way and that, we were pretty certain it was not a panther, for they usually follow a straight course, turning but little from right to left.

In crossing a piece of open land, a panther walks directly across, while a deer would make a more or less irregular trail. Then again, if a hound following a trail smells along the top of an old $\log$, we know very well that it is not a deer that has walked along the log, but either a wildcat or a panther.

Of course if we found it was not a panther which the dogs were trailing we called them off and again continued our search. About 
eleven oclock we usually returned to camp. Later than that, unless the clay was cloudy, no dog could follow a trail on sandy soil in the hot, dry weather of Southern Florida. Sometimes the panther would make a trail late in the morning, and then of course it could be followed until afternoon, but usually the trails were made early at night. and became too " cold" to be followed after the sun had been shining on them for several hours. It was easy enough to follow through the grass where the ground was still moist, but upon coming out upon high, sandy, spruce ridges the hounds would lose the scent and wander aimlessly about trying to recover it.

In such cases we could sometimes assist them where the tracks were cliscernible in the soft sand, but in many

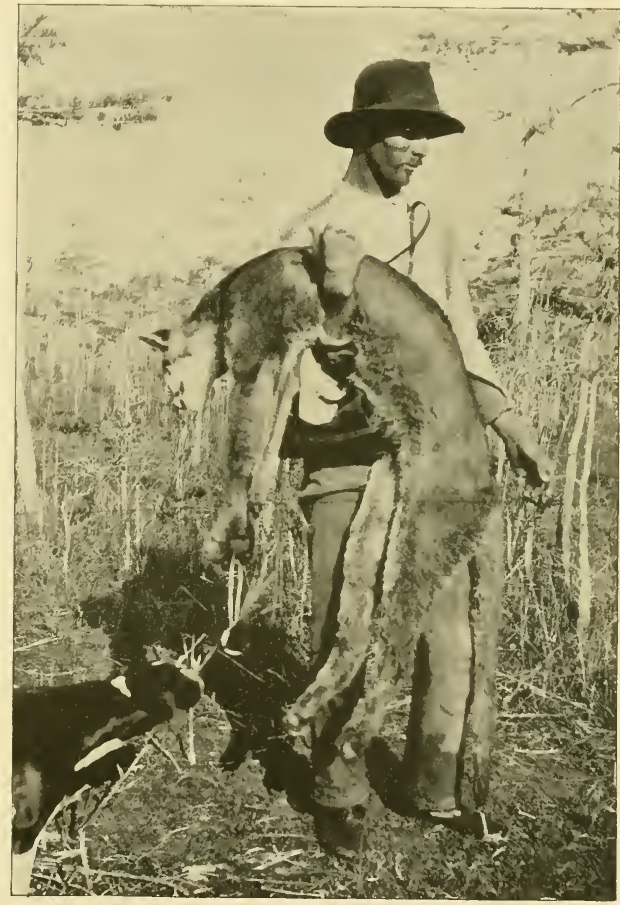

JOHN DAYIS.

places the ground was just hard enough so that it was impossible to see signs of the trail except at long intervals, and the time occupied in attempting to follow it across one of those 
dry places usually delayed us until too late to continue the hunt. A panther when " jumped" by the hounds usually runs but a short clistance, and then climbs a tree, and in such cases may be easily killed by the hunter : but sometimes the panther does not take to a tree, but conceals himself in thick undergrowth, and there it is more difficult to get at him and he is sometimes ugly.

Panthers will rarely attack a man unless wounded or with cubs, but they will fight the dogs, which have little chance against their teeth and claws. One particular panther which I killed in the spring of I 895 was quite ugly, charging the dogs savagely whenever they approached her.

Panthers are not uncommon in the wilder portion of the State, both on the east and west coast. The Indians report them numerous in the vicinity of the Big Cypress south of Fort Myers. During the winter of 1895 they were quite numerous near the cypress swamps about Long Hammock and Custard Apple Hammock and southwest of Lake Worth. John Davis killed six in one season. They are scarce now on the peninsula east of the Indian River, but were common there a few years ago. In I892 I saw the fresh tracks of a large panther near Canaveral, and back in the "eighties" Mr. O. A. Quarterman killed several in the ricinity of Canaveral, once making a double shot at two old males that he discovered fighting on the bank of Banana Creek. They vary much in size. Florida Panthers which will measure ten feet in length are exceedingly rare, and from what I am told by the hunters and Indians I am inclined to believe that a panther nine feet in length may be considered a big one in Florida. A good-sized male will weigh between one hundred and one hundred and twenty-five pounds, and I have seen fullgrown panthers (females) which weighed less than eighty-five pounds.

\section{A PANTIER HUNT.}

I wAs awakened before daybreak, and after dressing myself and eating a light breakfast we were in the saddle and well away from camp before it was light enough to follow a trail. The grass and 
bushes were dripping with dew, and an energetic but somewhat dissipated chuck-will's-widow was whistling away with much fervor. A moment later and a crow cawed from the top of a small pine, and then the full avian orchestra commenced in earnest, and the belated chuck-will's-widow was heard no more.

The dogs, eager to find a trail, were running in and out of the thick bushes, occasionally starting off on the trail of a deer or wildcat, upon which they were immediately called back by Davis.

Soon the sun rose, and then the bird music gradually ceased, although the bluebirds piped away alone for some time, occasionally assisted by a crow. At times the dogs would strike a trail on hard ground where we could see nothing. We would then have to call them in and "slow trail" it until we came to a place where the ground was soft enough to enable us to see the tracks.

Usually it proved to be a deer, sometimes a cat, but we were not after deer and cats, except of a larger kind, so the dogs were called off and we kept on. Panther tracks two or three days old were not uncommon, but no "fresh" ones were found, and I began to think we should have to give it up and return to camp. Once or twice the dogs sniffed along the top of a fallen tree, and our spirits immediately rose, as we knew that in all probability the animal that walked there was either a cat or a panther, but in every instance a further investigation proved it to have been the former.

At times each of us would take a hound and hunt in different directions, meeting later at some point agreed upon, and then again we would hunt all the dogs together. In this way we covered a great deal of ground.

At last "Cleve" started off on an apparently fresh trail and was immediately followed by the other dogs. Daris called him back and made him go slowly until he came to a piece of soft sand where the trail was plain and clear, and which this time proved to be that of a large panther, and was evidently quite " fresh." At this time I was not with them, so Davis and Gale started on to follow the animal alone. The dogs "jumped" him within a mile of where they struck the trail, and the animal ran for perhaps a quarter of a 
mile before taking to a tree. When Davis came up he saw the panther about twenty feet from the ground, standing upon a small limb, hardly large enough to support it, and looking about in an uneasy manner. Just above the panther was a larger limb where she could rest secure if she would take the trouble to mount a few feet higher, but instead of doing this she continued looking anxiously about, and as Davis approached was evidently making up her mind to leave the tree. Davis, knowing that I was particularly anxious to obtain a photograph of a panther, and as the tree was in an exposed and sunny place, immediately conceived the idea that if he should wound the hind legs of the animal with a small shot the panther would probably go higher up the tree and sun herself there until I should arrive. The result of this experiment was not a grand success, for upon receiving the charge of shot in her hind feet the panther immediately sprang (according to Davis statement) at least forty feet from the tree and ran with all the dogs after her into the cypress swamp, where she turned and attacked the dogs savagely, uttering in the meantime the loudest roars for an animal of its size that Davis had ever heard. The place where the panther concealed itself was about two hundred yards into the thick cypress swamp, where the ground was soft and wet. So, leaving Gale to follow with the dogs if the panther made a fresh start, Davis came back for me.

When I reached the spot and saw the place in which the animal had concealed herself, I was satisfied it was useless to attempt to try to photograph this one, so, leaving the camera with Davis, I took my rifle and pushed my way slowly into the swamp where I could hear the dogs barking furiously, and Doc's voice was soon added to the chorus. As I neared them I heard the panther snarling and growling savagely, occasionally making short rushes through the underbrush, evidently charging a dog. Suddenly she started off and ran perhaps one hundred or one hundred and fifty yards still further into the swamp. where the ground was more marshy and the undergrowth still more dense. It was impossible to see more than ten or fifteen yards in any direction through the thick undergrowth, and in some 
places it was necessary to cut the thom vines at almost every step. Slowly pushing my way in, listening to the dogs, especially to the shrill, high piping of Doc, who uttered almost a continuous howl whenever the panther moved, I approached within twelve or fifteen yards of where the animal was concealed.

Stepping cautiously over the logs and peering about me at every possible place where I thought she might be, I located her pretty definitely by the actions of the hounds which were now close to me, moving about from place to place, but all gazing in the direction of a thick clump of ferns and bushes surrounding an immense fallen cypress. Cautiously moving to one side, I saw the panther crouching beside and partly under the fallen tree. She was not over twenty feet distant, and as she turned her snarling face towards me she presented one of the ugliest pictures I have ever seen. Her ears were drawn tightly back and she exposed a splendid set of teeth. A rery pungent, musty odor ivas perceptible. As she turned towards me all the dogs sprang at her at once. Even gentle little Doc threw himself bravely into the fray, and crippled Cleve jumped at her as gamely as ever. She turned on them with a quickness that was astonishing, uttering a snarling roar while biting and clawing at them saragely ; but just then I fired, once, twice, three times, as fast as I could work the lever, and the great cat lay kicking and aimlessly biting, as the dogs worried her and fastened their teeth in her tough hide, while I cheered them on, and praised them, and told them what good dogs they were. Poor

- Cleve laid himself down close to the panther and commenced licking his foreleg, in which the bone was badly crushed. Bruce showed a long cut on his flank, and little Doc was scratched about the neck; luckily, none of the wounds were serious, although Cleve was laid up for some time. This was Doc's first panther and he was beside himself with joy and excitement. He would rush at the dead animal, and bite her, and bark at the same time, and then come running to me, wagging his tail and looking up into my eyes, as if to say, " Did you see me bite her? I was a little afraid at first, she was so big and ugly, but when I saw her turn towards you I 
forgot all about being afraid." And then, with a joyful bark, he would rush off to repeat the performance.

In a few minutes the men joined me, having heard the shots, and Gale and Davis carried the panther out in the open ground at the edge of the cypress swamp. Here we photographed her, after which Davis and I rode out to camp some twenty miles away, taking the panther with us and leaving Gale to spend the night with

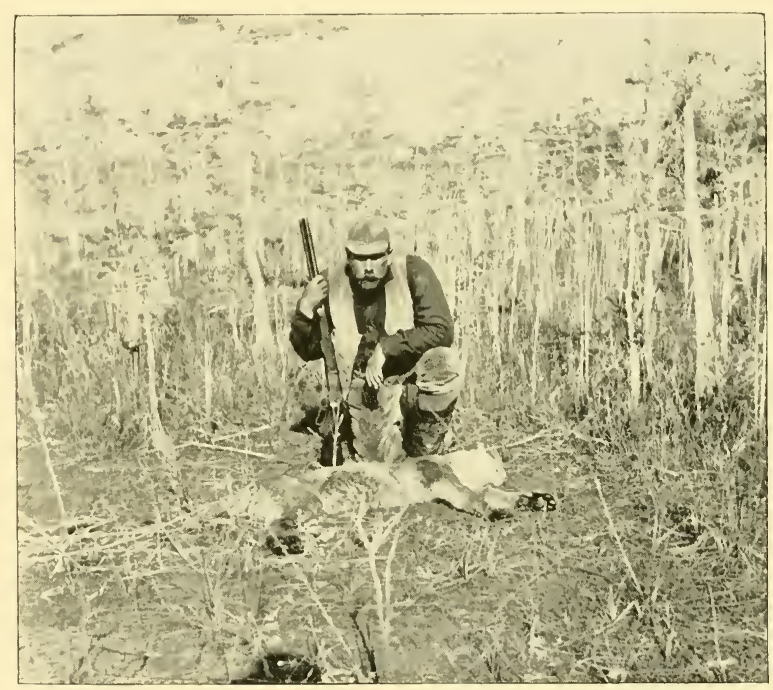

two old hunters, Smith and Wooten, who were in camp some three miles away. This panther was a female and measured about seven feet in length from nose to tip of tail. The next day Gale had a very peculiar experience with a panther, which is worthy of relating. As Gale tells the story, after I had left him he walked to Smith's camp as I had directed, taking the dogs with him. The next morning he started bright and early with the two 
hunters to come out to Little Fish Crossing, and they had not gone more than a quarter of a mile from camp before the dogs found a perfectly fresh track of a good-sized panther. They held a consultation as to the advisability of sending for me, but, knowing that I had probably started for Lake Worth, it was decided to let the dogs run him for awhile.*

The track was on the side of a small cypress swamp, perhaps a few hundred yards in extent, and the dogs ran directly into this and came out the other side, baying loudly. Old man Smith mounted a large fallen tree, and Wooten and Gale walked off to one side, attempting to locate the direction in which the dogs were going. Suddenly they heard the dogs coming directly toward them, and Gale saw the panther bounding along towards Smith, who at that moment also saw him and attempted to take aim. Gale says, at every bound of the panther, Smith, who was on the tree, would raise and lower his gun until the animal was within thirty or forty yards, when he fired both barrels, whereupon the panther made a tremendous spring, landed within a few feet of the tree, and turned a somersault. Gale believed that some of the bones in his shoulder had been broken and that, although he was able to spring forward all right, upon striking the ground with the injured foot it gave way, because after every spring the animal turned completely over. Wooten came rumning up and attempted to fire, when the panther sprang at him, again turning completely over.

The animal then acted in a most peculiar manner, springing into the air and turning over, as Gale described it, "' like a hen with its head cut off." Seeing he was no longer dangerous, Wooten and Smith ran up and finished him. He measured seven feet one inch in length, and was an old male panther, though not as large as they sometimes grow.

* An account of this was given in the Jacksonville Metropolis of May 11, 1895 . 


\section{THE BLACK BEAR.}

THe Black Bear is still numerous in many parts of Florida, especially near the coast. Contrary to what might be expected, it grows as large, if not larger, in Florida than elsewhere in the United States. I have killed old males which I believe weighed over five hundred pounds, and old hunters have repeatedly told me that they have killed them weighing six hundred pounds. Unfortunately, the above

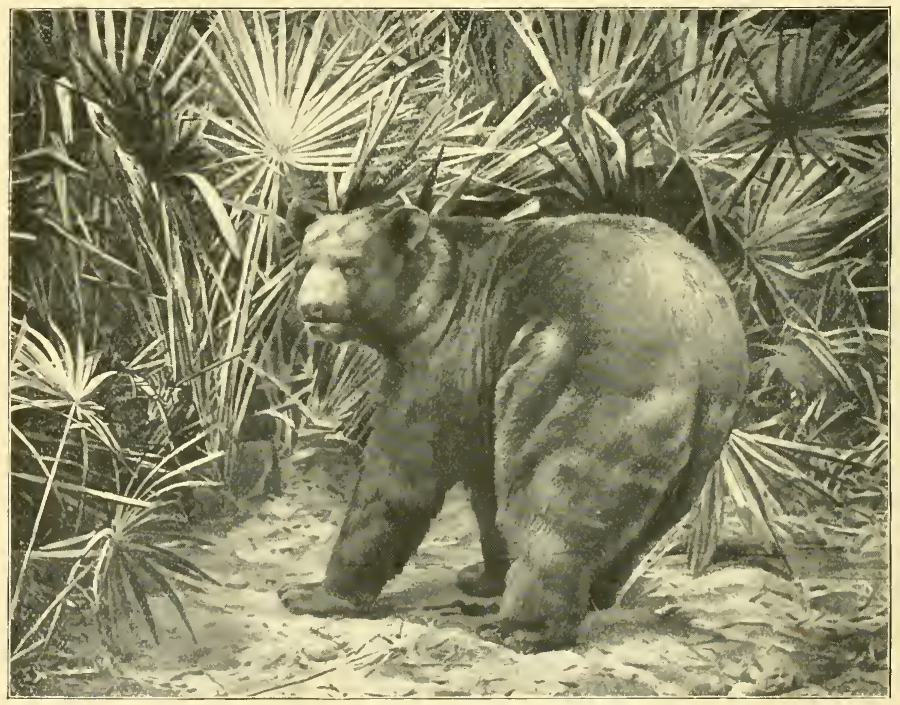

weights were estimated and the animals were not actually placed upon the scales. However, I am satisfied that there is at least one bear in Florida alive to-day (or he was last spring) which will tip 
the scales at over five hundred pounds. Last year I carried scales with me and weighed several bears which I killed, but, unfortunately, none of them were very large. A comparatively small

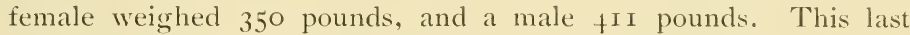
bear was fat, but not as large as some I have killed. The largest bear I ever saw in Florida stood up in the scrub within twenty yards of me, and I had a fair shot at him, but for the first and only time in my life a Winchester rifle cartridge failed to explode. Before I had time to push the lever and throw in another cartridge he dropped out of sight in the high palmetto, and, although the dogs chased him for several miles, he swam the river and I never saw him again.

A Black Bear will not attack a man unless badly wounded or with cubs, although, as the exception proves the rule, one large fellow charged one of my men, who rode ahead of him in open ground and tried to turn him by tickling him with small shot.

Bears hibernate in Florida as they do elsewhere in North America, usually remaining hidden from about the last of December until March. In the spring they hunt for crabs along the shore and eat the young "palmetto cabbage" and the seeds of the mangrove, called "mangrove buds." In June they hunt the beaches for turties' eggs, of which they are very fond. In the fall they subsist principally on the palmetto berries, which grow in great abundance in the sandy lands bordering the ocean beach, and if not disturbed they remain in such places until it is time for them to house up for the winter. They then become very fat and are easily brought to bay by the dogs, generally running but a short distance. The flesh of a comparatively young bear is very palatable when properly cooked, and the fat makes a very satisfactory substitute for lard and is much esteemed by the Indians as well as by many of the white settlers.

Good sport may be, had hunting bears in Florida, but to hunt them successfully one must have a really good lot of hounds. One or two at least must be thoroughly trained "bear dogs." Bear dogs are not easy to find; still, one may be had now and then by paring a high price for him. There are plenty of dogs that will "take" 
a bear's trail and follow it for a short distance, but a good bear dog must chase a bear all day and bay him alone, if necessary, for hours until his master arrives upon the scene. Good horses are also an

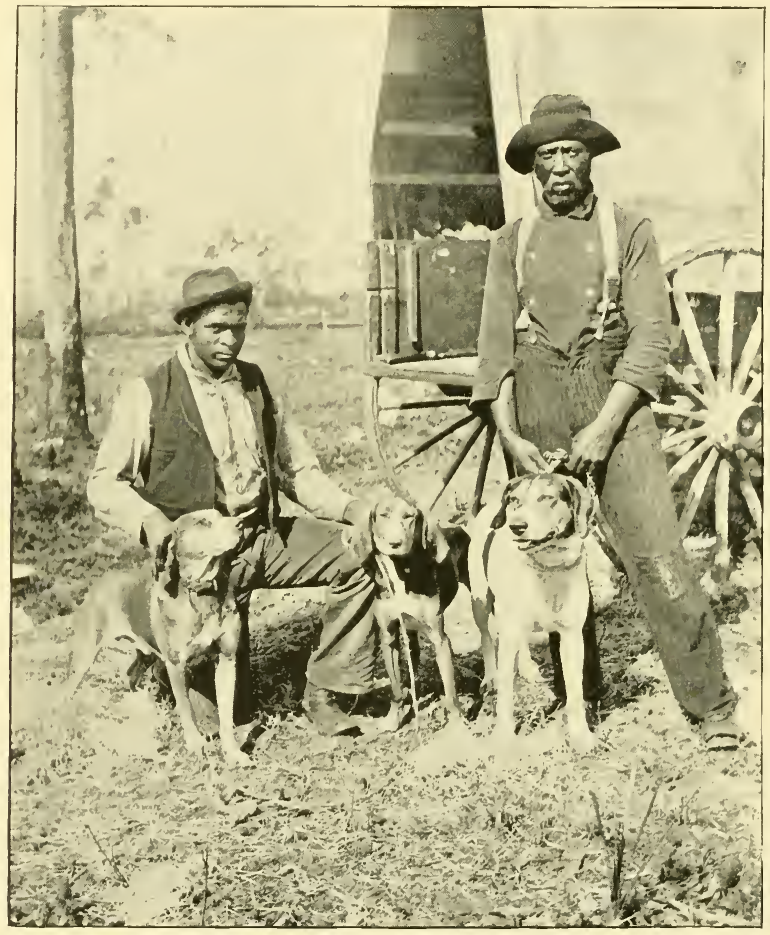

PAT AND GALE, WITH TRIP, DOC, AND TIGER.

important factor. They should be trained to stand where they are left without tying, to be used to rough traveling in rough places, and not at all gun-shy. 
In December, I893, I had particularly good sport in Florida, bagging four bears and chasing several others which I did not bag. Bears were unusually numerous in that locality where I was hunting, owing to the great abundance of palmetto berries and to the presence in the vicinity of two or three good water holes.

The following extracts from my diary will give some idea of bear hunting in Florida under favorable conditions :-

DEc. 8, I893: To-day our shooting party consisted of three guns, - Count A., Mr. C., and myself, - having with us the usual outfit of men, horses, and hounds. To hunt bears luxuriously in Florida the outfit should consist of good saddle horses (used to the woods and not gun-shy), good dogs, and two men, one to follow the hounds and the other to act as general utility man, take messages, and carry the lunch, water, etc., while the "guns" of the party devote their entire attention and energies to heading off the bear or getting to the place where the dogs are baying him, the latter probably in some thick scrub where it is impossible to ride and where the hunter must dismount and push his way in on foot.

Shortly after turning the hounds loose a chorus of exultant yells told us that they had found a fresh trail and were off. The wild shouts of Gale cheering on the $\operatorname{dog} s$ assured us that the bear had been started or " jumped." He ran for about a mile and then bayed in a very thick live-oak hummock. But before any one could get to him he was off again and did not stop until he had run at least two miles or more, when he again stopped in a thick, high scrub, and evidently made up his mind that he had run far enough.

The bear was in a very thick place where the palmetto and small oak trees were higher than my head in places. I pushed my way up to where the dogs were holding their concert : a short recitative by the leading hound being invariably followed by a full chorus, a dog called Blue carrying the high tenor part in fine style. Whenever there was a lull in the performance I could hear the bear panting heavily not more than fifteen or twenty feet from me, but perfectly concealed by the thick scrub. Occasionally his bearship 
made a short rush at the nearest dog, uttering a peculiar sort of rumbling growl or grunt as he did so. During one of these charges I saw him for an instant not more than twenty feet from me, and shot him through the lungs with a bullet from $m y+5-70$ Winchester. He immediately rose on his hind feet and turned towards me, receiring another ball in the chest as he did so. Over he went, with the whole lot of dogs on him as he fell. I shot him once again, fearing that he might still be able to injure the dogs, but it was not needed.

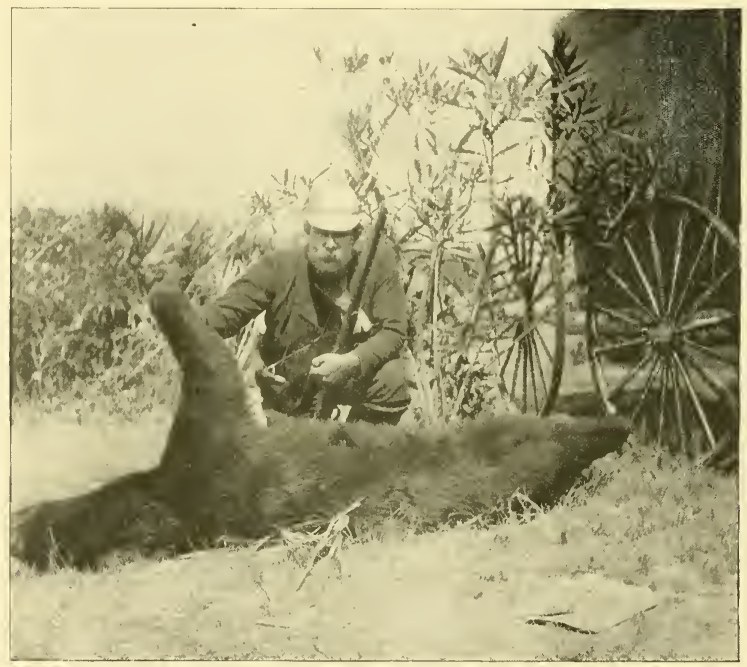

This bear was an old male and very fat. He weighed about five hundred pounds (estimated) and measured six feet two inches from nose to tail (straight line), and eight feet six inches from hind claw to nose : around the chest he measured a trifle over fifty-four inches ; one of his front claws was three and a quarter inches long (measured on the curve): altogether, he was a pretty fair Florida bear. 
SAturday, Dec. I6, I 893 : I hunted the large " hammock" where we lost the big bear yesterday. Tom Nurray went with me. and Pat and Gale looked after the horses and dogs. Trip found a fresh trail of an old she bear and ran south with the other dogs for several miles before they finally "bayed" her in a thick, high scrub. I could hear her growling and snapping at the dogs: but could not see her, and the next moment she was off again with the dogs at her

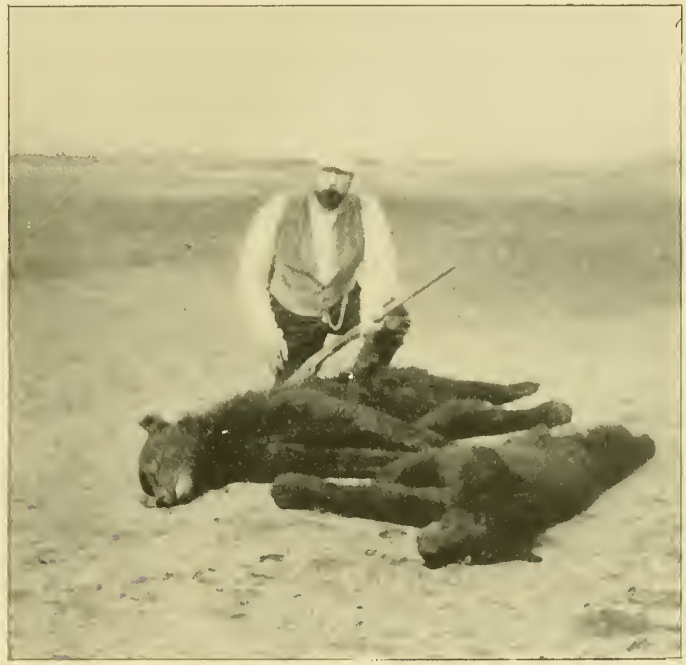

heels. She ran south a mile or more: but "we took the open beach, and, riding fast, headed her in a rather open bit of country with low palmetto scrub not far north of Cape Canaveral. Tom Murray rode in ahead of her, and she turned and passed within twenty feet of me, and I dropped her stone dead with a quartering shoulder shot. She was the first and only bear that I have ever killed with a single bullet so dead as to not even kick after being hit. She was a very old female, although rather small, probably weighing less than three 
hundred pounds. We extemporized a harness with a rope and some straps and Bob succeeded in dragging her out to the beach. The skull of this bear is now in the National Museum.

Tuesdir, JAx. 2, I89t : Trip and one of the other dogs jumped a bear in a hummock, and I had a snap shot at him as he crossed a narrow strip of open ground, and think I wounded him slightly. He ran for a mile or more and then stopped in a thick bit of high palmetto. The day was hot and it was hard work following on foot through the thick scrub, and when I reached the place where the bear was fighting the dogs I was completely exhausted, and instead of going in at once I waited a moment or two to recover my breath. As I stood, gasping and dizzy, the bear started off again, and I had a good view of him as he jumped a fallen tree, and should have hit him, but my hand was too unsteady, and I believe I made a clean miss. In getting over the tree he rested his fore feet and then his hind feet on it, as a dog does going over a wall. After a few moments' rest I pushed my way through the scrub to the beach, where I found Pat leading Bob. Hastily mounting, I galloped south for a couple of miles and heard the dogs "baying " in a thick piece of very high palmetto scrub, filled with small, dead oak trees which had evidently been killed by fire. The bushes were so high and thick I could not see the bear, but the dogs were close to me, and I knew they were close to the bear. I cheered on the dogs, hoping the bear would show himself, and he did. There was a rush and out came Trip and Brown, and the next instant I caught a glimpse of a black object directly under my horse's nose. I tried to shoot, but a branch caught my arm, and Bob's sudden start disconcerted me, and the next instant the bear had disappeared. I followed as long as I could hear the dogs ; but I soon lost them, and after riding about for an hour or more I gave it up and rode back to camp, where I found two of the dogs. Trip and Brown did not get back until late in the evening.

Tuesdar, April 3, I894: The dogs found the fresh trail of a small bear and " jumped" him near a small creek. He ran directly south and I never saw or heard the dogs after the first fifteen minutes. Several hours later they all came back except Tige and 
Brown: they did not return until night. During the ride I startled a Barn owl (Strix fratincolu) out of a small tree, and saw an unusual number of Quail ( C. airginianus), nearly all of which were in pairs.

WEDNEsDAY, ApRIL 4, IS9t: Started rery early and hunted faithfully for some hours, but the dogs failed to find a fresh trail. Bears are wandering about at this season of the year and do not stay long in one place. Saw several fresh deer tracks and dug out the old water holes where the bears go to drink. Two of them were nearly dry.

Thursis, April, 5, isgt: As we drove down the beach this morning the sun was just rising above the horizon. The air was cool and damp. A few willets and turnstones were feeding along the beach, and flocks of Brown Pelicans ( $P$. fuscus) passed us, flying parallel to the shore, about two hundred yards from the beach. They flew in line, one behind the other, and they would all flap their wings or sail motionless, following the example of their leader. I intended to hunt some miles further south, but as we had made rather a late start I determined to look at some old water holes near by, hoping to find signs of bear in the vicinity. Leaving the wagon on the beach, I mounted old Bob, Quarter-

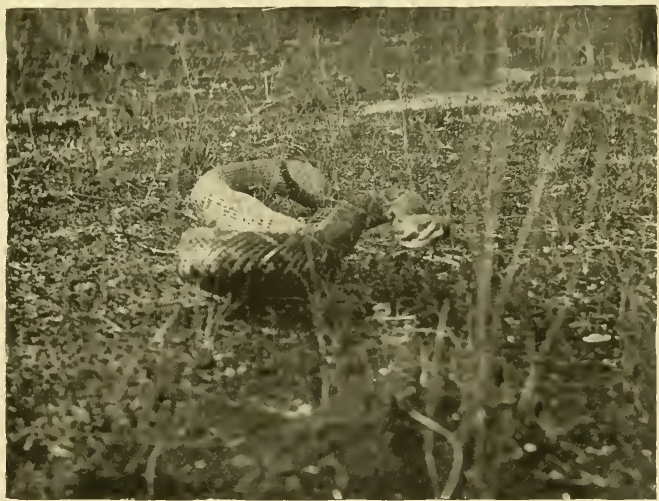

RATTLFSNAKE.

man riding Doctor, while Gale and Pat followed on foot, leading the hounds. Shortly after reaching the edge of a wide marsh we 
rode directly over a large rattlesnake which coiled and rattled, but did not offer to strike the horse as he stepped over it. I dismounted and shot its head to pieces with a rifle bullet; first taking several snap photographs of it, holding the kodak as close to its ugly head as I dared as it lay there rattling and ready to strike. It was a thick, heary snake, although not a very long one, measuring five feet, nine inches. It had nine rattles and a button.*

Upon reaching the water holes I found one of them dry, but there was water in the other and a large bear had visited it within a few hours. His tracks were very plain and fresh in the soft mud and sand about the hole.

The dogs got away well together, Trip and Tige leading, followed by Brown and the others. Several of my dogs will run a bear well for a short distance, but will not fight or bring him "to bay" by biting and snapping at his legs. Trip will follow a bear all day and bay him alone at times, and this was the case to-day. The dogs jumped the bear within ten minutes after being started, and he ran for about two miles to the north. Quarterman and I following along the marsh and keeping within hearing of the dogs and Gale. Gale's yells to encourage the dogs could be heard when we could not hear the hounds. Soon after the bear turned to the southeast and we could hear nothing of the dogs or Gale.

Quarterman rode further north, while I galloped south to an old trail through the serub, on the chance that the bear might have gone that way. As I reached the trail I heard Trip, and a few minutes after saw the bear crossing a ridge about a hundred yards off, where the scrub was low and thin. I had a fair chance at him, but just as I fired my horse swerved just enough to spoil the shot. and the next minute he was off and away in a thicket where no horse could follow. Pat came up with Tige and Brown, and I put them on the fresh trail, which they eagerly took and went off giving tongue finely. Shortly after two, or perhaps three, of the dogs "bayed" the bear in a small live-oak hummock, but he was off again before I could come up with them. It was now getting hot and three hounds came 
back to us very much in need of water and overcome with the heat. On the marsh I met Quarterman and we went north again to a thick, high scrub where we hoped we might find the bear bayed. All the hounds had come back to us except Trip and Brown, and we did not know where they were or what direction they had taken. When Trip becomes tired he makes little noise.

Just as we had about made up our minds that we had lost the bear I heard Trip bark not two hundred yards from us, in some thick, high scrub. We went in on foot, leaving the horses on the edge of the marsh. We separated, keeping about fifty yards apart, although we, of course, could not see one another. Trip was obstinately silent and we could not locate the exact place where he was, but we were sure the bear was there somewhere, for if he had started off Trip would have made noise enough. After going a short distance through a most discouraging tangle of roots and bushes I heard Quarterman shout and then a series of howls from Trip, that seemed to move rapidly south, and it did not need Quarterman's yell of "He's off to the south" to make me hurry back through the scrub to where I had left my horse, mount him, and gallop as hard as I could to the old trail. There I found Gale and Pat and several of the dogs. Gale, who was riding Quarterman's horse, shouted to me that the bear had just crossed the trail going south, followed by Trip all alone. There was just a chance that I might head him off on a trail leading to the beach, about half a mile further south, so away I rode as fast as I could make "Old Bob" go over the rough trail. I feared I would be too late, but I made it just in time, for, as I turned into the cleared path at a gallop, I heard Trip's voice close to me, and out of the scrub came the bear not thirty yards distant, but behind me, so that I had to turn half around in the saddle to fire. It was a snap shot, but I dropped him in his tracks with a bullet through the shoulder. He was up again, however, in an instant, Trip hanging to him bravely. To dismount and fire two more shots from the Winchester 45 - did not take long, and the bear lay dead, with Trip biting and tugging at his flanks. This bear was an old male; I weighed him carefully, and he tipped 
the scales at exactly $35^{\mathrm{I}}$ pounds. This was not at all heavy for the size of the bear. He was rather thin and in good running condition, which accounted for the long chase he had given us. He measured eight feet and four inches from hind claw to end of nose, six feet and two inches from nose to tail, forearm seventeen inches, and chest forty-seven inches. When fat he would probably have weighed nearly five hundred pounds. The width of his forefoot was six and a quarter inches.

Monday, April 9, IS94: To-day I found a fresh trail of a medium-sized bear about five miles to the south. It was early, the ground was still damp, and the dogs were fresh and eager. Away they went in a bunch in full cry, Trip and Tige in the lead. Brown and Dan are down with the ". staggers," and I miss Brown's voice. I followed them the best I could, which was not very fast, as the scrub was thick. They " jumped" the bear within five minutes of starting, and he ran due south, so I turned and rode for the open beach. Once out of the thick scrub, I galloped south for several miles before again taking the scrub, hoping to head the bear. After waiting for ten or fifteen minutes and hearing nothing of the dogs, I saw a man in the distance waving his hat. It was Gale, with the cheerful information that the bear had turned and gone north. Away I went up the beach to a trail some miles north of me, and as I neared it I heard Trip baying something, apparently all alone in a small hummock about half a mile away. The scrub was very thick and high, but, pushing my way through it I arrived within about two hundred yards of the spot, when, crash, away went the bear, showing himself for an instant as he dashed into a lot of high bushes, and I never saw him again. Ride where I would, I could not hear the dogs anywhere, or, rather, the dog, for Trip was the only one following him. The others had given it up and joined us, one after the other, as we rode back to the wagon. Just as I was starting home Trip came back to me, looking very tired and hot, and, I have no doubt, thoroughly disgusted. Three of the hounds have the "staggers," which often proves fatal in this climate. Their hind legs seem to be paralyzed, but they apparently suffer no pain. 


\section{.}




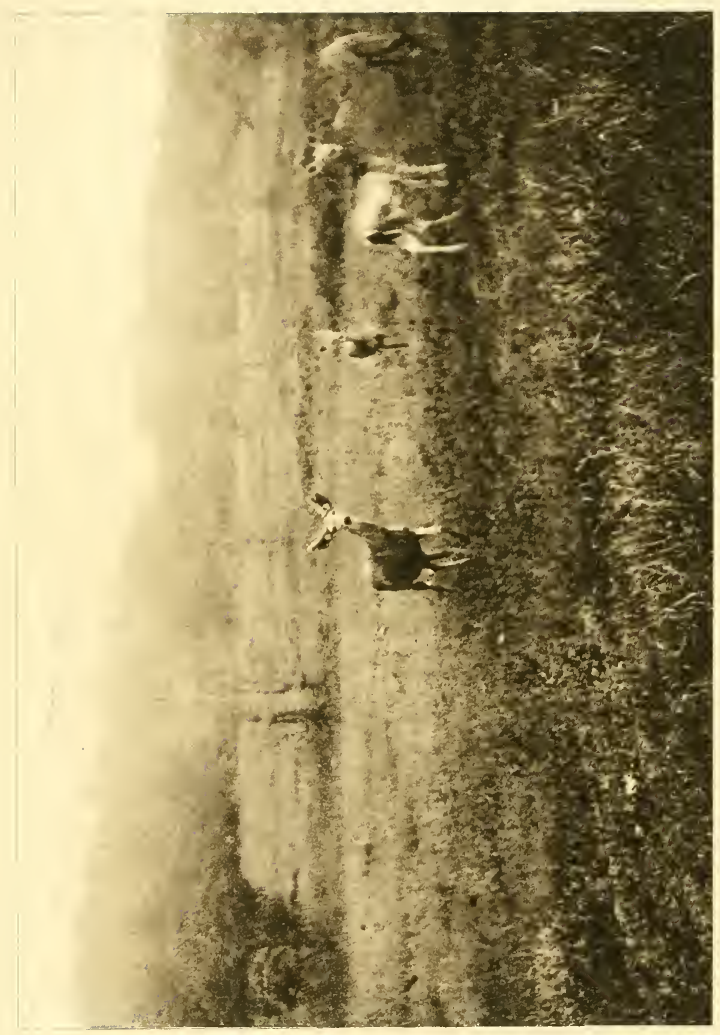




\section{DEER.}

DEer hunting is by no means such easy work as one who has not tried it might imagine. Of course, deer are so numerous in some localities that any one who can shoot straight can hardly fail to kill one in a day's hunt; but such places are becoming more rare year by year. Not so very long ago it was no uncommon sight to see

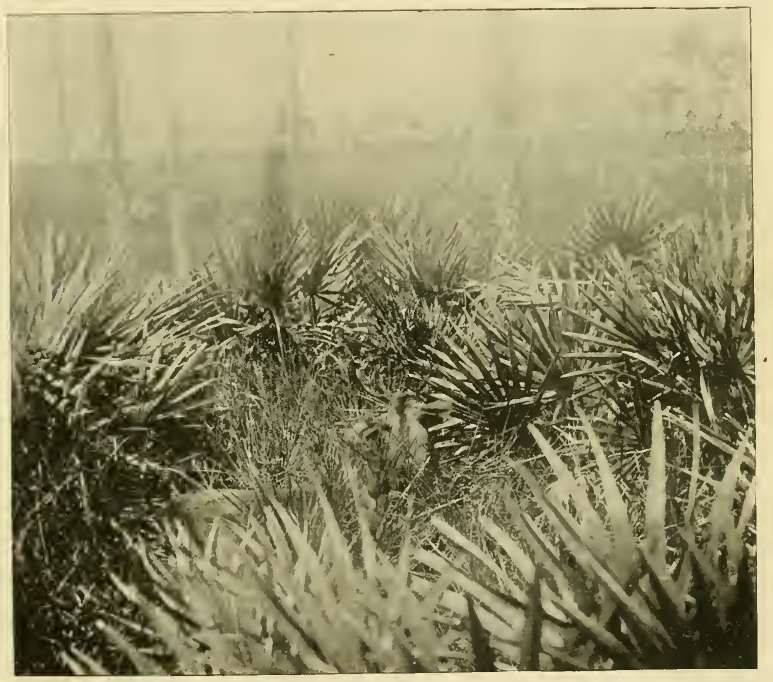

eight or ten deer feeding on a prairie at one time, but such sights are rare nowadays.

Deer are usually hunted in one of three ways (fire hunting not included, the latter being rarely indulged in by a true sportsman), 
viz.: (I) Hunting on horseback and running the deer with hounds; this method to be successful requires a party of hunters and some one to direct operations who is thoroughly acquainted with the country. (2) To "slow trail" them, which is usually the most satisfactory way to hunt them. A hound trained to follow a trail slowly and without barking is used, and must go slow enough to enable the hunter to keep within a few yards of him all the time ; sooner or later the deer is " jumped," usually within easy shooting distance. The third method is known as still hunting. To be a successful " still hunter" requires keen eyesight combined with a knowledge of woodcraft and the habits and ways of deer which comparatively few white men possess. Indians always hunt deer in this manner, but they have been

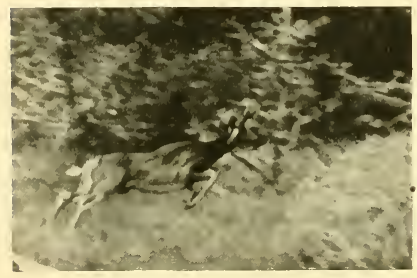
trained to it all their lives, and always hunt where they know there is plenty of game. A single deer may often be stalked and shot almost in open ground where there is only an occasional bush or clump of grass for cover.

By keeping to leeward of the animal, and creeping forward while it has its head down feeding, and remaining perfectly motionless when it lifts its head, one may often approach within easy shooting distance. A deer, as a rule, shakes his tail before lifting his head. On one occasion I had approached within perhaps 125 yards of a buck in an open prairie when the grass was not over twelve or fifteen inches high. I was creeping along on my hands and knees, when he suddenly raised his head and looked directly at me before I had time to lay down in the grass. I remained perfectly still, and after gazing steadily at me for a moment he stamped once or twce, advanced a few steps and stamped again. but after examining me for some time he apparently came to the conclusion that I was part of the scenery and not dangerous : whereupon he commenced to feed again. 
When a deer is stalked and sees something of which he is afraid he generally utters a snort of alarm, and then away he goes, his white tail held straight up in the air, showing clearly as he bounds high over the

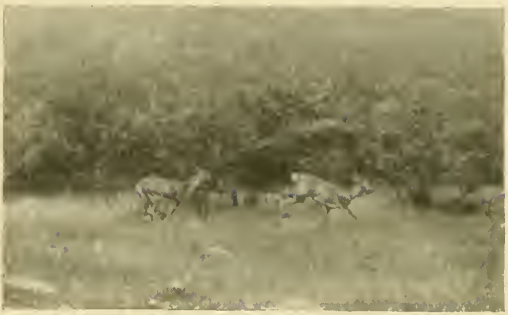
bushes. If you have fired at him and he goes off with his tail down you may be sure he is badly wounded. I have shot at deer at long range and seen them go away without raising their tails, but could find no signs of blood along the trail; yet upon following it for a short distance the deer would be found quite dead. Oftentimes a deer will bleed badly from a comparatively slight wound, and again be seriously wounded and bleed externally but little.

The Florida Deer is smaller and varies slightly in color from the true $C$. zirginianns. A fullgrown buck will often not weigh over I IO pounds, although I have killed them considerably larger, and probably they occasionally (though rarely) approach in size their Northern relation. In Florida as elsewhere the bucks drop their antlers every year, usually about February. The rutting season occurs in septem- 
ber and early. October, and the young are born in April and early Maly.

The Indians burn the prairies early in the year, and deer are attracted to the "burns" by the young and tender new grass. It is by using such methods and being expert hunters that they kill wreat numbers of these animals; but I am wald to say but very little of the meat is wasted: what they do not sell, they smoke and keep for their own use.

NuTE.-Two of the photograph of deer were mot taken in Florida. The full-page photogravure represents a Alut of wild deer on the author's preserven in Mastachusetts. 


\title{
ALLIGATORS AND CROCODILES.
}

\author{
ALLIGATORS.
}

THE largest alligator I have ever seen in Florida was killed near Enterprise, on the St. John River, and measured fourteen feet within a fraction of an inch. I have killed several alligators over twelve feet in length, and one which measured thirteen feet two inches,

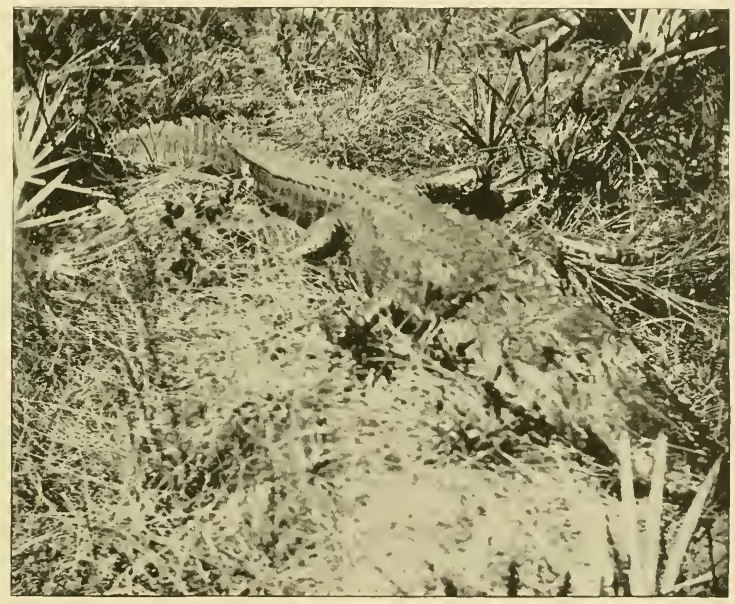

ALLIGATOR.

which I shot on the St. John River near the mouth of the Wikiva Creek. Large alligators have of late years become rather scarce, although nearly every year I kill one or more which will exceed eleven feet. 
One often hears marvelous stories regarding the size of alligators killed by this or that hunter : but I do not believe that there exists to-day in Florida an alligator which will actually measure seventeen feet in length. The head of an alligator killed on the St. Sebastian River in I893, purchased by Mr. W. V. Rhoads, of Rockledge, Florida, is so much larger than any specimens I have ever seen that I did not for a moment discredit his statement that the animal measured when killed a trifle over sixteen feet in length.

The alligator lays its eggs in the sand, where they are hatched by the heat of the sun, and the young alligators then collect in some small hole where the mother keeps watch over them. The piping, or grunting, as it is called, of the young alligator somewhat resembles the piping call of a hen turkey. It is imitated by the " skin hunter," who is usually able to call to the surface almost any old alligator which may be lying within hearing distance. I have

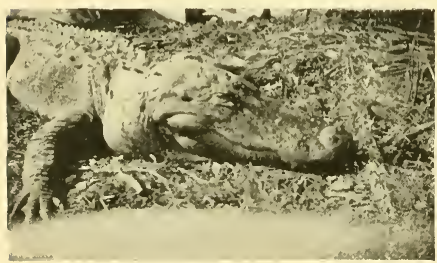

seen John Davis repeatedly call alligators to the surface of small ponds where there was no sign of one when we arrived. After two or three grunts, as it is termed (although the call does not resemble a grunt at all), one or more alligators would rise to the surface and lay looking at us for a moment. The hunter has to shoot quickly under these circumstances, as the alligator soon discovers the deception and will not come up a second time for any amount of grunting. The little alligators may be called to the surface in a similar manner and caught by hand or a small dip net. I have many times caught dozens of them in this manner by simply leaning over the edge of a bank under which were a large number of young alligators and " grunting "them to the surface, where they were seized and placed in a box, until nearly all of them had been captured. An alligator under fifteen inches is comparatively safe to handle, as their teeth 
are extremely small. Larger than that, they are sometimes inclined to be ugly and their small teeth cut sharply.

Years ago the alligator was very destructive to dogs. Young dogs which went down to the rivers to drink often did not return, and the howling of a dog would instantly bring to the surface any alligator which might be within hearing distance. Hunting dogs while swimming streams and ponds were often killed or badly bitten by these animals : but at present so few of the large ones are left, and they have become so shy, that it is a rare thing to hear of dogs being injured by them.

The alligator is often found on land some distance from water; in such cases it is well to keep away from its

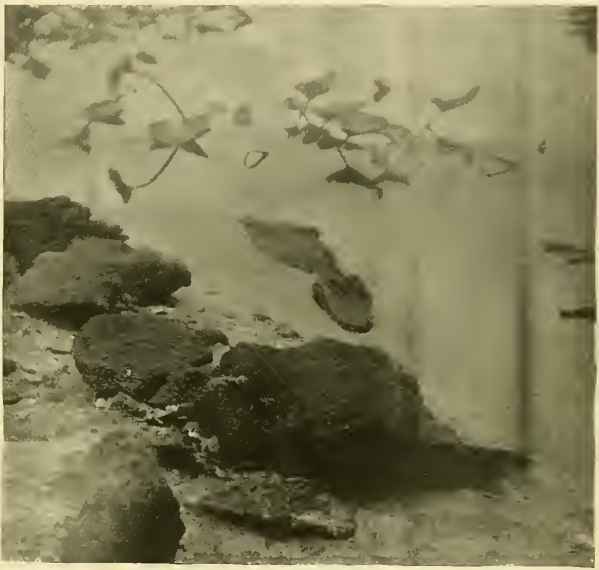

ALLIGATOR.

tail, as it strikes with great power and is capable of doing considerable injury. The danger from this is probably exaggerated.

One method of hunting alligators which is quite commonly practised is to pull them out of their holes under the banks of the rivers and on the borders of the ponds. When the water gets low enough at certain seasons of the year these holes may be found, and br investigating them with the aid of a long pole, if the alligator is at home he will soon give signs of life, usually grunting and moving about. Oftentimes he will savagely bite the end of the pole when it touches him. A large hook, resembling a shark hook, is attached 
to the end of the pole, and a rope fastened to the hook in case the pole should break. The alligator may then be hooked, pulled out of the hole, and shot; but it frequently requires two or three men to accomplish this if it be a large one. While being drawn to the entrance of the hole he roars and bellows in a lively manner. I have taken several alligators in this manner which measured over eleven feet in length.

When alligators fight with each other they attempt to seize the upper jaw. I once saw two large alligators fighting in a very shal-

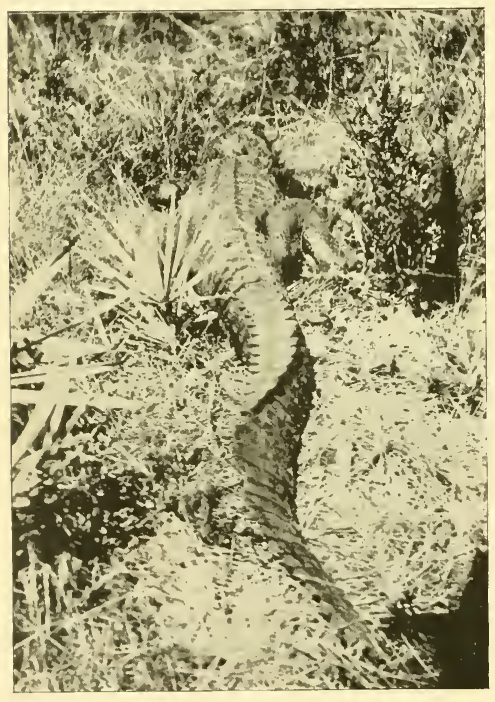

ALLIGATOR. low pond; each made several ineffectual attempts to obtain the jaw hold without success. At last the larger one succeeded in seizing his opponent by the upper jaw and immediately rolled over and over, breaking his opponent's jaw close to the head, killing him instantly. This is, I am told, the usual method employed by alligators when fighting with one another.

In localities where alligators are much hunted they become very wary and shy, and lay with their heads toward the water, sleeping with " one eye open," and at the slightest sound they do the " vanishing lady" to perfection. A hunter paddles cautiously up some creek where he knows a large alligator sometimes repairs for an afternoon siesta - one careless motion so that the paddle just touches the side of the boat and a loud splash in the distance tells him his chance to kill that alligator has gone for that day. 
The skin hunters kill alligators at night, using a light with which they are able to " shine" their eyes. The alligator does not fear a light, and as the boat approaches within a few feet of the animal it is shot without difficulty. Thousands are killed annually in this manner, and their skins are shipped North or sold to intermediate dealers in Jacksonville and ricinity at the rate of ten cents per running foot. The much more sportsman-like way of hunting the alligator is by ". still-hunting " them in the daytime, paddling silently up the creeks and rivers, where at times they may be found asleep or sunning themselves on the banks. In places where they have been much hunted this is by no means easy to do. Where the alligators have not been disturbed they are tame and lazy, and I have passed within a few feet of several that gazed stupidly at me without attempting to leave the bank. A good rifle is the proper weapon with which to hunt alligators. I prefer a $45 \mathrm{Winchester,} \mathrm{either}$ $+5-70$ or $45-90$, which has power enough to kill the animal and not merely wound it and allow it to escape and die. A shot striking the eye or any portion of the head so as to penetrate the brain is almost instantly fatal. It is rare that a shot in the body will stop an alligrator where he lies, and it is not advisable to shoot at the body if the head is exposed. The old idea that a rifle-ball would glance from the skin of an alligator does not apply to modern weapons. If a rifle-ball strikes fairly it will penetrate the skin without difficulty and will sometimes pass completely through the body.

Before closing my remarks on large alligators I will refer to an entry which I once saw in the register of the Brock House.

In the old days, when transportation was more difficult than it is at present, the Brock House was about the end of civilization and was a twenty-four hours' trip by boat from Jacksonville. It was at that time a great resort for sportsmen, who were attracted there by the fishing and shooting to be had in the vicinity. The old register, which extended back a great many years, contained some queer records, some of them of doubtful veracity. Among others, some one has written: "March I9, IS72, killed a large alligator, the largest seen here this year : the stomach contained a boot, a piece 
of pine wood, a fisherman's float, and some small fish." Immediately beneath this record was another which evidently some wag had added: "March 2.t, killed a much bigger alligator than the one mentioned above. The stomach contained a gold watch, $\$$ ro,ooo in government bonds, and a cord of wood." On the next page, written in a neat, unobtrusive style, was inscribed the following : " Shot the biggest alligator ever known in Florida; the stomach contained the remains of a steam launch, a lot of old railway iron, and a quantity of melted ice, proving that it existed during the glacial epoch."

\section{CROCODILES.}

Tine crocodile occurs in the rivers and bays of extreme South Florida, but is seldom found far from salt water, rarely being found

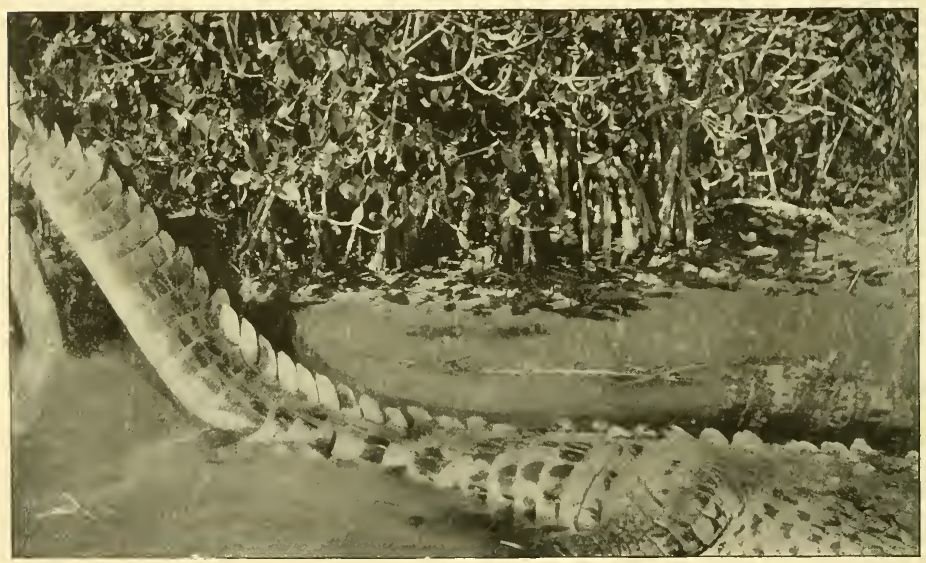

CROCODILE.

in any of the fresh water streams. It may easily be distinguished from the alligator by its narrow snout and the holes in the end of the 
upper jaw into which the two front teeth of the lower jaw enter. Is a rule, it lives in the bays and inland creeks which abound in the southern portion of the State. Passing through some of these creeks, where the banks are one or two feet above high water mark, numbers of their well-worn slides may be seen, where they climb out on the bank to sleep and sun theniselves. It is claimed that the crocodile cannot be hunted at night, but as I do not hunt in that manner I have no personal knowledge of the subject. The hunters claim that the crocodiles will not look at a light and that they cannot "shine their eyes," as they can those of an alligator, which is lucky for the crocodiles, as they are not very numerous even now.

Crocodiles grow to a larger size than the alligator. At one time

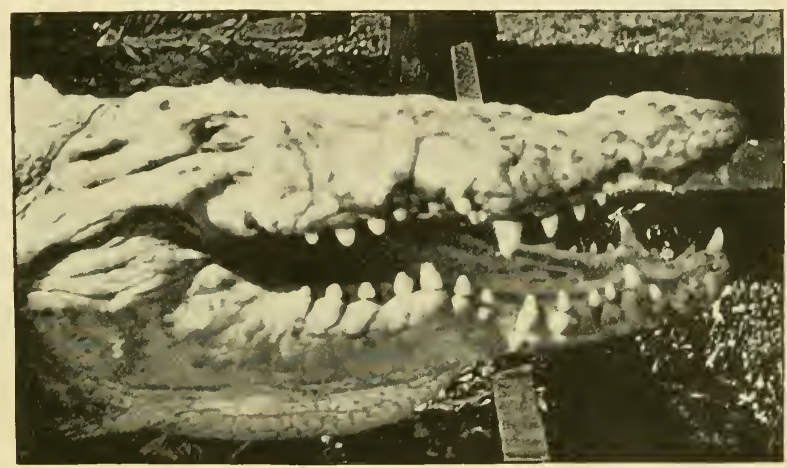

HEAD OF CROCODILE.

they were numerous in Indian Creek, Biscayne Bay, and also in Arch Creek in the same locality, but they are not as plenty now as formerly. Further south, through Card Sound and below, is the present home of the crocodile in any numbers, and the intricate network of islands and lagoons makes it very difficult for any one except a professional hunter to find them. The largest crocodile I have ever killed measured thirteen feet eight inches in length. I 
shot him in a small creek near Card Sound, in the spring of 1895 , and saw another at that time which I feel certain was at least two feet longer than his companion.

An old hunter by the name of William Freeman told me he saw a crocodile in a shallow creek near Card Sound, and, as he could see the animal perfectly, tried to form an approximate idea of its length

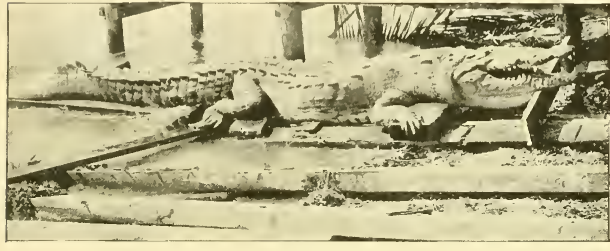

CROCOIILE.

by pacing the bank of the creek parallel with the crocodile. He stated that he believed this crocodile would measure at least nineteen feet. Such estimates are of comparatively little value except to show that there are larger crocodiles in South Florida than have as yet been killed: and it is fair to assume that there are crocodiles in Florida to-day which will measure seventeen feet or more in length. The skin is not as dark as that of an alligator, being slightly variegated, lighter and darker in places, and the animal when asleep on the bank appears to be clay colored, rather than black, as in the case of the alligator. The large one which I killed looked ashy gray as he lay on the bank about fifty yards from me. 


\section{TURKEYS.}

WHERE turkeys are numerous a great many are trapped every year by the native hunters by methods which do not redound to the intelligence of the turkeys. A place is found where they are in the habit of "using," as it is called. Corn is scattered about, and, if that is eaten, more corn is placed there the next day. They are fed in this manner for a week or more, until the turkeys become accustomed to going there for food. Then small logs are laid, forming a square box about six or eight inches in height; possibly two logs on each side, one above the other. In this is placed the corn, and the turkeys enter it readily, as the obstruction is not sufficient to make them fear any harm. The next night another log is added on the four sides, raising the box gradually, perhaps a foot or so each night, until the small logs form a cone-shaped box, narrowing at the top, leaving an opening of perhaps a foot or eighteen inches by which they can enter at the top. Corn is placed in the box and a few kernels leading to it, as usual, and the turkeys, mounting the last $\log$, enter it and eat up the corn. The opening has now become so narrow that, although a turkey can easily jump down through it with closed wings, it is impossible to jump out of it with wings spread. I have tried this method on one or two occasions, but without success, although I have no doubt as to the truth of the statement, which is vouched for by a number of old residents and hunters.

Another style of trap is a $\log$ pen with a large tunnel under one side. The turkeys follow the corn through the tunnel and do not attempt to go back the same way, but run about the sides of the pen, poking their heads through the openings between the logs.

Turkeys are still numerous in some parts of Florida, although they have been practically exterminated in many localities where they were once common. They are gregarious and usually prefer 
a well-watered country, roosting in a swamp or on the borders of some stream or pond. When a native hunter discovers a roost he conceals himself near it at night and often kills nearly the entire flock, shooting the under ones first, so that the dead bird in falling will not alarm the others.

In the springtime the gobblers may be "called" by imitating the plaintive piping of the hen, and this is a common method of shooting them. Usually a quill is used to imitate the call, but some hunters can produce it with their fingers and lips. The hunter conceals himself and calls softly until the gobbler approaches near enough to be seen and killed. Occasionally a flock of turkeys will be found feeding in the open ground, and they usually fly to some heavy timber and perch themselves high up among the top branches, affording a good chance for rifle practise. In following a turkey's trail the hunter must keep up with the dog and go as fast as the nature of the ground will permit. A turkey will usually run for some distance ahead of a dog before attempting to fly, and if the hunter follows fast enough he will stand a good chance of getting within shooting distance before he " jumps." I have seen many a fine gobbler go soaring away two or three hundred yards ahead of me which I probably could have killed had I kept within easy shooting distance of the hounds.

When the dog shows by his actions that the turkey is only a short distance ahead that is the time that the hunter must use good judgment.

Now the turkey must be "flushed" or made to fly, but not until within shooting distance. If not pushed the turkey will often run a long distance ahead of the $\operatorname{dog}$ and perhaps escape in some impenetrable swamp. When the scent gets very warm let the dog hurry a little, but not go so fast that the hunter cannot keep close to him. The turkey, hearing the dog close behind and finding he cannot escape by running, goes into the air with much heary flapping of wings, and if the hunter is sixty or seventy yards behind his dog he is probably a hundred or more away from the turkey, and his chances of bagging that gobbler are extremely slim. 


\section{TARPON FISHING.}

D.r was just breaking when Will and I pushed our boat from the wharf. It was a typical Florida spring morning, with the usual gorgeous cloud effects so common in these latitudes; the whole eastern sky was banked with crimson clouds shading softly into the pale blue higher up where the cloud banks suddenly ceased. Gradually the changing colors paled and paled, fading into dull gray and white as the sun rose higher and showed his fiery edge over the tops of the low mangroves on the key opposite. The bay was as smooth as a pond; the water being scarcely rippled by the light breeze which bore to us the faint chattering and whistling of a flock of blackbirds on the keys opposite, and we could distinctly hear the voices of two men in a boat far over near the other shore, a mile or more away.

We passed several low oyster bars, which are usually covered at high tide, and just beyond one of these Will stopped rowing and, nodding his head towards the reef, said: "Do you see the deep water just to the south of that bar? That is where I saw several tarpon yesterday - and there goes one noze."

I looked quickly in the direction he was pointing and caught a momentary glimpse of a large fin cutting the mirror-like surface of the water : a dull gleam, and then all was quiet save for the gradually widening ripples which marked the spot where the great fish had risen.

"Quick," cried Will ; " throw well out ahead of that ripple and if he takes it give him plenty of time before you strike."

Swinging the heavy rod backwards, I made a strong cast and the line, weighted with half of a mullet, ran freely from the reel. It was a good throw and the piece of fish struck the water not twenty feet from the spot where the tarpon had risen. Loosening the line and seeing that it ran freely under the leather thumb check, I waited. 
Will cut up small pieces of mullet and threw them over the water in different directions, while I anxiously watched the line. Five minutes passed, ten minutes - suddenly my line began to run from the reel with a strong, steady movement.

"Steady," cried Will; "give him time to get the bait down his throat. Don't strike too quick. Now give it to him. Now! Now!"

Holding the rod firmly with both hands, I checked the reel and struck hard, so hard that the stout rod bent with the strain, and

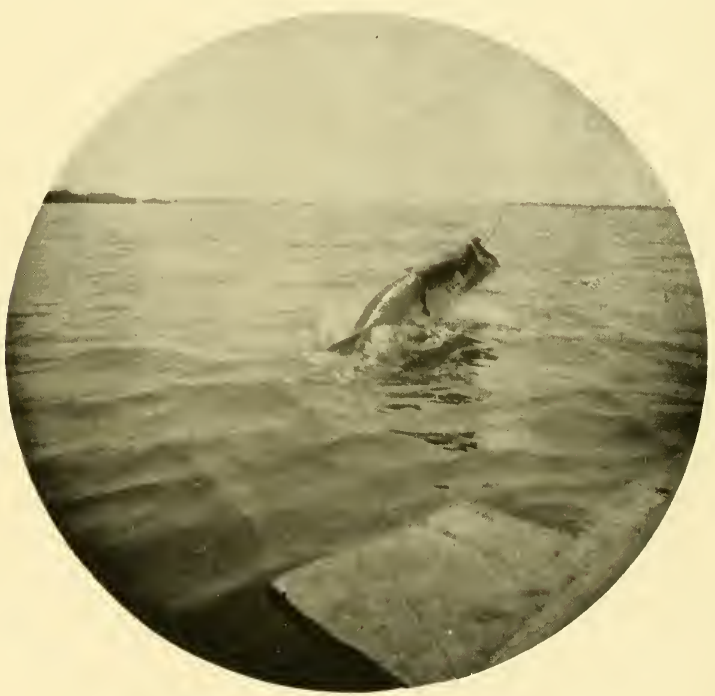

TARPON.

instantly, with a tremendous rush, a huge silver, gleaming monster flung himself completely out of the water, shaking his head savagely. Down he came in a splash of white foam, and it required no warning cry from Will to make me brace myself for the rush 
which we knew would come. The stout rod bent like a reed, and the carefully tested line sung from the reel in spite of the strong friction of the leather check pressed firmly against it; but the strain was too great to last, and the line ran out slower and slower and presently the reel ceased to turn; but with a strong, steady pull the great fish moved steadily on, towing our boat rapidly behind him.

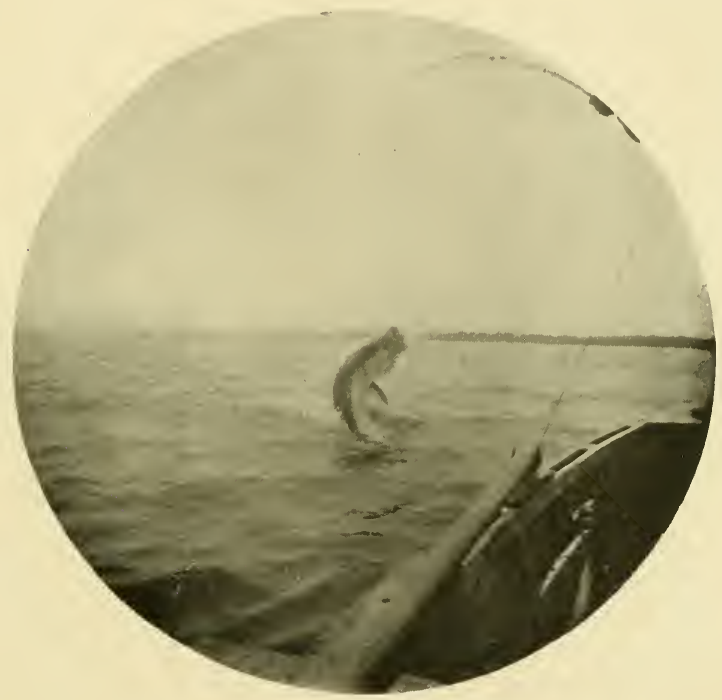

TARPON.

Suddenly the bent rod straightened with a spring. It needed no cry from Will to tell me the fish had doubled and was headed towards us. I heard him grunt as he threw his weight on the oars, and, holding my rod firmly, the butt well braced, I awaited the coming strain. Almost instantly it came. Again that stout old rod bent like a bow and the reel hummed, and again, shaking his head savagely, the tarpon threw himself fully two feet above the water. 
Never shall I forget the scene which followed. Never, if I catch a thousand of his kind, do I expect to see a more magnificent fight for freedom than that grand fish made in his struggles to rid himself of the barb within his jaws. Once, twice, four times he cast his whole length into the air in his mad struggles. The water foamed and boiled as he fell and sank, to almost immediately reappear, hurling himself high into the air, shaking his head as a dog shakes a rat, his blood-red gills showing in striking contrast to his gleaming silver body. As he sank for the fifth time the strain on the line ceased; turning the reel, there was no resistance, and I heard a sigh from Will.

" He's off ; it can't be helped; but wasn't he a dandy?"

I said nothing, for I was sadly disappointed. To have had a fine tarpon hooked for fifteen minutes, and then to lose him was dis-

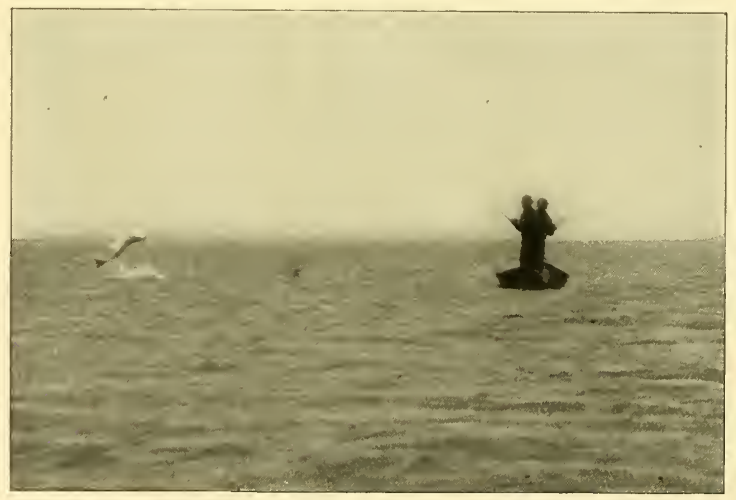

THE LEAP OF THE TARPON.

couraging; but, as Will said, it could not be helped, and the only thing to do was to try for another. So, rowing back to our original position, we baited the hook with a fresh and enticing bait, and settled down quietly to wait. 
Perhaps twenty minutes had passed when again something took the bait and moved slowly away with it. I struck hard, and as I did so a huge tarpon hurled himself twice out of the water not twenty yards from the boat, and immediately started off across the bay. Holding the rod high up, I gave it all the strain I dared; but despite it all, the splendid fish towed us fully half a mile before showing any signs of fatigue. Slowly and gently I "reeled him in," as the strain relaxed, until we could see him not more than ten feet from us. Gradually I drew him nearer and nearer, while Will leaned over the side of the boat, holding in his hand a huge gaff, which, the next moment, was fastened in the side of the tarpon.

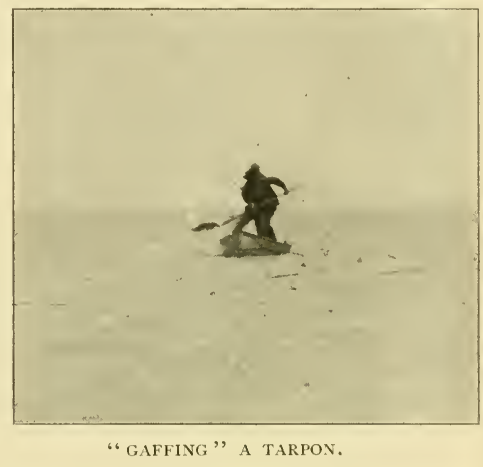

A short struggle and a large specimen of the most magnificent game fish in the world lay on the bottom of the boat, glittering brilliantly in the sunlight, one sparkle of silver, blue, and gold.

As I wished to preserve the skin and the day was warm, Will advised returning home at once; so we turned the boat and rowed back, having had sport enough for one day. Although larger fish are often caught, my first tarpon proved a good one, measuring six feet one inch in length, and weighing $\mathrm{I}_{2} \mathrm{O} / 2$ pounds. 


\section{HUNTING GROUNDS OF FLORIDA.}

To those who do not desire to rough it, but wish to have an occasional outing with the gun and $\operatorname{dog}$, Florida offers the rather unusual combination of very good sport in the immediate vicinity of comfortable hotels.

From Jacksonville it is but a short distance to the mouth of the St. John's River; and in the vicinity of Pilot Town, and Mayport,

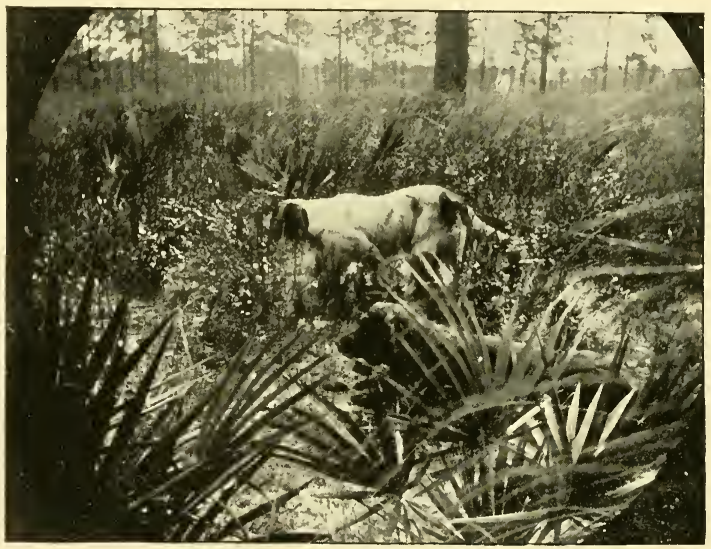

A "POINT" ON QUAIL.

and-about Fort George Islands, fair bird shooting may be had at the right season. Plover and yellow-legs abound during the migrations, and in the old days Talbot Island was an especially good place for curlew. With good dogs and a guide who knows the country, fair bags of quail and snipe may be made within easy driving distance of either Jacksonville or St. Augustine. A few bears and deer still linger in the swamps between Jacksonville and Pilot Town, but for 
this kind of shooting one should go farther South into a more unsettled country.

Quail a re abundant throughout Florida. The best quail shooting which I have ever enjoyed I had at what is known as Dago Prairie, about fifteen miles from Enterprise, on the St. John's River. Enterprise at one time was noted for its

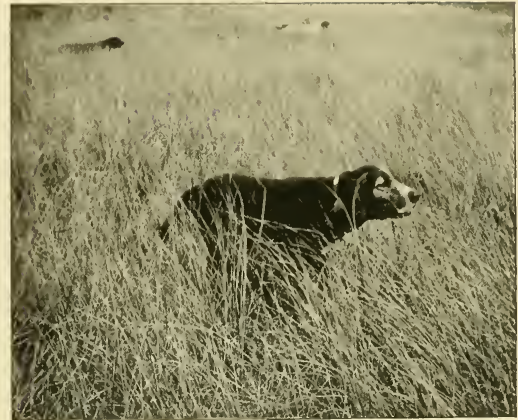

TOMI quail-shooting. On one occasion, using three dogs, I found fourteen coveys, and killed eighty-two birds with a twenty-gauge gun, reaching the hotel before dark. This occurred several years ago, and probably better sport may now be had in the flat woods west of Lake Worth or south of Tampa. I merely mention Lake Worth and Tampa as there are good hotels at both places, but as far as the quail shooting is concerned it may be had almost everywhere in South Florida.

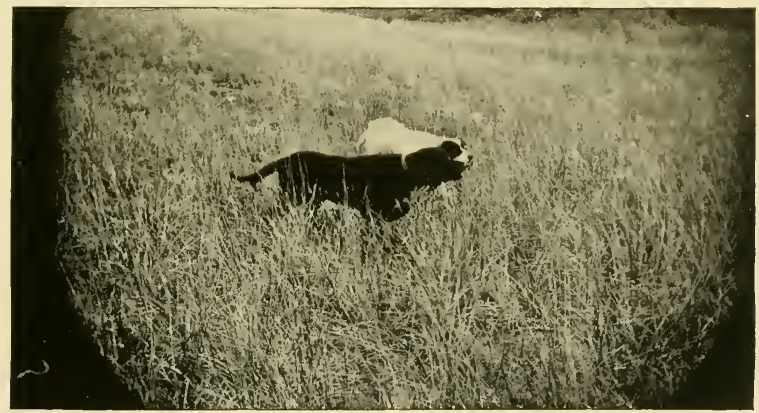

ROBIN AND PRINCE " POINTING" QUAIL. 
Dogs are absolutely essential to successful quail hunting. Of course, while driving through the woods, if a flock is "flushed" a few may be killed by kicking about in the bushes where they are seen to alight, but I personally am not partial to this method of quail hunting, as I am always afraid that I might kick a rattlesnake instead of a quail. It is well to take a good dog with you from the North, as well-trained dogs are very scarce in Florida. A fast dog that ranges well is the kind most adapted to quail hunting in Florida, which is usually done from wagons or on horseback. When a wagon is used it is driven slowly through the "flat woods" until

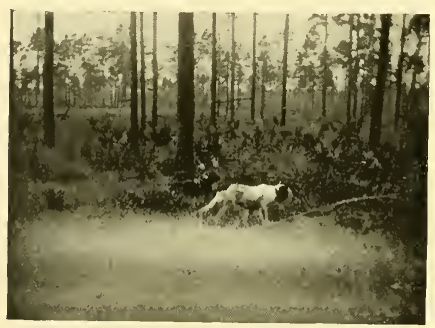
the dogs, who cover the ground well and "range wide," as it is called, find a covey of birds. Then the hunter, leaves the wagon, shoots what he can out of that covey, and drives on to seek for another.

In the old days Sanford was not in existence, and a little town called Mellonville (located a short distance south of the present site of Sanford) was the only town on the west side of the lake. A line of steamers was then running from Enterprise up the St. John's River, passing through Lake Jessop and Lake Harney to Salt Lake and part of the time beyond that as far as Lake Poinset, but the line was discontinued years ago.

Quail and snipe are still abundant along the shores of the upper St. John's in favorable localities, and in past years alligators were numerous, but these last have nearly all been killed off. Of course a few are left, but they are very shy, and a large one is of rare occurrence.

Deep Creek, which was at one time a famous turkey country, joins the St. John's River near where it enters Lake Harney, directly opposite what is known as Cook's Ferry.

The bass fishing near Lake Harney and on Lake Jessop has 
always been excellent, and is probably so still, although the shad fishers, who of late years have been using a seine near Lake Munroe, have injured the fishing to some extent. Bass have been taken from Lake Jessop which weighed over thirteen pounds, and there is a record of one being caught in a small lake in Northern Florida which weighed nineteen pounds. Of course these are the Largemouthed Black Bass, and not its Northern congener, the small-mouthed species.

The St. John's River is usually navigable as far as Salt Lake, but above that it is often choked with floating water plants. Occasionally a small boat can go nearly to Lake Washington, but beyond

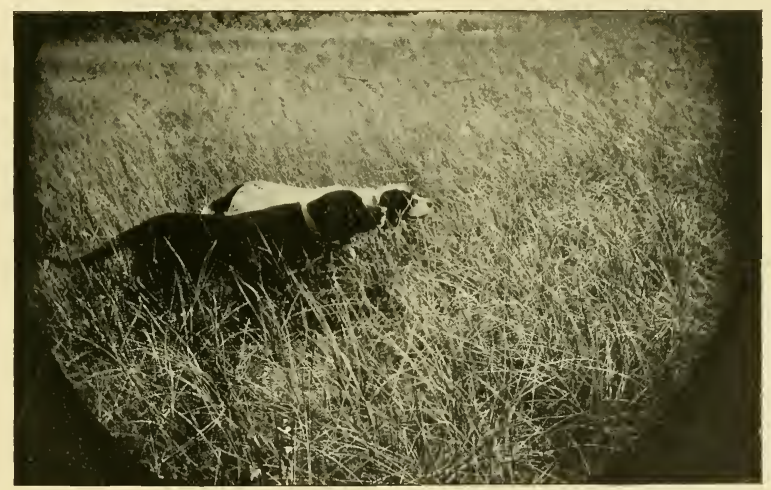

ROBIN AND PRINCE.

Lake Poinset it is difficult to force a passage through the water plants, which are so rarely disturbed that they grow in a mass very difficult to penetrate.

Above Lake Jessop, on the prairies bordering the river, snipe shooting is particularly good at some seasons, and all through the country between St. John's River and the Indian River quail and snipe are abundant in the season. A few ducks may nearly always 
be found along the St. John's River and in and about the small lakes which abound in the interior.

Following down the coast from Jacksonville, we come to the wellknown shooting grounds near Oak Hill, although, as I have remarked before, any one desiring to simply hunt quail and snipe may get fair sport at almost any of the small towns on the line of the road.

At Oak Iill there is a small hotel kept by Frank Sams, who is also the proprietor of the hotel at New Smyrna. Oak Hill is situated

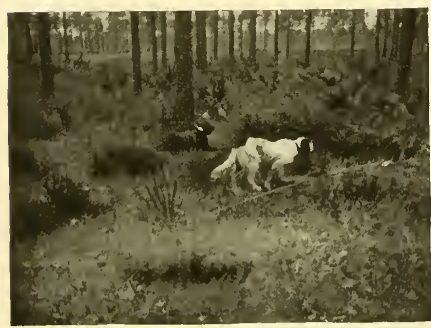
at the head of the Indian River, and fine duck shooting may be had there at times. Deer may also be killed in this vicinity, although they are not as plenty as formerly. There are parts of the old Turnbull Swamp where turkeys are still common enough, but difficult to get at, and one or more bears are usually killed by hunters from Oak Hill in and about the swamp during the season.

The country below Oak Hill on the east coast is the property of the Canaveral Shooting Club and is not open to the public. Ducks are numerous, as bears were also at one time, but I have assisted in reducing their number considerably in that locality.

From Titusville southward there are many places on the Indian River where good duck shooting may be had. In the vicinity of the Ten Thousand Islands the duck shooting is sometimes very good.

At one time ducks came in great numbers to pass the winter on the east coast of Florida, attracted there by an abundance of their favorite food. A bag of one hundred birds in a day's shooting over decoys or "stools" was not uncommon. I must plead guilty to having done this myself on one or two occasions, but none of the birds were wasted, and I am glad to say that I have many times killed 
twenty-five or thirty ducks in a couple of hours and stopped shooting when I could easily have killed many more than one hundred had I desired to do so. Early in the season, when the ducks first arrive, immense numbers are killed by the "pot hunters," who use heavy guns and shoot into the flocks when bunched together in the water. Of course such continual slaughter must necessarily reduce the

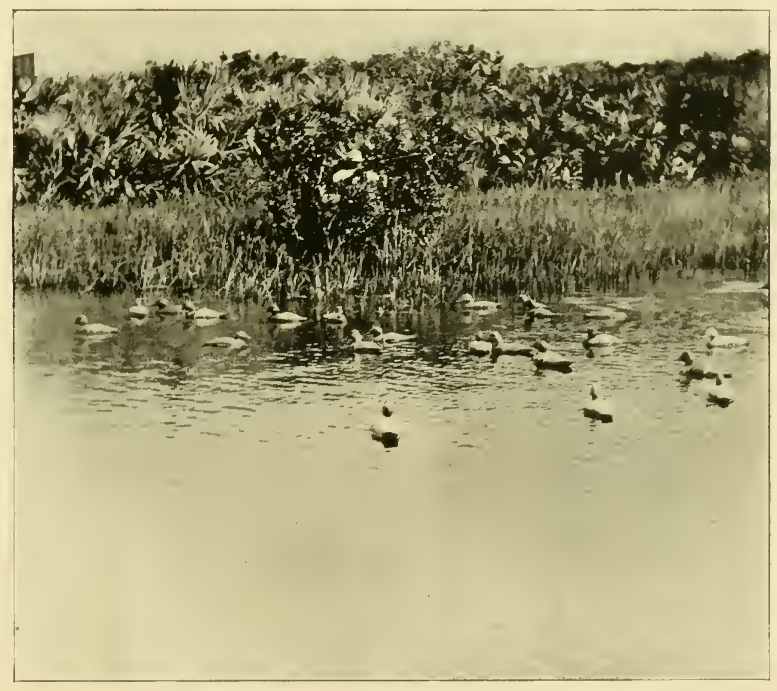

DUCK SHOOTING WITH DECOYS.

number of ducks which annually visit Florida, and already it is evident that their numbers are materially lessened, although they still return, each year, in vast numbers. At some of the small Indian River towns it was by no means unusual to see large flocks of ducks "bedded" within a short distance of a wharf, where shooting was prohibited. They soon learned that they were safe there and paid no attention whatever to the people who stood and watched them 


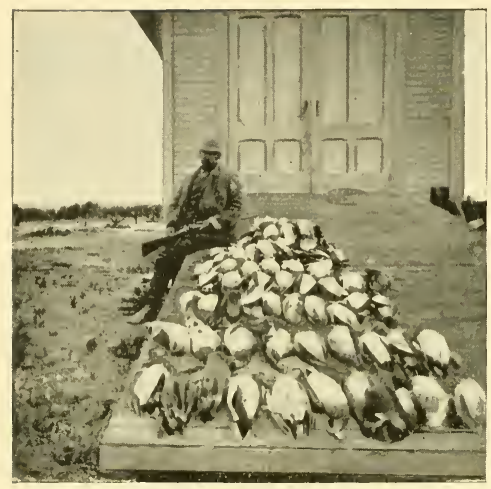

A BIG BAG.

from the shore within easy shooting distance. But those same ducks, when out on the river, would not allow a boat to approach within gunshot of them.

The most common species of duck on the Indian River is the Bluebill or Blackhead, but "there are others." The Widgeon and Pintail are abundant, and the Shoveller, Blue and Green-wing Teal, Ringneck, and Ruddy Duck are also common. Gadwells and Black Ducks (both Northern and Florida) are not uncommon in places, while various other species occur more or less commonly, according to the severity of the Northern winter.

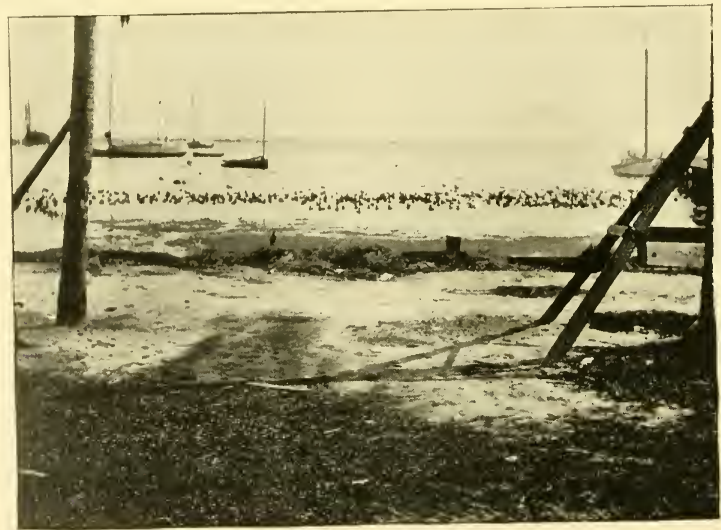


Along the beach between Indian River and the ocean is a particularly fine hunting ground for bears. They are common in many localities, but trained dogs are required to hunt them successfully.

A few deer also occur in that country, but for deer it would be better to go into the interior, and one can nearly always get a guide at any of the smaller towns. Ten miles from the north fork of the St. Lucie River was at one time a particularly noted hunting ground, and during my first visit to that locality game was very plenty. It was at St. Lucie in 1885 that I had my first experience with what is known in Florida as a shooting match, where the prize

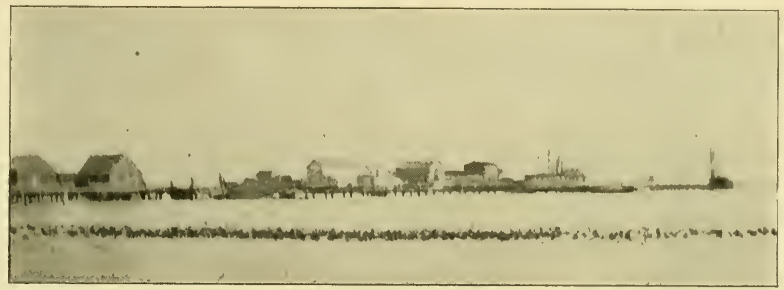

WILD DUCKS.

is a bull or cow, which is rounded up and driven in from the "bush" for the occasion. "Alligator" Jim Russell was a particularly noted character at this time, and was also considered a very good shot. He and the Payne boys and two or three others, whose names I have unfortunately forgotten, took part in this contest.

Each contestant paid a dollar to the owner of the animal and was allowed five chances. The target was a piece of bark fastened to a tree, about one hundred yards distant.

We first competed for choice of the "hind quarters," each man shooting once and the one hitting nearest the center of the bull's eye being adjudged the winner. We then tried again for the remaining hind quarter, and again for the choice of the fore quarters, 
and so on, the last and fifth prize being the hide and tallow. " Alligator" Jim Russell was the life of the occasion, discoursing upon the great numbers of enormous alligators he had killed and the wonderful shooting he had done; but on this occasion his wonted skill failed him, and the writer succeeded in winning three of the

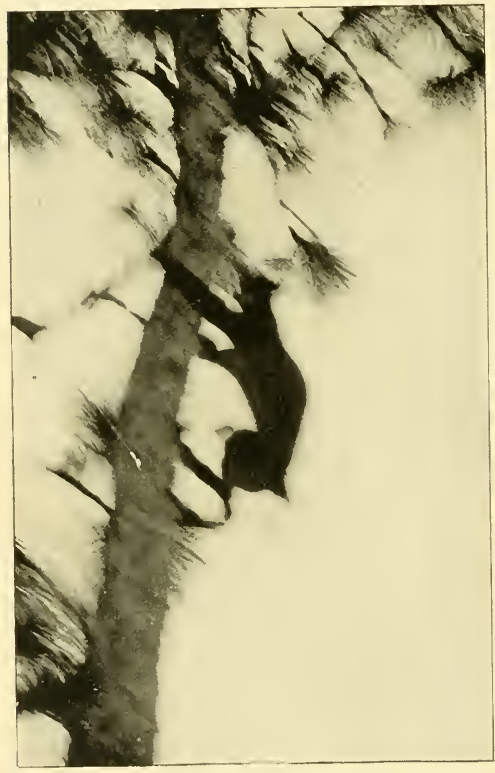

WILD CAT CLIMBING A TREE. four quarters, so that our boat had fresh "beef" (forgive me, thou shades of Chicago bovines,) for several days in consequence.

There is at times very good fishing at Indian Inlet, which is nearly opposite Fort Capron, and the long, narrow, sandy peninsula which separates the Indian River and the ocean is covered with palmetto scrub and scattered hummocks in which small game (and large, also, for that matter) is abundant in places, but of course one must know the country to have good sport.

Turkeys are not found on the peninsula, but bears, deer, and an occasional panther may be killed by those who "know how" and are willing to work. Small game, such as wildcats, coons, and opossum, are very numerous. I do not, as a rule, allow my young hounds to run wildcats, but occasionally, when other game was scarce, I have put the older dogs on the track of a cat to give them a run. Cats have a habit of running in a circle, going over the same trail again and again, unless they are hard pushed. Some- 
times they run straight for a long distance and $\mathrm{th} \in \mathrm{n}$ take to a tree. At other times, especially in South Florida, they often do not attempt to $\mathrm{climb}$ a tree at all, and I have killed a number of cats on the ground where the dogs had run them into a thick place, sometimes directly at the foot of a large tree, when they
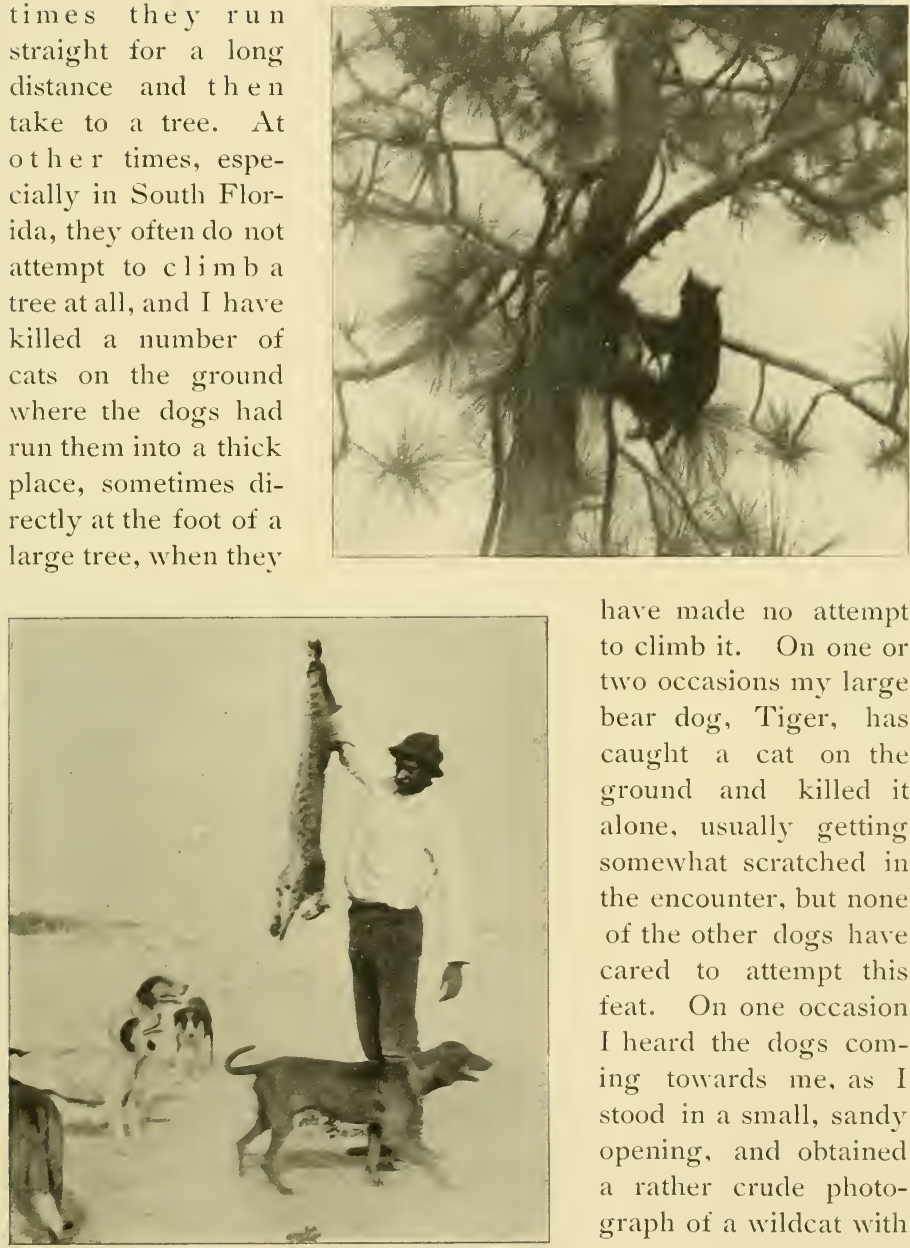

have made no attempt to climb it. On one or two occasions my large bear dog, Tiger, has caught a cat on the ground and killed it alone, usually getting somewhat scratched in the encounter, but none of the other dogs have cared to attempt this feat. On one occasion I heard the dogs coming towards me, as I stood in a small, sandy opening, and obtained a rather crude photograph of a wildcat with

WILD C.IT. 


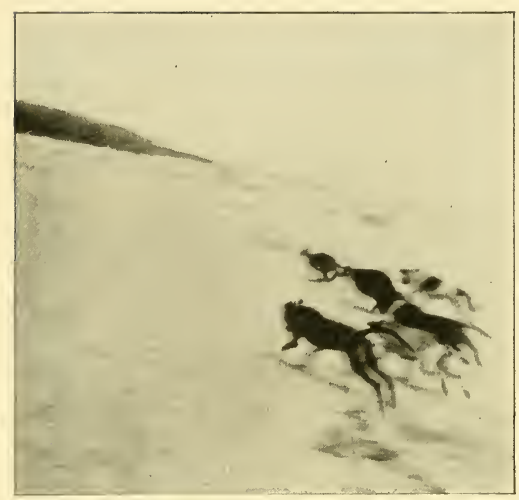

AFTER A WILD CAT. the dogs in full chase as she passed me in the open.

Coons are very numerous, but usually only wander about at night, although I have occasionally seen them on the edge of the mangrove swamps in the daytime. Young dogs often find them while hunting for other game. A coon will climb a tree when he has a chance, if he hears the $\operatorname{dogs}$ near him; but sometimes he is

not quick enough. I have seen good-sized coons run up a small bush when closely pressed and no large trees were handy. On one occasion the bush was not high enough to be out of reach of the dogs, and they soon had him down. Another time the $\operatorname{dogs}$ discovered two coons in a small open prairie, and for a few moments they had a lively time, as a full-grown coon knows how to bite and is a good fighter.

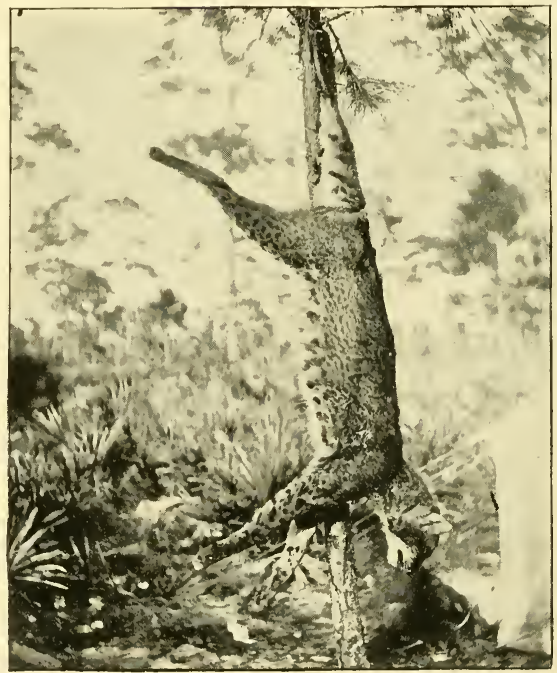


Opossums are common ahmost everywhere, but they are rarely seen, being nocturnal in their habits, although I have occasionally found one in the wo ods in the daytime. They move aw ay very slowly, a n d if touched will curl themselves into a ball and play dead . They are rather ugly little beasts, however, and can

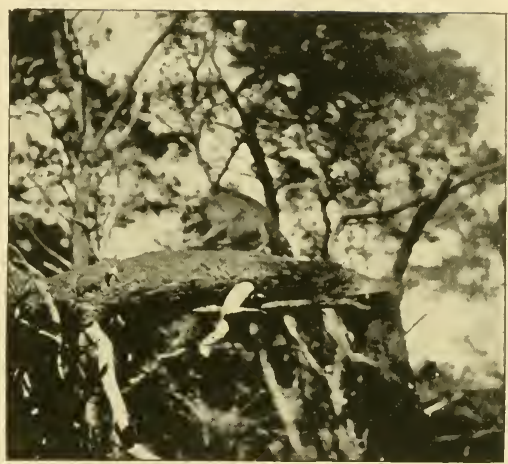

RACCOON. less enough to give them a chance, although they may be held up by the tail and will keep perfectly still, "playing 'possum," as the old saying is. Opossums are a nuisance to any one who

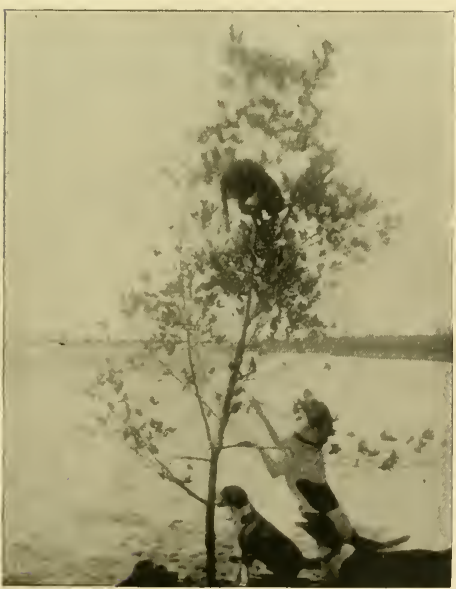

RACCOON. desires to catch specimens of the smaller Florida rodents, as they are always getting into the traps.

Following the Indian River th rough the Narrows, we reach Jupiter Inlet, noted as a fishing resort, and then a few minutes by train brings us to Lake Worth, known to the Indians by the name of Hypoluxo.

At Palm Beach the fisherman may obtain the finest kind of sport, together with the comforts of a good hotel. At the Hotel Royal Poinciana 


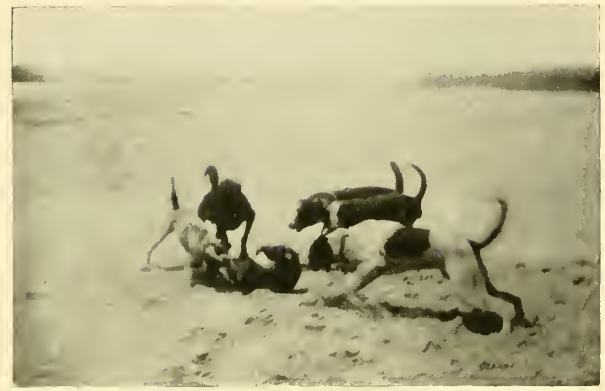

AN UNFAIR FIGHT.

boats and men may be obtained by those desiring either fresh or salt water fishing. The sport, especially for Kingfish, c a $n$ hardly be excelled, as catches numbering as high as 120 fish or more have been taken by one boat in a day. Various other kinds of salt water fish are caught in great numbers, including Bluefish, Spanish Mackerel, Sea-bass, and at times the huge Jew-fish. For Black Bass fishing the fresh water lake west of Lake Worth is of easy access, as a shell road has been built directly to it.

South and west of Palm Beach lies a hunting country "par excellence." Beyond the lake, in the country west of Palm Beach, from Jupiter Creek (Loxahatchee) southward, game is still abundant.

From Lantana, on Lake Worth, one may drive on the country road (which extends to Biscayne Bay) south to Hillsboro River, a distance of about twenty miles, and find good deer shooting in that vicinity. If one desires a camping trip along the Everglades, he should leave the county road about half way to

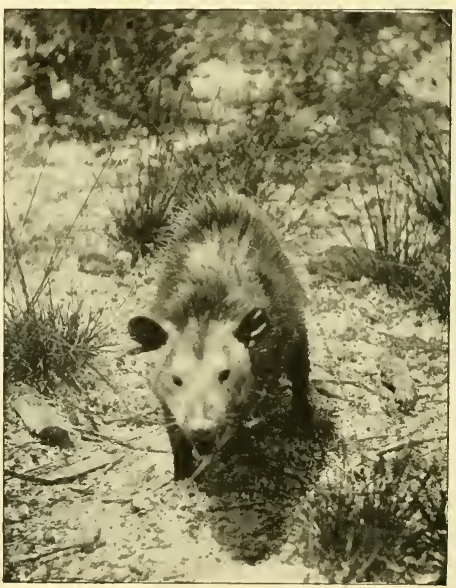

OPOSSUM. 
the Hillsboro River, at a place opposite the government life-saving station. There is an old pump in the road at this place, and Robert Osceola used to camp there a few days every spring while deer hunting. Leaving the road and riding southwest some five miles, one passes between the upper and lower chain of lakes, and this crossing is the only one suitable for wagons for a distance of thirty miles. The swampy lakes are connected by a little creek called Little Fish Crossing. From this point it is less than a mile to the old government trail which runs north, crossing Jupiter Creek

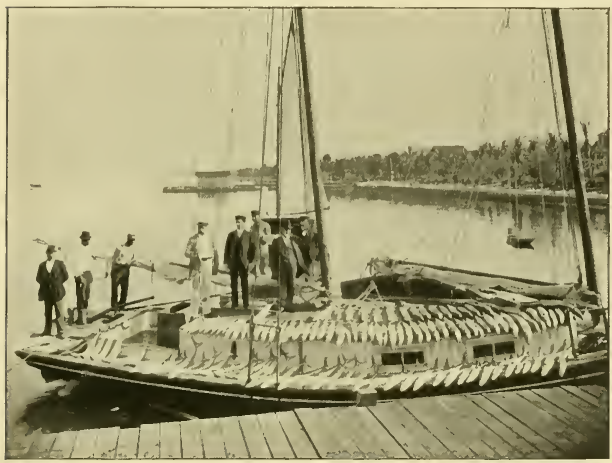

A GREAT DAY FOR KINGFISH.

(Loxahatchee), and south until it joins the county road, about two miles north of Cypress Creek. Old marks of the ax "blazes" may still be seen on the trees, and occasionally a wagon track where some hunter or cat tl edriver has followed the old trail. Sandhill Cranes, turkeys, and quail are abundant throughout this country; but bears are rare and panthers keep themselves to the edge of the Everglades in the heary timber. Parties desiring to hunt this country would do well to have their wagons meet them on the old government trail west of Lake Worth. They could then hunt the country south; coming out on the county road near Cypress Creek. There is only one bad crossing, and that is at the head of the south fork of the Hillsboro River. The country to the west of the old trail is "flat woods " and hummocks, interspersed with cypress ponds, which become more plentiful as we near the Everglades. Many of these ponds are not 
" boggy," and may be crossed anywhere on horseback; but others are not to be trusted. Any pond may be safely crossed in which the low bush grows which, as Jack Davis describes it, "favors a small pine." South from Hillsboro, a distance of about twelve miles, we cross Cypress Creek, at the head of which is an old Indian Camp owned by Osceola, where the Indians build their

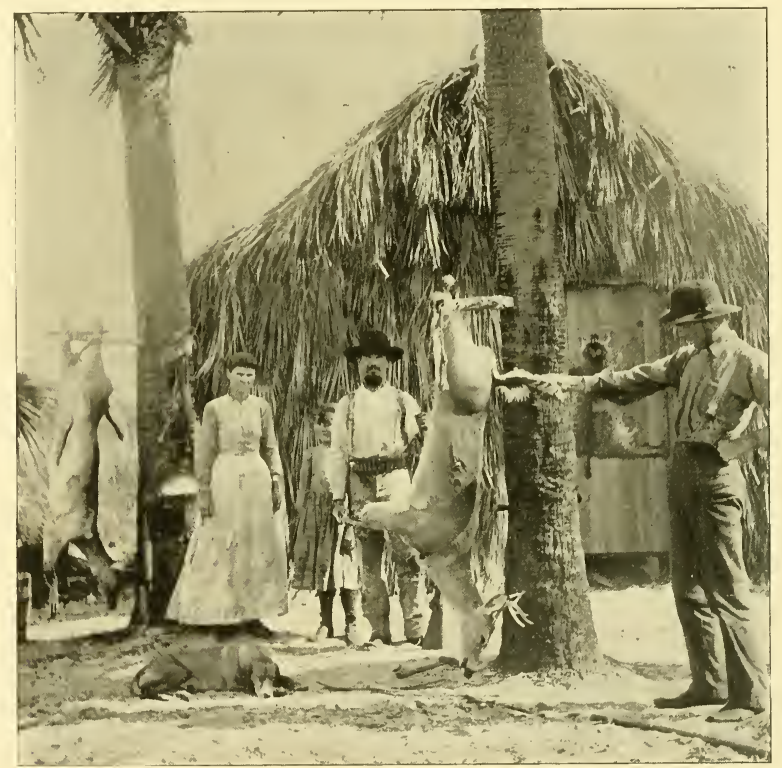

THORNTON'S CAMP, HILLSBORO RIVER.

canoes, the cypress trees in that vicinity being particularly large and fine. Cypress Creek is noted for the abundance of turkeys in that vicinity, and alligators are still numerous in its waters, which may be accounted for by the fact that it is not navigable for boats, being shallow and filled with logs. It also has the reputation of 
being a particularly good location for large rattlesnakes. At times panthers are common here. I have seen the tracks of three panthers made the same night near Cypress Creek bridge; two of the animals crossed the bridge and followed the sandy road for some distance.

From Cypress Creek to Middle River is about four miles. Middle

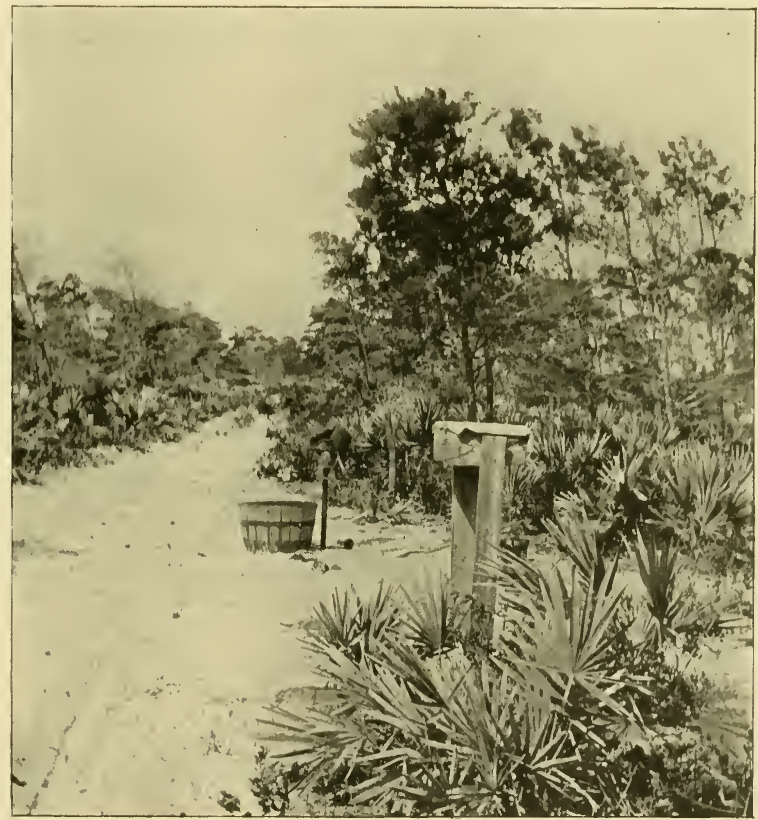

THE OLD PUMP.

River joins Snook Creek about a mile to the east of the county road, and both empty into what is now called New River Sound. From Middle River to Snook Creek is about one mile by the 
county road. The fishing in Snook Creek is very fine at times, as both Black Bass and various salt water species (Snapper, Cavalier, etc.,) are numerous. Three miles south from Snook Creek by the county road we reach New River, where one finds a comfortable camp owned by Mr. Frank Stranahan, and usually passengers bound for Biscayne Bay stop over night at this point. The canal has lately been completed as far as New River, and the railroad will

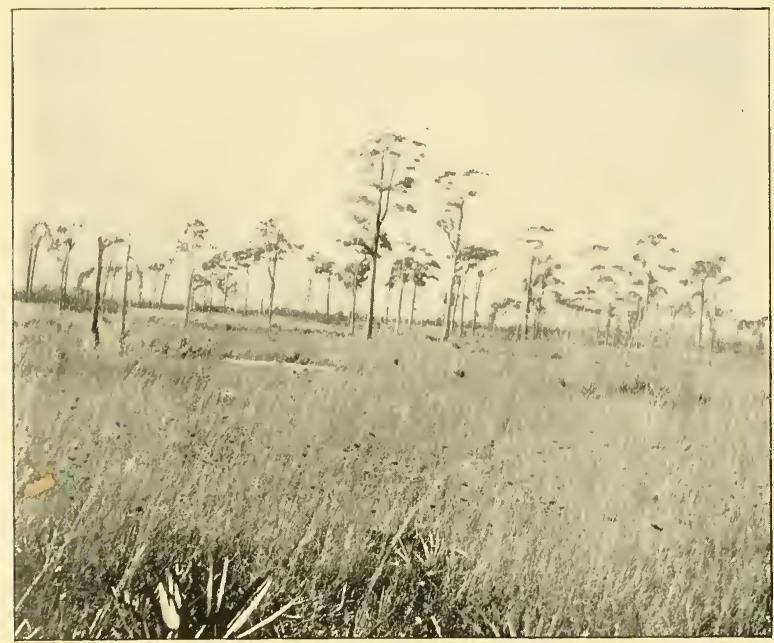

THE EDGE OF THE EVERGLADES.

next year be extended to Biscayne Bay. At present a stage ride from Lantana to Lemon City, Biscayne Bay, occupies nearly two dars. When the railroad is finished the trip may be made in two hours. These improvements, which will make the country so very easy of access, will have a decided influence on the hunting and fishing.

New River (New-la-pee) flows east and enters into New River 
Sound, which, in turn, opens into the ocean five miles farther to the south. New River is very deep in places and is one of the best localities on the coast for manatee. It is the farorite huntingground of the Indians when they desire to kill one of those ani-

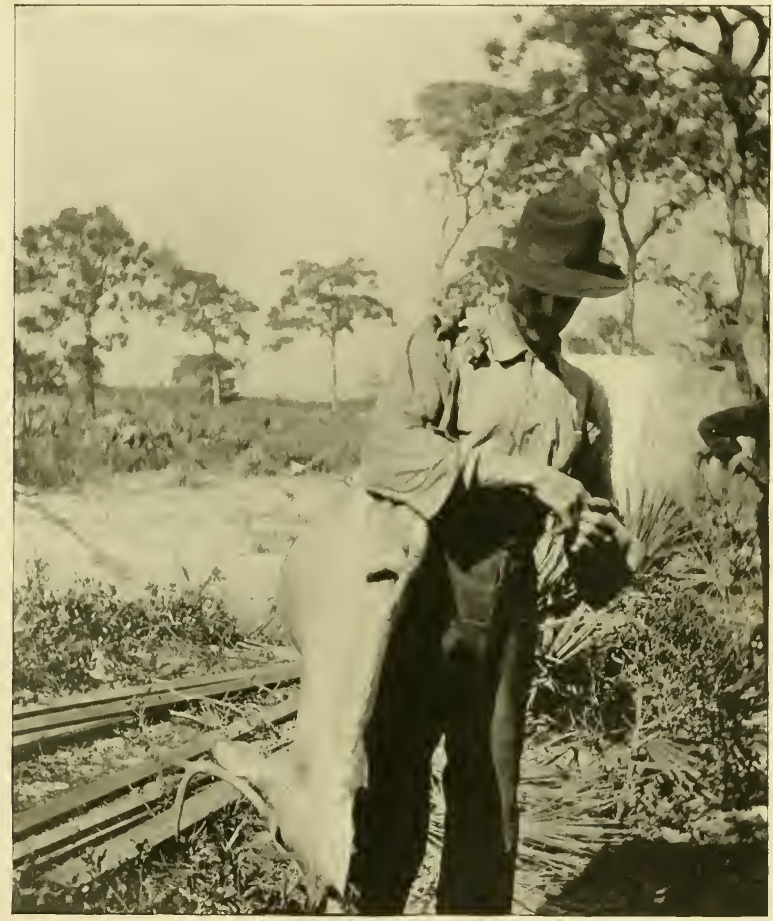

JOHN DAVIS.

mals. Several of the Indians have permanent camps on New River. Tom Tiger, Robert Osceola, Jumper, Old Tom, Old Charlie, and Tom-a-luske all have camps there. In the upper 
north fork of the river fine bass fishing may be had, and there are usually a few ducks about, but there is very little else in the way of game, deer and turkey being scarce in that vicinity.

Continuing south from New River, again following the county road, a drive of thirteen or fourteen miles takes one to Snake Creek (Car-chee-pap-kee) : then comes Arch Creek (Char-to-fee-na),

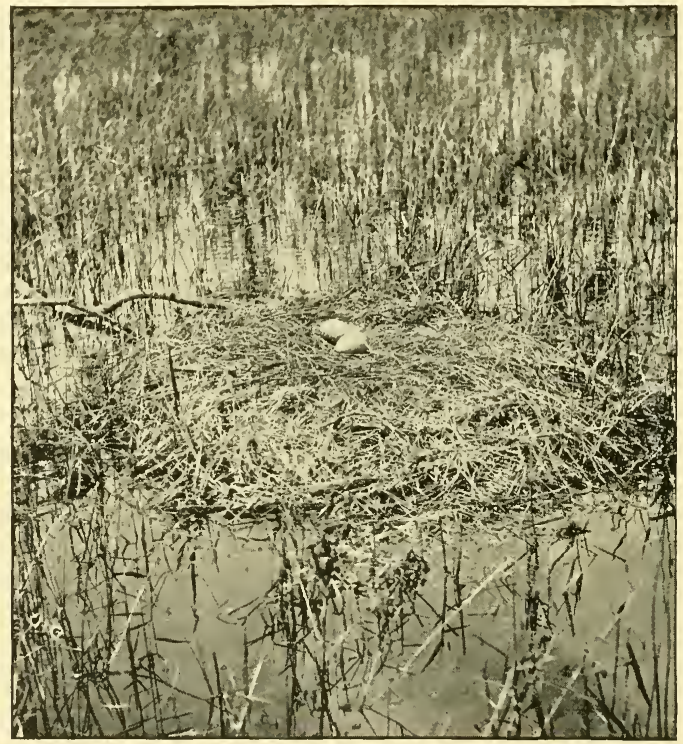

A SAND HILL CRANE'S NEST.

and next Little River (She-la-coo-ho-co-chee), which is about twenty-four miles from New River, and about a mile from Lemon City on Biscayne Bay.

There is very little game in this country except quail (and ducks in some places), which are common enough, but the country is not 
one which gives promise of much sport in the way of large game hunting.

After passing Snake Creek the country becomes high and rocky, and one begins to notice a variety of butterflies which have not been seen before, and in the hummocks through which the road passes pretty yellow and white tree-snails are not uncommon.

The country between Lemon City and Miami is high and rocky. Quail are abundant, and ducks are numerous at certain seasons in

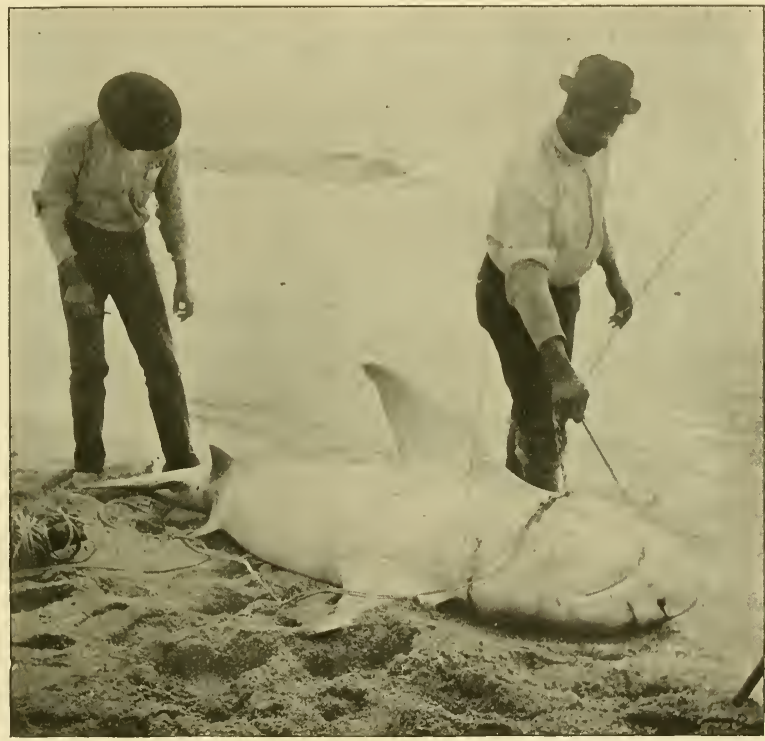

DEAD SHARK, NEW RIVER INLET.

Dumbfoundland Bay and Indian Creek. This creek was at one time a favorite resort for crocodiles; but they have lately become shy and are rarely seen. 
The Miami River, which runs from the Everglades into Biscayne Bay, is probably the only river in Florida which has a fall or rapicl worthy of the name. For about a half a mile at the head of this stream there is considerable fall. At this point the river is shallow and not navigable for boats, and has a very rapid current, in which "Cavalia" (Caroux hippus) are numerous and may be taken with an artificial trout fly. At the head of the Miami River the great Everglade swamp opens out before one like an immense, shallow, grassy lake. Throughout the Everglades numerous islands, large and small, are scattered about. Some of them are several miles in extent and

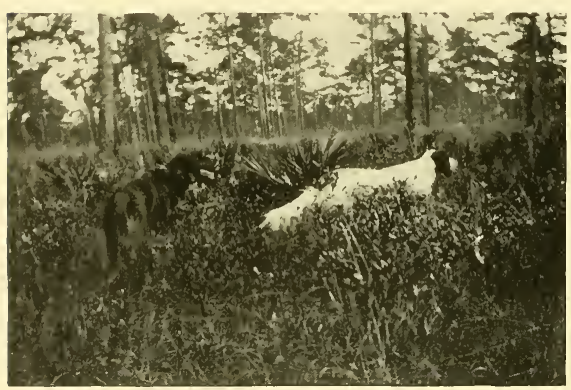
very fertile, but, luckily for the Indians, they are very difficult of access, which has prevented them from being occupied by white men up to the present time. In the fall the water in the Everglades is high enough to allow the use of canoes and small boats, but in winter and spring it gradually lowers until boat navigation is difficult, and in many places impossible, and the character of the ground is such as to render it useless to attempt any other means of locomotion.

The Indians go from the east coast to the Big Cypress Swamp during the summer and fall in their canoes. This can only be done when the water is high and under the guidance of a person who thoroughly knows the country.

From New River to Biscayne Bay and the southern end of Florida there are several good men, able to guide a hunting party, and who know the country well. Among them may be mentioned William Freeman, who lives at Little River, about a mile from Lemon City. 
For the country between New River and St. Lucie River, and, in fact, including the Biscayne Bay country, there is no better guide than John Davis, who has lived almost his entire life in the woods, and is

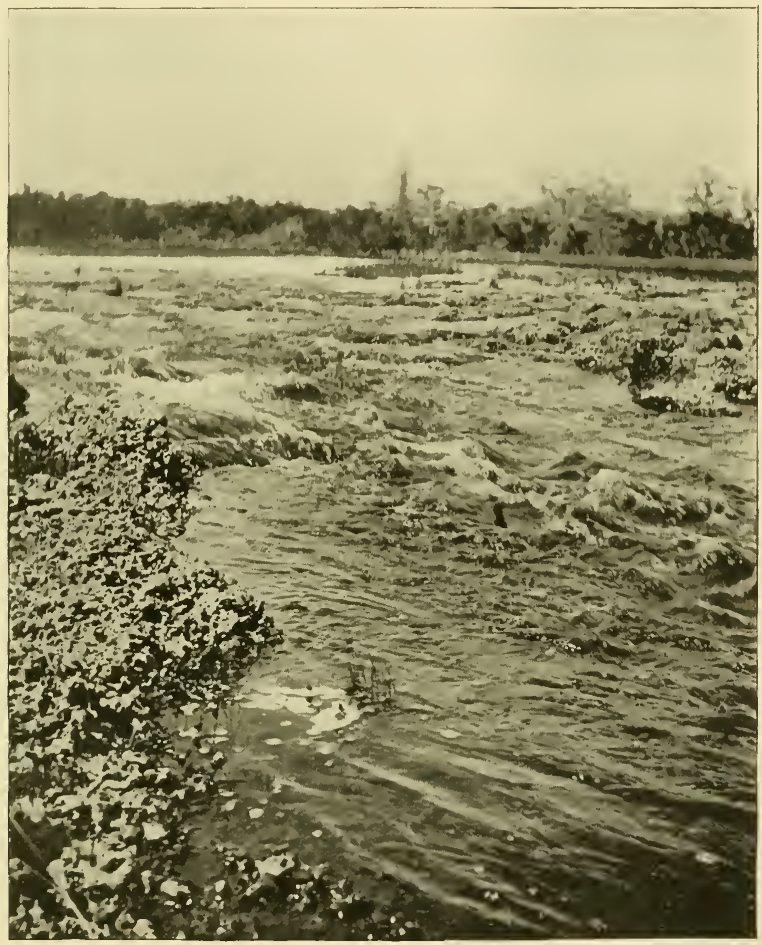

THE MIAII RIVER RAPIDS.

one of the few real hunters and trappers who could be called a thorough woodsman. Where the county road crosses the Hillsboro River, the only settler in that vicinity, by name William Thornton, is 
sometimes willing to act as guide for parties who desire deer hunting, and last year he had one or two fair dogs.

While on the subject of hunters I cannot leave out my old hunting

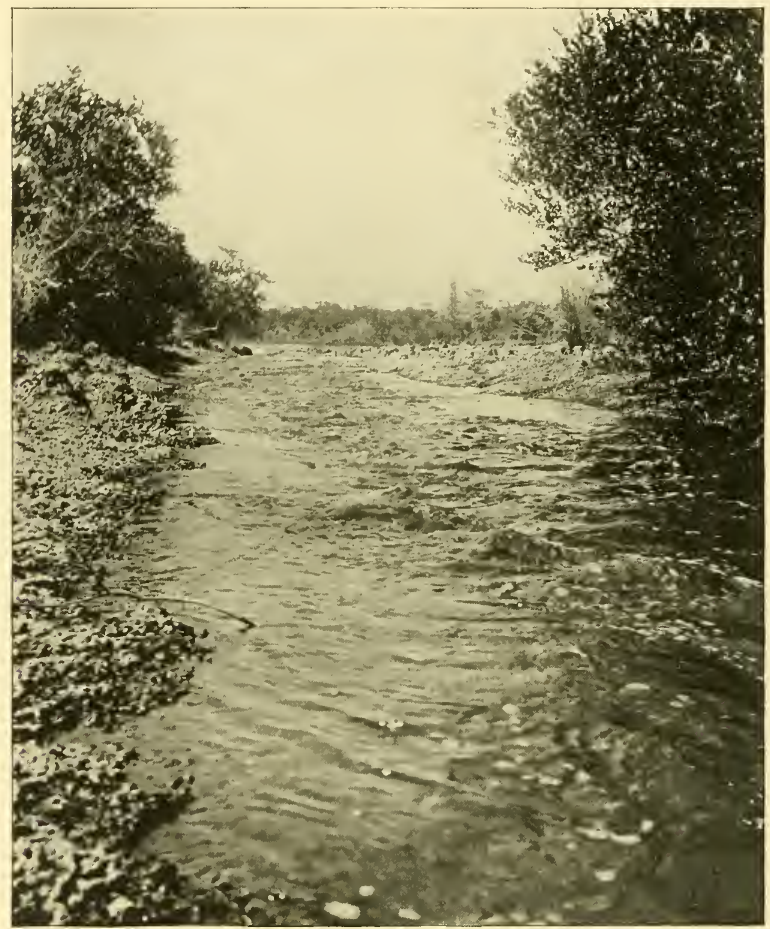

MIAMI RIVER.

companion, Mr. O. A. Quartermain, who is, in my opinion, the best hunter on the Indian River, and his record of fifty-one deer and fourteen bears in one season is a hard one to beat. Of late years 
he has done but little hunting, and at present has charge of the lifesaving station at Chester Shoals, Fla.

On the keys about Biscayne Bay beach birds are numerous, and

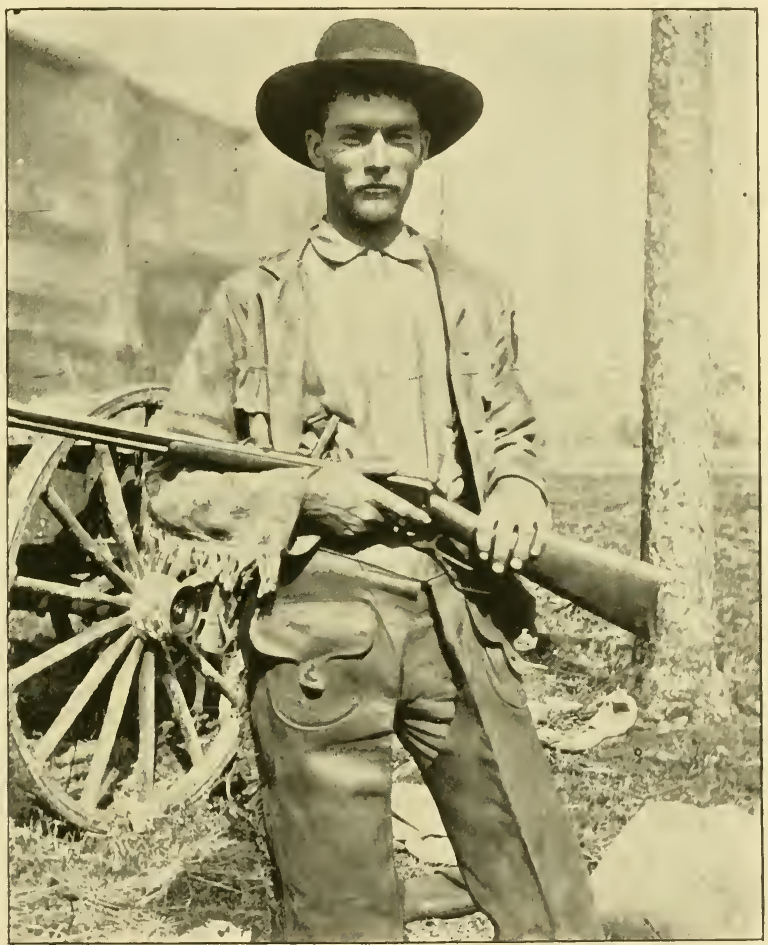

JOHN DAVIS.

quail are abundant in the pine woods. The birds are plenty enough, but the rocky country is a bad one for dogs. The fishing in Biscayne Bay, or in its vicinity, is particularly fine, and just outside the 
bay among the reefs is probably one of the finest fishing grounds on the Florida coast. Tarpon are abundant in the bay and run up many of the rivers. Of course the Tarpon is the king of all Florida game fishes, and phlegmatic indeed must be the man who does not feel a thrill of excitement when the magnificent fish hurls himself completely out of the water again and again, shaking his head savagely in his frantic efforts to dislodge the hook. May and June are the best months for Tarpon fishing; but good sport may be had in April and sometimes in March, and a few fish are taken during the winter months by patient and enthusiastic fishermen. Tarpon are numerous in Biscayne Bay, and very fine fishing may sometimes be had at Steamboat Creek at the south end of the bay.

All kinds of fishing may be had in and about Biscayne Bay. Kingfish are unusually abundant : perhaps the very best place for Kingfish is near the black and white channel buoy off Cape Florida. For those who enjoy bottom fishing and want large fish and plenty of them, I would advise them to try in the vicinity of Alligator Reef Lighthouse, where the fishing is most excellent.

Crocodiles are to be found in Biscayne Bay, but in most cases they are very shy and difficult to shoot. Continuing farther south from Card Sound into Barnes Sound, crocodiles are more numerous and not nearly so shy. From Cutler going south, the road, if it may be called one, is very bad, and one enters a country which is rarely visited by a white man. It is rocky pine land, bordered by a low and wide marshy prairie and occasional mangrove swamps. In these prairies deer are abundant and very tame. They are rarely hunted, as but few white men have ever been in this country, and it is too far away from any settlement for an Indian to carry out game to sell.

Deer are numerous and wolves commence to appear in some places east of Whitewater Bay. A few panthers wander about this country, but they are not numerous. In some of the ponds and marshes alligators are plentiful, and many of them are large, as that country is seldom visited by hunters. Deer and bears were at one time common on the larger keys, but there are few left on them now. 
Southeast of Cape Sable is about the only place where flamingoes still exist in Florida in any numbers, and a colony or two of them breed there every year. This is a country very difficult of access, and the bircls are very shy and are rarely seen, much less killed.

On the Bahama Islands, only a short distance from the Florida coast, there are colonies of thousands of flamingoes, and their eggs are gathered in numbers by the inhabitants. It is probable that the Florida contingent is occasionally reenforced from the Bahamas, although the bird was at one time undoubtedly common in Florida. Water-birds are abundant about some of the keys. A few pelicans, cormorants, gulls, and man-o'-war hawks may be seen almost any time. as well as ducks and an occasional heron.

In some places on the west coast game is very abundant. We hear of the abundance of game in the country about the Steinhatchee River : but I know but little of it personally and cannot vouch for the truth of the statement. From Cedar Keys southward there is plenty of game, but the country is rather difficult of access. Near such well-known places as Homosassa and Tarpon Springs deer and turkeys are numerous in some localities: but they do not come out of the woods and wait to be killed, and one has to have a guide who knows the country, as well as properly trained dogs, to insure a successful trip.

Tampa has grown to the dignity of a city, and naturally large game has been driven back, but fine bags of quail and snipe are made by the guests of the hotel, and guides and dogs are furnished those desiring to indulge in the sport. Arthur Schleman, who is at present located at Tampa, owns several dogs and knows the country about 'Tampa.

There are several small rivers near Tampa, and fair shooting may sometimes be had. An occasional deer and turkey still linger. Alligators are also to be found, but, as in other portions of Florida which have become settled, they are not numerous and are very shy. Good fishing may be had within a short distance of Tampa by those who care for it. For Tarpon, one must go farther south to get good sport, and it should be borne in mind that nowhere is the Tarpon 
fishing really good until quite late in the season. Occasionally goodsized fish are caught during the winter months, but it is well known that Tarpon do not bite well until the warm weather sets in. A good many Tarpon have been caught near the mouth of the Caloosahatchee River and above Fort Myers near Beautiful Island.

I have enjoyed good fishing at Captiva Pass opposite Pine Island; here Tarpon are sometimes very numerous and other kinds of fish are plentiful enough. South of Ostero Bay at Big Hickory Pass is one of the best fishing grounds in Florida, and several men have had excellent fly fishing at this point. Mr. George Mixter, of Boston, Mass., was kind enough to give me the following list of the species he has taken at Hickory Pass, using a large silver-bodied fly : -

Sea-trout (Cynoscian maculata).

Redfish or Channel Bass (Sciocna ocellata).

Cavalia (Caroux hippus).

Rovallier or Snook (Antropomus undecimalis).

Spanish Mackerel (S. maculatus).

And I believe he has since taken others.

The huge Jew-fish (Epencphclus nigritus) is common about Ostero Bay, and in Surveyor's Creek Tarpon are numerous in their season.

At Big Shark River Mr. Mixter tells me he succeeded in making a very small Tarpon take a fly. He used a large silver-bodied specimen and fished during the flood tide, which at that point runs like a mill-race.

For those who are devotees of the harpoon, the great Devil-fish (Manta birostris) and the various sharks will afford them all the sport in that line they desire.

Probably the finest food fish in southern waters is the Pompano (Trachinatus ornatus), which is very numerous along the coast of Florida, but which is rarely taken with hook and line except at Key West, where, curiously enough, it is often taken in that manner.

Some years ago the writer made a trip from Fort Myers up the Caloosahatchee River into Lake Okeechobee, Fish-eating Creek, and other places, and then continued on up the Kissimmee River to 
the town of that name. The country in the ricinity of Lake Okeechobee was at that time filled with game.

Deer, turkeys, cranes, and alligators were very numerous. Quail and snipe were to be had in numbers, although they were as not plenty as they are sometimes farther north, in the country about Lake Kissimmee. Ducks were not numerous and were confined to two or three species.

Southeast from Fort Myers about seventy-five miles, lies the Big Cypress Swamp, which is the hunting ground of the Seminole Indians. This is to-day one of the best localities in Florida for all kinds of large game. The advent of the white man is not looked upon with favor by the Indians, and they do not encourage his presence in what they believe to be their country. The best way to get to the Big Cypress hunting grounds is by wagon from Fort Myers: but I am informed it may also be reached by going up the Chockeloskee River as far as it is navigable by boat and then making a "carry" of about three miles. I have never made this trip and cannot vouch for the accuracy of the information.

After the middle of April the mosquitoes become very troublesome on the Keys: but the weather is most delightful, and the fishing improves with the warm weather. Northwestern Florida is rarely visited by the sportsman, but those who have hunted in that portion of the State claim that game is abundant. Ducks and beach birds are at times plenty in the ricinity of St. Joseph's Bay and also about Santa Rosa Island and Pensacola Bay. Turkeys and deer are claimed to be very abundant in some of the counties to the north of Cedar Keys, but they are rarely visited and there is little accommodation for the traveler. At present such fine shooting may be had in places easy of access that there is little to tempt one to explore these out-of-the-way localities; but a day will come when Northwestern Florida will have to be sought by the hunter who desires good sport.

In the vicinity of Tallahassee the country and climate is delightful, and fair quail shooting is to be had within driving distance of the city. Farther to the west. however, deer and turkeys are 
IOS

HUNTING AND FISHING IN FLORIDA.

numerous. On one occasion, when stepping off the train near Mossy Head, I saw several wild turkeys offered for sale by some negroes, who claimed they were very common, and also that deer were plenty in that part of the country. 


\title{
THE MAMMALS OF FLORIDA.
}

\author{
Family FELID.E. The Cats. \\ FELIS CONCOLOR FLORIDANA Subsp. Nor'. \\ Panther, Cougar, Puma.
}

Not uncommon in the unsettled portions of the State.

The Florida Panther is apparently separable, at least, subspecifically, from its more Northern congener, which it resembles in general marking, but differs in being more rufous or reddish brown in color, and in having the legs relatively longer and the feet decidedly smaller.

A most noticeable character in the Florida animal is the small size of the foot. Several Northern examples which I have examined have the foot at least four inches broad, while those of a Florida specimen of equal size would not exceed three inches.

A female which I killed in April, I 895 , measured about seren feet from nose to tip of tail, and her forefoot measured two and seven eighths inches in width. In a Colorado specimen of about the same length the foot measured four and one eighth inches at the widest part, and another specimen three and seven eighths inches. *

It is rare that a Florida Panther exceeds nine feet in length, although it is claimed that they occasionally grow larger. Both Maynard and Chapman mention hearing of a large, spotted, longtailed cat, and suggest the possibility that it might be Felis onca. I have never met with an Indian who had seen or heard of such an animal. There is, however, an animal still living (or he was in April, I895,) in Florida, whose tracks are at least a third larger than any Florida Panther I have ever seen.

However, if he is ever killed (and I hope to sometime see his

- A young Panther cub is tawny brown in color, marked with numerous large, irregular, brownish-black spots. The cry of the cub resembles the screech of a Parrot, but it often utters a soft whistle. The cry of the old Panther somewhat resambles the screech of a Parrot, but is much louder. 
snarling face over the sights of my rifle), he will probably prove to be a very old and unusually large male Fclis concolor floridana.

Panthers kill many small mammals, as well as deer, when they can get them. They are very fond of hogs, and a good place to look for a panther is in the vicinity of some drove of semi-wild pigs. When once a panther becomes a " pig eater" he prefers pig to any other kind of food.

\section{LYNX RUFUS FLORIDANUS (Raf.). \\ Florida Wildcat.}

Common. Some specimens are large and spotted on the sides and flanks, and are more rufous than Northern specimens. I have killed one old male which measured forty inches from tip of nose to tail, and stood twenty inches high at the shoulder.

\section{Finmer CANide. The ITolves and Foxes. CANIS LUPUS GRISEO=ALBUS (Limn.). Wolf.}

Still not uncommon in some localities. In the ricinity of the Big Cypress and in extreme Southern Florida wolves still occur in some numbers. A wolf was seen in the spring of I 895 near Little Fish Crossing, southwest of Lake Worth. They are usually black, although examples have been killed which were brown, shading into gray on the belly and breast.

I have heard of gray wolves in Florida, but have never seen one. Robert Osceola killed a female with two cubs near the Big Cypress in the spring of $\mathrm{I} 89+$. He captured the little ones alive and took them to his camp: but they would not eat, and, after keeping them a clay or two, he killed them. The mother and both pups were black.

\section{UROCYON CINEREO -- ARGENTATUS (Mull.).}

\section{Gray Fox.}

Common. Florida foxes are somewhat smaller and graver on the back than those found farther north. 
Famil MUSTELID.E. The Weasels, Skunks, etc.

\section{PUTORIUS ERMINA PENINSULAE (Rhoads.).}

Florida Weasel.

As far as I am aware but two examples of this interesting mammal have as yet been recorded from Florida, one from Pasco County (the type), and the other from Gainesville, by Mr. Chapman.

\section{LUTREOLA VISON (Schreber).}

Mink.

Probably not uncommon, but rarely seen. I have specimens taken near St. Augustine, and Mr. Maynard gives it as "very plenty on the coast near Cedar Keys," and states that he saw one at Blue Springs.

\section{LUTRA CANADENSIS (Scheber). otter.}

Still very common in some localities, but becoming less so every year.

\section{MEPHITIS MEPHITICA Baird. Common Skunk.}

This skunk seems not to be uncommon in Northern Florida : it is rare as far south as Titusville, and the Indians claim it does not occur south of New River. Some specimens are comparatively small and nearly black.

\section{SPILOGALE PUTORIUS (Linn.). \\ Little Striped Skunk.}

This pretty little species, which is about the size of a kitten, is very common in some localities on the east coast. I found it numerous near Cape Canaveral, and specimens have been taken as far south as New River. Dr. Merriam records a specimen from Kissimmee Prairie (N. A. Fauna, p. 7, No. 9, I89o).

This little skunk is very fond of mice, and it is often tamed and kept about houses for the purpose of clearing them of those animals. In some instances the scent glands are removed, but not always. I am told they soon become very grentle and tame. 


\section{FAMILY PROCYONID,E. The Raccoons. \\ PROCYON LOTOR (Limn.). \\ Raccoon.}

Common. Somewhat smaller and more rusty in color than Northern specimens.

In Florida the raccoon likes swampy places; it is usually common near the seacoast, as it is particularly partial to crabs and fish.

\section{FAMILY URSID.E. ThE BeARs.}

\section{URSUS AMERICANUS Pall.}

\section{Black Bear.}

Most common near the seacoast in unsettled portions of the State. The Florida bear equals and perhaps exceeds in size its Northern relative.

Bears are claimed to have been killed which weighed over six hundred pounds, and I, myself, have shot specimens which would weigh in the vicinity of five hundred pounds. One large male which I did not weigh measured fifty-six inches (tight measure) around the belly, and six feet two and one half inches from nose to tail. This bear was fat and in good condition. One of the claws measured three and one fourth inches, measured on the curve.

The Black Bear hibernates in Florida, as it does elsewhere in the United States, usually remaining hidden from about Christmas time until March. The flesh of a young one is palatable, and the oil is much esteemed by the Indians and hunters, and is used for cooking purposes as a substitute for lard.

Late in the fall bears seek localities where berries of the "scrub" palmetto are abundant, in some seasons. When berries are abundant the bears become very fat. After their winter sleep they wander about a good deal, feeding upon the crabs which they find on the beach and the buds of the mangrove trees, as well as the cabbage of the palmetto palm, and at this season a pig is a welcome addition to their larder. Still later in the season, during June, they hunt the beaches for turtles' eggs, of which they are very fond. 


\section{FAmily CERVID.E. The Deer.}

\section{CARIACUS VIRGINIANUS (Bodd.).}

Deer.

Deer are still very numerous in the less settled portions of the State. The Florida deer is a small Southern race of the Virginia species. A full-grown buck will often weigh less than one hundred pounds, and I have killed yearling bucks which weighed under ninety pounds.

Of course it is not unusual to find considerably larger specimens, but the average Florida deer is small. I have been told that deer have been killed in Northern Florida which would weigh nearly two hundred pounds. The bucks drop their horns about the first of February.

\section{Family MANATID.E. The Manatees.}

\section{TRICHECHUS LATIROSTRIS Harlan.}

Manatee.

The manatee occurs commonly in many of the bays and rivers of South Florida. It lives equally in salt and fresh water, going into the rivers to feed on the grass, and, as some authors claim, the leaves of the mangrove trees.

They were at one time abundant in the St. Lucie River, and a number have been captured alive in that river in rope-nets made for the purpose.

Although of such great size, it is a gentle, harmless animal, very timid and shy. The flesh is much esteemed by the Indians, and also by some of the white inhabitants. The Indians kill a number of them each year in the ricinity of New River. They harpoon them in the rivers or in the ocean near the mouth of some river.

The Florida manatee is very similar to that found in Central or South America, and perhaps should not be recognized as a distinct species.

The manatee grows to an immense size, sometimes attaining a length (it is claimed) of fifteen feet. The skin is very coarse 
and thick and is covered with scattered coarse hairs. When not frightened or suspicious it generally rises to the surface to breathe at intervals of from one to two and a half minutes.

\section{Famil VESPERTILIONID.E. The Bats.}

\section{ARTIBEUS CARPOLEGUS Gosse.}

\section{Leaf-Nosed Bat.}

1. carpolegus Chapman. Bull. Am. Mus. Nat. Hist., p. 3+2, $\mathrm{I} 89+$.

1. perspicillatus H. Allen. Bats N. A., p. 93, I893.

Nose with leaflike membrane: general color ashy brown; expanse of wings, I 2.50 to It.

A single specimen recorded from Key West by Mr. C. J. Maynard (Bull. Essex Inst., Salem, Mass., Oct., I872, p. I +4 , Vol. IV., No. Io), as Artibeus perspicillatus. According to Mr. F. M. Chapman (Bull. American Mus. Nat. Hist., p. 3+I, IS94), the Cuban species is Artibcus carpolegus, Gosse, and not perspicillutus, differing from that species in the absence of conspicuous facial streaks, and in its smaller size.

\section{CORYNORHINUS MACROTIS (Le Conte). \\ Big=Eared Bat.}

Ears very large; fur soft, dark at base with lighter tips: under parts of body pale; expanse of wings, 9.50 to 10.75 .

Recorded by Dr. Harrison Allen (Bats N. A., p. 58), from Floricla, a single specimen having been taken at Micanopy by Dr. Bean.

\section{VESPERTILIO GRYPHUS. F. CuT. \\ Little Brown Bat.}

small: general color brown, showing a tinge of olive in some lights: the basal portion of the fur (concealed) is dark plumbeous: face whiskered; expanse of wing, 8 to 9.25 .

Recorded by Dr. Rhoads (Proc. Acad. Nat. Sci., Phila., I894,) from Tarpon Springs, "Sereral specimens taken." 


\section{ADELONYCTERIS FUSCUS (Beañ.). \\ Brown Bat.}

General color light brown, paler below: expanse of wings, 9.50 to $\mathbf{0 . 5 0 .}$ Common in Florida.

\section{VESPERUGO CAROLINENSIS (Geoff.). \\ Carolina Bat.}

A small, pale-brown bat; expanse of wings, 8 to 9. Probably common. Recorded from the Suwanee River by Mr. Chapman, and from Tarpon Springs by Dr. Rhoads.

\section{NYCTICEJUS HUMERALIS Raf. Twilight Bat.}

Dark brown above, paler below; expanse of wings, 7.75 to 9.50 . Recorded by Mr. Rhoads from Tarpon Springs, and by Dr. H. Allen.

\section{DASYPTERUS INTERMEDIUS Peters. Fulvous Bat.}

A rather large bat, pale tawny brown in color; expanse of wings, I 2 to 13 .

Recorded by Dr. Harrison Allen (Bats N. A., p. I38, I893), from Davenport, Florida.

\section{ATALAPHA BOREALIS (Mull.). \\ Red Bat.}

\section{A. noveboracensis auct.}

1. borcalis Mull. Rhoads, Proc. Phil. Acad. Sci., p. I56, I894.

Fur pale yellowish at base, tipped with reddish brown, and ashy ears not edged with black; expanse of wings, I0.75 to II.75.

Numerous specimens of bats identified as this species have been taken in Florida. Mr. F. M. Chapman records it from Gainesville and the Suwanee River, and Dr. Rhoads obtained specimens from Tarpon Springs which he identified as Italapha borealis tfeifferi (Gundlach); but the Cuban form is brighter colored than the true borealis, while Floricla specimens are darker. 
The Florida form of this bat seems to be entitled to at least subspecific recognition, and several writers have already stated this to be the case, but no one has yet taken the trouble to christen it.

\section{ATALAPHA CINEREA (Beaut.). \\ Hoary Bat.}

Fur dark brown tipped with silvery gray; ears marked with black: expanse of wings, I2.50 to $\mathrm{I}+5 \mathrm{5}$.

Recorded by Mr. Chapman from Gainesville (Bull. American Mus., Nat. Hist., p. 343, I89t).

NYCTINOMUS BRASILIENSIS Is. Geoff.

House Bat.

General color, pale seal brown: expanse of wings, IO to I I.

Common in some localities.

FAMILY SORICID.E. THE SHREWS. BLARINA BREVICAUDA CAROLINENSIS (Bach.). Southern Mole Shrew.

No ears visible: tail short: general color slaty gray, often silvery on under parts. Length of body without tail about 3.50 : tail about.75.

A specimen was taken by Mr. C. J. Maynard, near Miami, and another by Mr. Chapman at Gainesville.

\section{BLARINA CINEREA (Bach). Cinereus Mole Shrew.}

Small: no ears visible: color slaty gray, slightly paler on under parts. Length of body, without tail, about 2.50 ; tail about $I$.

Mr. Chapman states (Bull. Am. Mus. Nat. Hist., p. $3 t^{3}$, I89t), a badly preserved specimen in alcohol from Indian River, is provisionally referred by Professor Baird to this species.

\section{BLARINA EXILIPES Baird. \\ Small=Footed Mole Shrew.}

Small : general color dark slaty gray, under parts nearly the same as above. Length of body alone, 3.50 to 3.75 ; tail alone, about .75 . 
First recorded from Gainesville, Florida, by Dr. C. Hart Merriam, from a specimen taken from the stomach of a barn owl. Specimens have since been taken near Enterprise, by Mr. Brownell.

\section{Fanily TALPID.E. The Moles. \\ SCALOPS AQUATICUS AUSTRALIS Chapman.}

Florida Mole.

No ears visible; feet very large: fur pale seal brown with a silrery gloss; tail very short. Length of body, without tail, about $5 \cdot 50$ : tail. .50 to $\cdot 70$.

Common in many localities. Mr. F. W. True does not consider Scalups parius, Rhoads, as separable from this species (Chap)man, Bull. U. S. Nat. Mus., p. 343, 1894).

Fanily LePorid.e. The Hares and Rabits.

\section{LEPUS PALUSTRIS Bach.}

Marsh Rabbit.

Abundant in Northern Florida. It may easily be distinguished from the Highland rabbits by its small feet, and dark brown color, and dark tail, showing no white.

\section{LEPUS PALUSTRIS PALUDICOLA (Miller and Bangs). Southern Marsh Rabbit.}

This is the marsh rabbit of Middle and Southern Florida. It is similar to the preceding species, but is somewhat smaller and darker in color, and is now generally recognized as a subspecies.

\section{LEPUS SYLVATICUS Bach.}

\section{Gray Rabbit. Highland Rabbit.}

Common in Northern and parts of Middle Florida. It may easily be distinguished from the swamp species by the white on the tail, its longer legs, and larger feet. 


\section{LEPUS SYLVATICUS FLORIDANUS Allen. Southern Gray Rabbit.}

Very similar to the preceding species, but darker and somewhat smaller. It is common throughout Middle and Southern Florida.

\section{Family GEOMIID.E. The Pouched Gophers. GEOMYS TUZA (Ord.).}

Florida Gopher. Salamander.

Very common, usually inhabiting the pine woods, where it lives in holes. The natives call the land turtle (Gopherus polyphemus, Daud.), a " gopher," and this is often confusing, as both animals live in holes and often in the same localities.

\section{FAmily MURIDA. Mice and Rats. NEOTOMA FLORIDANA Say. and Aud. Wood Rat.}

A large, big-eared rat, grayish brown above and whitish beneath ; feet white; length, including tail, I+ to 15.50 ; tail, 6 to 7.25 .

Rather common in some localities, and is supposed to be generally distributed through the State. I have seen many nests of this species and trapped a number of specimens near Cape Canaveral. It prefers the heavily wooded hummocks.

\section{MUS RATTUS Linn.}

\section{Black Rat.}

Above, dark slaty black; under parts dark gray. Size very variable; an average specimen will measure from $I_{3}$ to $I_{5}$ inches in length, including tail.

The Black Rat is not common. Specimens have been taken near Titusville, and Mr. Chapman records it from Enterprise (four specimens taken by Mr. Brownell). This species was introduced into 
America about the year I554, but it has been nearly exterminated by the Norway Rat.

\section{MUS ALEXANDRINUS Geoff. White Bellied Roof Rat.}

A large rat, rather grayer in color than decumamus and whiter on the under parts. The tail is usually longer than the body. This is the common rat usually to be found in houses and stables.

\section{MUS DECUMANUS Pallas. \\ Norway Rat.}

A very large rat, brown above, grayish white beneath ; tail rarcly as long as the body. Claimed to have been introduced into America about I775. The only Florida specimens I have seen of this species were taken in Jacksonville. It is probably confined to the larger towns and cities and not found elsewhere.

\section{SIGMODON HISPIDUS Say. and Ord. Cotton Rat.}

Fur, dark brown, tipped with tawny; under parts grayish white: length, including tail, about 9.50 ; tail, about 3.50 .

Abundant in Northern Florida, being replaced in Middle and Southern Florida by the next.

\section{SIGMODON HISPIDUS LITTORALIS Chapman. South Florida Cotton Rat.}

Similar to the preceding, but decidedly darker; length, including tail, $9 \cdot 5^{\circ}$; tail, $3 \cdot 5$ o.

Common in Middle and South Florida.

\section{ORYZOMYS PALUSTRIS NATATOR Chapman. Florida Marsh Rat.}

Rather large; above brown: dusky white beneath; length, including tail, about I 2 ; tail, 5.50.

Recorded from Gainesville, Enterprise, Micco, Smyrna, and Flamingo. 


\section{MUS rIUSCULUS Linn.}

\section{House Mouse.}

Small; brown above: pale brown beneath: length, including tail, about 5 to 6 ; tail, 2.50 to 3 .

Abundant throughout the State in the vicinity of human habitation.

\section{REITHRODONTOAYS HUMILIS Aud. and Bach.}

\section{Harvest Mouse.}

A small, dark brown mouse; length, including tail, about 5 to 5.75 : tail, 2.25 to 2.60 .

This species is apparently not common. It has been taken at Enterprise and Tarpon Springs.

\section{SITORYS NIVEIVENTRIS (Chapmani). \\ Ground Mouse.}

Above, pale brownish drab: whitish beneath; others, yellowish brown above: whitish beneath; length, including tail, about $5 \cdot 30$; tail, 1.75 to 2 .

Common in many parts of Florida: abundant near the coast.

\section{SITOIYS NIVEIVENTRIS SUBGRISEUS Chapman.}

Old Field Mouse.

Darker than nizeizentris ; brown above, under parts white: length, including tail, about 5.20 ; tail, 1.60 to 1.90 .

According to Mr. Chapman, it inhabits the interior, being replaced in the sandy lands, bordering the ocean, by the preceding species. It frequents old fields.

\section{SITORYYS FLORIDANUS (Chapman). \\ Big=Eared Deer Mouse.}

Ilesperomys floridamus Chapman. Bull. Am. Mus. Nat. Hist., II., ${ }^{1887} 7, \mathrm{p} .87$.

Hesperomy's macropus Merriam. N. A. Fauna, No. 4, I8go, p. 53 . 
Sitomys floridanus Chapman. Bull. Am. Mus. Nat. Hist., V'I., I 894 , p. 336 .

Above, brownish gray, shading into fawn color on the sides; unclerparts white: length, including tail, about $7 \cdot 50$; tail, 3 to 3.50 .

Probably not uncommon, although but few specimens have been taken.

It has been recorded from Enterprise, Gainesville, Citronelle, and at one or two points on the Indian River and at Lake Worth, the latter being Dr. Merriam's type of $S$. macropus.

\section{SITOIIYS ATIERICANUS GOSSYPINUS (Le Conte). \\ Deer Mouse.}

Brown above, whitish beneath; length, including tail, about 7 ; tail, 2.50 to 3.25 .

Abundant frequently in the hummocks.

Mr. Chapman (Bull. Am. Mus. Nat. Hist., VI., I89, p. 336), considers Sitomys megacephalus, Rhoads. (C. F. Rhoads, Proc. Acad. Nat. Sci., Phila., 189t, p. 254) as inseparable from this form, stating that specimens in his series "practically match them both in size and color."

\section{SITOTYS AUREOLUS ( $W a g n$.).}

\section{Golden Mouse.}

General color, golden brown; the underparts are white; length, including tail, 5.50 to 6.25 ; tail, 2.25 to 2.90 .

Specimens have been taken by Mr. J. Robinson, at Gainesville, and by Mr. C. J. Maynard at Dummits Grove, on the Mosquito Lagoon.

\section{ARVICOLA PINETORUM (Le Conte). \\ Le Conte's Pine Mouse.}

Ears nearly concealed; upper parts reddish brown; under parts slaty gray; tail very short; length, including tail, + to +.75 ; tail about .75 . 
Audubon records this species from Florida (Quad. N. A., p. 2 I9, Vol. II.)

\section{NEOFIBER ALLENI. True.}

\section{Allen's Muskrat. Round=Tailed Muskrat.}

Fur long and soft: above, glossy, dark brown; under parts white, showing a slight brownish tinge; length, including tail, I 3 to $\mathrm{I}_{5}$; tail, $4.5 \mathrm{O}$ to $5 \cdot 5 \mathrm{O}$.

This species is abundant on the peninsular east of the Indian River, and is apparently not uncommon in many portions of the State. It has been recorded from Gainesville and Enterprise in the interior. I found it common and captured a dozen specimens near the head of the Banana River.

The common muskrat (Fiber zibethicus) and the beaver (Castor canadensis), may occur in Florida, but have not as yet been taken in the State. (Chapman; Bull. Am. Mus. Nat. Hist., VI., I894, p. $33+$.)

Fanily SCItrid, E. The Squirtels. SCIUROPTERUS VOLUCELLA (Gmel.). Flying Squirrel.

Common in suitable localities. I have several specimens taken near Jacksonville, and it has been taken at Enterprise and Tarpon springs. Length, including tail, 9 to Io ; tail, +.50 to 5 .

\section{SCIURUS CAROLINENSIS Gmel.}

\section{Southern Gray Squirrel. "Cat Squirrel."}

Smaller and more rufous than the Northern gray squirrel : length, including tail, It to $\mathrm{I}_{5}$; tail, 9 to Io.

Common.

\section{SCIURUS NIGER Lim. \\ Southern Fox Squirrel.}

Common in some localities: frequents pine woods. It varies much in color, some specimens being almost entirely black. As a 
rule, the head is black, the back gray, and the under parts tawny; length, including tail, 2 I to $2+$; tail, It to 15.

\section{Finily DIDELPHID.E. The Opossums. \\ DIDELPHIS MARSUPIALIS VIRGINIANA (Kerr). Opossum.}

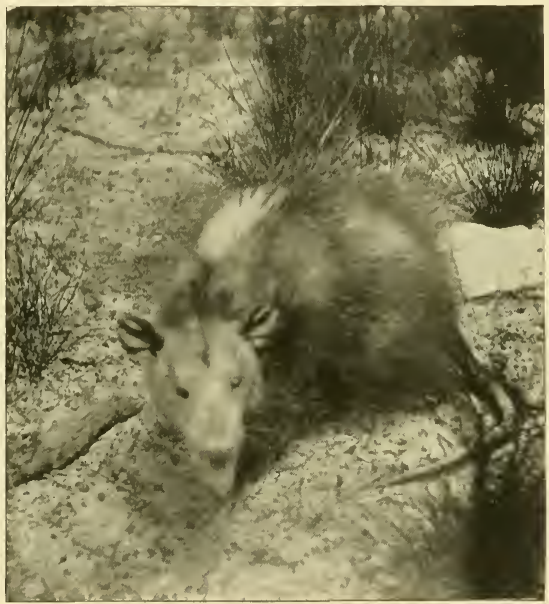

OPOSSUM.

Abundant throughout the State. It is nocturnal in its habits, and, therefore, although so common is rarely seen.

The Porpoise (Phocena phocana L.) and the Dolphin (Tursiops tursio L.) occur on the coast of Florida, and the former occasionally enters the rivers. 


\section{REMARKS ON SOME OF THE FLORIDA SNAKES.}

The snakes of Florida may be divided into two classes, the venomous and the non-venomous. Out of the large number of species known to occur in the State but four may be classed as venomous, and two of these are so small as to be harmless, unless handled or touched with the hand or bare foot; a third, the cottonmouth moccasin, is by no means a common species: and the fourth, the well-known diamond rattlesnake, although exceedingly venomous, is luckily not aggressive, and unless irritated or touched, will rarely attempt to strike.

All venomous snakes have grooved or perforated fangs in the upper jaw ; in some permanently fixed, in others erectile, but always showing the aperture through which the poison is ejected. Nonvenomous species have fixed teeth in the upper jaw in which there is no groove or poison duct.

The venomous snakes which are found in Florida are as follows :--

\section{CROTALUS ADAMANTEUS Bequi' \\ Diamond Rattlesnake.}

Unlike the cotton-mouth moccasin the diamond rattlesnake is not naturally vicious or aggressive, preferring rather to avoid man than to attack him. It is a very dangerous snake, however, as its " bite " nearly always proves fatal. Alcohol and stimulants will often prevent any serious results from the the bite of Western and Northern rattlesnakes ( $C$. horridus), but these remedies have not proved efficacious in cases where persons have been bitten by the Florida species.

In very large snakes the fangs are often three quarters of an inch, or more, in length, and they strike with much force. When 
in the act of striking the snake coils and usually rattles, but it does not always do so.

Its manner of striking is described by S. Weir Mitchell (who has made a most careful study of the species), as follows :-

" The snake throws himself into a spiral, and about one third of his length, carrying the head, rises from the coil, and stands up-

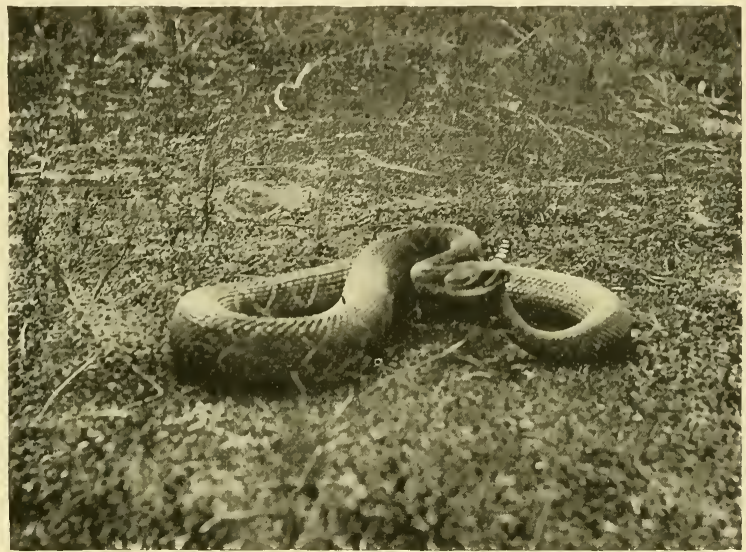

RATTLESNAKE ABOUT TO STRIKE.

right; then his head and neck are thrown far back, his mouth is opened wide, the fangs held firmly erect. The blow is a stab, and is given by throwing the head forward, while the half coils below it are straightened out. As the fangs enter, the temporal muscles close the lower jaw on the part struck and force the sharp fangs deeper in. At this moment the poison duct is opened by the relaxation of the muscle which surrounds it, and the same muscle which shuts the jaw squeezes the poison gland and drives the venom through the duct and hollow fang into the bitten part." 
There is no known antidote for crotaline poison (as the venom of the rattlesnake is called).

Dr. L. Stejneger, of Washington, once suggested to me that a solution of cromic acid or bichloride of gold, injected hypodermically about the wound, might prove efficacious.

As crotaline poison is claimed to act directly on the medulla, it would seem necessary to stimulate the heart's action with the hope of tiding over the paralyzing effects of the poison. * This might,

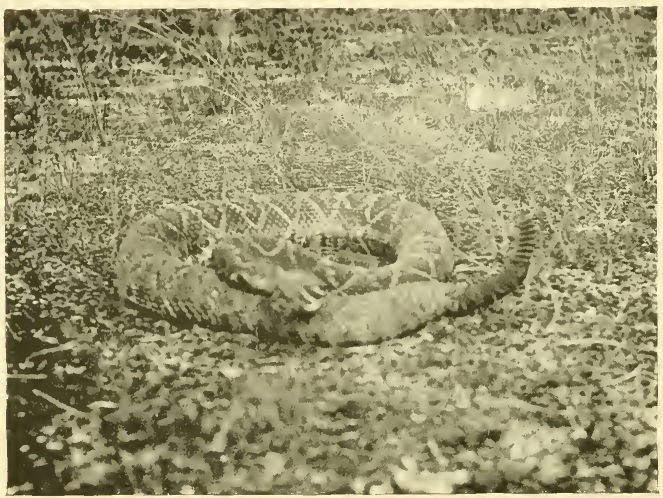

RATTLESNAKE PREPARING TO STRIKE.

perhaps, be accomplished by the use of strychnia, to be given, I should say, in doses of one fiftieth of a grain, repeated every half hour, if there are symptoms of heart failure. Of course, it goes without saying that every possible effort should be made to procure the services of a regular physician.

If a person should be bitten by a rattlesnake the wound should at once be opened to produce a free flow of blood. Ligatures

* Dr. Calmette, a French physician, claims to have attained good results by the use of hypochloride of calcium. $\mathrm{He}$ also clains to have immunized animals by minimal subcutaneous inoculations of attenuated poison and states that the serum of such vaccinated animals possessed strong specific antidotal properties against the poison with which they had been vaccinated. - Annales de l'Inst. Pastenr, Mary, IR94, and April, IS95. 
should be applied above and below the wound to retard, as much as possible, the poison entering the circulation. A strong solution of permanganate of potash * might be injected deeply into the wounds made by the fangs. If that could not be obtained, carbolic acid might answer, the object being to cauterize the wound and prevent, if possible, the absorption of the poison.

A good, stiff dose of brandy or whisky should be given, with a view to counteracting the ill effects on the nervous system produced by fear. Strychnia might then be given internally. and the heart action watched closely. If the patient can be kept alive and conscious for twenty-four hours there is a good chance of recovery.

In India the English govermment not long ago offered a large sum of money as a reward for the discovery of an antidote for cobra poison. A French phrsician succeeded in saving a certain

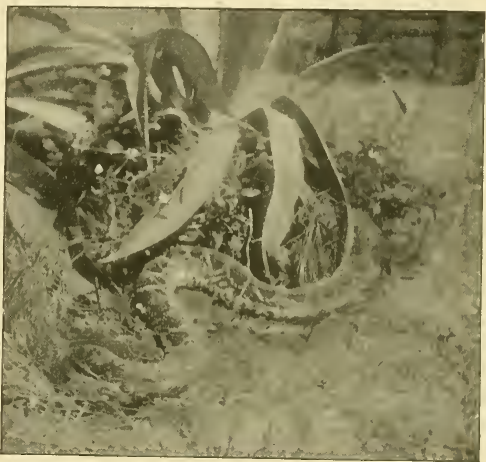
percentage of small mammals which had been bitten by a cobra, by hypodermic injections of pure chloride of lime (chloride of calcium), one part of the chloride to eleven parts of water, and also made use of stimulants. How this treatment would succeed in the case of a rattlesnake is questionable.

Contrary to the general idea, the Indians have no antidote for rattlesnake poison. I have talked with many, and they assure me that if an Indian is bitten by a rattlesnake (which they rarely ever are) " he no get well."

Some very large rattlesnakes have been killed in Florida. I have

\footnotetext{
* Hypochloride of calcium would be indicated in preference to permanganate of potash, if it could be used at once.
} 
seen several over six feet in length, and one which measured seven feet one inch. I have been told that a snake was killed on Anastasia Island which measured nearly nine feet in length.

\section{SISTRURUS MILIARIUS (Linn). \\ Ground Rattlesnake.}

A small snake, rather common, but not often seen, as it keeps well concealed in thick places and under old logs.

It is poisonous but its fangs are small. Ordinary antiseptic treatment of the wound and a rather free use of stimulants usually prevents serious results.

This snake rarely exceeds two and a half to three feet in length. The back is marked with black and red and it has a button on the end of the tail, but no rattles.

Although this little rattlesnake is common in Florida very few of them are seen during the cold months.

\section{AGKISTRODON PISCIVORUS (Linn.). Moccasin, Stump=Tail Moccasin, Cotton=Mouth Moccasin.}

This is a water snake, fully as venomous as the rattlesnake, and much more vicious. They are not common, however, and are rarely seen. I have killed specimens over five feet in length; but it is somewhat unusual for them to attain that size. One killed at the mouth of Moccasin Creek, Banana River, measured five feet two inches. It is a dark-colored snake, the under parts blotched with black and yellow. Young specimens are brighter colored and somewhat resemble in color 1 . contortrix, but the copperhead has not as yet been recorded from Florida.

Like most of the renomous snakes, it has fangs, but no teeth on the upper jaw. Its poison is similar in its action to crotaline, and should be treated in a similar manner. If bitten by a poisonous snake, the wound should receive immediate attention. Ligatures applied (for a time) above and below the bite, cutting the wound to make it bleed freely, and the rather free use of whisky may perhaps be recommended while awaiting the advice of some regular physician. 
The small chance of seeing a poisonous snake, much less being bitten by one, is, perhaps, well illustrated by the fact that such hunters as Quartermain and Davis care nothing for snakes, although they have hunted for many years in Florida, often with bare feet, in the most "snaky localities."

It should be remembered that there are several species of so-called water snakes, which are often seen on the banks of streams and ponds, none of which are poisonous. They are blackish and dark brown generally, with indications of marking on the back.

These harmless varieties are the kinds which are usually pointed out by the natives as the dreaded Water Moccasin.

\section{ELAPS FULVIUS (Linn.).}

\section{Harlequin Snake.}

This pretty little species is conspicuous on account of its transverse bands of yellow, red, and black. It is a small snake, and for many years was considered harmless. It is poisonous, however, and has two very small perforated fangs; but, unlike other renomous snakes, it has both fangs and teeth on the upper jaw.

There are several cases on record where persons have died from the effects of a bite from this snake, and there are also numerous instances where people have been bitten and suffered no ill effects whatever. Still, we know that in some cases the bite of the Harlequin Snake has proved serious; so it is just as well not to treat the little fellow in too familiar a manner.

There are three species in Florida which resemble each other so much that any one but a specialist would probably consider them to be identical. They are very different, however, belonging to different genera : although their general color and appearance is somewhat similar, the colors are differently arranged. The present one, which is the only venomous one of the group, has a roundish head, with the eyes on top, while the others have the eye on the side of the head. One of them has a very pointed head.

The non-venomous ones are as follows. They have teeth on both jaws, but no fangs. 


\section{OSCEOLA ELAPSOIDEA. (Hollrook). CEMOPHORA COCCINEA. (Blumenbach).}

This last is the fellow with the pointed head, and is not uncommon in some parts of Florida.

Dr. Einar Lonneberg says, * ". The bites of harmless snakes may become dangerous from several reasons.

(I) Common blood poisoning that can happen with any wound. (2) Poisoning with the poison from the skin of toads, in cases of bite by species feeding on those animals, as I have often observed that it is possible for some of the secretions from the poison glands in the skin of the toad to remain in the mouth of the snake among the teeth, especially the larger posterior maxillary teeth which inflict the wound. (3) Fear that the snake is poisonous and consequent selfsuggestion."

We now come to the non-poisonous snakes which occur in Florida, which number between twenty-five and thirty species. Many of them are small and rarely seen, and the inhabitants have no local name for them. Others, however, are common and are well known to the natives, who call them by various names in different localities. The following are a few of the better-known varieties : -

\section{NATRIX FASCIATA (Limn.). \\ Water Moccasin.}

This is the common blackish-looking species so often observed along the banks of the rivers and ponds. It is perfectly harmless, but is often pointed out to tourists as the deadly "Cotton-Mouth."

\section{NATRIX TAXISPILOTA (Holbrook).}

A large Water Moccasin, common about the lakes and rivers, usually seen on floating branches of vegetation. It is not venomous.

\section{ABASTOR ERYTHROGRAMMUS (Daudin).}

\section{Thunder Snake.}

A harmless variety, apparently not common in Southern Florida. 


\section{LAMPROPELTIS GETULUS (Lim.).}

\section{King Snake.}

Harmless. It varies in coloration, sometimes showing black and yellow bands. It is claimed that it kills the Rattlesnake, and is sometimes called the Rattlesnake Pilot.

\section{BASCANIUIT CONSTRICTOR (Limn.).}

Black Snake.

The Black Snake is very common throughout Florida. It is not poisonous and has no fangs, but it has a fine set of teeth and is not good tempered. It is black, with the under parts greenish, and the throat dull white.

\section{BASCANIUM FLAGELLUM (Shaw). Coach Whip, Chicken Snake.}

Common, but not so numerous as the preceding species.

\section{CALLOPELTIS GUTTATUS Lim. Chicken Snake.}

Harmless. This and another species, C. quadriziltatus, are both called "Chicken Snakes" by the inhabitants.

\section{SPILOTES CORAIS COUPERII Holbrook. \\ Gopher Snake.}

A rery large, harmless snake. It is claimed that specimens have been killed which measured over nine feet in length. It is black above and plumbeous on the belly, showing yellow on the throat.

\section{HETERODON PLATYRHINUS Latreille.}

Hognose Snake, Spreading Adder, Spitting Adder.

A peculiar little snake, having a turned-up nose. It has the habit of flattening its head and neck and hissing loudly when disturbed, but it is not poisonous.

THAMNOPHIS SIRTALIS (Lim.).

Grass Snake, Garter Snake.

Common in damp ground. A non-poisonous snake, but one that will bite readily if handled. 



\section{KEY}

TO THE

WATER BIRDS OF FLORIDA. 



\section{INTRODUGTION TO BIRD KEY.}

In preparing the present Key, I have striven to make it as simple and non-technical as possible, my object being to enable any one totally unfamiliar with birds to identify with comparative ease any species of the Florida water birds. Let us assume, for example, that a young man has killed a duck and wishes to identify it: he turns over a few pages of the Key until he finds a figure of a bird which resembles his. He then measures his specimen and finds that the length of his bird is 16 inches and the length of the wing is $7 \cdot 4^{O}$ inches. He finds that the ducks are divided into groups, and the group to which his duck would seem to belong was the one comprising birds having a lobe or flap on the little hind toe, the belly white, and which show more or less white or grayish white on the head. In this group he finds there are eleven species, but only four of them which approximate near enough in size to by any possibility be his duck. These are the Ruddy Duck, the two Scaup Ducks, and the Ring-necked Duck. Upon reading the description of these birds he finds that, as his duck is not chestnut and the tail feathers are not stiff and pointed, it cannot be the Ruddy Duck. Of the three remaining species two have the speculum white, the third has it gray. As his duck has the speculum gray it must, therefore, be a female Ring-necked Duck. To be absolutely positive of this he turns over to the latter part of the Key as indicated by "See page" so and so, at the end of each species; he will then be able to read a full description of the bird and so remove any doubt as to the correct identification of the species.

All measurements of birds are given in inches and fractions of an inch. The following diagrams will illustrate how a bird should be measured, and the chart will be useful to the young student of ornithology who may not be familiar with the technical terms used in describing birds. The sexes are indicated by the signs of Mars and Venus: the male, of course, being given that of Mars, $\delta$, and the female $q$. 


\section{MEASUREMENTS.}

LENGTH. - Distance in a straight line from the end of the bill to the tip of the longest tail feather. Occasionally the middle feathers are much elongated, as in Phaethon and Stercorarius.

WING. - Distance from the carpal joint (bend of the wing) to the tip of the longest primary.

T.AIL. - Distance from the tip of the longest tail feather to its base (the point where it enters the body).

BILL. - The distance in a straight line from where the bill (upper mandible) joins the skin of the forehead (A) to the tip (B). (There are a few exceptions to this rule, such as birds with frontal plate, etc. Some curved bills are measured along the curve of the culmen, but in cases of this kind it should always be so stated.)

TARSUS. - Distance in front of the leg from what appears to be the knee joint (end of tibia) to the root of the middle toe.

All measurements are given in inches and fractions of an inch.

Birds vary so much in size that the length of any one specimen cannot be accepted as a standard for others of the same species. The length measure is, nevertheless, of value to enable us to form an approximate idea of the size of the bird; the length of the wing is much less variable and is an important aid to the identification of certain species. 


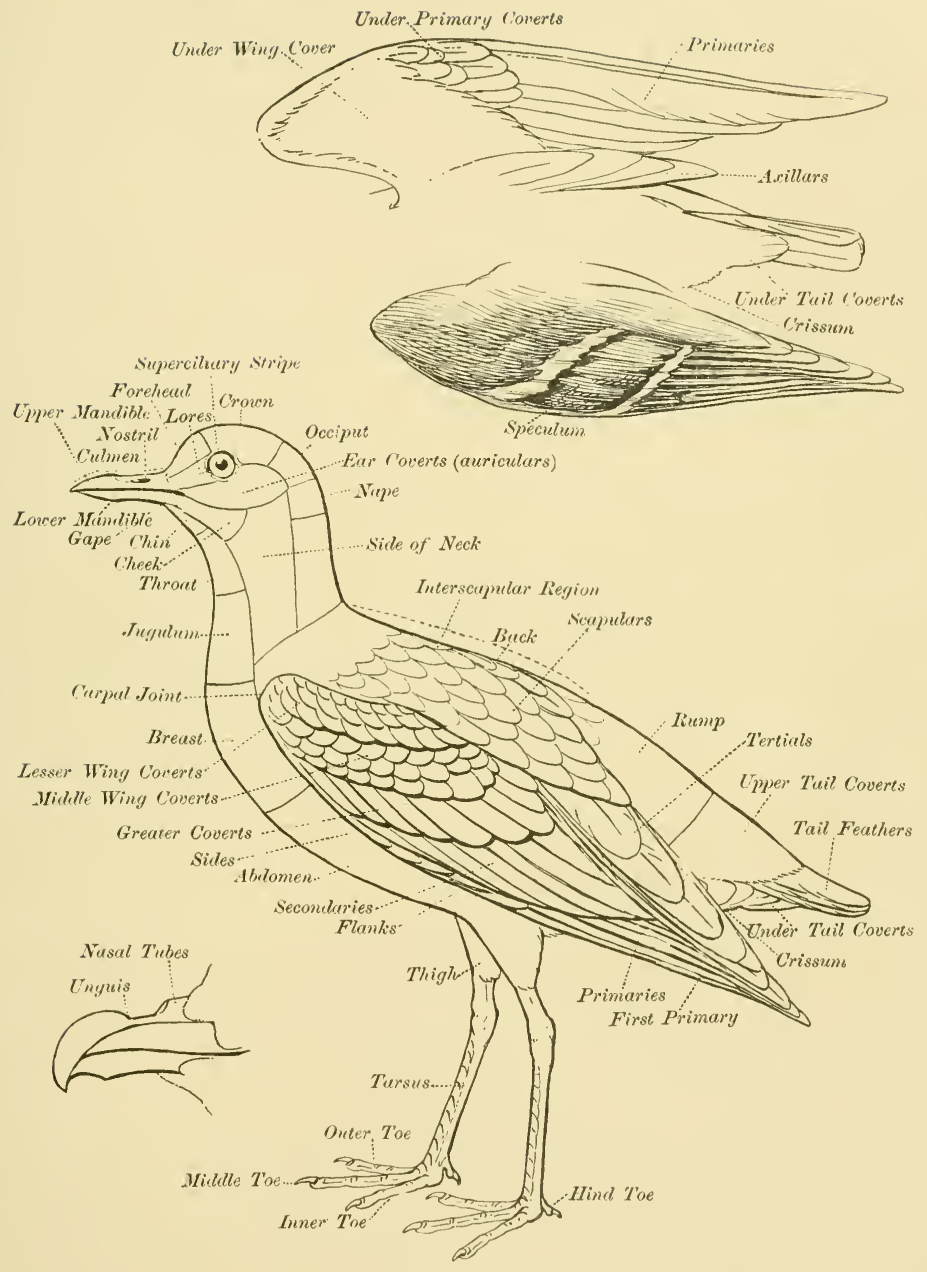




\section{GI,OSSARY.}

Nearly all the terms used in describing a bird may be more easily and clearly understood by examining the accompanying figure than from a written description; a few, however, may, perhaps, require a word of explanation.

MANDIBLES. - Some authors use the word maxilla for the upper half of the bill, and mandible for the lower. I prefer, however, to describe the two halves of the bill as upper and lower mandible.

('ULMEN. - The ridge of the upper mandible.

GONYS. - Lower outline (middle) of under mandible.

UNGUIS. - The nail on the end of the upper mandible; very pronounced in several families of water birds,-- Ducks, Pelicans, and Petrels.

AXILLARS or AXILLARY PLUMES. - Several elongated feathers at the junction of the wing and body (Lat. axilla, the arm-pit).

SPECULUM. - A wing band or patch (usually of a different color from the rest of the wing) formed by the terminal portion of the secondaries; very noticeable in the Ducks.

TARSLS. - Extends from the root of the toes to the end of the tibir (what appears to be the bend of the leg or knee; but which is, in reality, the heel joint).

SUPERCILIIRI STRIPE. - Stripe over the eye. 


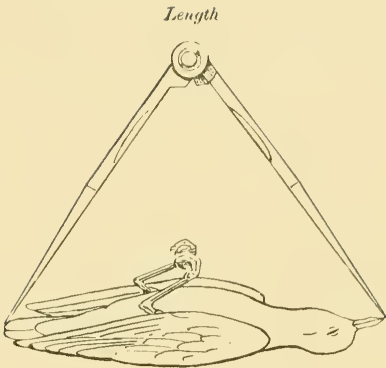

Win!

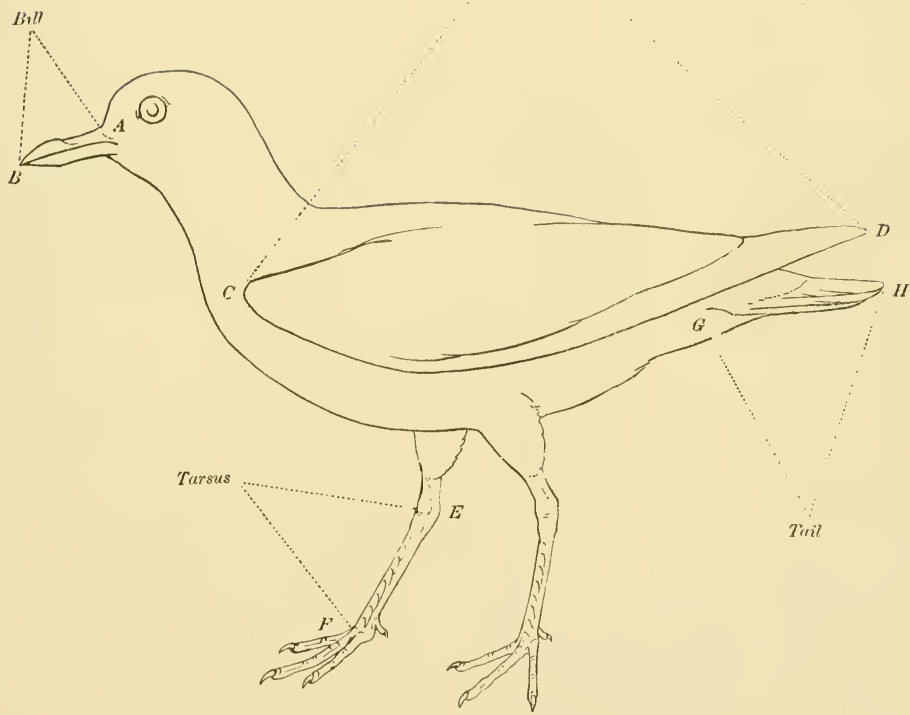





\section{IS F, Y}

I(1) TII

\section{WATER BIRDS OF FLORIDA.}

Fanney PODICIPID.E. Grebes.

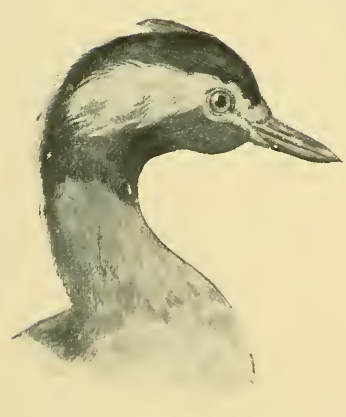

Colymbus auritus.

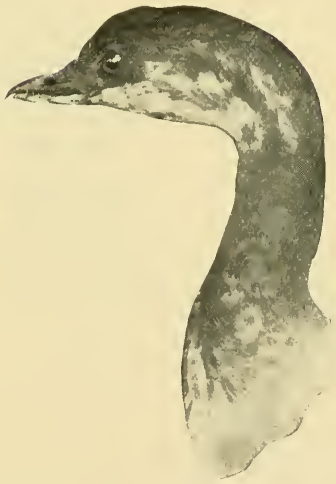

Podilymbus podiceps.

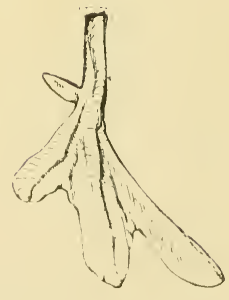

Podilymbus podiceps.
Length, r3.40; Wing, 5.40: Tarsus, 1.70; 13ill, .go.

Length, 13.50: Wing, .5; Tarsus, 1.4.5; 13ill, .go.
Colymbus auritus. Horned Grebe. Sce page $\mathrm{I}_{5}$

Podilymbus podiceps.

Pied-billed Grebe. See page 1 s 


\section{FANIILY URINATORID.E. LoONS-DIVERS.}

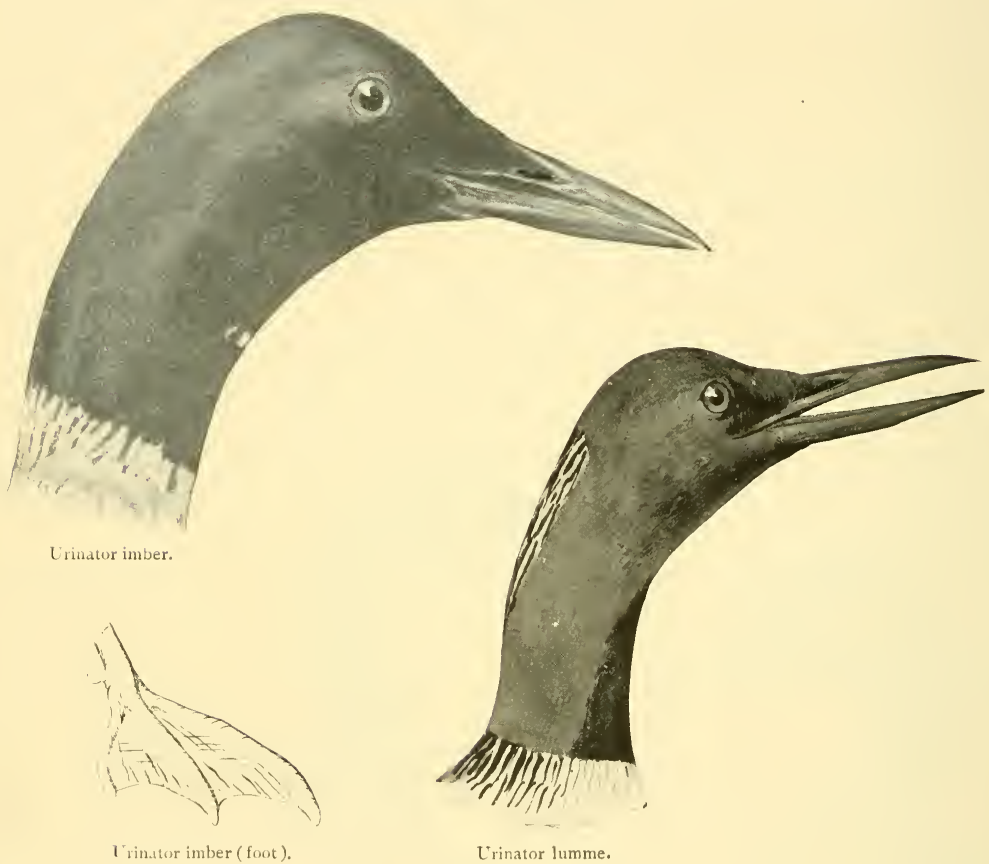

Length, :31; Wing, 1 f: Tarsils. 3.35; Bill. 2.75 .

Urinator imber.

Loon - Great Northern Diver.

See page $18_{7}$

Length, 24; Wing, 10.7.5; Tarsus, 2.75; Isill, 2. $\quad$ Urinator lumme.

Red-throated Loon.

Red=throated Diver. 


\section{FAMILY STERCORARIID.E. JAEGERS.}

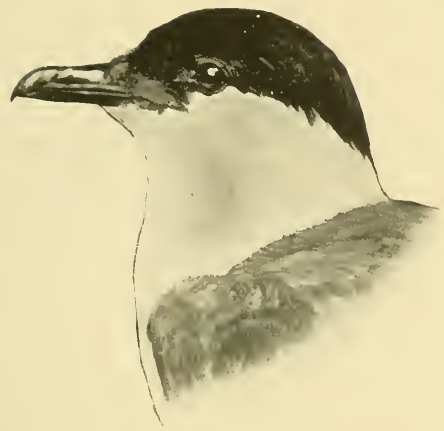

Stercorarius parasiticus (adult).

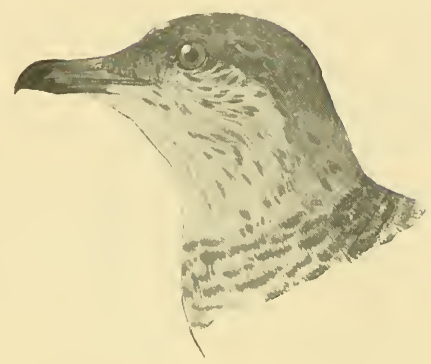

Stercorarius parasiticus ( immature).

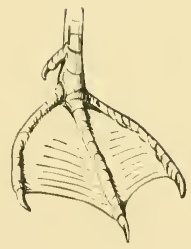

Stercorarius parasiticus (foot).

Central tail feathers elongated in the two following species:

Length, I7; WVing, 13: Tail (adult), about $\mathbf{8 . 4 0 ; ~ T a i l ~}$ (immature), about 6: 1Bill, 1.20.

Length, 20.50; Wing, 1 2.25: Tail (adult), aloout 12.50; immature, alout 6 : bill, 1.10.
Stercorarius parasiticus.

Parasitic Jaeger. See page 1 So

Stercorarius longicaudus.

Long=tailed Jaeger. See page igo 


\section{Finily LARID. E. Gulds and Terns. \\ Supfamily LARIN.E. Gulls.}

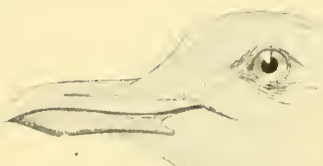

Larus argentatus smithsonianus.

Length, «?): Wing, is: Tail, s: Bill, 2.t0.

Length, 24; Wing, 17.50 Tail, 7.50: Bill, .2.16.

Length, 18.40: Wing, 14: Tail, 6: Bill, about 1.65. In summer, bill yellowish banded with black; in winter, tipped with dark brown.

Length, 1(;..n(): Wing, 12.50: Tail. 5 : IBill, about 1.75. Adult - head and throat plumbeous in summer, whitish in winter; bill reddish.

Length, 13..5(); Wing, 10.40; Tail, 4.15; Bill, 1.30. Adult in summer,- bill black; head and neck plumbeous : feet orange red; in winter, bill black; head and neck white; feet flesh color.

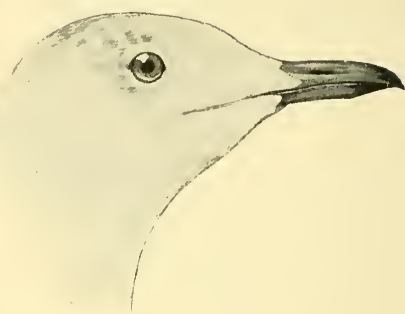

Larus atricilla.

\section{Larus marinus. \\ Gireat Black=backed Gull.}

See page 191

Larus argentatus smithsoni= anus.

American Herring Gull.

See page 192

Larus delawarensis.

Ring=billed Gull. See page 192

\section{Larus atricilla.}

Laughing Gull. See page 193

\section{Larus philadelphia.}

Bonaparte's Gull. See page 193 
SubFamig STERNIN.E. TERNs.

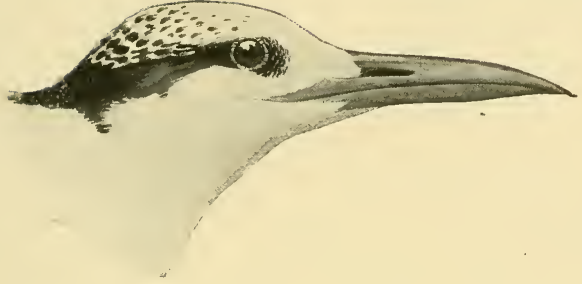

Slerna maxima

Length, 21; Wing, 16; Tail, 6.10: Tarsus, 1.So ; Bill, 3. Bill derp red; primaries dark slate color on inner webs.

Length, 19); Wing, 14: Tail, 7.10; Bill, 2.40. Bill orange or yellow ; back pearl gray ; under parts white.

Length, 17 : Wring, 11.50: Tail, 7.20: Bill, 1.70. Bill black; back and upper parts brownish black: under parts white.

Length, 1.7.50; Wing, 10.50; Tail, 5.60; Bill, 2.10. Bill black tipped with yellow ; back pearl gray: under parts white.

Length, 1.J: Wing, 10.30: Tail, 5.50: Bill, r.45; Tarsus, 70 to .So. Adult in summer-Bill red tipped with black; feet red; under parts ashy. Aduit in winter - under parts white : bill brownish black: Outer web of outer tail feather darker than inner web at all seasons.

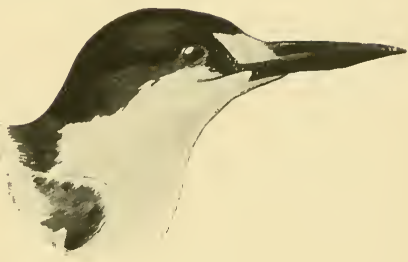

Sterna fuliginosa.

Sterna tschegrava. Caspian Tern.

See page 194

Sterna maxima.

Royal Tern.

See page 195

Sterna fuliginosa.

Sooty Tern.

See page 19 s

Sterna sandvicensis acuflavida. Cabot's Tern.

See page 195

Sterna hirundo.

Common Tern. Sce page 196 


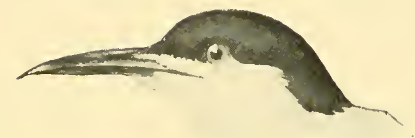

Sterna dougalli.

Length, 15; Wing, 10.25; Tail, 6.60: Bill. 1.50: Tarsus, .9o. Adult in summer-bill dull orange red tipped with black; feet orange red: under parts white. Adult in winter - bill dark brown; feet brown; a dusky black patch on sides of the head inclosing eye; inner web of outer tail feather darker than outer web in all plumages.

Sterna forsteri.

Forster's Tern. See page ign,

Length, 5 : Wing, 7.75 : Tail. 7.50 : Bill, 1.55: Tarsus. . 5 . Bill black, showing tinge of red at the base: tail white: whole of outer tail feather white; under parts white tinged with rose color; feet red.

Sterna dougalli.

Roseate Tern.

See page 197

Length, 1.5: Wing, 10.30: Tail. 6: Bill, 1.60. Entire plumage olive brown; top of head whitish. Immature birds have the top of the head brownish.

Anous stolidus. Noddy Tern.

See page 199

Length, 14..5(); Wing, 10; Tail, 6: Bill, r.6o. (rown black; forehead and line extending over the eye white; mantle gray; under parts white; bill and feet black.

Sterna anathetus.

Bridled Tern.

See page 195 
Length, 1+; Wing, 12: Tail, 5.50: 13ill. 1.40: Tarsus, г.3०. Forehead not white; crown, including forehead, black; upper parts pearl gray : uncler parts white: bill comparatively short and thick; bill and feet black.

Length, 9..51): Wing, S.30: Tail, 3.60: Bill, т.ro: Tarsus. .7०. Adult in summer - under parts black. Adult in winter - under parts white; bill black; feet dusky brown.

\section{Hydrochelidon nigra surina= mensis. \\ Black Tern. See page i99}

Length, !).2.5; Wing, 7: Tail, 3.50; Bill, r.20; Tarsus. 65. Under parts white; bill and feet yellow.

\section{Gelochelidon nilotica. \\ Gull=billed Tern. See page 194}

Sterna antillarum.

Least Tern. See page 197

\section{Finily RHYNCIIOPID E. Skimmers.}

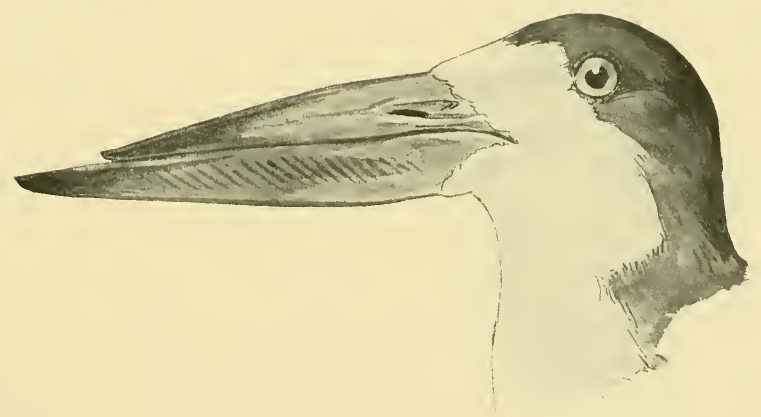

Rhynchops nigra.

Length, 18 to 20; Wing, 15; Tail, 5.50; Bill (culmen), 2.70; (ionys, 4.25. Bill thin, knife=like, lower mandible the longer, hasal half of bill vermilion red, blackish at tip. (ieneral plumage llack, white beneath.

Rhynchops nigra.

Black Skimmer. See page 200 


\section{F.mily DIOnedeid.E. Albatrosses.}

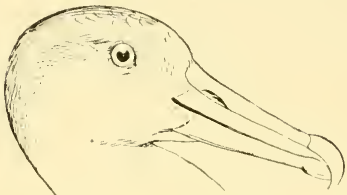

Diomedia exulans. (Very much reduced.)

Length, about 4 feet ; extent of wings (spread), about Io feet to 12 feet. (ieneral color yellowsh white.
Diomedea exulans.

Wandering Albatross.

See page 201

Fanily PROCELLARIIDE. Fulmars, SHEArWaters,

and Petrels.

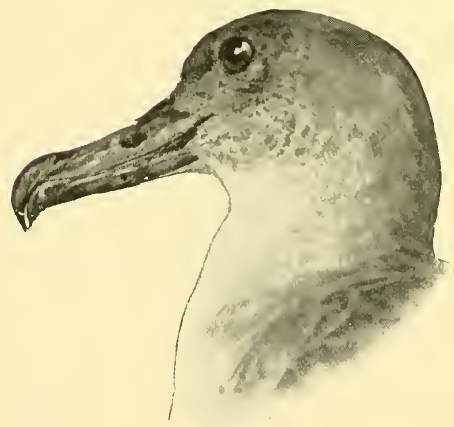

Puffinus major.

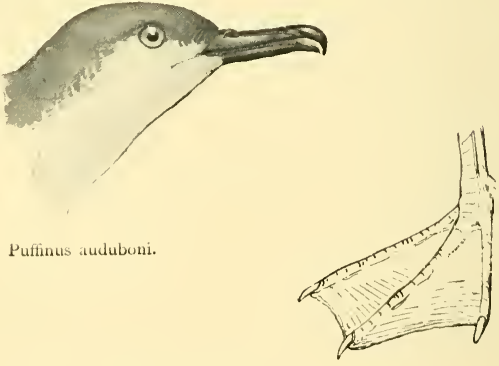

Puffinus major.

Length, 19.25: WVing, 12.50; Tail, 5.75; Bill, 2.40:

Tarsus, 2. Dark brown above, white beneath: crissum dark; under tail coverts gray.

Puffinus major. Greater Shearwater. 
Length, 11.jo; Wing, 8; Bill, 1.20; Tarsus, I.55. Above brown; under parts white; crissum brown and white.

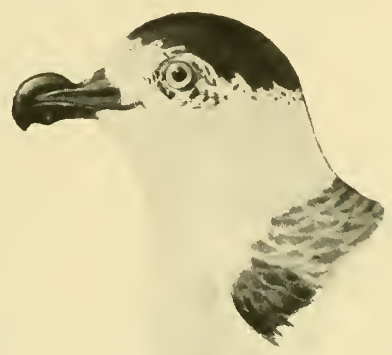

Estrelata hasitata.
Puffinus auduboni.

Audubon's Shearwater.

See page 202

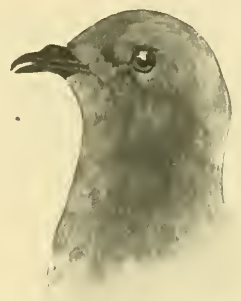

Oceanites oceanicus.
Length, 16..50: Wing, 1:2; Bill, 1.35; Tarsus, 1.40.

Upper and under tail coverts white.

Length, 7; Wing, 5.7.5; Tail, 2.So; Tarsus, 1.30; Bill, .50. General plumage sooty black; white on tail coverts.

Length, s: Wing, (i.2.5: Tail, 3.10 (above dusky); Tarsus, r.50. No white on nape; under parts white.

\section{Astrelata hasitata.}

Black =capped Petrel. See page 202

\section{Oceanites oceanicus.}

Wilson's Petrel. See pagre 203

\section{Cymodroma grallaria.}

White=bellied Petrel.

See page 203

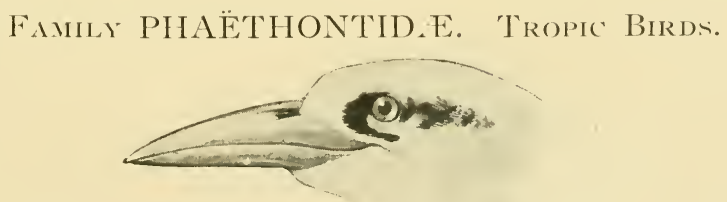

Phaëthon flavirostris.

Length, including tail, $\mathbf{3 1 . 5 0}$ : Wing, 11: Tail, $\mathbf{2 1}$ :

Bill. 2. General color white; bill yellow; central tail feather very long.

Phaethon flavirostris.

Yellow=billed Tropic Bird.

See page 204 


\section{Fanily SULID质. Gannets.}

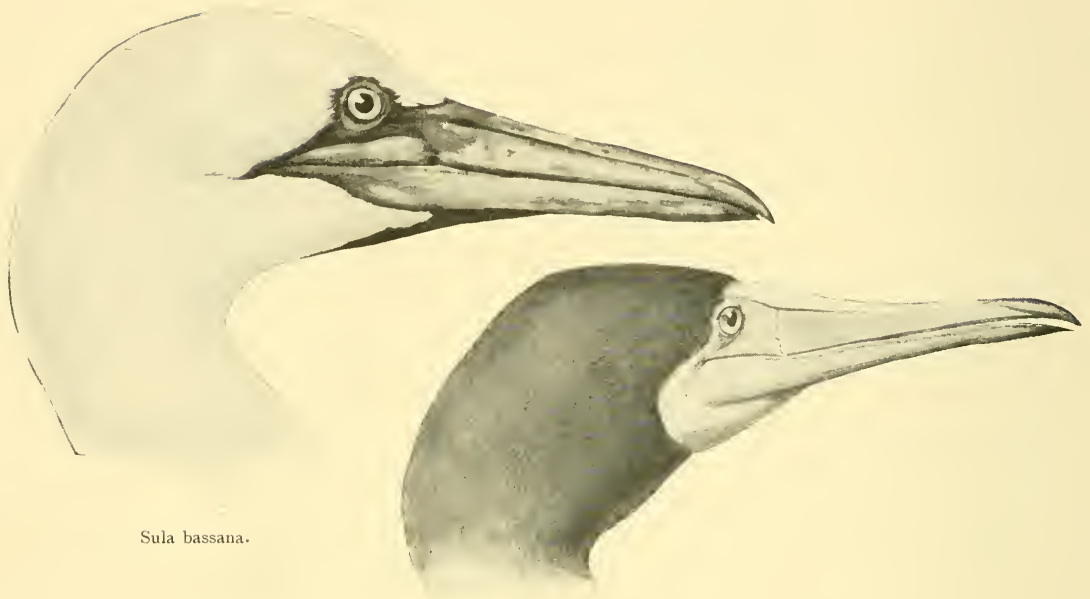

Sula sula.

Length, :36; Wing, 1s.50; Tail, 9; Bill, 4.10. Immature plumage mottled grayish brown and white; head and neck white tinged with buff.

\section{Sula bassana.}

Gannet.

See page 206

Length, $\mathbf{2 7}$; Wing, 15..50; Tail, s : Bill. $f$ : Tarsus, 1.6o. Head and upper parts sooty brown; bill and feet pale yellow; gular sack yellow.

\section{Sula sula.}

Common Booby. See page 205

Length, 27; Wing, 16: Tail, 7.70; Bill, 4; Tarsus,

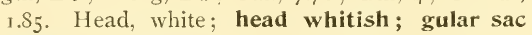
bluish ; feet reddish.

Sula cyanops.

Blue=faced Booby, See page 205

Length, 27; Wing, I5: Tail, S: Tarsus, 2.10; Bill, 3.50. Head white tinged with buff; feet coral red; gular sac dusky.

Sula piscator.

Red=footed Booby. See page 206 


\section{FAMILY ANHINGID L. D.IRTERs.}

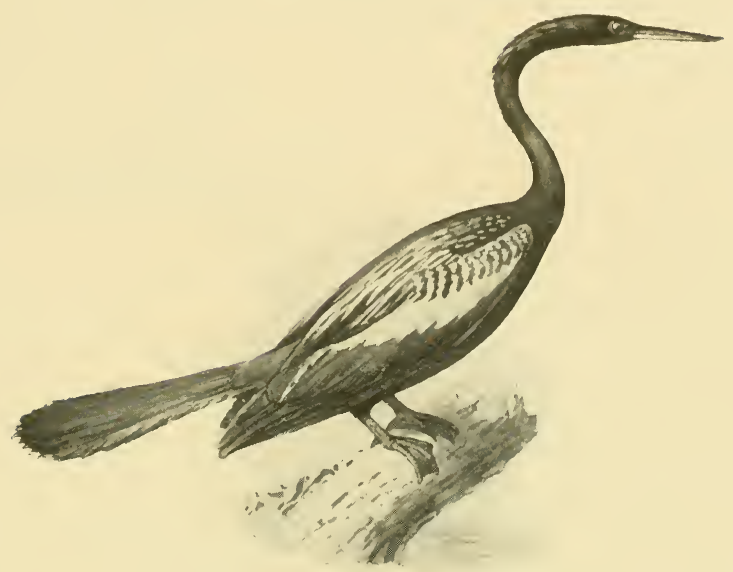

Anhinga anhinga.

Length, 3:3.50: Wing, 1:3..5(): Tail, Io. Long, snake=like neck; head and neck black in male, brown in female.

Anhinga anhinga.

Anhinga, Snake Bird, Water Tur= key.

\section{FAMILY PIIALACROCORACIDA. CORMORANTs.}

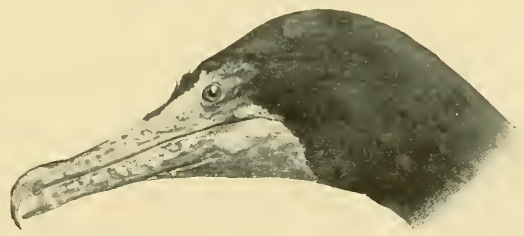

Phalacrocorax dilophus floridanus.

Length, 36; Wing, $\mathbf{1} \mathbf{2}$; Tail, 5.75; Bill, 2.20. Tail consists of 12 feathers.

Phalacrocorax dilophus flori= danus.

Florida Cormorant. See page zos 


\section{FAMIIS PEIACANID,E. PELICANS.}

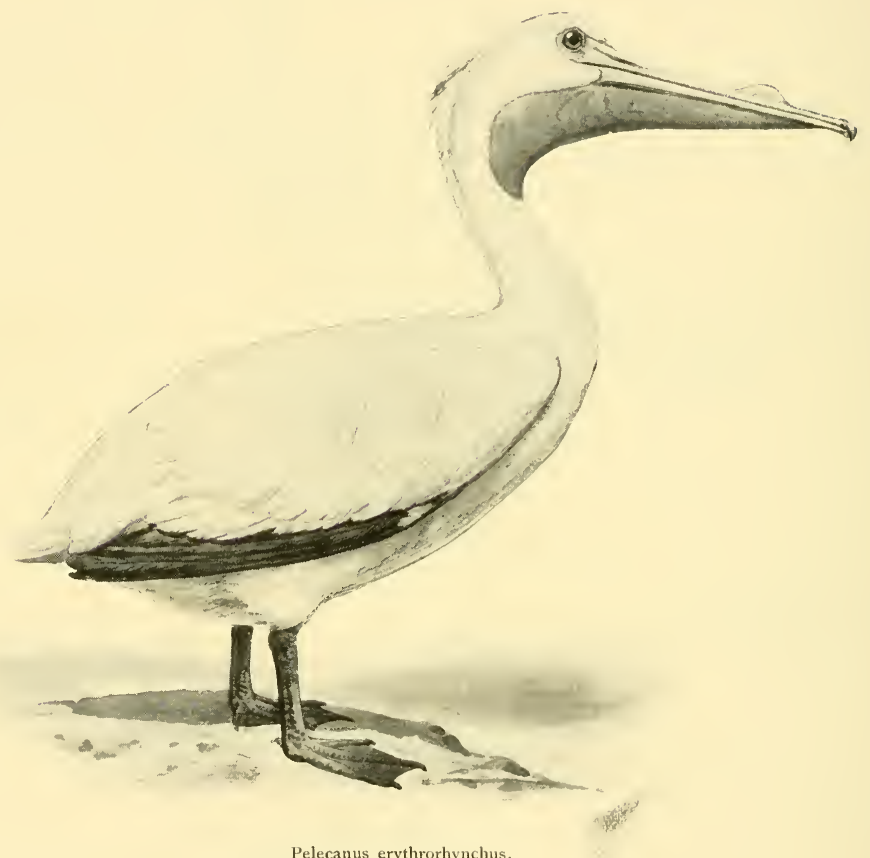

Length, (\$0; Wing, 24.50; Tarsus, 4.45: 13ill. 12. (ieneral plumage white; tail feathers, 24 : pouch yellow.

Pelecanus erythrorhynchus American White Pelican.

See page $20 y$

Eength, 50: Wing, 200: Tarsus, 2.90; 13ill, 11. Plumage not white.

Pelecanus fuscus.

Brown Pelican. See page 210 
Family Fregatide. Man-o'-War Birdes.

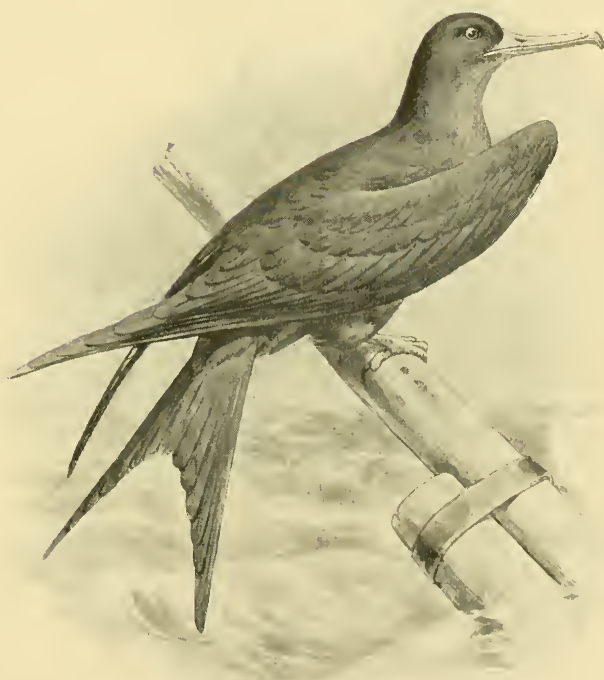

Fregata aquila.

Length, 4:2: Wing, :26; Tail, I6.50; Bill, 5. ¿pper plumage black, tail forked, wings long.
Fregata aquila.

Man=0'=War Bird. See page 211 


\section{FAmily ANATID.E. Du(ks, GeEse, ANI) Sivans.}

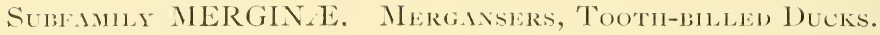

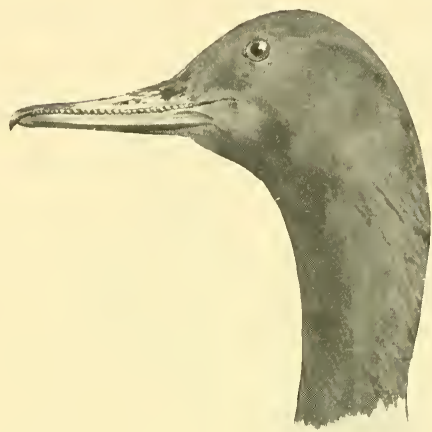

Merganser americana.

(1) Head greenish or blackish; bill narrow, with tooth=like serrations.

Length, 20..50; Wing, 11 : Tarsus, 2 : I3ill. 2.10. U'nder parts creamy white tinged with salmon color.

Length, 2:3; Wing, 9) : Tarsus, 1.90: 13ill, 2.30. Breast brown streaked with black. rlerganser americana. American Tlerganser (male). Sheldrake.

See page 212

Merganser serrator (male). Red $=$ breasted Merganser. Sheldrake. See page 213

Head brownish or grayish; bill narrow, with tooth-like serrations.

Length, 24.50; Wing, 9.75; Tarsus, 1.90; Bill, 2. Distance from nostril to tip of bill less than 1.50 .

Merganser americana (female). American Ilerganser. 


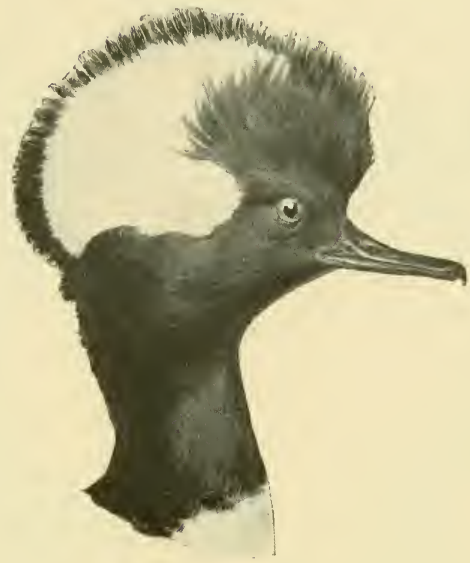

Lophodytes cucullatus.

Length, 21; Wing, 8.80; Tarsus, r.9o; Bill, 2.5c. Distance from nostril to tip of bill more than 1.50 .

Merganser serrator (female). Red=breasted Merganser. See page $2 \mathrm{I}_{3}$

Length, 18.50; Wing, 7.70; Tarsus, r.25; Bill, I.50. Without crest.

Lophodytes cucullatus. Hooded Merganser (immature). See page 214

Length, 18.50; Wing, 7.75; Tarsus, 1.30; Bill, I.50. With small crest.

Lophodytes cucullatus. Hooded Merganser (female). See page 214

(2) Head with black and white crest; bill narrow with tooth-like serrations. Length, 19..50; Wing, 7.75; Tarsus, I.30; Bill, I.50. Lophodytes cucullatus. (adult male). 


\section{Subfanily ANATinfe. River Ducks.}

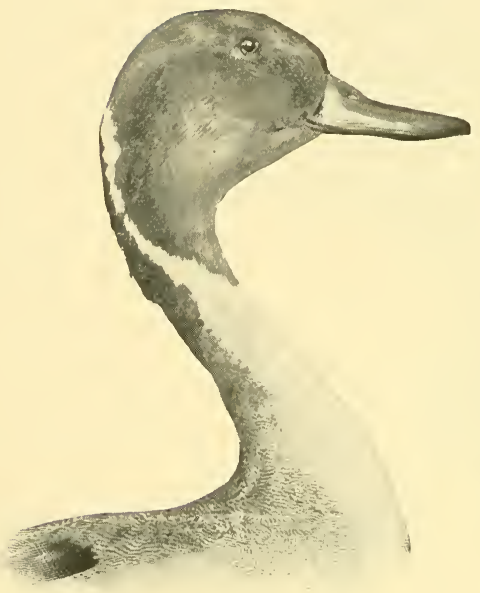

Dafila acuta.

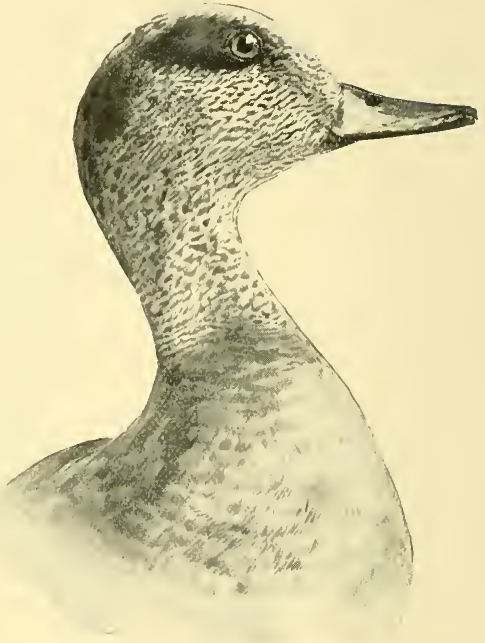

Anas americana.

(I) Hind toe without membranous lobe or flap. Belly white, sometimes faintly tinged with blackish or gray on lower part. Length over 17.50; wing over 8.50.

Length, 28: Wing, 9.50: Tail, 7; Bill, 2. Head brown; speculum green, edged with black and white; middle tail feathers elongated.

Length, 22: Wing. 9.25; Tail, 3.50; Bill, 2. Head brown: speculum brown and white; under wing coverts dark.

Length, 2:3; Wing, 10.50; Bill, 2.20. Head greenish; speculum purplish, bordered with white and black ; feet red.

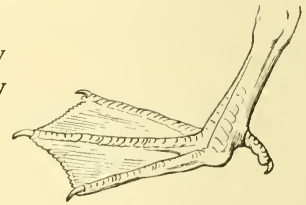

Dafila acuta (male). Pintail.

See page 223

Dafila acuta (female).

Pintail.

See page 224

Anas boschas (male).

Mallard Duck. See page 215 
Length, 19.50; Wing, 10; Bill, ı.6o. Head brownish, streaked; speculum white and brown; feet yellowish; under wing coverts black.

Length, 19; Wing, 10; Bill, 1.55. Head brownish streaked; speculum white and gray; under wing coverts white.

Lingth, 19; Wing, 10.50; Tarsus, 1.60; Bill, 1.40. Head white and green, streaked and speckled with black; speculum black and green; feet bluish.

Length, 18..50: Wing, 9.50; Bill, r.40. Head green and purple, showing white stripe; speculum blue, tipped with black and white; feet yellow.

Length, 18 ; Wing, 9.30; Bill, r.35. Head gray, showing white stripe; feet yellow.
Anas strepera (male).

Gadwall.

See page 21 is

Anas strepera (female). Gadwall. See page 218

Anas americana.

Baldpate Widgeon. See page 219

Aix sponsa (male).

Summer Duck.

Wood Duck.

See page 225

Aix sponsa (female).

Summer Duck.

Wood Duck.

See page 225

(2) Hind toe without membranous lobe or flap. Belly not white.

Length over 17.50 ; wing over 8.50 .

Length, 22; Wing, 11.50; Bill, 2.10; Tarsus, 1.65. Head brownish and buff; belly buff brown, mottled; feet red; speculum purple, bordered with white and black.

Anas boschas (female). Mallard. See page 215

Length, 21 ; Wing, 10.75; Bill, 2.10; Tarsus, 1.75. Head and neck brown streaked; no black spot at base of bill; speculum purple, edged with black; throat streaked.

Length, 20 ; Wing, 10.20; Bill, 2; Tarsus, r.7. Similar to $A$. obscura, but paler: cheeks and throat not streaked; bill yellowish olive; nail of bill and spot at base black: speculum purple, edged with black.

Anas obscura.

Black Duck.

Dusky Duck. Siee page 216 


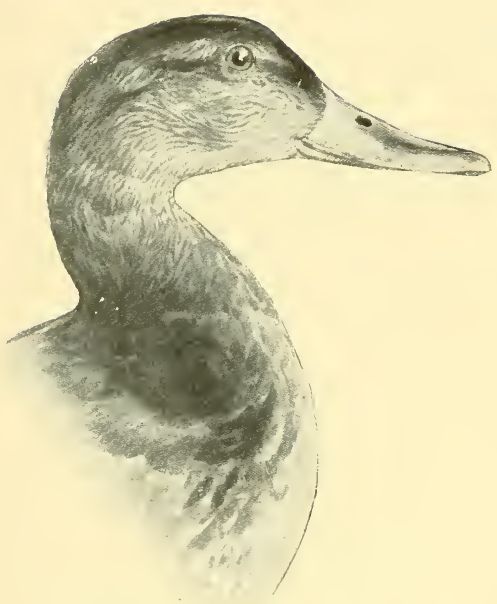

Anas obscura.

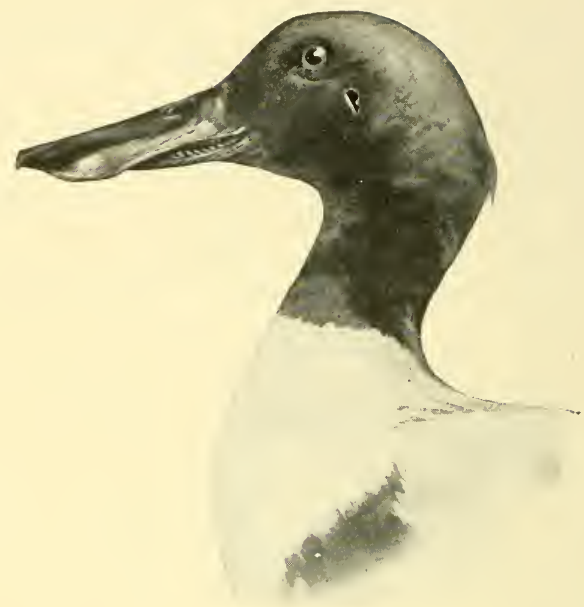

Spatula clypeata (male).
Length, 20; Wing. 950: Bill, 2.70; Tarsus, 1.50. Bill very much broadened; head dark bluish green; feet orange red: speculum green, tipped with white.

I.ength, 19.5(): Wing, 9.50; Bill, 2.60; Tarsus, I.50. Head brown: general plumage mottled and streaked brown and buff: bill very broad: feet orange red; speculum green, tipped with white.

Hind toe without membranous lobe or flap.

\section{Length under 17.50; wing under 8.50.}

Length, 16; IVing, 7.25; Tarsus, I.25: Bill, ı.60. 1 patch on the wing pale blue: head and neck not chestnut; speculum green.
Spatula clypeata (male). Shoveller, Broad=bill.

See page 222

Spatula clypeata (female). Shoveller.

See page 223

\section{Anas discors.}

Blue=winged Teal. See page $22 \mathrm{I}$ 


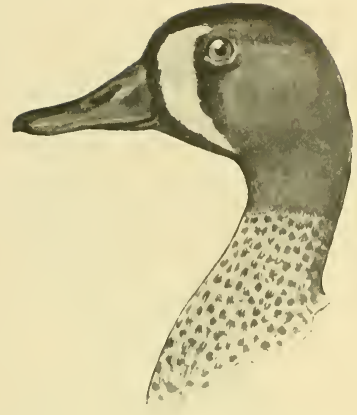

Anas discors (male).

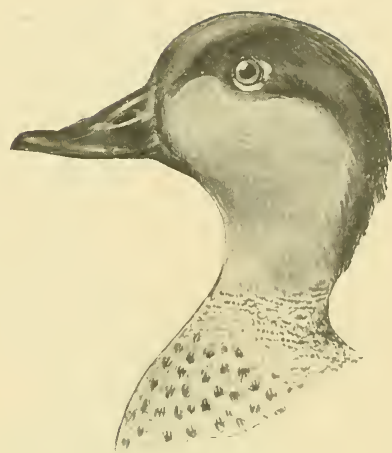

Anas carolinensis (male).

Anas carolinensis.

Green=winged Teal. See page $2=0$

Anas cyanoptera.

Cinnamon Teal. Siee page 221

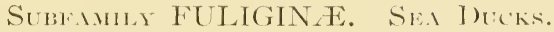

(I) Hind toe with well=defined membranous lobe or flap.

Belly white, sometimes grayish or blackish on lower part; no white on head.

Length, 21..50: Wring, 9: Tarsus, 1.50: Bill. 2.30. Head reddish brown, chin and crown dusky; speculum gray ; upper feathers edged with black. Resembles Redhead Duik. but bill a'ery different. (See figure.)

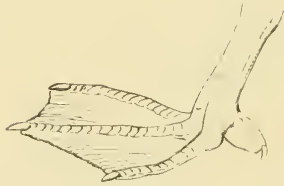

Aythya americana.

Aythya vallisneria.

Canvas-back Duck. See page 227 


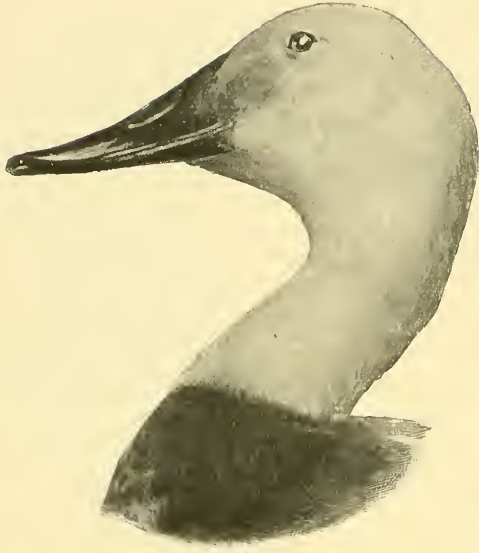

Aythya vallisneria.

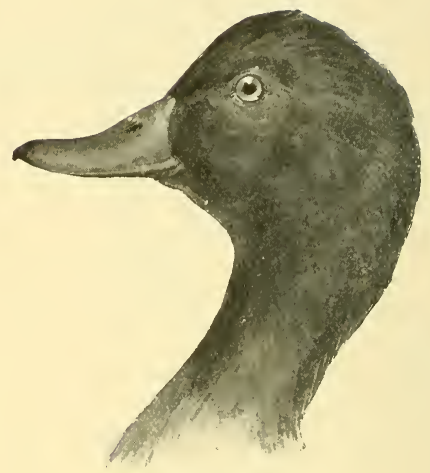

Aythya affinis:
Length, 21; Wing, S.40; Tarsus, 1.60; Bill, 2.20. Head rufous brown; speculum grayish; upper feathers edged with black; the rest narrowly tipped with white. (See figure showing difference in bill from Canvas-back.)

Length, 20.50; Wing, S.30: Tarsus, ז.60; 13ill, 2.20. Head grayish brown: speculum grayish; upper feathers edged with black; the rest narrowly tipped with white. Closely resembles female of Ring-neck Duck (A. iollaris), but is largar.

Length, 19; Wing, 8.50; Tarsus, I.50; Bill, 2. Head black glossed with green; back grayish ; $\mathbf{s p e c u =}$ lum white.

Length, I7; Wing, S.ro; Tarsus, 1.50: Bill, I.So. Similar to the preceding species, from which it differs only in being somewhat smaller; head black with purplish gloss; speculum white.
Aythya americana (male). Redhead Duck. See page 226 ,

Aythya americana (female). Redhead Duck. See page 226

Aythya marila nearctica (male). Greater Scaup Duck.

Bluebill. See page $22 \mathrm{~S}$

Aythya affinis (male).

Lesser Scaup Duck.

Bluebill.

See page 229 
Length, 17; Wing, 7.50: Tarsus, 1.30: Bill, 1.75.

Head black with violet gloss: speculum gray.

Length, 16.50; Wing, S.25; Tarsus, r.40; Bill, r.60.

Head brown; speculum white.
Aythya collaris (male).

Ring=neck Duck. See page 229

Glaucionetta clangula ameri= cana (female).

American Golden Eye.

Whistler.

See page 231

Hind toe with well=defined membranous lobe or flap.

Belly white, sometimes grayish or blackish on lower part.

Head showing more or less white or grayish white.

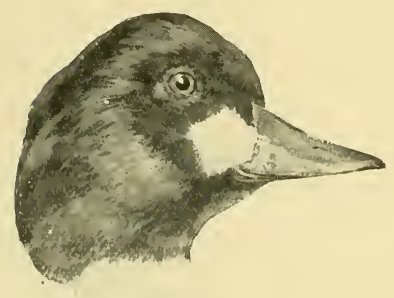

Giaucionetta clangula americana.

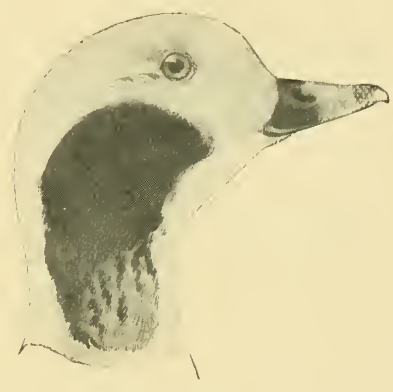

Clangula hyemalis.

Length, including lengthened tail, 21 : Wing, S.50; Bill,

I. Tail pointed; central feathers longest; under tail coverts white.

Clangula hyemalis.

Old Squaw.

See page 232

Length, 17.75; Wing, S.25: Tarsus, 1.30; Bill, 1.60.

Head brownish showing white at base of bill; speculum white.

Length, 16.50; Wing, 7.70: Tarsus, 1.25; Bill, 1.50. Similar to preceding, but somewhat smaller.

Aythya marila nearctica (female). Greater Scaup Duck. Blue $=$ bill. See page 228

Aythya affinis (female). Lesser Scaup Duck. Blue-bill. See page 229 
Length, 19.50: Wing, 9.50: Tarsus, r.75; Bill, 1.50. Head brownish, showing a slight trace of whitish on the sides: under surface of body grayish; whitish on the belly; feathers on top of the bill less than one half inch from nostril; no white on wing.

length, 16.40; Wing, 7.35; Tarsus, 1.20; Bill, 1.75. Head and neck grayish brown; chin and anterior portion of lores whitish: speculum gray. Resembles female of Aythya ameriana but is smalier.

Length, 20.50: Wing, 8.30; Tarsus, r.60; Bill. 2.10. Head and neck grayish brown: becoming whitish on chin: speculum gray: resembles female Aythya collaris. but is larger.

Length, 19.50; Wing, 9.10: Tarsus, 1.60: Bill, 1.90. Head green; white patch at base of bili: speculum white.

Length, 12.75 ; Wing, 6; Tarsus, r.20: Bill. 1 . Mead purple, green, and white; back black : speculum white. A very small duck.

length, 12.50; Wing, 5.75: Tarsus, I.20: Bill, I. White patch on side of the head; back brownish: speculum white. A very small duck.

Length, 15.25; Wing, 6: Bill, I.50: Tarsus, ז.20. General color chestnut brown or grayish brown (according to sex), silvery white beneath: patch of white on side of the head; tail feathers stiff and pointed.
Oidemia perspicillata (female). Surf Scoter.

Skunk=head Coot. See page 235

Aythya collaris (female). Ring=necked Duck. See page 229

Aythya americana (female). Red=head Duck. See page 226

Glaucionetta clangula ameri= cana (male). American Golden Eye. Whistler. See page 231

Charitonetta albeola (male). Buffle=headed Duck.

Buffle-head. Sice page 231

Charitonetta albeola (female). Buffle=headed Duck.

Buffle $=$ head. See page 231

Erismatura rubida. Ruddy Duck. See page 236 
Hind toe with well=defined membranous lobe.

Belly not white.

Length, 2 I ; Wing, I I : Tarsus, 2.05; Bill, r.5o. General plumage black; specuium white; spot under eye white; bill orange at base; feathers on the bill lass than one half inch from nostril.

Length, 20.50; Wing, Ir ; Tarsus, 2; Bill, 1.50. General plumage grayish : speculum white; feathers on the bill less than one half inch from nostril.

Length, IS ; Wing, 9.25; Bill, 1.75; Tarsus, I.S5. Creneral plumage black; no white on the wing; bill orange at base; feathers on the bill more than one half inch from nostril.

Length, 17.50; IVing,9; Bill, г.70; Tarsus, ı.So. General plumage brownish: no white on wing; bill black: feathers on the bill more than one half inch from nostril.

Length, 20; Wing, 9.50; Tarsus, 1.75; Bill, 1.50. (ieneral plumage black; feathers on top of bill extending farther forward than on side of bill; patch of white on hill; orange, black, and white front of head and nape: no white on wings; feathers on the bill less than one half inch from nostril.

Length, 19.50; Wing. 9.50; Tarsus, 1.75: Bill, 1.50. Head brownish, showing a slight trace of whitish on the sides; under surface of body grayish; palest on the belly. Feathers extended on upper part of bill more than on sides: no white on wings; feathers on the bill less than one half inch from nostril.

Oidemia deglandi (adult male). White=winged Scoter. White $=$ winged coot .

See page 234

Oidemia deglandi male in winter and female). White=winged Scoter. White=winged coot .

See page 234

Oidemia americana (adult male) American Scoter.

Butter=bill, Coot. See page 233

Oidemia americana female and immature).

American Scoter.

Butter=bill, Coot. See page 233

Oidemia perspicillata (adult male). Surf Scoter. Skunk=head Coot. See page 2,35

Oidemia perspicillata female). Surf Scoter.

Skunk=head Coot. See page 235 


\section{Subfamily ANSERIN E. Geese.}

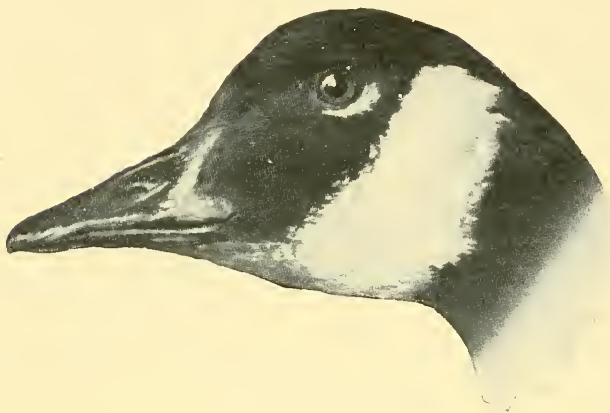

Branta canadensis.

Length, 40; Wing, 19: Bill, 2.50: Tarsus, 3.20. Band of white on sides of the head and throat; bill black; rest of head black.

Branta canadensis.

Canada Goose.

See page 239

Length, 34; Wing, 17.40; Bill, 2.50; Tarsus, 3.10. Entire plumage white; primaries black.

Chen hyperborea nivalis. Greater Snow Goose.

See page 237

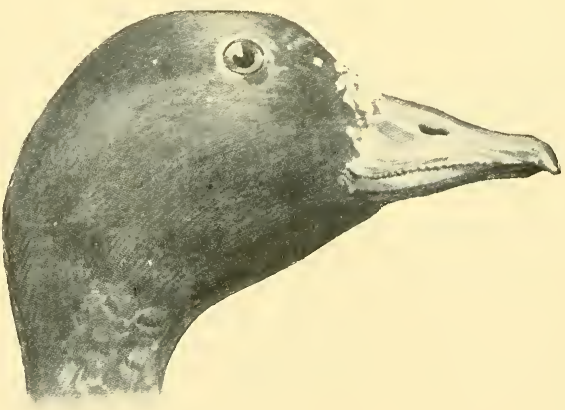


Length, 28; Wing, 16: Hill, 2.20: Tarsus, 3.10. Head white; rest of plumage grayish.

Length, 28; W'ing, 16; Bill, 2; Tarsus, 2.90. Head brownish; bill yellowish; nail black. A line of white at base of bill (adult).

Length, 26: Wing, 13.50: Bill, 1.40: Tarsus, 2.40. Head entirely black; bill black.
Chen carulescens.

Blue Goose. See page 237
Anser albifrons gambeli. American White=fronted Goose. See page $23^{\circ}$

Branta bernicla.

Brant.

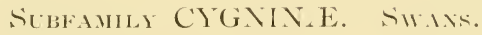

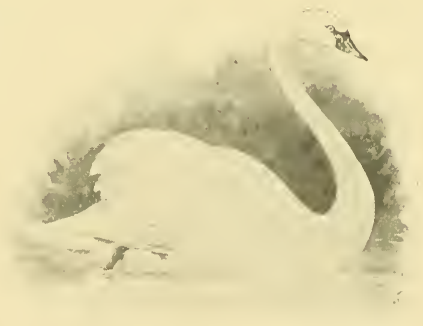

Olor columbianus.

Length, 53; Wing, 21.50; 13ill, 4; Tarsus, 4.20. Distance from front of the eye to nostril longer than from nostril to tip of bill. A spot of yellow on the lores in the adult; young birds gray. En= tire plumage white. 


\section{Fanily PHCENiCOP'TERID.e. Flaningoes.}

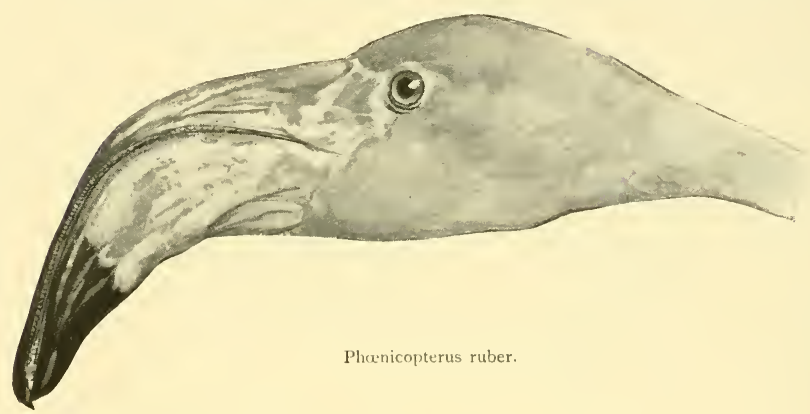

Length, 47: Wing, 16.50: Tarsus, 12: Bill, 5.75.

Plumage vermillion red; bill pale yellow; tipped with black.

Phonicopterus ruber.

Flamingo.

See page 241

\section{FAMIA PIATALEII)E. SPOONBLLS.}

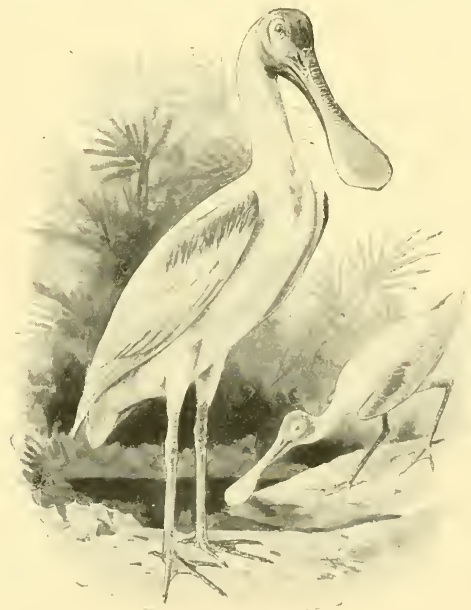

A jaja ajaja.

Length, 31: Wing. 15; Tarsus, 4.10: Bill, 6.30. Bill flat, widened at tip; plumage pink and white.

Ajaja ajaja.

Roseate Spoonbill. See page 242 


\section{Faxily IBIDID E. Ibises.}

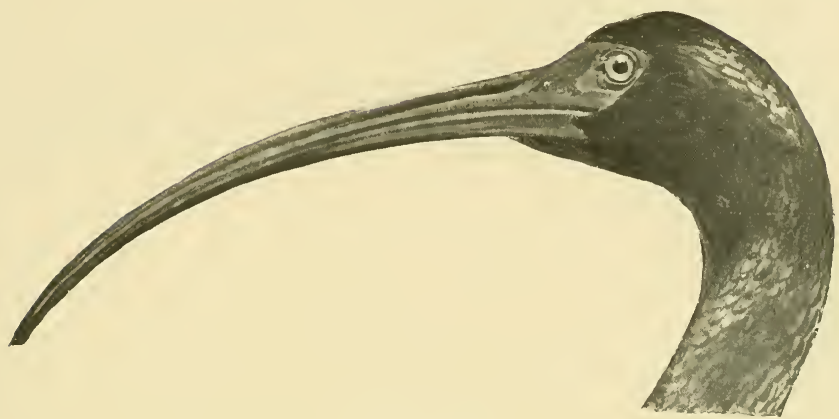

Plegadis autumnalis.

Length, 25; Wing, I1.25; Bill, 5.40. Plumage chestuut brown: nowhite at base of bill.

Length, 25 ; Wing, 11 : Bill, 5.50. Plumage cllestnut brown; a line of white at base of bill.

Length, 26: Wing, Ir.25: Bill, 6.30. I'lumage white; primaries tipped with black.

Length, 26: Wing, I I : Bill, 6.20. Plumage mixed gray and brown; belly white; ruml white.

Length, 27; Wing, 10.50; Bill, 6.20. Plumange brownish mottled; belly white; rump brownish.
Guara alba.

White Ibis (adult). See page $2+3$

Plegadis autumnalis.

Glossy Ibis.

See page 245

Plegadis guarauna.

White=faced Ibis. See page 246

Guara alba.

White Ibis (immature).

See page 243

Guara rubra.

Scarlet lbis (immature).

See page 244 


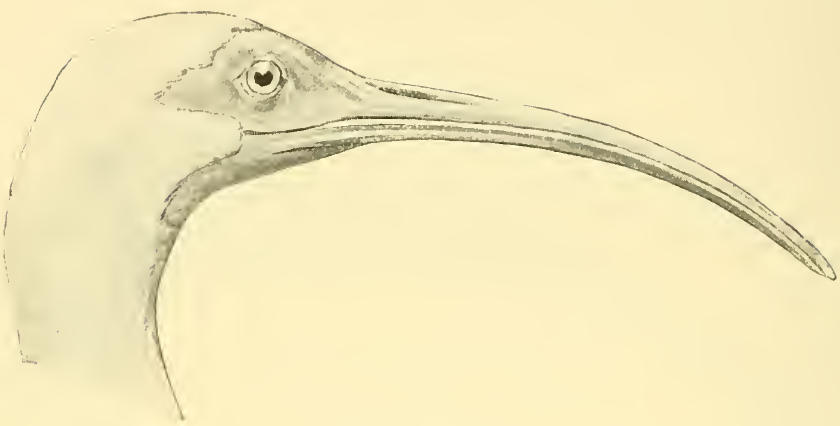

Guara alba (adult).

Length, 28: Wing, Ix; Bill, 6.50. Plumage scarlet; legs and feet red.

Guara rubra.

Scarlet Ibis (adult).

See page 244

\section{FAMIL CICONIID,E. STORKS.}

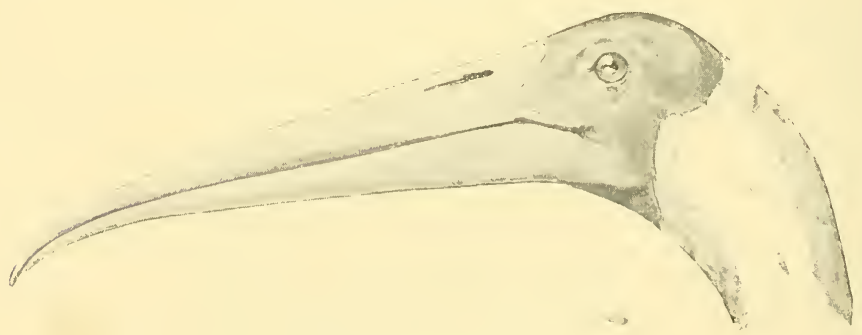

Tantalus luculator.

Length, 41: Wing, I8.50; Tarsus, 8.20; Bill, 9.20.

Plumage white; head and neck without feathers in adult.

Tantalus loculator. 
FaMHA ARDEID E. IIERoNS AND BITTERNS.

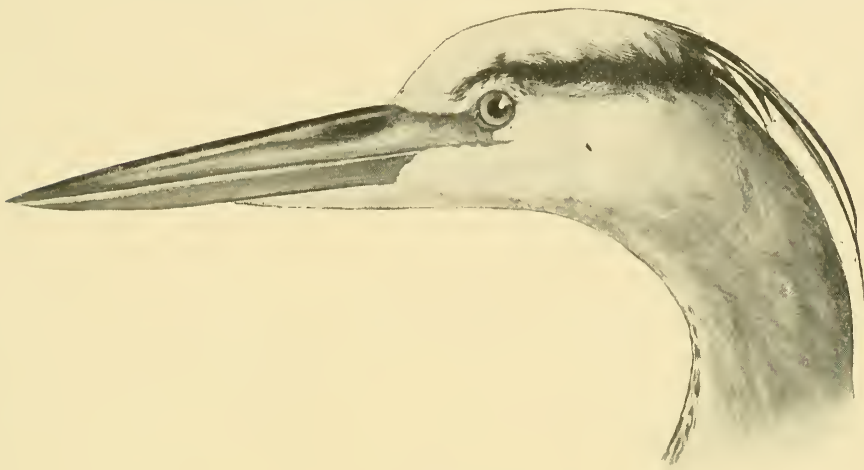

Ardea herodias.

Plumage nearly or entirely white.

Length, 50; Wing, IS.50; Tarsus, S.50; IBill, 6.40. Plumage white; bill yellow; legs greenish yellow.

Ardea occidentalis.

Great White Heron. See page 249

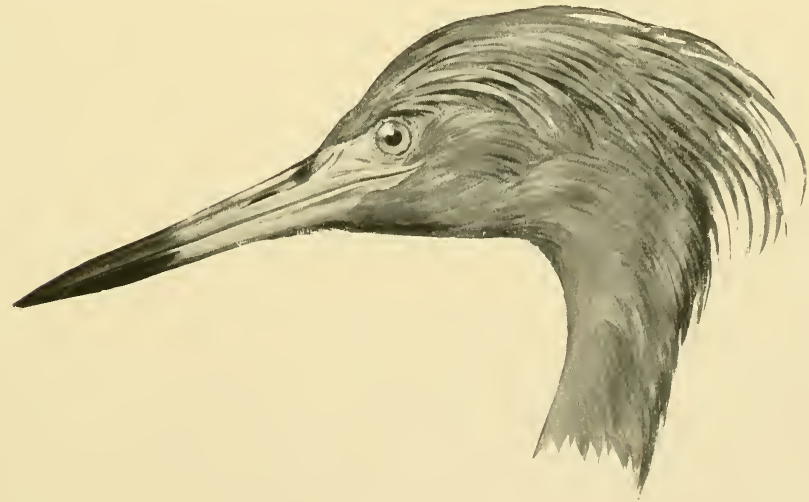


Length, 40: ITing, 15.25; Tarsus, 5.5०; IBill, 4.6c. Plumage white; bill yeliow; legs and feet black.

Length, 28.50; Wing, 1 2.25: Tarsus, 5.25; Bill, 3.50 . Plumage white; legs dark olive; terminal half of bill black: basal half flesh color.

Length, 23.50 ; Wing, 9.50 : Tarsus, 3.75 ; Iill, 3.25 . Plumage entirely white: bill black, showing yellow at lase; legs black; fect yellow.

Length, 22.50; Wing, Io; Tarsus, 3.50; Bill, 3.Io. Plumage white; tips of primaries washed with grayish blue; legs and feet greenisl yellow.

Plumage not white.

Length, 50; Wing, 2o; Tarsus.s; IBill,6.50. General color slaty or grayish variously marked with white, black, and brownish : bill yellowish.

Length, 46: Wing, is.50: Tarsus, 7 : Bill, 5. Similar to Ward's, but somewhat smaller; bill dark.

I.cngth, 29: Wing, 12: Tarsus, 5.40; Iill, 3.So. Head and neck rufous chest nut ; rest of plumage slate color; legs bluish; terminal half of bill black; basal half flesh color.
Ardea egretta.

American Egret. See page 25 I

\section{Ardea rufescens.}

Reddish Egret (white phase).

See page 251

Ardea candidissima.

Snowy Heron.

Little White Egret. See page 252

Ardea coerulea (immature).

Little Blue Heron. Sce page $25^{6}$

Ardea wardi.

Ward's Heron. See page 250

Ardea herodias.

Great Blue Heron. Ste page 250

Ardea rufescens.

Reddish Egret (dark phase of plumage). See page 253 
Length, 27.50: Wing. 10.50: Tarsus, 3.60; Bill. 3.10. Plumage tawny brown, streaked with dark brown.

Length, 26 : Wing, 10: Tarsus, 3.50 ; Bill, 3.So. Elon gated feathers on crown chestnut and white; throat white with brown stripe down the middle.

Length, 24; Wing, 12; Tarsus, 3.60: Bill, 3. Bill thick - black: crown of head white and buff. Immature birds are mottled brown having outer web of primaries slate color, not rufous brown.

Length, 24: Wing, 12; Tarsus, 3.40; Bill, 3. Bill thick-black: crown greenish black. Immature birds are mottled brown, having the outer weh of primaries pale rufous brown.

Length, 22.50: Wing, 10: Tarsus, 3.60: Bill, 3. Head and neck purplish brown: rest of plumage slaty blue: legs and feet black.

Lengtl, 22: Wing, 10: Tarsus, 3.60; Bill, 3. Plumage partly grayish blue, partly white.

Length, 17 : Wing. 7 : Tarsus, .So ; Bill, 2.50. Crown dark greenish; neck chestnut with a line of buffy. white down the middle of throat: legs greenish yellow; belly pale.
Botaurus lentiginosus.

American Bittern. See page 2.47

Ardea tricolor ruficollis.

Louisiana Heron. See page 254

\section{Nycticorax violaceus.}

Yellow $=$ crowned Night Heron.

See page 25)

Nycticorax nycticorax navius.
Night Heron. See page $25 \mathrm{~S}$

\author{
Ardea coerulea. \\ Little Blue Heron (adult). \\ See page $25^{6}$
}

\section{Ardea corulea. \\ Little Blue Heron (immature).}

See page 256

Ardea virescens.

Green Heron.

See page 257 
Leneth. 13.25: Wine. 4.5: Tarsus, r.to: bill, r.Sc. liny small: throat pale yellow huff; molie patis plile.

Ardetta exilis.

l.east Bittern. Si pase 21

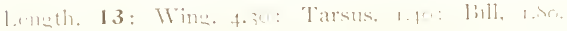

Throat and under parts deep chestnut.

Ardetta neoxena.

Cory's Least Bitteru.

Sien pitge -19

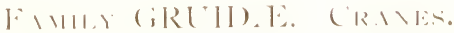

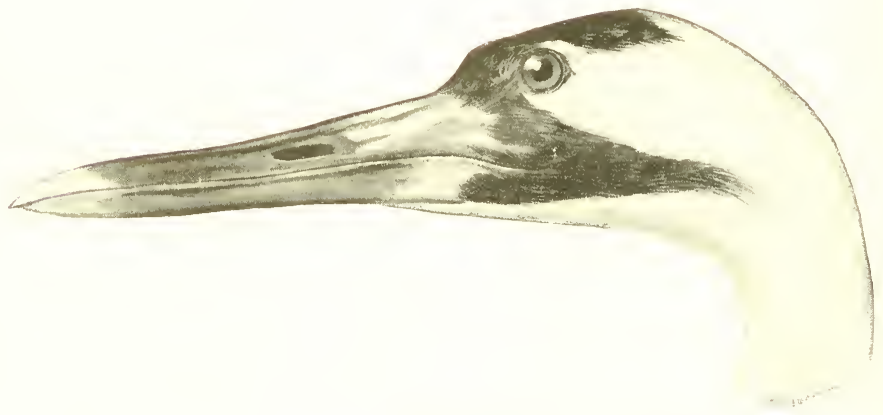

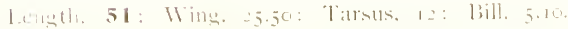
Plumage white; late skin of head red. (loums birds have the head feathered.)

Girus americana.

Whooping Crane. Sec page sur

Length. 45: Wing. 21.50: Tarsus. 10: lisill, 5.50.

Plumage gray or brownish gray; bare skin of head red. (Young lirels have the head feathered.) 


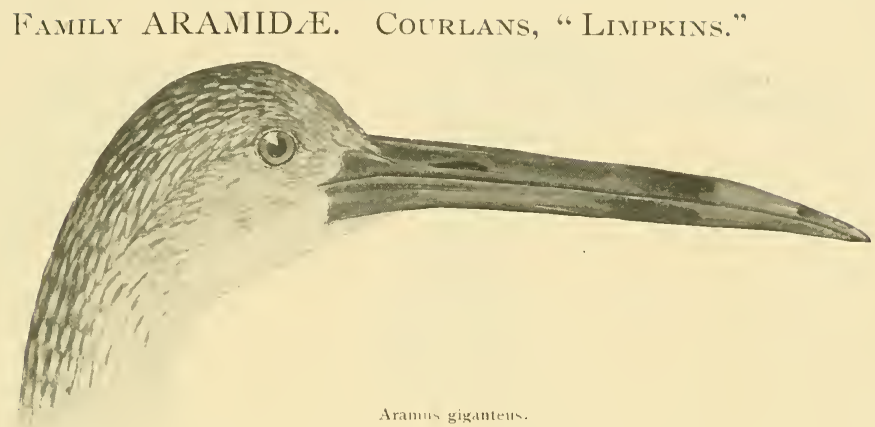

Length, 27.50; Wing, 12.50; Tarsus, 4.30; IBill, 4.10.

Plumage brown, striped with white; under mandible slightly twisted near tip.

Aramus giganteus.

Limpkin, Crying=birà.

See page 263

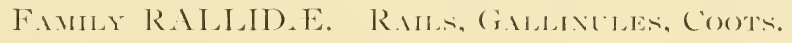
SUBFMHLY R.MLLINE. R.ILs.

Length. 16.50 ; Wing, 6.20: Tarsus, 2.30; lijll, 2.30. Upper parts brownish olive, streaked with lilack : breast cinnamon brown ; wing coverts rufous ; cheek rufous brown.

Length, 15; Wing, 6; Tarsus, 2; 13ill, 2.30. L pper parts grayish olive streaked with black; breast pale buff ; cheeks grayish.
Rallus elegans. King Rail. See page 264

Ralius longirostris crepitans. Clapper Rail. See page 265 


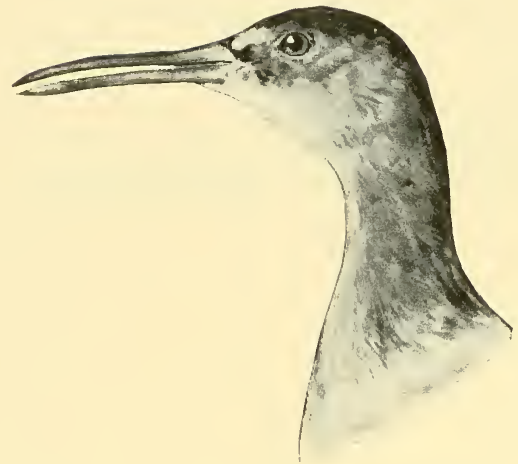

Rallus elegans.

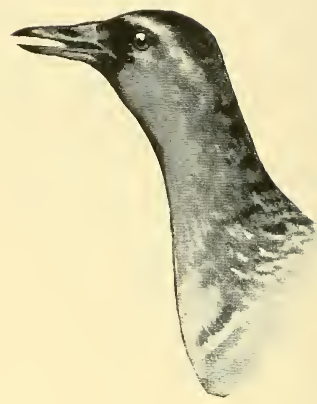

Porzana carolina.
Length, 14.50: Wing, 5.75: Tarsus, 1.90: Bill, 2.10. Upper parts dark olive lrown: wing coverts not rufous brown.

Length. 8.75: Wing. 4.20: Tarsus, 1.30: Bill, 1.50. (pper parts dark: throat white: belly brown.

\section{Rallus longirostris scottii.}

Scott's Rail.

See page 260

\section{Rallus virginianus.}

Virginia Rail.

See page 265

I.ength, 8.40: Wing. 4.20: Tarsus. 1.25: Bill. 75 to 90. ( pper parts dark: throat gray: a stripe on top of head and at base of bill black; lower belly white.

Length, 7.20: Wing, 3.50: Tarsus, i : Bill, 55. Feathers of back banded with narrow white lines and edged with pale brown: upper belly white.

Length, 5.50: Wing, 3: Tarsus, .90: IBill. .60. Head, neck. and upper belly slaty gray; lower belly plumbeous or blackish.

\section{Porzana carolina. Carolina Rail. Sora.} See page 266

Porzana noveboracensis.

Yellow Rail. See page 267

Porzana jamaicensis.

Little Black Rail. See page 267 


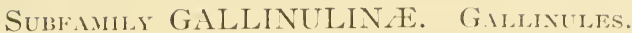

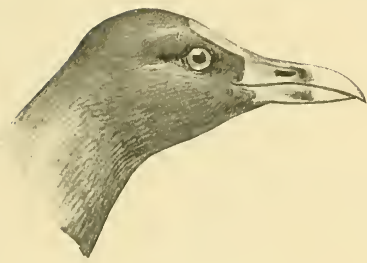

Jonornis martinica.

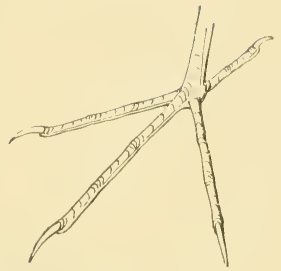

Ionornis martinica.

Length, I I : Wing, 7 ; 13ill, 1.So: Tarsus, 2.fo. Gen= eral color purplish blue; toes without lobate webs; legs and feet yellow.

Ionornis martinica.

Purple Gallinule. Sie pitge $26 \mathrm{~S}$

Length, 12; Wing, 7.10; Bill, 1.So: Tarsus, 2.25.

General color olive brown and gray; frontal

shield and most of bill red: toes without lobate webs; legs and feet greenish, showing scarlet on upper portion of tibia.

Gallinula galeata.

Florida Gallinule. Siec page 268

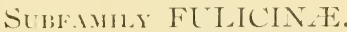

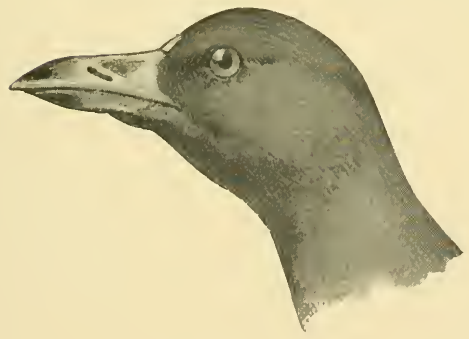

Fulica americana.

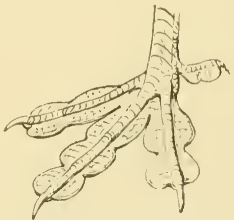

Fulica americana.

Length. 15.50 : Wing. 7.40: Tarsus. 2.20. Toes with lobate webs; legs greenish: basal portion of bill and frontal shield white: general plumage slate color: head blackish.

Fulica americana.

American Coot, Mud=hen.

See pare $2(x)$ 


\section{Fanily PIIALAROPODIDA. Phalaropes.}

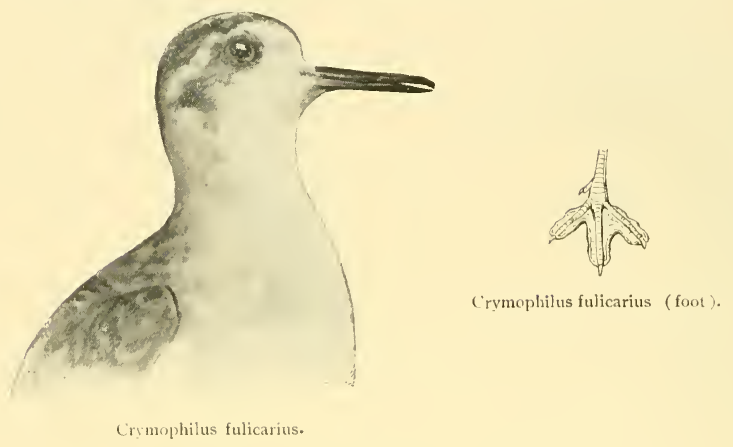

Length, 7.50: Wing, 4.40: Bill, .90: 'Tarsus, .S5.

Upper parts gray; neck marked with rufous; under parts white.

Phalaropus lobatus.

Northern Phalarope. See page 270

Fanmy RECURVIROSTRID.E. Mvocets ANI Stuts.

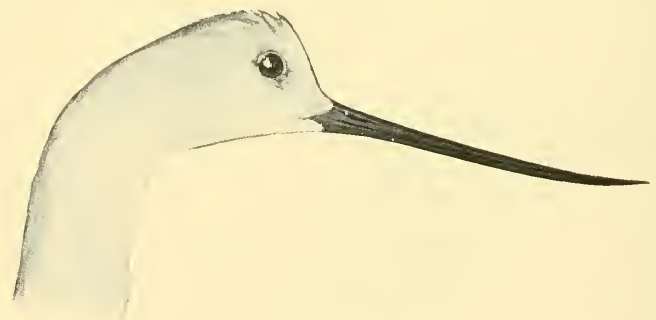

Recurvirostra americana.

Length, 17.50; Wing, S.75: Tarsus, 370 ; Bill, 3.60.

Bill curved upwards - very slender: middle back, rump and belly white; legs bluish; head and neck rufous in summer, gray in winter.

Length, 15: Wing, S.75: Tarsus, 3.90: Bill, 2.60.

Recurvirostra americana.

American Avocet. See page 271

Forehead, bill straight: a spot behind the eyc, and under parts white: rest of head, back, and wings black; legs pink red.

Himantopus mexicanus.

Black-necked Stilt. Siee page $27^{2}$ 
Family Scolopacid.E. Snipes, Sinppipers, Cerlews.

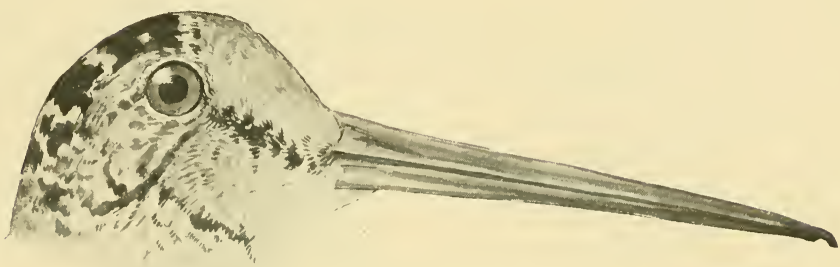

Philohela minor.

Length under 13 ; wing under 7 ; bill over 2 ; toes four in number.

Length, 11: Wing. 5.50; IBill, 2.70; Tarsus, 1.25. Under parts rufous brown: three outer prima= ries attenuated; fourth and fifth primaries longest.

Length, 11; Wing, 5.35: Tail, 2.25; Tarsus, 1.25; Bill 2.60. Throat whitish; belly white: under tail coverts barred with black; no ath hetwe'n toes.

Length, 10.50: Wing, 5.50: Tarsus, 1.35: Bill, z łо. Tail and tail coverts barred with black: a s'ory small web between the inn'r toes.

Length, 10.75: Wing. 5.75: Tarsus, r.50: Till, 2.65. Resembling preceding species, but somewhat larger; bill longer.
Philohela minor. American Woodcock.

See page 273

\section{Gallinago delicata. Wilson's Snipe. English Snipe.}

See page 273

Macrorhamphus griseus.

Dowitcher.

Red=breasted Snipe.

See page 275

Macrorhamphus scolopaceus.

Long=billed Dowitcher. Red=breasted Snipe.

See page 275 


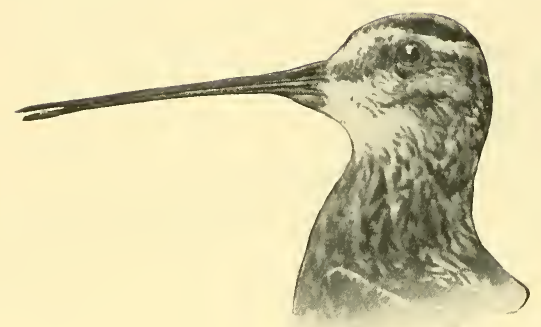

Gallinago delicata.

Length under 1.3; wing under 7 ; bill less than 2 and more than 1 ; toes four in number.

Length, 12; Wing. 6.75: Tarsus, 2: Bill. r.15. Bill greenish, yellowish at base; legs grayish yellow; head, upper parts, and breast mottled brown and tawny; axillars barred white and slate color: belly white.

Length, 10.50; Wing, 6.40: Tarsus, 2.05: Bill. 1.40. Legs yellow: bill black: upper parts grayish brown: breast mottled; belly white.

Length, 10.50; Wing. 6.40: Tail, 2.40: Tarsus, 1.30: Bill, 1.50. Legs and feet black. In summer under parts, except belly, reddish brown : in winter upper parts gray: breast pale gray.

Length, 9: Wing, 5.25; Tarsus, 1.05: Bill, 1.15. Upper parts brown and tawny; throat and belly white; breast pale brown.
Bartramia longicauda.

Bartramian Sandpiper.

Upland Plover. See page 286

Totanus flavipes.

Summer Yellow=legs.

Yellow =legs.

See page $2 s_{3}$

Tringa canutus.

Knot. See page 276

Tringa maculata.

Pectoral Sandpiper.

Grass=bird.

See page 277 


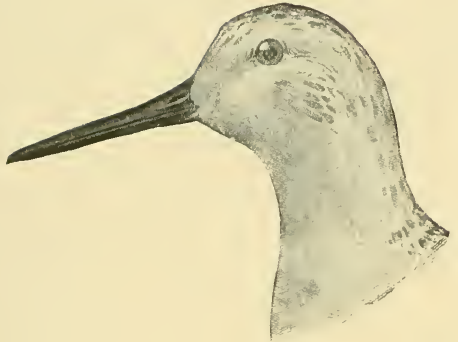

Tringa canutus.

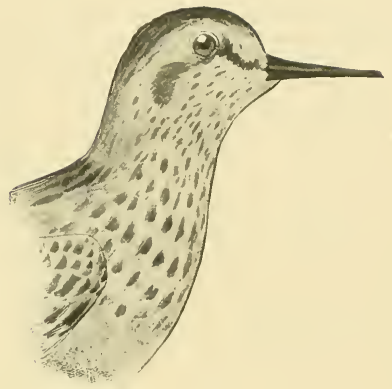

Tringa maculata.
Length, 8.75: Wing, 5.20; Tarsus, I; Bill, 1.30 . Upper parts gray, showing faint purplish reflections.

Length, 8: Wing, 5.20: Tarsus, 1.60: Bill, 1.20. Jack olive green spotted with white: axillars barred.

Length, 8: Wing, 5.20: Tarsus, ı.60: Bill, 1.60. Legs long: upper tail coverts barred with black and white in summer: white in winter.

Length. 7.90: Wing, 4.90: Tarsus, 1.05: Bill, 1.60. Upper leelly black in breeding plumage. In winter breast gray, shafts of the feathers brown.

Length, 5.40: Wing, 3.So: Tarsus, .90; Bill, 1.10. A small web between the toes.

\section{Tringa maritima.}

Purple Sandpiper. See page 277

Totanus solitarius.

Solitary Sandpiper. Sec page $2 S_{4}$

Micropalama himantopus.

Stilt Sandpiper. See page 276

Tringa alpina pacifica.

Red-backed Sandpiper.

American Dunlin. See page 279

Ereunetes occidentalis.

Western Sandpiper. See page 280

\section{Length under 10; wing under 6 ; bill 1 or less; toes four in number.}

Length, 8: Wing, 5.30; Tarsus, I. 10; Bill, .So. Breast buff or grayish buff.
Tryngites subruficollis.

Buff=breasted Sandpiper.

See page 287 
Length, 7.70; Wing, 5.10: Tarsus, 1.05: 13ill. .9o. Middle upper tail coverts white.

Length, 7.50; Wing, 4.40: Tarsus, I: Bill, .90 to 1 . Back olive green, showing bronzy reflections when held in the light.

Length, 5.75 : Wing, 3.So; Tarsus, .9o: Bill. .s5. A small web between the toes.

Length, 5.75; Wing, 4.05; Tarsus, .yo: Bill, .7o. No web between the toes.

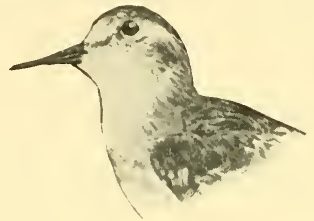

Tringa minutilla.
Tringa fuscicollis.

White=rumped Sandpiper.

See page $27 \$$

Actitis macularia.

Spotted Sandpiper. Siee page $2 S_{7}$

Ereunetes pusillus.

Semipalmated Sandpiper.

See page 279

Tringa minutilla.

Least Sandpiper. See page $27 \mathrm{~S}$

Length under 10 ; wing under 6 ; toes three in number.

Length. 8.15: Wing. 5.05: Tarsus. .95: 13ill, 1.

Length over 1.3; wing over 7 ; bill over 2.75 ; toes four in number.

Length, 24; Wing, ro; Tail. 4.ro; Tarsus, 2.30; Bill from + to $S$. Bill very long and curved dow $\mathbf{n}=$ ward : general plumage brownish rufous : axillars barred.

Length, 18; Wing, 9: Tail, 3.60: Tarsus, 3: Bill, 4.60. Upper parts brownish : under parts rufous : bill curved slightly upward; axillars brownish.

Length, 17.20; Wing, 9.40; Tarsus, 2.10; 13ill. 3.70. Bill curved downward; plumage mottled brown above, middle of head with dull buffy white stripe ; axillars barred.
Calidris arenaria.

Sanderling. Shee paye zso
Numenius longirostris.

Long=billed Curlew. See page $2 S S$

Limosa fedoa.

Marbled Godwit. See page 2 is

Numenius hudsonicus.

Hudsonian Curlew.

Jack Curlew.

See page $2 S_{9}$ 


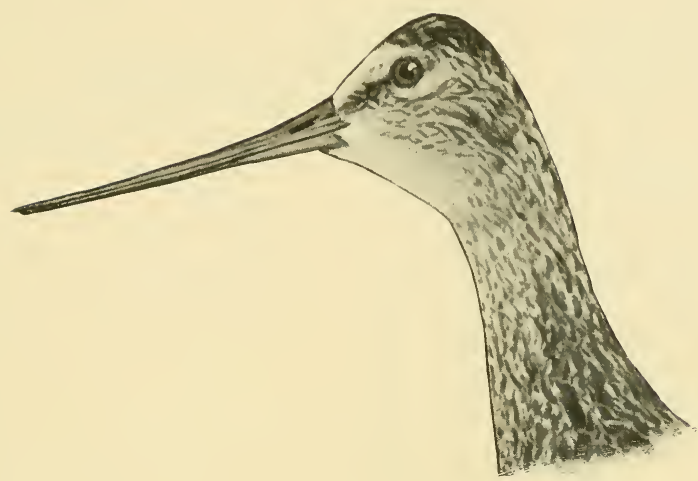

Limosd ledod.

Length 15.25: Wing, 8.10; Tarsus, 2.30; Bill, 3.30. Under parts rufous brown or chestnut brown barred with dusky black; bill slightly curved upward : axillars black.

Limosa hæmastica.

Hudsonian Godwit. See page $28 z$

\section{Length over 13 ; wing over 7 ; bill under 2.75 ; toes four in number.}

Length, 14: Wing. 7.60: Tarsus. 2.60: 13ill, 2.30. Biil black, nearly straight; legs yellow ; primaries blackish.

Length 16; Wing, 8.50: Tarsus, 2.60; Bill, 2.30. Bill black, nearly straight: prominent white patch on wing; legs grayish; axillars black.

Length, 16: Wing. S.60: Tarsus, 2.65: Jill. 2.40. Slightly larger, but very similar to preceding.
Totanus melanoleucus.

Greater Yellow=legs.

Winter Yellow=legs. See page $2 s_{3}$

Symphemia semipalmata.

Willet. See page $2 \mathrm{~S}_{5}$

Symphemia semipalmata inornata.

Western Willet. See page $2 \$ 6$ 


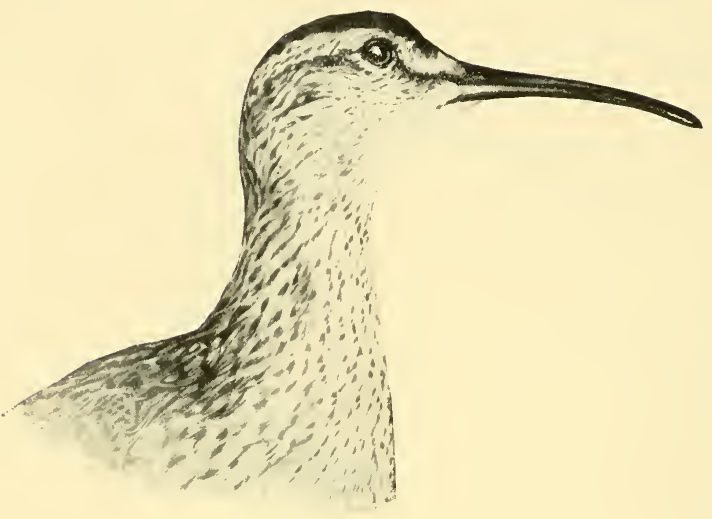

Numenius hudsonicus.

Length, 14; Wing. 7.40: Tarsus, 2.50: Bill, 2.15.

Rump and upper tail coverts and crissum pure white: bill nearly straight: somewhat resembles a lellow-legs, but has olive green legs.

Totanus nebularius.

Green=shank. See page $2 S z$

length, 13; Wing, S.25: Tarsus, 1.75; Bill, 2.30.

Bill curved downward: plumage mottled brown streaked with brown: top of head dark brown : axillars barred.

Numenius borealis.

Eskimo Curlew.

Dough=bird.

See page $29^{\circ}$

FAMIL CHARADRIID.E. PlOVERS.

Length over 9 ; wing over 6 ; toes four in number.

(The hind toe so small as hardly to be noticeable.)

Length, 11.50; Wing. 7.50: Tail, 3: Tarsus, r.9o;

Bill, 1.10. Bill thick; axillars smoky black.

Charadrius squatarola.

Black=breast Plover.

Beetle=head.

See page 290 


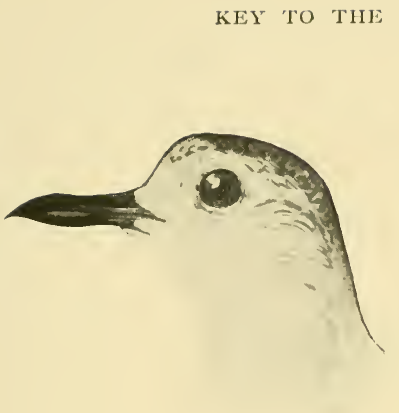

Charadrius squatarola (winter).

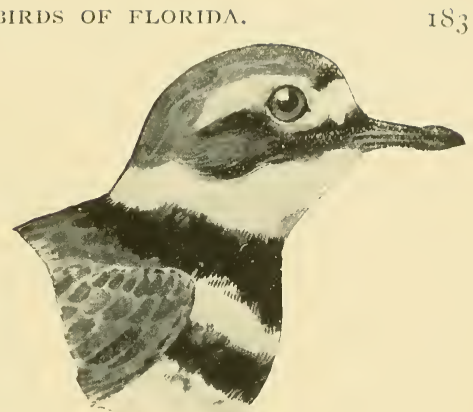

Ægialitis vocifera.

Length over 9 ; wing 6 or over; toes three in number. (No rudimentary hind toe.)

Length, 9.50: Wing. 7; Tail, 2.50; Tarsus, 1.65; IBill, .90. Axillars gray.

Charadrius dominicus.

Golden Plover. See page 292

Length, 10.30: Wing, 6.50: Tail, 3.50: Tarsus, 1.30: Bill, .8o. Rump rufous brown.
Agialitis vocifera.

Killdeer Plover. See page 292

Length under 9 ; wing under 6 ; toes three in number.

Length. 8.10: Wing, 6: Tail, 2.60: Tarsus, 1.50 ; Bill. .So. Above grayish brown : under parts dull white; buffy white on breast. In summer, front of crown and loral streak black. In winter, no black on head.

Length, 7.70: Wing. 4.40: Tail. 1.90: Tarsus, I.25 : Bill, .so. Bill large. black: a band of black or brown on the breast.

Length, 7 : Wing. 4.50; Tail. 2: Tarsus, .So; Isill, .50. Bill orange at base : legs yellow; no black stripe from bill to eye.

Length, 7.10: Wing, 4.75; Tail, 2.25; Tarsus. .90: Bill. .50. Bill orange yellow at base; a black stripe from the bill passing under the eye; toes with small web.
Agialitis montana.

Mountain Plover. Sec page 295

Egialitis wilsonia.

Wilson's Plover. Siec page 294

Agialitis meloda.

Piping Plover. Sec page 294

Egialitis semipalmata.

Ringeneck Plover. See page 2y) 3 
Ist KEY TO THE WATER BIRDS OF FLORIDA.

FAMIL APIIRIZID.E. SURF BIRDS IND TIRNSTONES.

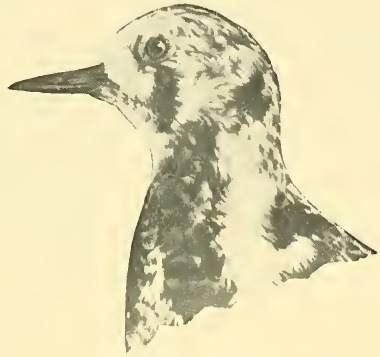

Arenaria interpres.

Length, 8.60; Wing, 5.70; Tail. 2.60: Tarsus, I ; Bill, .95.

Arenaria interpres.

Turnstone.

Sce page $29^{\prime}$,

\section{FAMILY II.EMATOPODID,E. OrSTER-CATCHERs.}

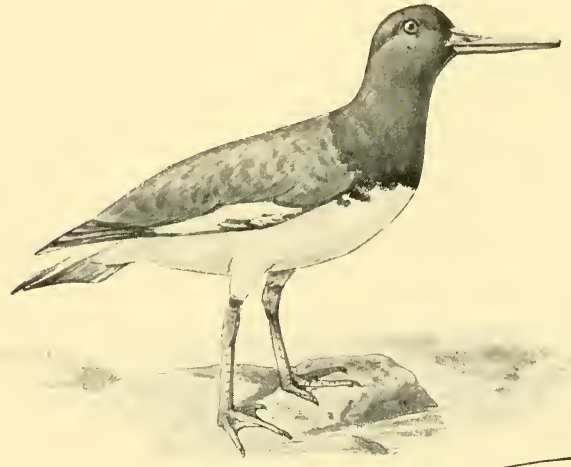

Hæmatopus palliatus.

Length, 18.50; Wing, 10.50; Tarsus, 2.35; Bill, 3.50. Head, neck, and back black; under parts white; bill orange red in winter, deep red in summer.

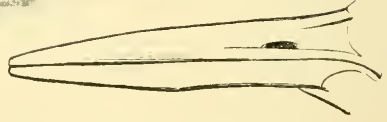

Hæmatopus palliatus (bill).

Hrematopus palliatus. Oyster $=$ catcher. See page 296 


\title{
ORDER PYGOPODES.
}

\author{
DIVING BIRDS.
}

\section{Fanily POdicipid,E. Grebes.}

\section{Genes COLYMBUS Linn.}

\section{COLYMBUS AURITUS I.inn. \\ Horned Grebe.}

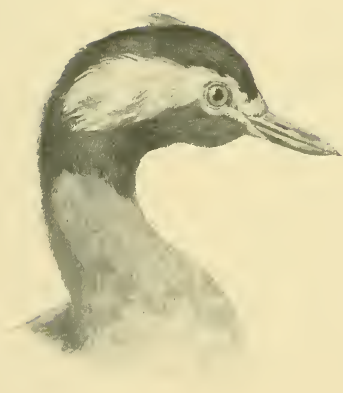

Adult in summer: Upper parts, including back, wings. top of the head and back of the neck, glossy black: throat black: front of the neck, breast, and sides of the body rufous chestnut; rest of under parts white: wings dusky black: secondaries white: lores dull chestnut; the two small tufts of feathers at the sicles of the occiput brownish buff.

Adult in winter and immature: Head and back grayish, under parts white, usually tinged with gray on the breast and lower throat: no tufts on sides of the head in winter plumage.

Length, 13.40: Wing, 5.40: Tarsus, 1.70 : Bill, . $S_{5}$ to .95.

The Horned Grebe is not uncommon on the Atlantic coast during the migrations, breeding from the Northern L nited States northward and migrating in winter south to Florida and the Gulf sitates.

The nest is constructed on floating debris: eggs, four to seven, dull white or yellowish white.

Range: “. Northern Hemisphere : breeds from United States northward." 


\section{Gexus PODILYMBUS Lersox.}

\section{PODILYMBUS PODICEPS (Limn.).}

\section{Pied=billed Grebe .}

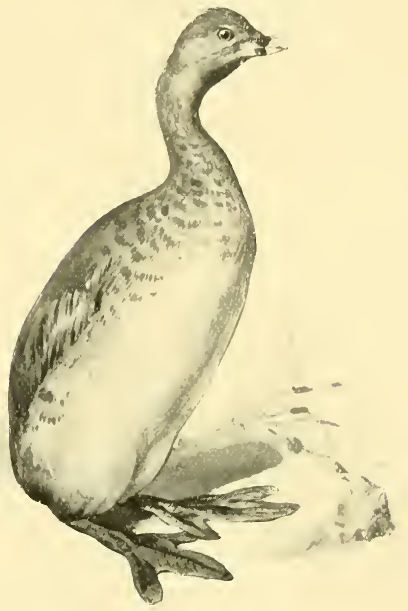

Adult in summer plumage': Throat black, and a black band on the bill; no tufts on sides of the head in any plumage. H'inter-plumage: Throat grayish white, no black band on bill: sides faintly washed with pale brown.

Length, 13.50: Wing, .5: Tarsus, 1.45; Bill, .90.

Often confounded with the preceding species in winter dress.

Florida in winter: not very common. It occasionally breeds in the State.

Rancre: British Provinces of North America to South America. Nests on floating vegetation or slightly submerged marshes: eggs three to eight, vellowish white or dull white in color. 


\section{F.MILY TRINATORID.E. LOONS, DINIRS. GENTS URINATOR C'TIER.}

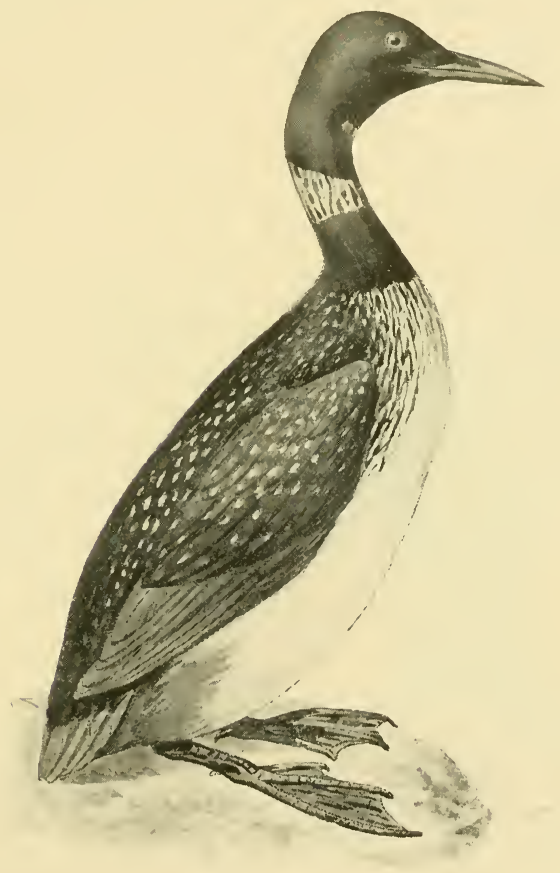

\section{URINATOR IMBER (GInn.).}

\section{Loon. Great Northern Diver.}

Adult in summer: Head and neck black, showing green in some lights. A patch of white streaked with black on the throat and sides of the neck; under parts white; back streaked 
and spotted with white. Il inter plumege : Head grayish. throat white or grayish white. wings and back not streaked or spotteel.

Length. 31: Wing. 14: Tarsus. 3.35: Bill. 2.75.

I winter visitor to Florida, ranging from the far Dorth. south to the (iulf of Mesicos. It breeds from the northern Enited siates northward. The exss are gravish or wreenish hrown, heavily blotehed with dark brown : they are usually two in mumber. deposited on the gromol : the next consists merely of a little grass or dried weeds.

\section{URINATOR LUMIME (}

\section{Red=throated L.oon. Red=throated Diver.}

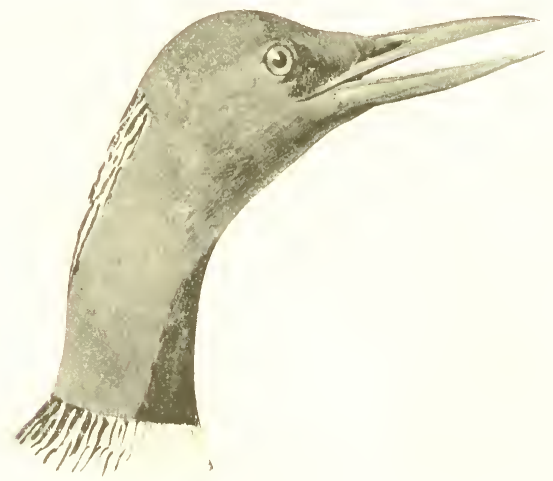

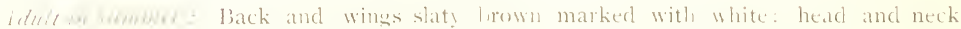

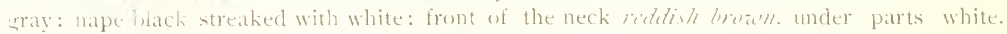

felult in ainter: Throal white or grayish white; hatk showing white spots.

Leneth. 24.50: Wing. 11.25: Tarsus. 2.50: Bill. 2.

Florida in winter: not uncommon on the coast. Breeds from the Northern L nited sitates northwarel. It ranges in winter to the Gulf of Mexico. The egres are two in number. which are deposited on the ground near water, the nest being merely a little grats : they are olive hrown in color. blotehed with dark bown or blatek. 


\section{ORDER LONGIPENNES.}

Lovg-Wixged Swimares.

\section{FAMILY STERCORARIID.E. J.egers. GENUs STERCORARIUS Brision.}

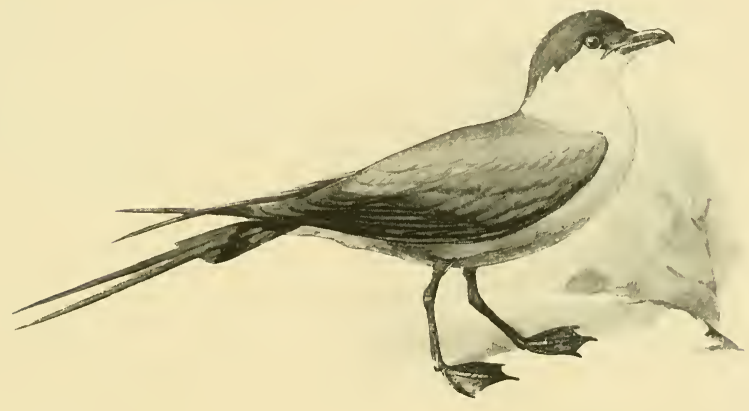

STERCORARIUS PARASITICUS (Limn.).

Parasitic Jager.

Length from base of hook on end of bill (unguis) to frontal feathers greater than from unguis to tip of upper mandible.

Adult (light phase of plumage): upper parts slaty gray, a tinge of pale yellow on the sides of the head and neck. Crown of the head and lores sooty black; under parts white, shading into slaty gray on sides and lower belly: two middle tail feathers pointed. brown.

Adult (dark phase): general plumage sooty brown; slightly paler below : crown dark

Immature (light phase): head and neck streaked with buff or gray: under parts mottled and barred with slaty gray; upper parts dark gray: some of the feathers edged with buff.

Immature (dark phase): general color slaty brown : neck marked with white; feathers on the belly barred with dull white. In all plumage the two middle tail feathers are pointed, and the tarsus is black in freshly killed specimens.

Length, 17 to 20 : Wing, $1_{3}$ : Tail (adult), 8.40, (immature). 6: Tarsus, 1.60: Bill, 1.20. 
Accidental on the Florida coast in winter. It ranges from the far North southward to South America and South Africa. It breeds in high northern latitudes. The eggs are olive brown, blotched with chocolate brown. The nest is a little grass in a slight depression in the ground.

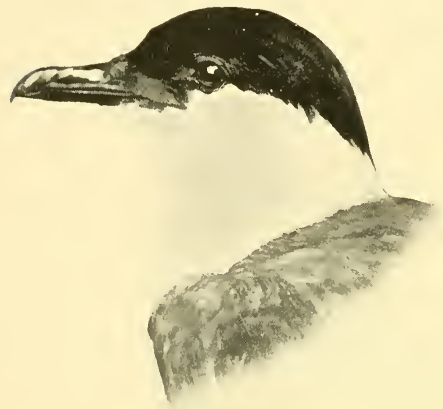

Stercorarius parasiticus (adult).

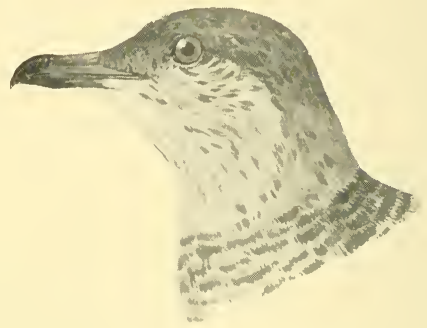

Stercorarius parasiticus (immature).

\section{STERCORARIUS LONGICAUDUS Iicill. Long=tailed Jaeger.}

Length from base of the hook on end of upper mandible (unguis) to frontal feathers less than from unguis to tip of upper mandible; tarsus blue in freshly killed specimens, feet black.

Adult; Above slaty gray; top and sides of the head dull black : sides of the head and neck pale yellow : under parts lark slate color : chest and upper belly whitish.

Immature: Resembles the preceding species in color: but may be distinguished by comparing the measurements of the bill and tail.

Length, I9 to 23; Wing, I2.50; Tail (adult), I2.50 (immature), 6; Tarsus, 1.65; Bill, r.ı.

It breeds in high northern latitudes, ranging southward in winter to the West Indies and Gulf of Mexico. The eggs are three in number, pale olive brown blotched with chocolate brown. It nests on the ground.

A bird of this species was found dead on the beach, a short distance north of Cape Canaveral. I have never seen it alive in Florida. 


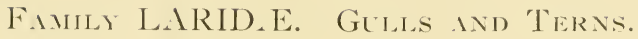

\author{
SLEFAMILY LARIN.E. GuLLS.
}

\section{GENe's LARUS LINN.}

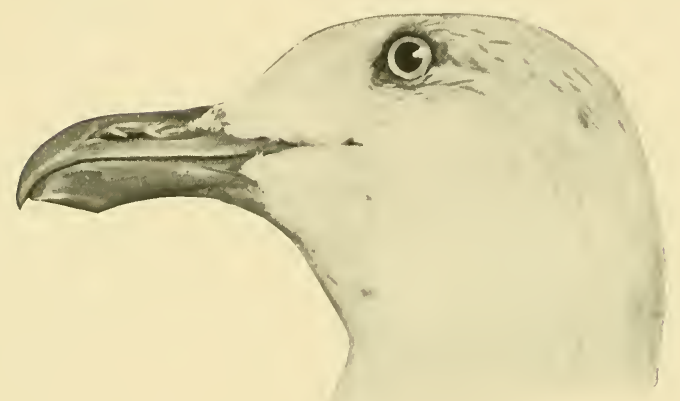

\section{LARUS MARINUS Linn.}

\section{Great Black=backed Gull.}

Adult in summer: Whole back dark slate color; outer primaries black. with tips and terminal spots of white: head and under parts white.

Adult in winter: Head and neck streaked with gray. Immature birds are mottled dusky and buff: head and neck streaked: tail with narrow subterminal band; a very large gull.

Length. 29: Wing, 18: Tail, S: Tarsus, 2.70; Bill, 2.40.

Coast of North America south to South Carolina: accidental in Florida. Breeds from Northern Maine northward. The nest is built on the ground; the eggs are usually two, pale brown, marked with chocolate brown.

A specimen of this gull was shot near St. Augustine during the winter of $189+-5$. 


\section{LARUS ARGENTATUS SMITHSONIANUS Con's. American Herring Gull.}

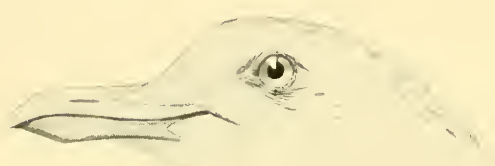

White near end of outer primary separated from the white tip by a band of black.

Adult in summer: Back pearl gray; head. neck, and under parts white; in winter the adult has the head and neck streaked with ashy gray. First primary tipped with white with a subterminal band of black: this, in turn. is followed by a white band and then another black one.

Immatme: (ieneral plumage mottled pale brown or buff.

Length, 24: Wing, 17.50: Tail. 7.50: Bill, 2.10 .

The European species, Larus argentatus. is very similar, but has the two white marks at tip of primary joined and not separated by the black.

Ranges throughout North America: common in Florida in winter. It breeds from Maine northward. Nest constructed of grass or seaweed, usually on the ground: eggs brownish white, lined and blotched with dark brown.

\section{LARUS DELAWARENSIS Ord. Ring-billed Gull.}

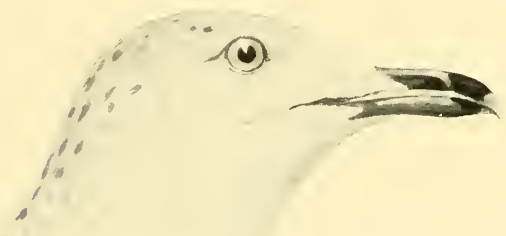

Actult in summer: Bill yellowish banded with black; mantle pearl gray ; feet pale yellow or greenish ; first primary black with a subterminal white spot. In winter, head and neck streaked with dusky: band on bill less distinct.

Immature: (ieneral plumage mottled gray or buff gray; bill yellowish tipped with black.

Length. 1s.4o: Wing, 14: Tail, 6: Bill. 1.65 .

Ranges throughout North America, in winter south to Gulf of Mexico. Not uncommon in Florida. Nests on the ground; eggs pale butf marked with chocolate brown. 


\section{LARUS ATRICILLA Linn. Laughing Gull.}

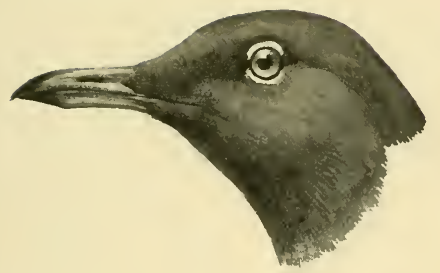

Adult in summer: Head and throat plum= beous ; rest of upper parts pearl gray; under parts white; bill reddish.

Adult in winter: Head white marked with ash gray: throat white.

Length, 16.50; Wing, 12.50; Tail, 5; Bill, 1.75 .

This species has a wide breeding range, extending from Maine to the Gulf of Mexico. It is resident and breeds in Florida. The nest is built on the ground in marshy places, and the eggs, usually four or five, are grayish or pale brownish, blotched with chocolate brown.

\section{LARUS PHILADELPHIA (Ord). Bonaparte's Gull.}

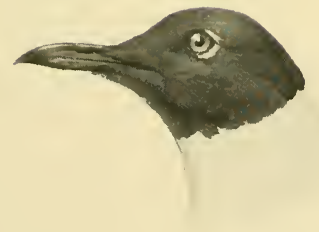

Adult in summer $\because$ Bill black; head and neck plumbeous : feet orange red; tail white.

Adult in winter: Head and neck white: top of the head grayish ; feet flesh color.

Immature birds have a white tail with subterminal band of black.

Length, 13.50; Wing, 10.40; Tail, 4.15; Bill, 1.30.

North America, south in winter to Central America and $W^{\top}$ est Indies. Common in Florida in winter. Breeds far northward. Nest composed of brush and grass built in small trees or bushes. Eggs four, pale olive, marked with brown spots. 
Subfamly STERNINE. Terns.

\section{Genes GELOCHELIDON Breim.}

\section{GELOCHELIDON NILOTICA (Hasselq.).}

Gull=billed Tern.

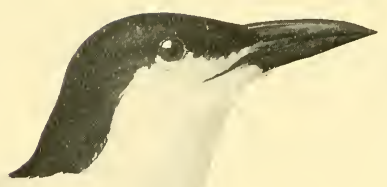

Adult in summer: Top of head and nape black; upper part, including rump and tail, pearl gray: under parts white; bill and feet black, the former comparatively short and stout.

Adult in winter: Similar, but having the head and neck white, the nape ashy, and a dusky patch in front of the eye.

Length, 14; Wing, 12: Tail, 5.50; Bill, 1.40; Tarsus, I.30.

A most widely distributed cosmopolitan species. It is common in Florida and probably breeds in the State. It occurs commonly on the middle Atlantic coast in summer where it breeds, and occasionally wandering as far north as Maine. The eggs are usually three in number, pale brownish white, faintly mottled with brown, deposited in a slight depression in the sand.

\section{Genus STERNA LiNN. \\ STERNA TSCHEGRAVA Lepech. \\ Caspian Tern.}

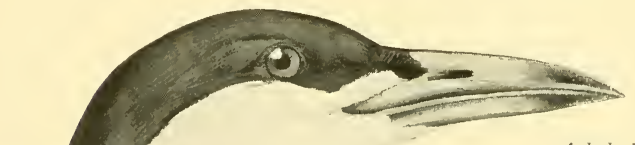

Adult in spring: Bill deep red ; top of the head black, rest of upper parts pearl gray: pri= maries dark slate color on inner webs, hoary on outer webs ; tail grayish white; feet black.

Adult in winter: Top of the head streaked with black; tail showing brownish bars.

Length, 21; Wing, I6; Tail, 6.10; Bill, 2.60; Tarsus, ז.5०.

According to Mr. Scott, the Caspian Tern occurs in Florida.* I have never met with it in the State; it is known to breed on the Virginia coast, and probably is a regular summer risitant to Florida.

* Since the above was written, a bird of this species was killed in March near the head of the Banana River by Mr. T'. Watson Merrill, of Boston. 


\section{STERNA MAXIMA Boil. \\ Royal Tern.}

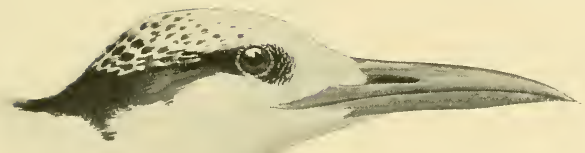

Length, 19; Wing, 14: Tail, 7: Tarsus. 1.35: Bill, 2.60.

Tropical America, occasionally wandering as far north as New England. It is common in Florida, breeding in the State. It breeds commonly on the middle Atlantic coast, having been found breeding in numbers on the coast of Virginia. The eggs are two to four, dull white, mottled with chocolate brown.

Range: .. Tropical America and warmer parts of North America northward to Massachusetts, the Great Lakes, and California, west coast of Africa north to Tangiers."

\section{STERNA SANDVICENSIS ACUFLAVIDA (Cabot). Cabot's Tern.}

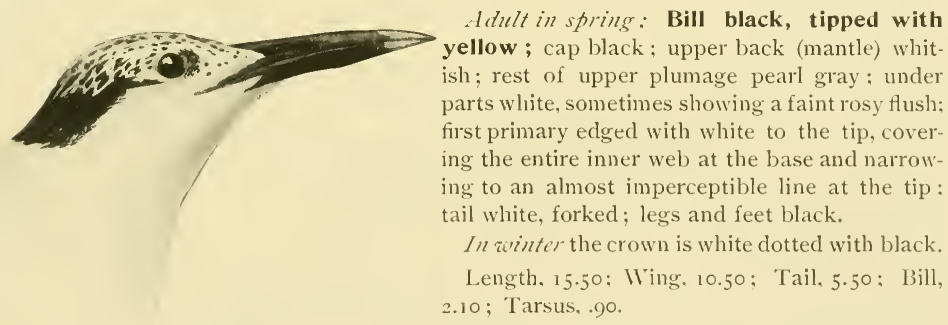

This species occurs in Floricla throughout the year, but is much more abundant in summer than in winter. It breeds on both coasts of Florida: the eggs are pale brownish white. streaked and spotted with brown.

Range : " Tropical America, northward along the Atlantic coast irregularly to Southern New England." 


\section{STERNA FORSTERI Nutt.}

\section{Forster's Tern.}

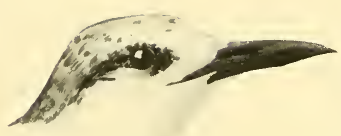

Adult in summer: Crown black: upper parts pearl gray : under parts white: inner web of outer tail feather darker than outer web ; bill reddish orange tipped with black: feet yellowish. Adult in winter: Bill dark brown : feet brown; head grayish ; a dusky black patch on sides of the head. enclosing the eye. Immature in winter : Upper parts mottled with pale brown or buff.

Length, 15; Wing, 10.25; Tail, 6.60: Tarsus, .90; Bill. 1.50 .

The range of Forster's Tern extends nearly throughout North America. It is common in winter in Florida, both on the east and west coast. It breeds commonly on Cobb's Island, Va.; the eggs are two to three in number, usually laid on the sand; they are pale buff or greenish gray marked with dark brown.

\section{STERNA HIRUNDO Limn.}

\section{Common Tern. Mackerel "Gull."}

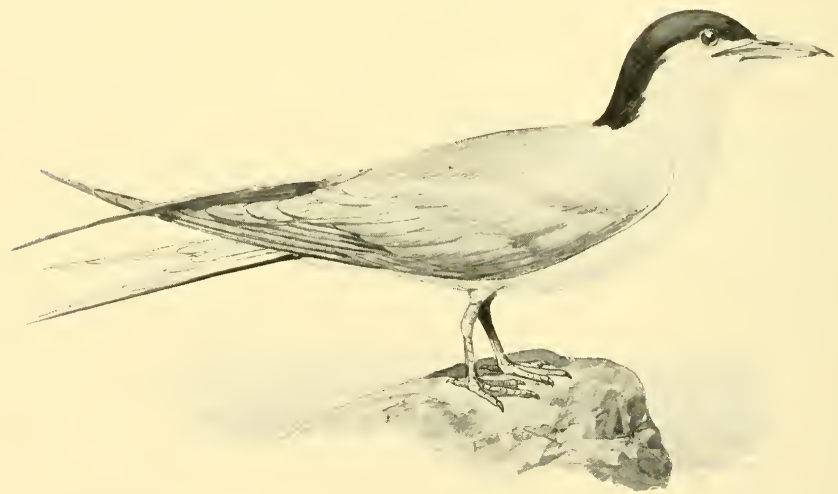

Adult in summer: Bill red, broadly tipped with black: feet red; crown black ; upper parts pearl gray; under parts pale ashy gray. Adult in winter : Forehead and crown white or grayish white: under parts white. Immature specimens have the upper parts mottled with buff or pale brown. The outer web of outer tail feather is darker than the inner web at all seasons. 


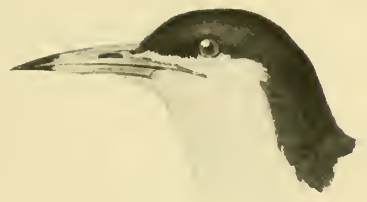

Length, 15; WVing, 10.30: Tail, 5.50: Tarsus, .75: I3ill, I.45.

A widely distributed species not uncommon in Florida in winter. It breeds commonly along the Atlantic coast: the eggs are three in number, grayish or buff white, marked with chocolate brown.

\section{STERNA DOUGALLI Montag.}

\section{Roseate Tern.}

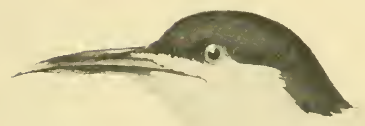

Atnlt spring plumage: bill black, tinged with red at base : slender ; cap black : upper plumage pearl gray : under parts white, tinged with pink when freshly killed. Tail entirely white; outer feather longer than the others: legs vermillion red; iris brown. Idult in winter: Forehead whitish or grayish white; occiput and upper nape black. Immature specimens have the upper parts mottled with gray and buff.

Length. 15: Wing. 7.75: Tail, 7.50: Tarsus, .s5: Bill, 1.55 .

A common species on the Atlantic coast. It is resident and breeds in Florida, ranging in summer north to New England.

The eggs are three in number, pale, buffy gray or gravish white marked with chocolate brown.

\section{STERNA ANTILLARUM (Less.). \\ Least Tern.}

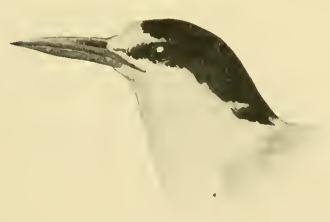

Adult in summer: Bill yellow, tipped with black: forehead white : crown and lores black: upper parts pearl gray : under parts white: outer primaries brownish black on outer webs and inner half of inner webs: tail white: feet orange yellow.

Adult in winter: Forepart of crown white, marked with black: occiput black. Immature birds have the upper parts mottled with buff and the bill dark brown.

Length. 9.50: Wing. 7: Tail, 3.50: Tarsus, .60: Bill, 1.20.

This is the smallest of the Terns. It is resident in parts of Florida and breeds in the State. The eggs are three, sometimes four, pale buff or brownish white dotted with brown. 
Range: "Northern South America northward to California and New England and casually to Labrador, breeding nearly throughout its range."

\section{STERNA FULIGINOSA Gmel. Sooty Tern.}

(A.O.U.)

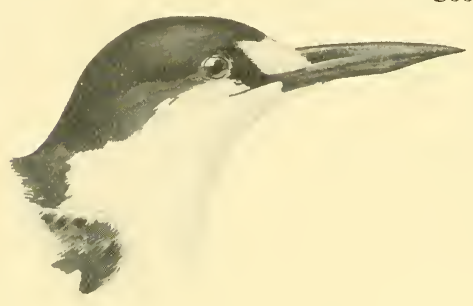

Adult in summer: Bill black: crown and entire upper plumage black; dusky on the nape: forehead white, extending back in a pointed streak from the sides of the forehead. but not reaching above the eye; under parts white; outer tail feathers white, shading into dark brown on the inner web near the tip: legs and feet black.

Length, т6.50: IVing, Ir.50; Tail. 7 ; Tarsus. .90 : Bill, г.60.

The Sooty Tern is common along the coast of Southern Florida in summer. It probably breeds in Florida, as it does so in large numbers in the Bahama Islands. Eggs usually two, buff white marked with chocolate brown.

Range: "Tropical and sub-tropical coasts of the globe."

(A.O.U.)

\section{STERNA ANAETHETUS Scop.}

\section{Bridled Tern.}

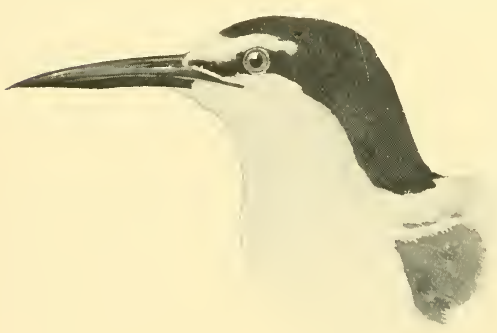

1dult: Spring plumuge, bill black; cap black; forehead white, extending in a stripe on both sides of the foreliead over and beyond the eye ; upper back (mantle) grayish, shading into white on the sides of the neck; wings grayish brown, under parts white; primaries dark brown, the first and second showing a stripe of white on the inner webs not reaching the tips; upper tail coverts slaty gray : outer tail feathers almost entirely white, showing a slight tinge of brownish near the tip; legs and feet black.

Length, 14.25; Wing, Io; Tail, 6.25; Tarsus, .70; Bill, I.50.

The Bridled Tern is a tropical species which is accidental on our coast. It has once been taken in Florida and probably will be found to occur regularly in summer. I found it breeding in the Bahama Islands in June, I 879 , in company with the Sooty Terns. The eggs are usually two, cream color or brownish white blotched with chocolate brown. 


\section{GeNe's HYDROCHELIDON BoIE.}

\section{HYDROCHELIDON NIGRA SURINAMENSIS (Gmel.)}

\section{Black Tern.}

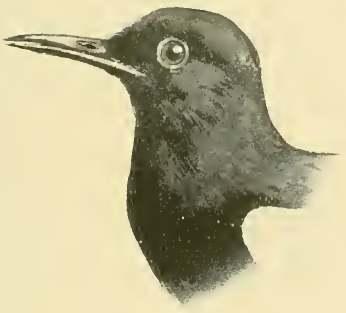

ddult in summer: Upper parts slaty gray; head and under parts black (except under tail coverts) : bill and feet black. Adult in winter: head white, with a black patch streaked with white on the occiput; upper parts gray. Immature: upper parts nottled with buff or pale brown; sides ashy.

Length. 9.50: IVing, 8.30: Tail, 3.60: Tarsus, .70: 13ill, I.10.

The Black Tern occurs on the Atlantic coast from Florida to Prince Edward's Island, and on the west coast from Alaska to Chile. It breeds from the middle United States northward. The eggs are olive brown blotched with pale brown and chocolate brown.

\section{Genus ANOUS Stephens.}

\section{ANOUS STOLIDUS (Limn.). Noddy Tern.}

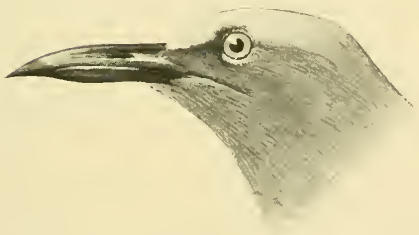

Adult in summer: Bill black; forehead white, shading into gray on the occiput; lower eyelid white : front of the eye, and narrow superciliary line blackish: general plumage rich olive brown; primaries dark brown, the first having the inner web pale brown; legs and feet black. The immature birds have the head grayish brown, whitish on the forehead.

Length, 15: Wing, 10; Tail, 5.75; Tarsus, .80 : Bill, 1.70.

The Noddy Tern is a summer visitant to our Southern shores, and breeds in Florida on some of the Southern keys. It is abundant in the Bahama Islands and breeds there in June in great numbers. Only one egg is usually: laid: but I have found two in a nest on several occasions. The nest, which is constructed of sticks and grass, is built (on the Maraporvos Islands, Bahamas, ) upon the low cactus plants which cover the islands. Occasionally an egg was found in a depression of the rock without any nest. The eggs are buff white marked with reddish brown. 


\section{FAMILY RIITX'IIOPID.E. SHMMMER. (inis RHYNCHOPS Im.}

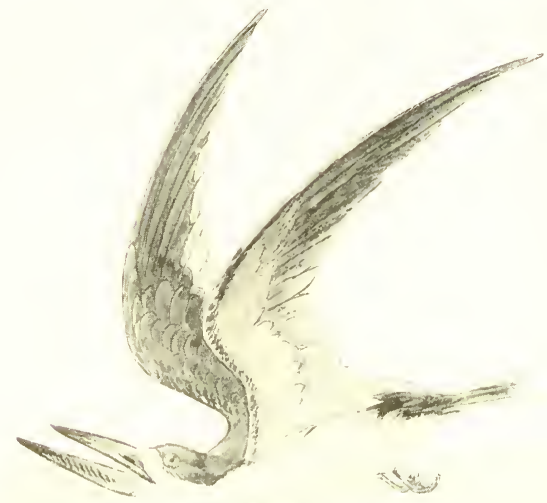

\section{RHYNCHOPS NIGRA l.im.}

Black Skimmer.

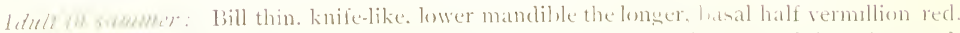
blackish at tip : forchead, lores. and cheeks, and entire under part to crissum. and tips of secondaries white: under lining of wing and axillars white: rest of plumage lolark: tait white. the shafts of the feathers lownish above.

folult in alnte: Similar but browner. and showing a white nuchal collar.

Length. 1sto 20: Wing. 15: Tail. 5.50: Tarsus, 1.25: 13ill (culmen). 2.70: (ionys. 4.25.

I common resiclent in Floridat, it breeds on the Ithantic coast from Florida to Virginia. The egess, usually four, are brownish white blotehed with chocolate brown: they are deposited on the sand without any nest.

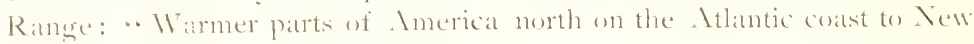
Jerser and castably to the bay of Fundy." (.1.0.1.) 


\section{ORIDER TUBINARES.}

Tube-Nosen Swimmers.

Fanily DIONEDEID.E. Albatrosses.

GENe's DIOMEDEA LiNN.

\section{DIOMEDEA EXULANS Limn. \\ Wandering Albatross.}

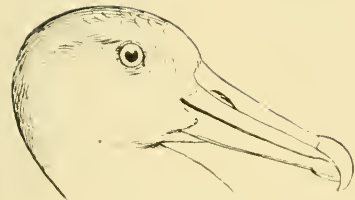

(Very much reduced.)

Adult : General color yellowish white; remiges dusky ; bill white, pale yellowish at tip. Immature birds are dark brown, showing whitish on the forehead and face.

Length about 4 feet; extent of wings (spread) about 10 to 12 feet.

The only claim this species has to be included among our birds is the alleged capture of a specimen in Tampa Bay, Florida. It is an Antarctic species.

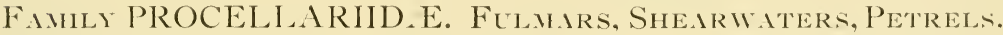

Gents PUFFINUS Brisson.

PUFFINUS MAJOR Faber.

Greater Shearwater.

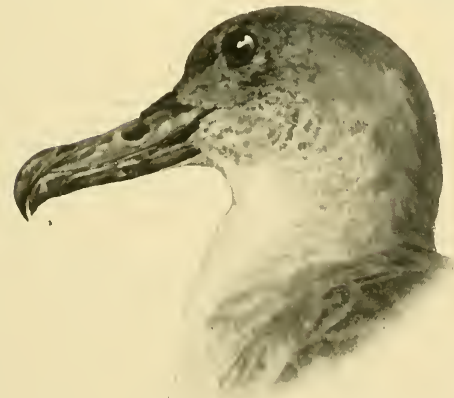

Adult: General plumage brown, grayish on the head: under parts and lining of wing white tail brown ; crissum dark; under tail coverts gray; tarsus dark in front, the rest pale.

Length, 19: Wing, 12.50: Tail, 5.75: Bill. 2.40 Tarsus, 2.

Ranges from Cape Horn and Cape of Good IIope to Greenland. I know of no positive record of the occurrence of this bird in Florida, but once saw a stuffed specimen in Jacksonville, which the dealer claimed was killed off the coast. 


\section{PUFFINUS AUDUBONI Finsch. \\ Audubon's Shearwater.}

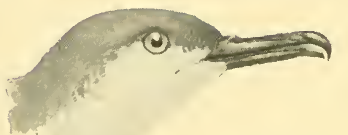

Adult: Above glossy brown, shading into grayish on the sides of the breast : below white: crissum brown and white; tail brown, the feathers tipped with ashy: bill plumbeous.

Length, 11.50: Wing. S: Bill, I.20: Tarsus, 1.55.

Occurs on the Atlantic coast from Florida to New Jersey : very common in the Bahama Islands, where it breeds: nest in holes in the rocks, where the bird lays a single chalky white egg.

\section{Gent's fESTRELATA Boxip.}

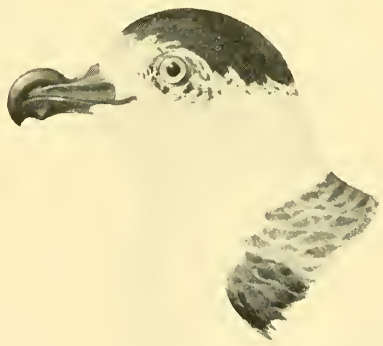

\section{AESTRELATA HASITATA $(K u h l)$. Black=capped Petrel.}

1dult: Head white; crown black; upper parts except upper tasl coverts dusky : under parts white; sides of the chest sometimes gray. Upper and under tail coverts white.

Length, 16.50: Wing, 12: Bill, 1.35; Tarsus, I.40.

An Atlantic species rarely found near the coast. It has been taken in "Florida and on Long Island." (Ridgzay, Man. .1. 1. Birds, t. 66.) 


\section{Genes OCEANITES Kers. AND Bi.As.}

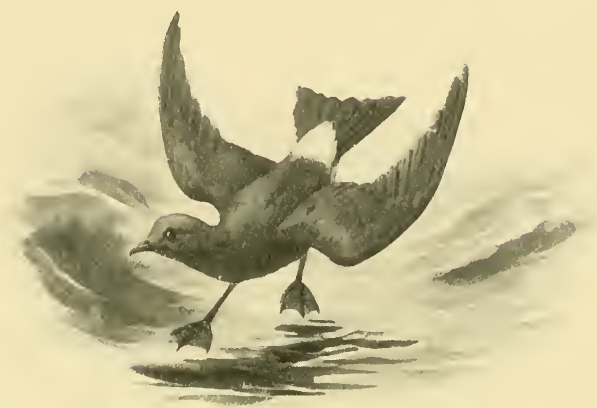

OCEANITES OCEANICUS $(K \nVdash u h l)$.

Wilson's Petrel. Mother Cary's Chicken.

Adult: General plumage dark brown ; wing coverts edged with pale brown: part of upper tail coverts white ; tail black; bill black: legs and feet black; yellow spots on the webs between the toes.

Length, 7 ; Wing. 5.60; Tail, 2.45: Tarsus, 1.25; Bill, .6o.

Common off the Atlantic coast in summer. It ranges throughout the "North and South Atlantic and Southern Oceans." (.1.O.t.)

\section{GENis CYMODROMA RIDGIII.}

\section{CYMODROMA GRALLARIA ( Tieill.).}

\section{White=bellied Petrel.}

Upper parts dusky, under parts white.

" Throat usually with only concealed white and without white on the hind neck."

Length, 8; Wing, 6.25: Tail, 3.10; Tarsus, 1.50.

“ Intertropical seas, north casually to coast of Florida."

$$
\text { (Ridgroul. Man. I. 1. Birds. p. 72.) }
$$




\section{ORDER STEGANOPODES.}

Totmpalmate Swmmers.

FAMILY PHAÉTHONTID. Troptc BIRDs. GeNus PHAËTHON Lixs.

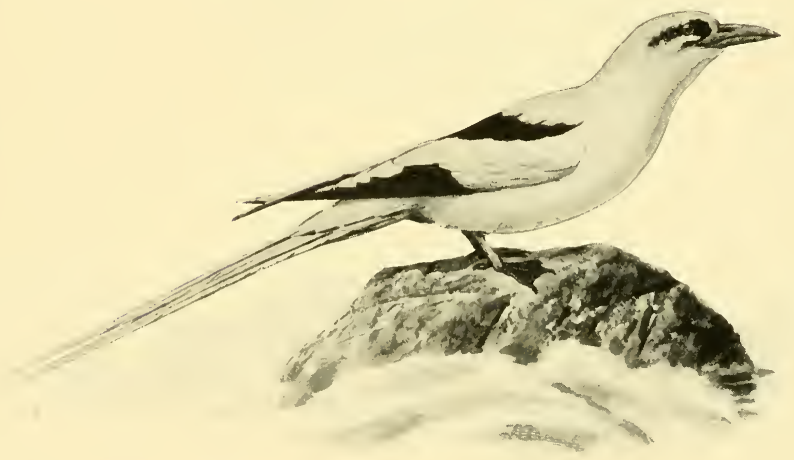

PHAETHON FLAVIROSTRIS Brandt. Yellow=billed Tropic Bird.

Adult: Bill pale orange yellow : general plumage white, sometimes slightly rose-tinted. most of the primaries showing much black; a black streak passing through the eve: some of the wing coverts and shafts of the tail feathers black: tail elongated into two very long feathers. which are slightly reddened: tarsus bluish: iris black: webs and toes black.

Length, including tail feathers, 31.50; Wing, 1 ; : Tail, 21 : Tarsus, .9o: Bill, 2.

The Yellow-billed Tropic Bird is of rare occurrence on our shores, but is common in the Bahama Islands, and has been recorded from Florida. 
F.mily SULID,E. G.INAETs.

GeNe's SULA Brissox.

\section{SULA CYANOPS Sunderit.}

Blue $=$ faced Booby .

Adult: General plumage white; remiges and greater wing coverts dark brown: middle rectices hoary white tipped with brown: rest of tail feathers dark brown. white at the base: feet reddish: gular sac bluish.

Length, 27: Wing, 16: Tail, 7.70: Bill, 3.90: Tarsus, 1.85.

This species is claimed to occur on the Florida coast, although it must be considered as accidental. It has been found breeding in the Bahama Islands.

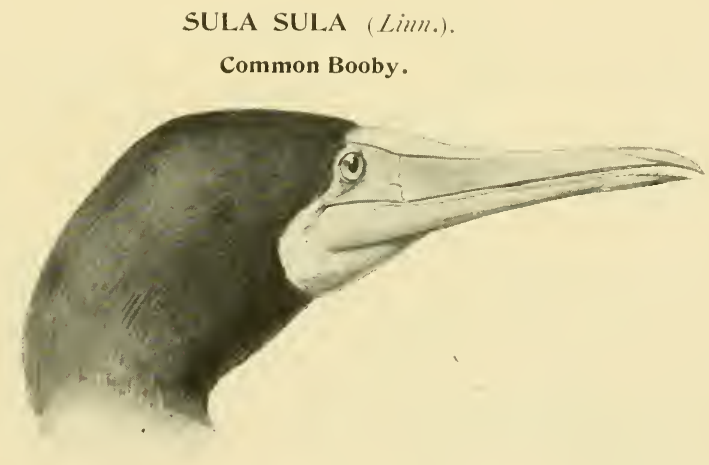

Adult: Head and throat, upper part of breast, and entire upper plumage dark olive brown, under parts white: gular sac pale yellow; upper mandible greenish: feet pale yellowish green; iris yellow.

Length, 27: Wing, 15.50: Tail. 8 : Tarsus, 1.60: Bill, 4 .

Claimed to have been taken in Florida, where it is probably accidental. It is not uncommon in the Bahama Islands, where it breeds. 


\section{SULA PISCATOR (Lim.). Red=footed Booby.}

Adult: General color white, showing a buff tinge on the head and neck. Shafts of the tail feathers pale yellow: remiges and most of the wing coverts slate-gray, showing an ash tinge; feet reddish. Immature: General plumage grayish brown above : dull gray beneath, sometimes whitish; plumage very variable.

Length, 27 ; Wing, 14.50; Tail, S; Tarsus, 2.10; Bill, 3.30 .

Range: "Coast and islands of tropical and sub-tropical seas north to Western Mexico and Florida."

(A.o.U.)

This species has very little claim to be included in our fauna. It may occasionally occur on the Florida coast in summer.

Subgents DYSPORUS Illiger.

\section{SULA BASSANA (Linn.). \\ Gannet.}

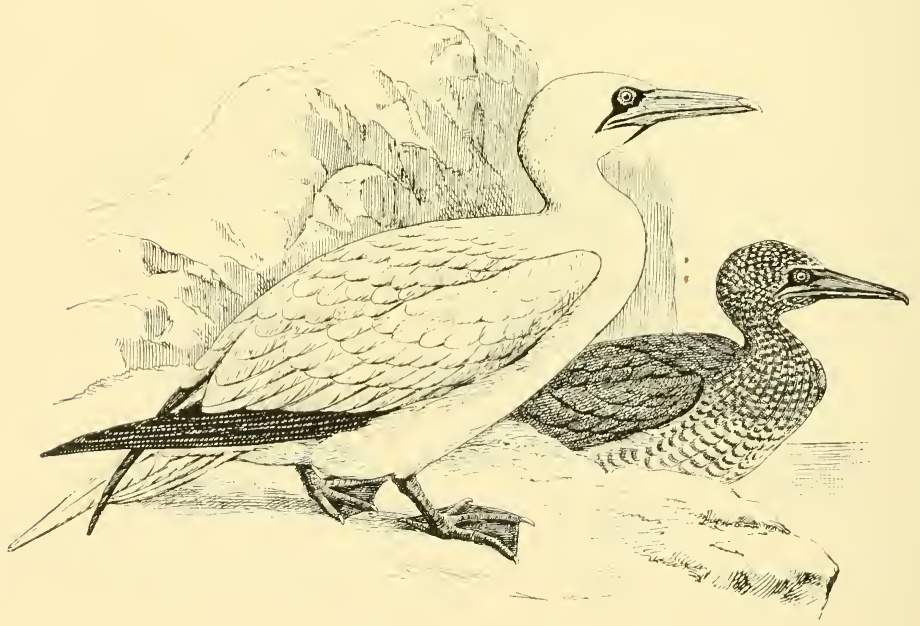

Adult.

1 mmature.

Adult: Very large: head and neck white tinged with yellowish buff : general color white ; primaries dark brown: loare space about the eyes, bluish black. Imnature: General plumage 
mottled, gray ish brown and white. showing wedge-shape white marks near the ends of the feathers. Length, 36; Wing, 19.25: Tail, 9.50: Tarsus, 2.20: Bili, 4.

The Gannet occasionally occurs in Florida in winter. It breeds from Nova Scotia northward, usually on rocky cliffs. The female lays one chalky-white egg. I found it breeding in great numbers on Bird Rock, Magdalene Islands in 1877 .

\section{FAMIIY ANIIINGID.E. DARTERS.}

\section{Gents ANHINGA Brisson.}

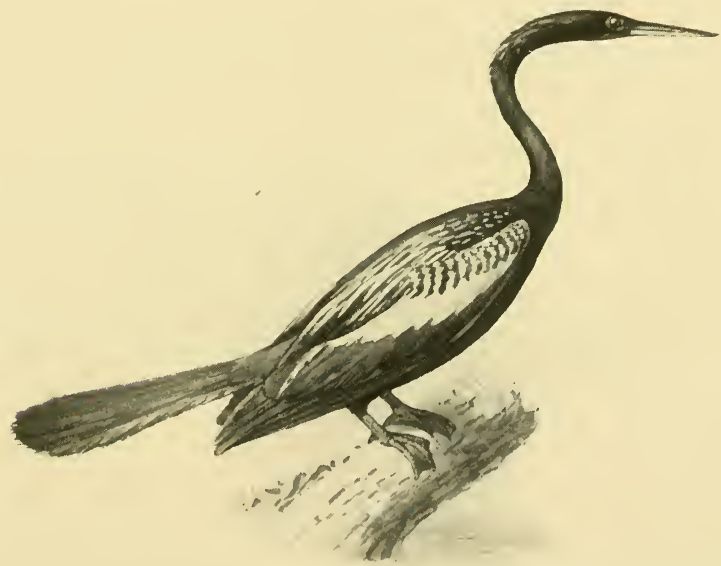

(Male.)

\section{ANHINGA ANHINGA (Limn.). \\ Anhinga. Water Turkey. Darter. Snake Bird.}

Adult male: Breeding plumage, head and neck black, showing a greenish gloss: back of the head and neck showing lengthened hair-like feathers of dull white: back mottled and streaked with white: upper mandible olive edged with yellow: lower mandible yellow. shading 
into green at the tip; gular sac yellow. In winter the male loses the white hair-like feathers on the neck: middle tail feathers showing transverse fluting.

Adult female: Head, neck, and breast buff color, darker on the nape.

Length. 33.50: Wing, 13.50; Tail. 10.50: Tarsus, 1.35: Bill, 3.25.

Ranges on the Atlantic coast from Florida to the Carolinas. It is resident and eds in Floricla, building its nest on some limb overhanging water. The eggs are usually two or three and chalky white, having a bluish tinge.

\section{FAMIIY PHALACROCORACID.E. CORMORINTS.}

\section{Genes PHALACROCORAX Brissox.}

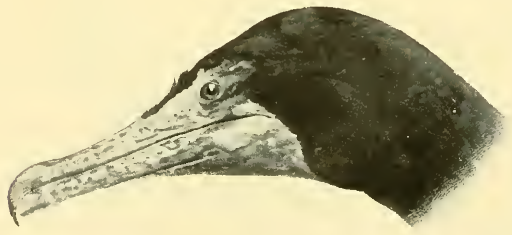

PHALACROCORAX DILOPHUS FLORIDANUS (Alud.). Florida Cormorant.

Adult in summer: General plumage black : back and wing coverts slaty brown : tail consists of twelve feathers.

Length, 36: Wing, 12: Tail, 5.75: Bill, 2.20.

Common on the Florida coast. It breeds in the state, the nest being built on bushes or trees. The eggs are dirty white with a bluish tinge. 
Family PElechinide. Pelicans.

\section{GeNus PELECANUS LINN.} Subgenus CYRTOPELICANUS RE1Ch.

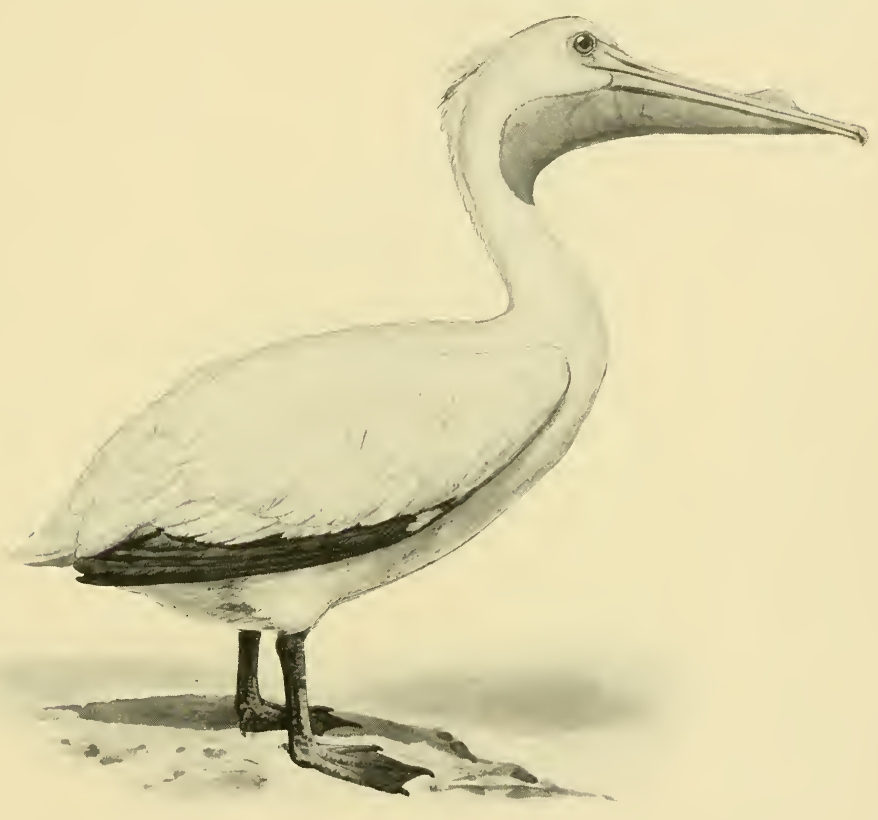

PELECANUS ERYTHRORHYNCHOS Gmel. American White Pelican.

Idult in breeding plumage: General plumage white: bill yellowish with horny protuberance on the top (this is lacking in winter): primaries black: pouch is lemon yellow and the legs pale yellow ; iris straw color.

Length, 60: Wing. 24.50; Tarsus, 4.45: Bill, 12.

The White Pelican is common in Central America and on the coast of California and Mexico; it occurs regularly in Florida, and is not uncommon in some localities, but its numbers are decreasing every year. It has been known to breed in the State : but does not do so regularly, as it is usually a winter visitant to Florida. 


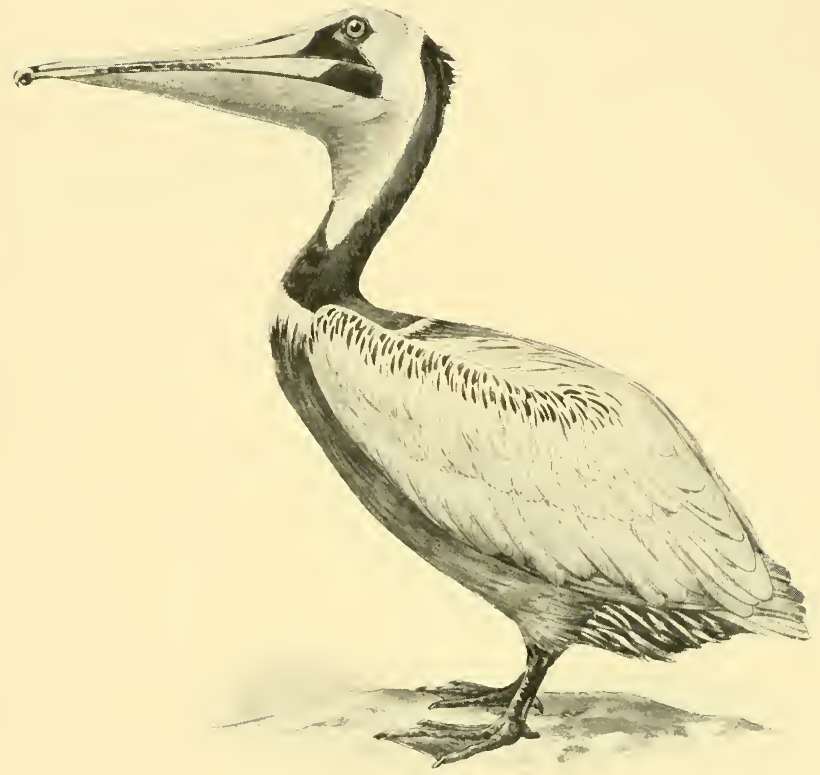

\section{PELECANUS FUSCUS Lim. Brown Pelican.}

Adult in breeding plumage: Neck chestnut brown; head and line at the base of the pouch yellowish white; upper parts ashy gray, some of the feathers edged with brownish. Bill brownish white marked with red in spots; pouch dark greenish black: bare space in front of the eye bluish; tail consists of twenty-two feathers. The immature bird has the head and neck brownish gray.

Length, 50 ; Wing, 20: Tarsus, 2.90; Bill, I 1.

This species is abundant in Florida, breeding in numbers in some localities. The eggs are three to five, of a bluish white color, covered with a chalky deposit.

Habitat: "Atlantic coast of tropical and sub-tropical America, north on the Atlantic coast to North Carolina ; accidental in Illinois." (A.o.c.) 


\section{Famila FREGA'TID.E. MaN-o'-War Birds.}

\section{GENus FREGATA Curier.}

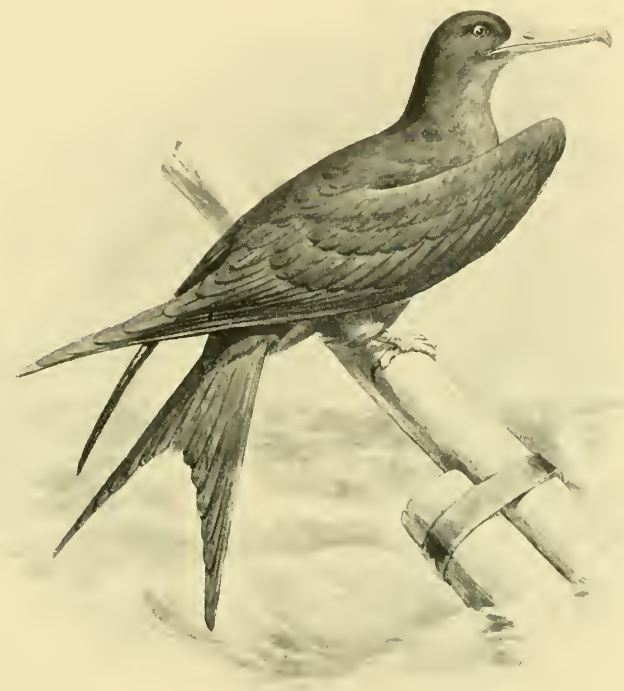

FREGATA AQUILA (Linn.).

\section{Man $=0^{\prime}=$ War Bird.}

Adult male: Entire plumage brownish black, showing a greenish reflection on the head, and purplish upon the back; tail forked and composed of twelve feathers: gular sac pale orange: iris brown.

Adult female: Differs from the male by having a white patch on the breast. which extends along the sides of the neck and around it near the middle.

Length, 43: Wing, 25; Tail, 19: Tarsus, 1 : Bill, 6.

This species is common on the Florida coast. It is possible that it may nest on some of the keys : but I know of no actual record of its breeding in the United States. It breeds commonly in the Bahama Islands, where I have often found its nest. The female lays one white egg.

Ranges along the tropical and sub-tropical coast of America, and an occasional straggler has been recorded as far north as Nora Scotia. 


\author{
ORIEER ANSERES. \\ L.Minelirostral Swiminer. \\ FAnily ANATID.E. Ducks, Geese, ANI SWANs. \\ Subfamly MERGINA. Mergansers.
}

Fish=eating ducks having narrow bills with tooth=like serrations on edges.

\title{
GENus MERGANSER BRISSON.
}

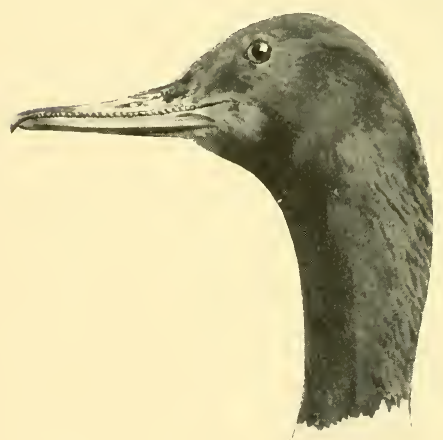

Merganser americanus (male).

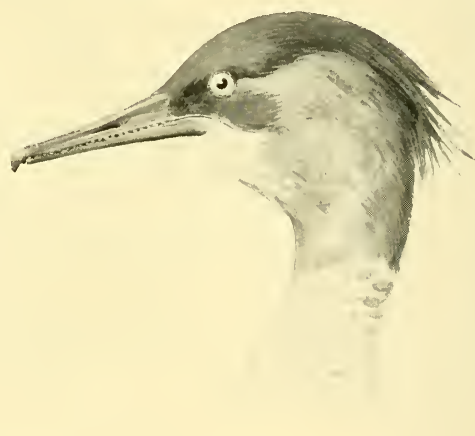

Merganser americanus (female).

\section{MERGANSER AMERICANUS (Cass.). American Merganser.}

Adult male: Bill red, long and narrow, with tooth-like serrations: head and neck greenish black: under parts creamy white tinged with salmon color; tail gray; feet red.

Length, 26.50; Wing, 11 : Tarsus, 2 ; Bill. 2.10.

Adnlt female: Lpper throat white; breast and head rufous brown ; belly white : speculum white: feet orange.

Length, 24.50; Wing, (0.7.5; Tarsus, r.90; Bill, 2.

The distance from the nostril to the tjp of the bill is less than 1.50 inches in this species, and the female may be distinguished from the next species, viz., Red-breasted Merganser, by this 
character, as the Red-breasted Merganser has a distance from the nostril to the tip of the bill of more than $\mathbf{r} .50$ inches.

This species ranges throughout North America and is not uncommon on the Atlantic coast from Maine to Georgia. Occasionally a specimen wanders as far south as Florida, although it is not common in that State. I have on one occasion killed a specimen near the head of Indian River. The nest is composed of a little grass or leaves on a ledge or occasionally in a hole in a tree.

The eggs are from seven to ten, of a pale yellow buff color.

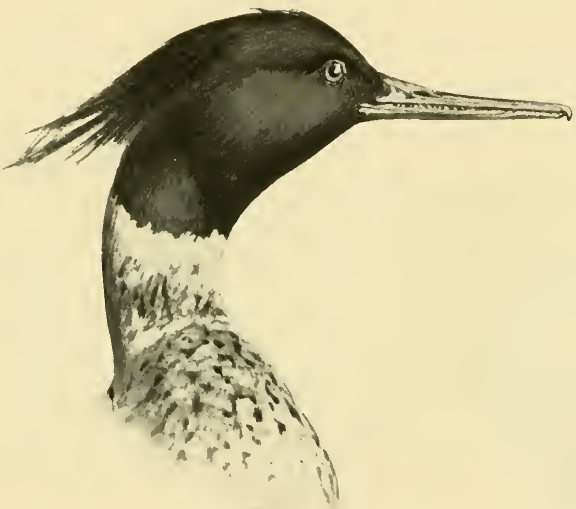

Merganser serrator (male.)

\section{MERGANSER SERRATOR (Iimm.).}

Red=breasted Merganser.

Adult male: Head and throat black tinged with greenish: a white ring around the neck not always well marked; breast rufous streaked with black; lower breast and belly white: the sides and rump delicately pencilled with black. I)istance from nostril to tip of bill more than 1.50 .

Length, 23; WVing, 9; Tarsus, r.90: Bill, 2.30.

Female and young male: Head brownish: throat pale buff: back gray: under parts of the body are white and speculum is white.

Length, 21 ; Wing, 8.80; Tarsus. 1.90 ; Bill, 2.50.

Inhabits the northern part of the Northern IIemisphere, ranging in winter southward throughout the United states to Cuba. It is a common bird on 
the Atlantic coast and is the common "Shelldrake" of Florida: some winters they are abundant. This and the Hooded Merganser are the two species which are common in Florida in winter.

The female of this species may be easily distinguished from the American Merganser by the difference in the measurement of the bill: the bird is also somewhat smaller. The distance from the nostril to the tip of the bill in this species measures more than I.50 inches.

It breeds from New Brunswick northward, the eggs being pale buff in color and usually from eight to twelve in number.

\section{Gext: LOPHODYTES Reich. \\ LOPHODYTES CUCULLATUS (Lim.). Hooded Merganser.}

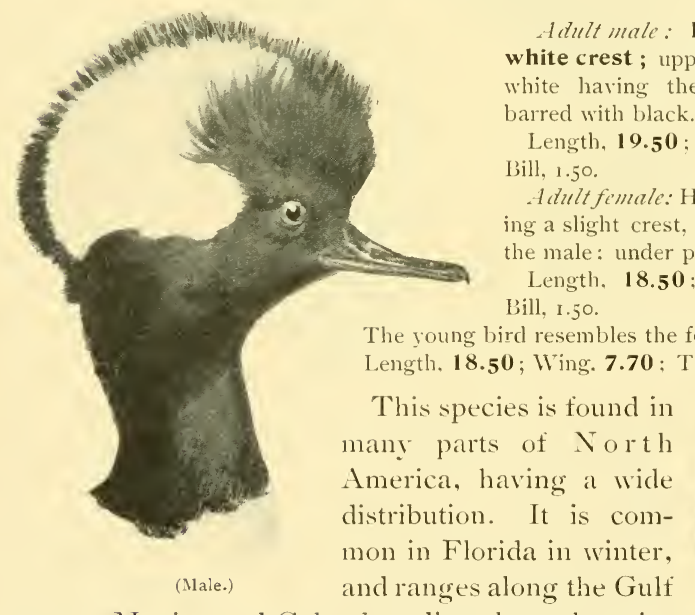
coast to Mexico and Cuba, breeding throughout its range. The eggs are usually deposited in a hollow tree near the water : they are white, sometimes buffy white in color, and usually number from seren to ten. It has a peculiar note, somewhat resembling that of the Scaup Duck, but sharper. 
Subramily ANATINA. River Ducks.

\section{Ducks having hind toe without membranous lobe or flap.}

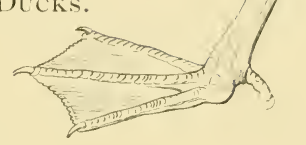

\section{Genus ANAS Linn.}

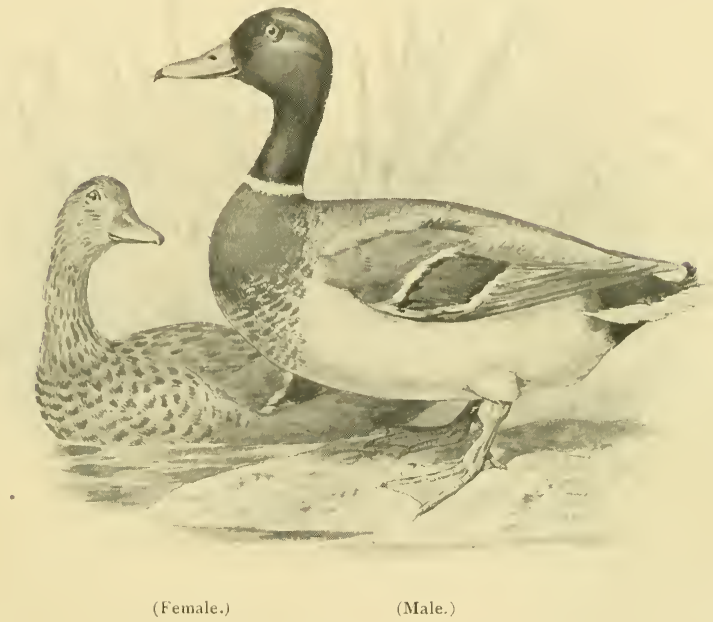

\section{ANAS BOSCHAS. Limn. \\ Mallard.}

Adult male: Head and neck dark green with a white ring on the neck; under parts whitish or ashy white: breast is rich chestnut brown; under tail coverts black: upper tail coverts are also black with central feathers elongated and curved upwards: speculum purple bordered with black and white; feet orange red.

Adult female: Speculum purple bordered with black and white ; head brownish buff : belly buffy brown, usually mottled : feet are red.

Length, 23 : Wing, 10.50: Bill, 2.20.

This species inhabits the northern part of the Northern Hemisphere. It breeds far northward and ranges in winter to the West Indies and Central America and is not uncommon in Northern Florida. I have killed a num- 
ber of specimens near Cape Canaveral. The eggs are greenish white and usually from seven to ten in number.

The Mallard is known to cross with various species, some sixty or serenty hybrids having been recorded; the most common crosses being with the Pintail, Black Duck, and Widgeon. The female may always be distinguished from the Black Duck by the white border of the speculum.

The male says, "Drake, drake, drake, drake," several times in a husk voice and also ". Shwipe," low and husky like a I3lack Duck. The female "quacks." Drakes rarely "quack"; in most species of ducks it is usually the female.

\section{ANAS OBSCURA Gmel.}

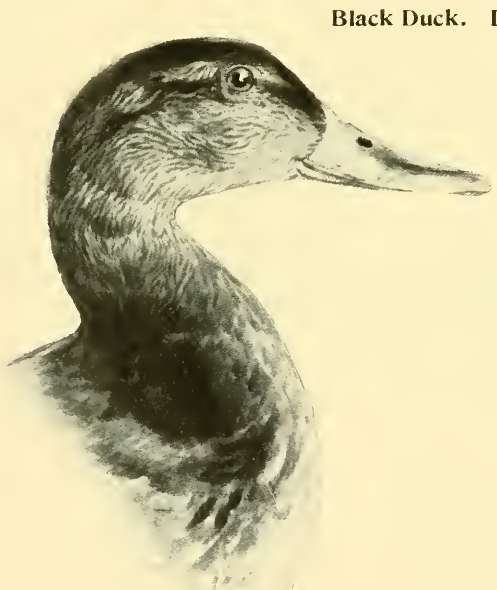

in a husky voice: the female " quacks."

Head and neck pale brown, finely dotted and streaked with dark brown: top of the head darker than the cheeks: general plumage dark brown; feathers edged with pale buff; speculum purple edged with black; bill yellowish green with dark nail, no black at the base; feet orange red with dusky webs; the color of the feet varies.

Length, 21: Wing, 10.75: Bill, 2.10: Tarsus, 1.75 .

This species may always be easily distinguished from the female of the Mallard by the absence of the white stripe on the speculum. It is pretty well distributed over North America and breeds from New England northward.

The male says: "Drake, drake, drake, drake," and also "Shwipe,"

It ranges in winter to Cuba and the Antilles and is common in Florida. where it may easily be distinguished from the local species by the streaked cheeks and throat. It is also darker in color than the Florida Black Duck.

The eggs are nine to twelve and are pale greenish white. 


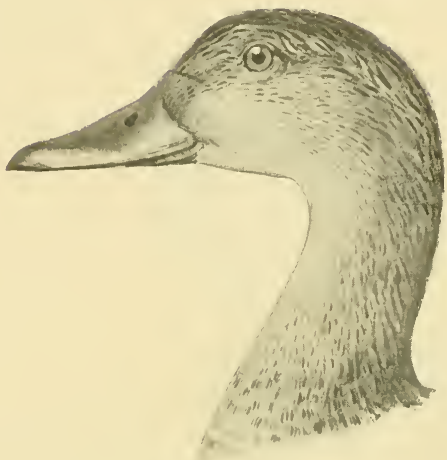

ANAS FULVIGULA Ridgziay.

Florida Black Duck. Florida Dusky Duck.

Adult male: Upper mandible yellowish olive, nail and spot at base of mandible black : sometimes mixed with dull orange; under mandible yellowish olive, dusky at tip; legs and toes pale orange with the webs red; iris brown.

Adult female: Legs and toes dull Indian red; webs mottled brownish and flesh color; upper mandible yellowish olive showing a brownish stripe on the middle and the nail and a spot at the base black; under mandible pale orange yellow.

General appearance of the Northern Black Duck and lighter in color and having the throat and cheeks almost without streaks and very pale buff in color.

Length, 20; Wing, 10.20; Bill, 2; Tarsus, r.70.

This is a resident species in Florida, where it is becoming rather rare in many localities where it was once common. It nests in the marshes, the eggs being pale greenish in color. I have found two nests of this species on the Banana River. Eggs are usually from eight to ten in number, but I have heard of fourteen eggs being taken in a nest. The note resembles that of the Black Duck. 


\section{Subgenus CHAULELASMUS Bonaparte.}

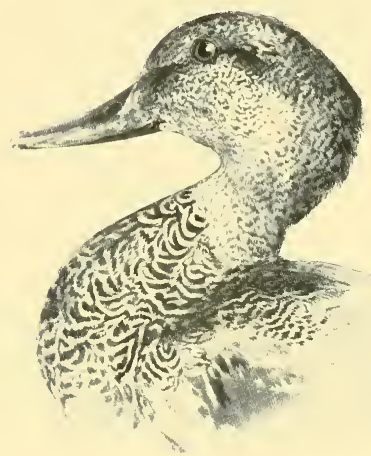

(Male.)

\section{ANAS STREPERA Linn.}

Gadwall.

Adult male: Head brownish finely streaked with black and dark brown; sides of the head pale brown mottled with black; neck and breast mottled (black and white), the feathers being black having a central white mark; under parts white (sometimes grayish white). Under tail coverts are black and upper tail coverts and rump are black: speculum gray and white ; the lesser wing coverts chestnut; bill black; feet orange.

Length, 19.50 ; Wing, 10; Bill, 1.60.

Adult female': Somewhat resembles the male but has the under wing coverts pure white and usually little or no chestnut on the lesser wing coverts.

Length, 19; WVing, ro; Bill, 1.55.

Range: North America, breeding usually in the interior in the northern part. It is common in Florida in winter where it is known as Creek Duck. The eggs are usually from nine to twelve and buffy white in color. The note of the male somewhat resembles the call of a deer or perhaps the squeak of a door: the female "quacks" softly. 


\section{Subgenus MARECA Stephens.}

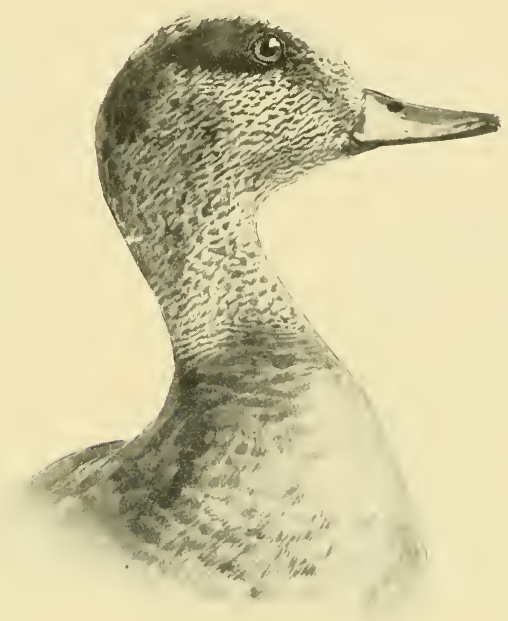

(Male.)

\section{ANAS AMERICANA Gmel.}

\section{Baldpate. American Widgeon.}

Adult male: Head speckled black and white; top of the head white; a broad stripe of greenish back of the eye to the occiput: chin blackish ; upper breast pale ashy lilac or vinaceous : rest of under parts pure white: crissum and under tail coverts black: back ashy vinaceous finely pencilled with black; a broad patch of white on the wing: most of the secondaries have the outer web black edged with white : the inner webs are grayish towards the tip ; speculum black and green.

Adult female: Head and throat whitish, streaked and mottled with black; back grayish brown; tertials dusky edged with whitish.

Length, 19; Wing. 10.50: Tarsus, 1.60: Bill, 1.40.

This species ranges nearly throughout North America but does not breed on the Atlantic coast as far as known. It is very common in winter in Florida occurring along the Gulf to Central America and Northern South 
America and the West Indies. The eggs are pale brownish white from eight to twelve in number.

The European Widgeon (. Inas penclope), which occasionally wanders to our shores has the head cinnamon, speckled with brown while the American form has the head grayish speckled with dusky. The note of the male is three soft whistles " Do mi do" of the scale; the female ". quacks."

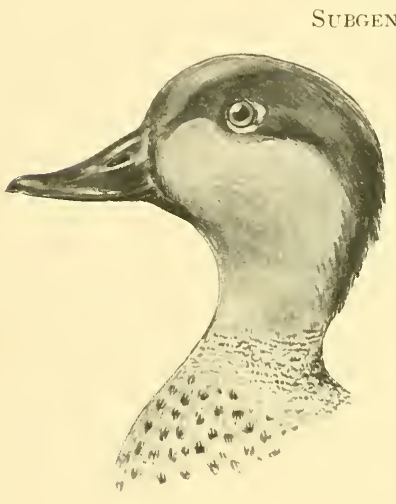

(Male.)

\section{NETTION KAUP.}

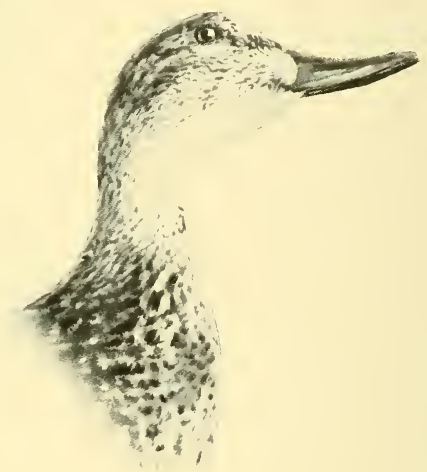

(Female.)

\section{ANAS CAROLINENSIS Gmel. Green=winged Teal.}

Head and neck chestnut brown; a patch of green behind the eye extending to the nape. Feathers are somewhat elongated forming a small crest: sides and back pale. marked with narrow fine lines of black; under parts white, shading into pale brown or buff on the breast, which is also spotted with black; speculum green bordered with black and chestnut.

Adult female: Has top of the head brownish margined with reddish brown: throat and sicle of the neck white spotted with black; breast brownish with black spots; rest of under parts white, sometimes showing black spots on the under tail coverts.

Length, 14.50; WVing, 7.20: Tarsus, 1.25; Bill, I.50.

This species ranges throughout North America breeding north of the United States. Ranges south in winter to the West Indies, the Gulf of Mexico and Central America; common in Florida in winter. The eggs are pale brownish white and usually number from seven to twelve.

The male whistles sharp and low, and the female "quacks." 


\section{SUlignus QUERQUEDULA STEPhENS.}

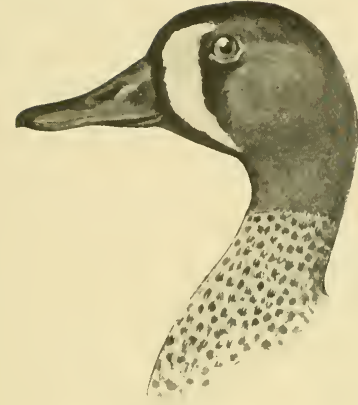

(Male.)

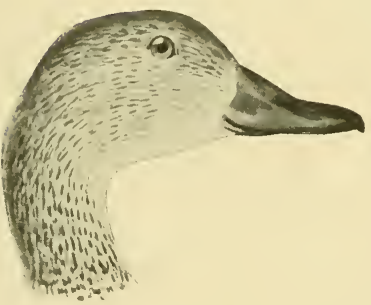

ANAS DISCORS limn.

\section{Blue=winged Teal.}

Adult male: Head gray with purplish gloss, darkest on top: a white patch resembling a crescent in front of the eye; wing coverts and some of the scapulars pale grayish blue forming a grayish blue patch on the wing; speculum rich green: under parts purplish gray spotted on the breast with black; the flanks are narrowly barred with black. The bill is black, the feet yellow.

Adult female: Showing a blue patch on wing, which distinguishes it from other Teals, except the female of Inas cyanoptera, but the color of the head will always distinguish it from that species.

Length, 16 ; Wing, 7.25 ; Tarsus, 1.25; Bill, 1.60.

(Female.

Ranges throughout Eastern North America breeding chiefly north of the United States. In winter it is common in Florida and its range extends to the West Indies and Northern South America. The eggs are pale buff usually from eight to twelve in number. The male whistles and the female " quacks."

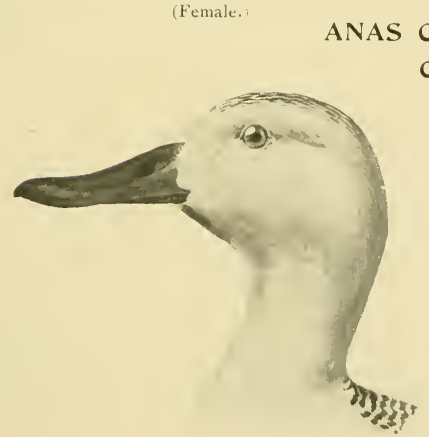

\section{CYANOPTERA I'icill. Cinnamon Teal.}

Idult male: Head, neck, and upper parts chest= nut brown, the crown somewhat darker than the sides of the head: under parts brownish showing dusky on the belly : rump olive brown, feathers becoming lighter on the edges: wing coverts blue gray, similar to the Blue-winged Teal; speculum green; the general coloration of the wing being similar to the Blue-winged Teal, but the coloration of the body is so different that it should never be confounded with that species.

tdult fimale: Resembles the female of the Bluewinged Teal although larger; the under parts show 
a trace of the chestnut marking of the male and the upper throat and chin are more speckled, otherwise apparently quite similar to Anas discors.

Length, 16; Wing. 7.50; Bill, 1.75 ; Tarsus. 1.30.

This is a species which is usually confined to Western North America, only occasionally reaching the Atlantic Coast in the Southeastern States. It has been recorded from Florida, but I have never seen an example from that State, although it is given as quite common by several authors. It extends to Southern South America in its range; does not breed on the east coast.

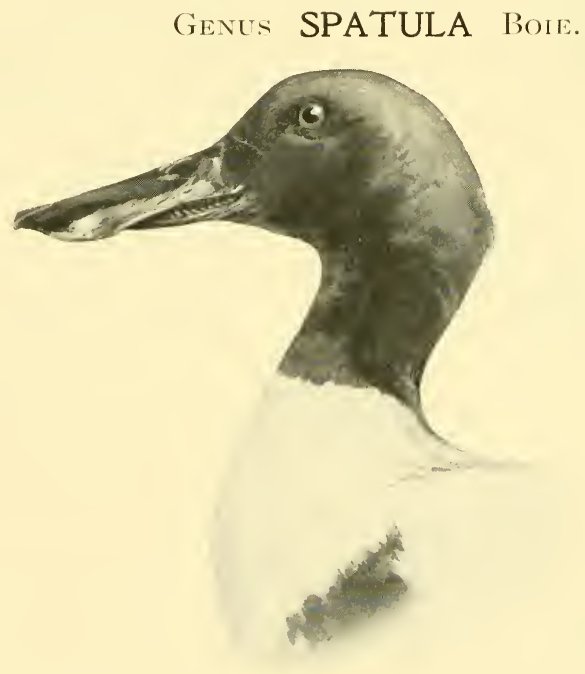

(Male.)

\section{SPATULA CLYPEATA (Linn.). Shoveller.}

Idult male: Bill very much broadened; head and neck dark green: breast pure white shading into purplish chestnut on the belly; wing coverts blue; speculum green edged with white; feet orange red.

Length, .20; Wing, 9.50: Bill, 2.70: Tarsus, I.50. 
Adult female: Head and neck mottled and streaked with pale brown and dark brown or black; under parts brownish, mottled and spotted with fuscous, scarcely showing on the middle of the belly ; speculum and wing coverts as in the male.

Length, 19.50; Wing, 9.50; Bill, 2.60; Tarsus, 1.50.

The immature male is often intermediate in plumage between the adult male and female, but the speculum shows but little green and the wing coverts are slaty gray. The head is often very much mottled when changing to adult plumage.

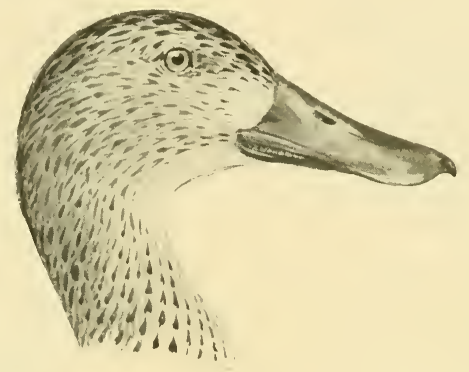

(Female.)

This species ranges throughout the Northern Hemisphere, commonly in the interior. It breeds from Minnesota northward as a rule: there is no record of its breeding in the Atlantic States.

Ranges in winter to South America, being one of the common species in Florida during the winter months. The eggs are pale buff white, usually from six to ten in number. The note of the male is a gutteral short ". Thuck thuck"; the female " quacks."

\section{Genus DAFILA Stephexs.}

\section{DAFILA ACUTA (Limn.).}

Pintail. Sprigtail.

Adult male: Bill black having the edges lead color; head and neck dark rufous brown sometimes showing a faint gloss of green on the feathers; sides of the neck showing a stripe of white and a stripe of black extending down the back of the neck: under parts white showing faint wavy fine lines of dusky on the sides: crissum black edged with white; central tail feathers very much elongated in the male; feet lead color.

Length, .28; Wing, 9.50: Tail, 7 : Bill. 2. 
Adult female: Tail feathers not so much elongated as in the male; crown and sides of the head streaked with dusky and pale brown; breast spotted with dark brown or black; under parts white; abdomen and sides showing faint lines of dusky; under wing coverts fuscous edged with white axillars marked with black; speculum grayish brown edged with white. The immature male shows considerable variation in plumage, the under parts being usually more streaked or spotted than the adult female, which it otherwise somewhat resembles.

Length, .2.2 ; Wing, 9.25; Tail, 3.50: Bill, 2.

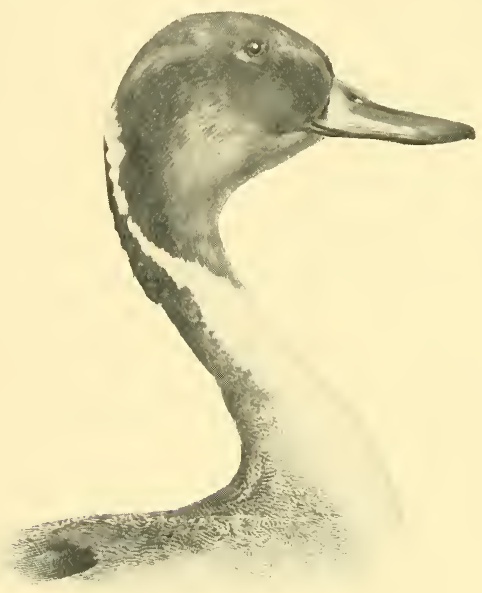

Dafila acuta (male).

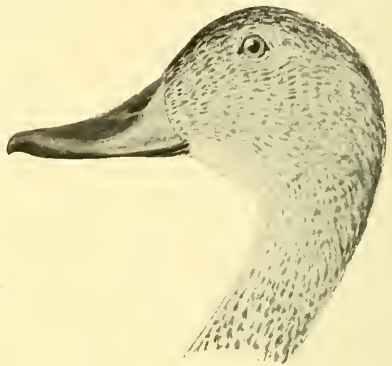

(Female.)

Ranges throughout the Northern Hemisphere breeding from Illinois northward; apparently does not breed on the Atlantic Coast, but is common in winter from Virginia and the Carolinas southward to the West Indies and Central America. It is one of the common ducks in Florida.

Eggs are usually from seven to twelve and are bluish white in color. The female Pintail may always be recognized by the pointed middle tail feathers and the blackish under wing coverts.

The male whistles and the female "quacks." 


\section{Gents AIX Bone.}
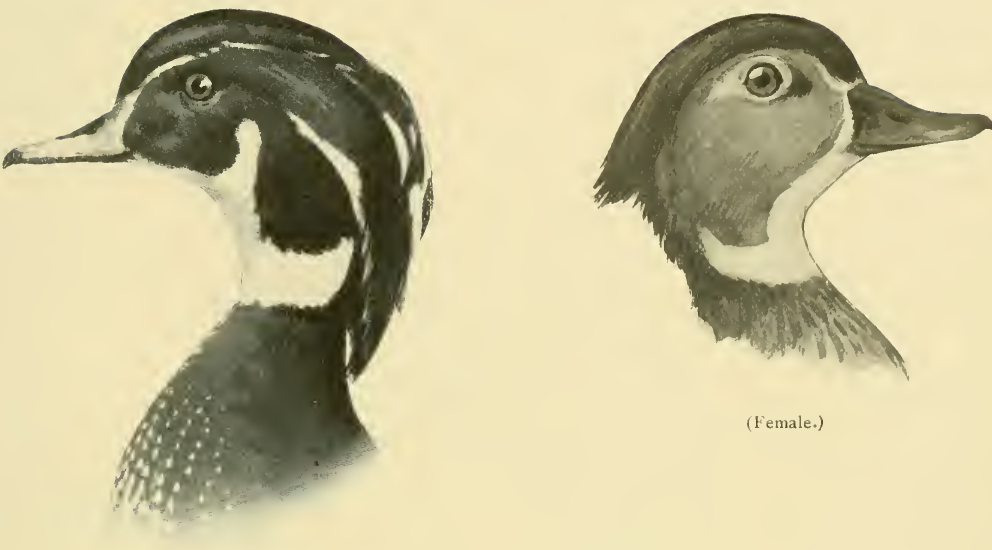

(Female.)

(Male.)

\section{AIX SPONSA (Limn.).} Wood Duck.

Adult male: Bill red marked with rose-white and a black stripe on the middle of the upper mandible and tip; under mandible black; head with decided crest, which shows white, metallic green, and purple; a narrow superciliary line from the bill to the occiput and another stripe of white behind the eye extending to the nape; chin and throat white, extending upwards in a streak on sides of head, back of eye; a stripe passing upwards on the side of the head; sides and front of the lower neck and under breast purplish chestnut dotted with white spots; under parts white, sides sometimes grayish showing faint pencilling of dusky lines; upper parts showing bronze green and purple; speculum bluish green edged with black and white.

Length, 18..j(); Wing, 9.50; Bill, 1.40.

Adult female: Crest small but the feathers somewhat lengthened; head and neck grayish, whitening on the chin and front of the eyes; front of the neck and breast pale brown mottled with grayish; the breast showing numerous brown spots which fade away on the lower breast; belly white.

Length, 18; Wing: 9.30; Bill, 1.35.

This species ranges from the Gulf northward to Hudson's Bay, breeding nearly throughout its range: it is common in the interior of Florida and has been taken in Cuba and Jamaica. The eggs are pale brownish white and usually number from seven to fourteen. It nests in a hole in a tree. 


\section{Subfanly FUliguline. Bay and Sea Ducks.}

Ducks having flap or membranous lobe on hind toe.

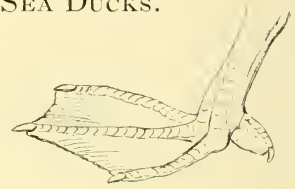

\section{Genus AYTHYA Boie.}

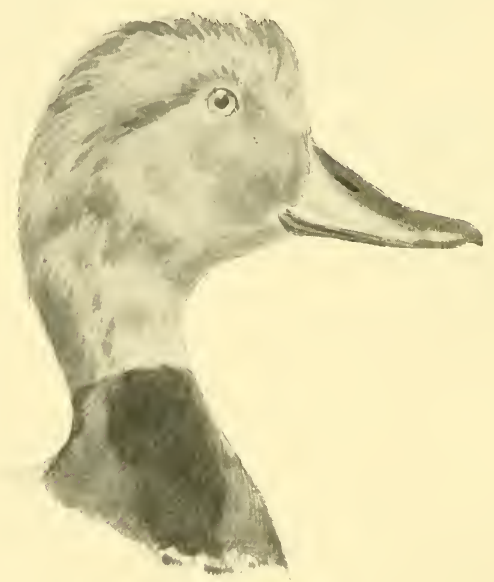

AYTHYA AMERICANA (Eyt.).

Red=head Duck.

Adult male: Head and neck brownish chestnut; lower neck and upper breast blackish; back apparently grayish being pencilled with wavy lines of black; speculum grayish; upper feathers edged with black, the rest narrowly tipped with white.

Length, 21 : IVing, S.40; Tarsus, r.6o; Bill, 2.20.

Adult female: Bill bluish showing an indistinct bar near the end; head and neck reddish brown, palest on the sides of the head, becoming asliy on the sides of the head; upper throat white; breast and sides brownish; belly white; under tail coverts and lower belly sometimes washed with pale brownish.

Length, 20.50; Wing, 8.30; Tarsus, r.6o; Bill, 2.20.

This is rather a Western species, as it breeds very rarely on the Atlantic coast of the United States. It is common in the West breeding from 
Minnesota northward. It ranges in winter south to the Northern West Indies and occasionally occurs in Florida, although not in any great numbers. It is a very abundant species from Carolina to Virginia during the winter, in suitable localities. The Red-head may easily be distinguished from the Canvas-back by the shape of the bill. The forehead arches abruptly from the bill and does not follow the line of the bill, as in the Canvas-back.

The female Red-head closely resembles the female of the Ring-necked Duck but is larger. It does not breed on the Atlantic coast.*

\section{AYTHYA VALLISNERIA (Wils.). Canvas=back Duck.}

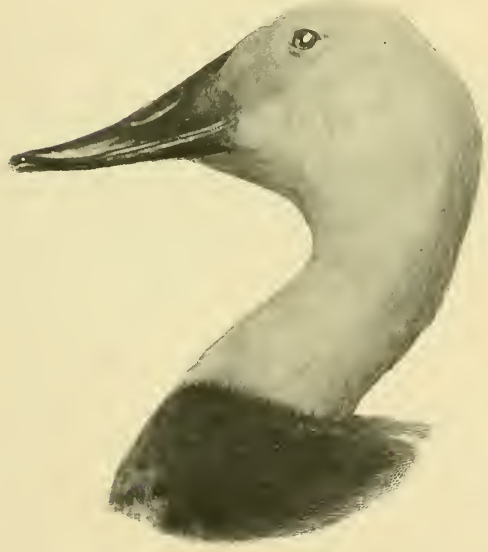

Adult male: Head and neck rufous brown becoming dusky on the crown and chin; the breast and upper portion of the back blackish; rest of upper parts and wing coverts showing fine wavy lines of black, general appearance being grayish; belly white, the lower portion faintly lined with dusky. Sides white, showing the delicate lines as on the back, but very much fainter and sometimes wanting.

Adult female: Head and neck cinnamon brown, paler on the throat; belly white or grayish white.

Length, 20 to 22 ; Wing, 8.75 to 9.25 ; Bill, .75 to .So; Tarsus, $\mathbf{1 . 7 0 .}$

The peculiar formation of the bill will always distinguish this species from the Red-head, which it somewhat resembles.

Occurs throughout North America and is more common in the West. Breeds from the Northwestern States northward to Alaska. It ranges in winter south to Cuba and Jamaica, although it is only a straggler and is by no means common in Florida. I have occasionally killed specimens as far south as Cape Canaveral.

This species is common off the coast of Virginia and Chesapeake Bay during the winter months. It does not breed on the Atlantic coast.

\footnotetext{
* A single instance is on record of a pair being found breeding near Calais, Maine.
} 


\section{Subgenus FULVIGULA Stephens.}
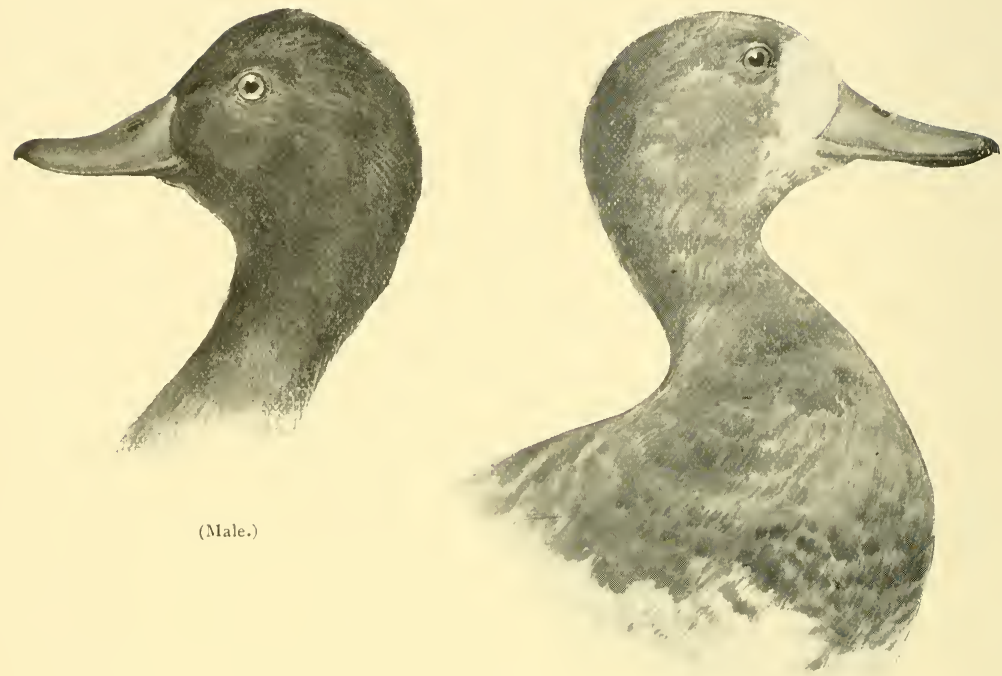

(Male.)

Female.

\section{AYTHYA MARILA NEARCTICA Stejn. American Scaup Duck.}

Adult male: Head and neck and upper breast black showing greenish reflections; back grayish white delicately lined with fine wavy lines of black, giving it a grayish appearance; speculum white; under parts white, the lower belly showing grayish tinge.

Length, 19: Wing, 8.50: Tarsus, 1.50; Bill, 2.

Adult female: Patch at the base of the bill white or grayish white, rest of the head and neck, breast and upper back brownish; belly white: speculum white.

Length, 17.75; IVing, 8.25: Tarsus, 1.30: Bill, 1.60.

Species ranges throughout North America, breeding north of the United States. It ranges in winter south to the Bahama Islands, and on the Atlantic coast south to Florida, although it is not nearly as abundant in Southern waters as A. m. affinis, to which it is very closely allied. There are, ap- 
parently. no constant characters (with the possible exception of size) by which it may be separated from that species: the head, as a rule, shows greenish reflections, while the Lesser Scaup Duck generally has the head glossed with purplish, but these characters cannot be always depended upon and the main difference is one of size.

The eggs are described as being pale olive buff and number from six to ten. It nests on the ground, as is common with the Sea Ducks.

The only duck that this common bird is likely to be confounded with is the Ring-neck, and it can always be distinguished at a glance from that species by the white band on the wing (speculum), which is always gray in the Ring-neck.

\section{AYTHYA AFFINIS (Eyt.). \\ Lesser Scaup Duck.}

Wale: Resembles the male of the preceding species but is somewhat smaller in size; the head generally shows a faint gloss of purplish, while the Greater Scaup Duck shows a greenish tinge on the head.

Length, I7; Wing, 8.10; Tarsus, I.50; Bill, r.So.

The female resembles the female of the preceding species but varies in being smaller; the speculum of both the male and female is white, and this duck may always be distinguished from the Ring-neck by this character.

Length, 16.50; Wing, 7.70; Tarsus, I.25; Bill, I.50.

This bird ranges throughout North America, breeding north of the United States, and occurs in winter south to Guatemala and West Indies. It is the most common species in Florida, being one of the first to arrive and among the last to leave the State. I have seen small flocks of them in the rivers as late as the first of May. The note of this and the Greater Scaup Duck is a peculiar sound, difficult to describe but rather easy to imitate. It somewhat resembles the sound made by rubbing the finger quickly and lightly over a roll-top desk.

\section{AYTHYA COLLARIS (Donoz'). Ring=necked Duck.}

Adult male: Head and neck, upper breast and upper back black, showing faint bluish reflections when held in the light. In the breeding season the male has an orange chestnut collar which is usually lacking later in the season; belly white with the lower belly finely lined 
with black; back and scapulars dusky : speculum gray; bill dusky, showing a faint bluish gray band near the end.

Adult female: Head brownish, the sides mixed with grayish brown, widening on the cheeks and base of the bill; belly whitish, becoming grayish on the lower portion; bill as in the male.

Length, I 7 ; Wing, s; Bill, 2.
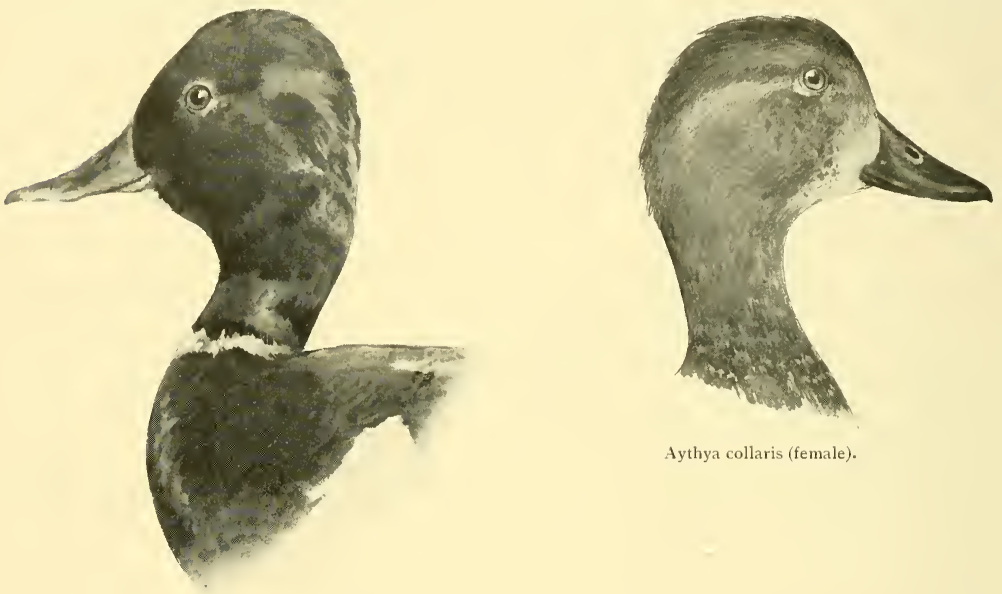

Aythya collaris (female).

Aythya collaris (male).

Species ranges throughout North America breeding north of the United States. It ranges south in winter to Guatemala and the West Indies. It is common in Florida, generally preferring fresh or brackish water to the ocean.

The female of this species resembles the female Red-head, but is easily distinguished from that species by its smaller size. This species may be distinguished in any plumage from the Scaup Ducks by its gray speculum. The note somewhat resembles that of the Scaup Duck. In winter the collar of the male is usually absent or but slightly indicated. This species does not breed on the Atlantic coast. 


\section{Genes GLAUCIONETTA StejN.}

\section{GLAUCIONETTA CLANGULA AMERICANA ( Bonap.). American Golden Eye. Whistler.}

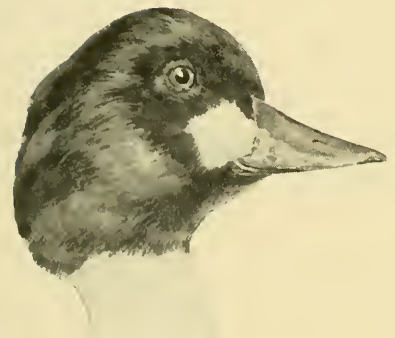

Adult male: Head and neck glossy green; a patch of white in front of the eye: back black; under parts white : speculum white: lining of the wings dusky.

Length, 19.50: Wing, 9.10: Tarsus, 1.60: Bill, 1.90.

Adult female: Head brown showing no white in front of the eye: upper parts dark brown inclining to dusky but not black: under parts white, sometimes washed with gray on the sides and lower neck.

Length, I6.50: Wing, 8.25: Tarsus, I.40; Bill, г.6о.

This species ranges generally throughout North America, breeding from ilaine to the British Provinces northward. It winters from New England southward and stragglers have (Male.) been secured as far south as Barbadoes and Cuba. It is not a common bird in Florida, although the species occur more or less regularly on the Indian River during the winter months. Its nest is placed in a tree or hollow stump. The eggs are usually from eight to ten in number and dull bluish white.

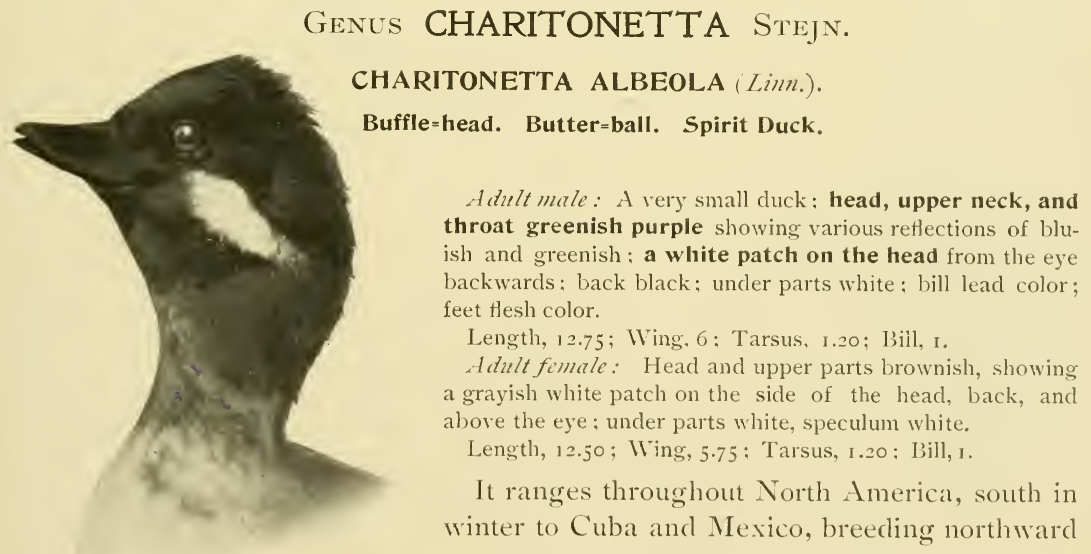


from Maine to Alaska. The nest is described as being built in a stump or tree. The eggs are a pale buff usually from eight to twelve in number.

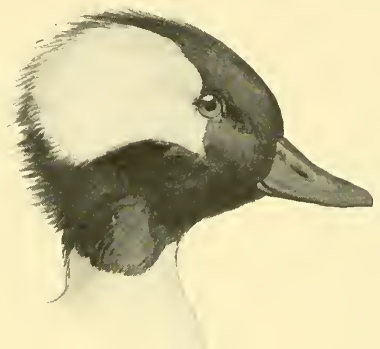

Charitonetta albeola (male).

\section{Genus CLANGULA Leach.}

\section{CLANGULA HYEMALIS (Limn.). Old Squaw. Old Wife. South Southerly.}

Adult male in winter: Central,tail feathers black, much elongated; outer tail feathers white; top of the head and back of the neck to back white; a patch of grayish on the sides of the head including the eye, which is succeeded by a patch of black on the sides of the neck,

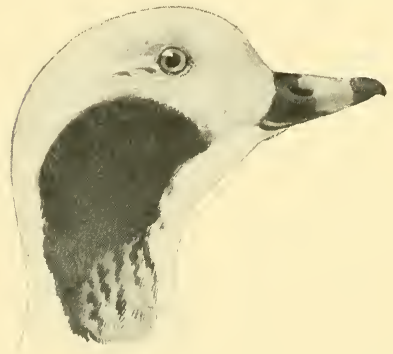

(Male, winter plumage.) bordered on the lower throat by an indication of brown : throat and upper breast pure white: breast and upper belly black, the black continuing over the back in a band: lower belly and under tail coverts white; wing coverts black; quills brown: a pale yellowish band across the end of the bill.

Male in summer: Front of the head white; rest of head, neck, breast, and upper belly smoky black.

Adult female in winter: Head dull white on the crown and a patch on the side of the back of the head smoky black or brownish black: upper parts fuscous ; breast grayish: belly white: tail feathers pointed but not elongated as in the male.

Length (including tail), 21; Wing, S.05: Bill, 1. 
It ranges throughout the Northern Hemisphere: in North America south to the Potomac and the Ohio; it breeds far northward.

(A.O.U.)

The eggs are described as being pale bluish and usually from six to twelve in number.

This is one of our most common ducks on the New England coast in fall and winter. It ranges south as far as Florida, but is not common, although I have occasionally taken specimens on the Banana River. In the winter of $1894-5$ there were a number of these birds at Lake Worth.

\section{Genus OIDEMIA Fleming.}

Subgenus OIDEMIA.

OIDEMIA AMERICANA Sw. \& Rich. American Scoter. Black Coot.

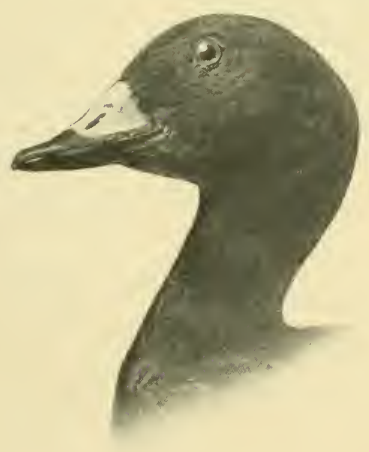

(Male.)

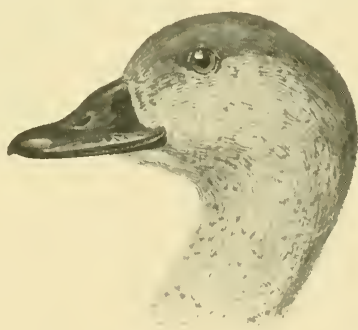

(Female.)

Adult male: General plumage entirely black; bill black, the upper mandible being yellowish orange at the base. Feathers on the bill more than one half an inch from the nostril; no white on the wing.

Adult female: Brownish or sooty brown: paler on the under parts, becoming grayish white on the belly: sides of the head whitish. The female is smaller than the male.

Length, 19: Wing, 9.10; Tarsus, 1.65; Bill, 1.So.

Species breeds from Labrador northward; the eggs being described as pale brown or dull whitish brown and from six to ten in number. It ranges 
in winter south to Florida and California. I have killed specimens on the Indian River and saw it at Lake Worth, although it cannot be considered as a common bird in Florida every year, probably occurring there in numbers only when the northern winters are unusually severe.

Subgenus MELANITTA Boie.
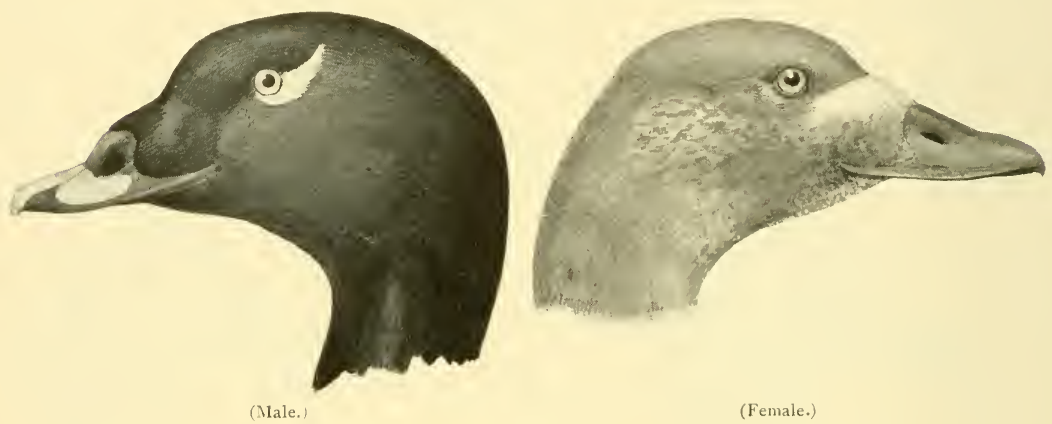

OIDEMIA DEGLANDI Bonat.

White=winged Scoter. White=winged coot.

Adult male: (ieneral plumage black; upper mandible orange. blackish at the base: a white spot under the eye and a broad patch of white on the wing; feathers on the bill less than one half inch from the nostril.

Adult female: Is grayish brown, showing a wash of grayish white at the base of the biil and behind the ears: the speculum is white, which is a distinguishing character of this species.

Length, 21; Wing, 11.15: Tarsus, 2: Bill (culmen), 1.75; side measure, 2.75.

It breeds from Labrador northward, ranging in winter South to Floricla and California. I found it on the Banana River and Lake Worth during the winter of Is $9+5$.

The eggs are described as being buff or cream color, six to ten in number, the nest being placed on the ground. 


\section{SUBGeNus PELIONETTA KAUP.}

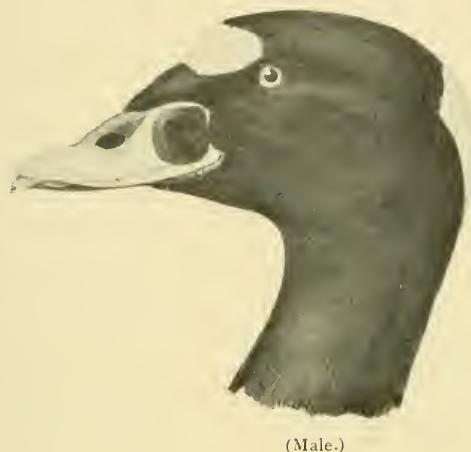

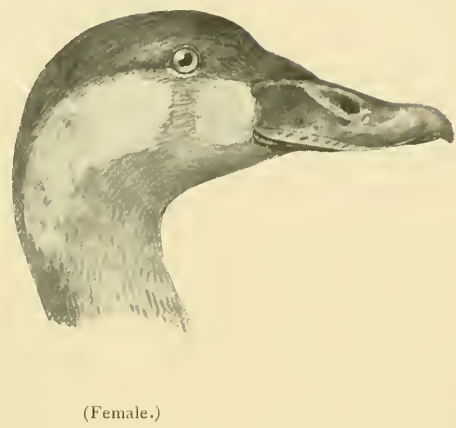

\section{OIDEMIA PERSPICILLATA (Limn.).}

\section{Surf Scoter. Sea Coot.}

Adult male: General plumage black, no white on the wing; head black with a white patch on the forehead and nape: feathers on the bill less than one half inch from the nostril. A peculiar highly colored bill is one of the distinguishing marks of the male of this species, it being orange, yellow, black, and white, the feathers on the top of the bill extending much farther forward than on the sides.

The female and immature brownish, showing a whitish spot at the base of the bill and back of the eyes; the female having the upper parts brownish; under parts ashy gray shading into whitish on the belly.

Length, 20.50; Wing, 9.60; Tarsus, 1.65: Biil (culmen), r.50; side measure, 2.35.

This species may always be distinguished from $O$. amricana by the forward extension of the feathers on the top of the bill and from $O$. alcolandi by the absence of the white wing patch. It ranges along the coast of Northern North America and southward in winter to Florida and has been recorded from Jamaica. In the winter of $1894-5$ it was common about Lake Worth but is usually not numerous in Floricla.

The eggs are described as being buffy or dull white and five to eight in number. 


\section{GeNus ERISIMATURA BONAP.}

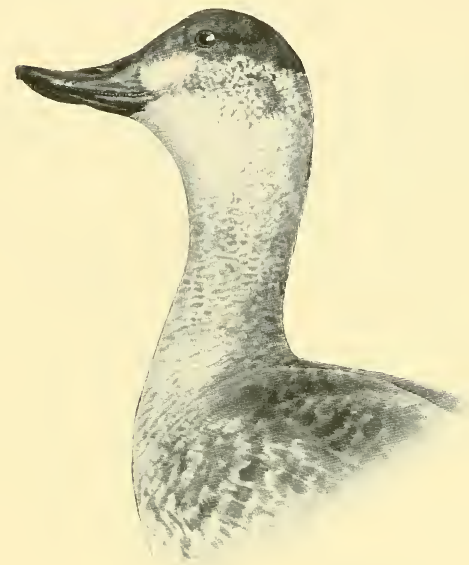

ERISMATURA RUBIDA ( IITis.).

Ruddy Duck.

Idult male: A patch of white on the cheeks and chin; rest of head and general plumage chestnut brown; the under parts silver white; tail feathers pointed and stiff. Male in winter has the back of the head and neck smoky brown; cheeks white; the bill bluish and the feet lead color.

Adult female: The general color of the upper parts is brownish gray; sides of the head and throat whitish. shading into gray on the lower throat and upper breast; under parts silver white, as in the male.

Length, 15.30; Wing, 6: Tarsus, 1.20: Bill, 1.50.

It may easily be distinguished from other species by its small size, chestnut brown color, and stiff pointed tail feathers.

It ranges throughout North America, breeding locally nearly throughout its range. It ranges in winter south to Cuba and Guatemala and Northern South America: it has been recorded from many of the West India Islands.

The eggs are described as six to ten in number, of dull white or buffy white, and the nest is usually built on a marsh but is sometimes deposited on floating vegetable matter. 
SUHFAMIL ANSERINE. GEEsE.

Gexus CHEN Bone.

CHEN HYPERBOREA NIVALIS (Forst.).

Greater Snow Goose.

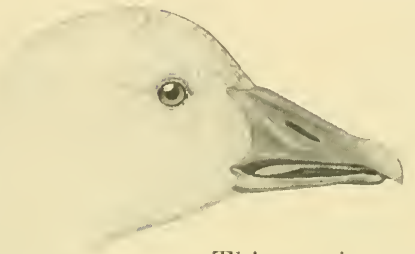

General plumage white: primaries black and primary coverts paie ash. The immature bird has the head, neck, and upper parts mottled gray and white; the rump and tail are white: under parts white.

Length, 34: Wing, 17.40: Bill, 2.50: Tarsus, 3.10.

This species ranges throughout North America. Its breeding place is unknown, but is probably in the far North. It ranges in winter south to the Greater Antilles. It is not a common bird in Florida, but specimens occasionally occur there. It has been taken in Key West and a number of times on the west coast.

\section{CHEN CAERULESCENS (Limn.).}

\section{Blue Goose.}

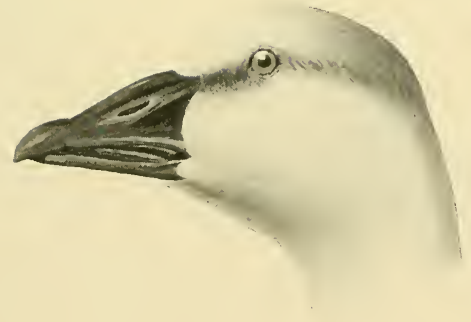

Head and neck white or buff; dusky gray on the neck and back, shading into whitish on the under parts; wings ashy gray, the rump and upper tail coverts grayish white or white: some of the quills and tail feathers dusky, showing white on the edges; primaries are black.

The immature bird of this species has the head and neck grayish brown, shading into dull white on the chin.

Length, 30; Wing, 16: Bill, 2.20: Tarsus. 3.10.

The habits of this species are but little known, and for a long time it was supposed to be the young of the Snow Goose. 
It is now recognized as a species, although comparatively nothing is known of its habits or range. It has been taken in Cuba and I have been told that a specimen was killed on the west coast, but I could not learn the exact locality. I know of no positive record of its occurrence in Florida, but it is probably an accidental winter visitant.

\section{GENUS ANSER BRISSON.}

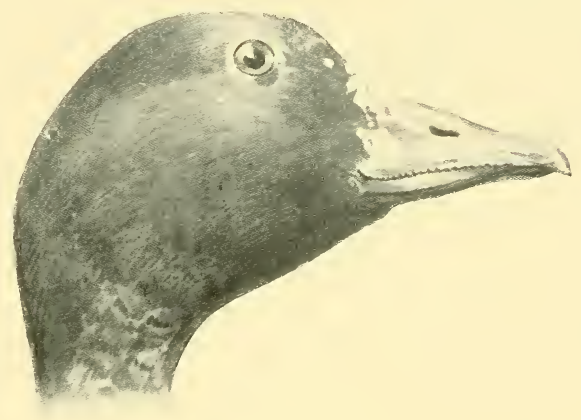

\section{ANSER ALBIFRONS GAMBELI (Hartl.).} American While=fronted Goose.

1dult: Forehead and base of bill white: bill pinkish or reddish or pale white : feet yellow ; the rest of the head brownish: neck grayish brown, shading into dull white in front; under parts whitish, the breast showing black markings; back ashy gray: the feathers anterially edged with brown on the upper part: shafts of quills white.

The immature bird is similar, but shows no white on the base of the bill or black markings on the breast.

Length. 2S; Wing, 16; Bill. 2: Tarsus, 2.90.

This species occurs throughout North America, breeding far North and ranging in winter south to Mexico and Cuba. It is rather rare on the Atlantic coast, but I have been told that specimens have been taken in Northwestern Florida, although I have never seen a bird of this species in Florida myself. Eggs are five to seven, of pale greenish color, sometimes brownish. 


\section{Genus BRANTA Scopol.}

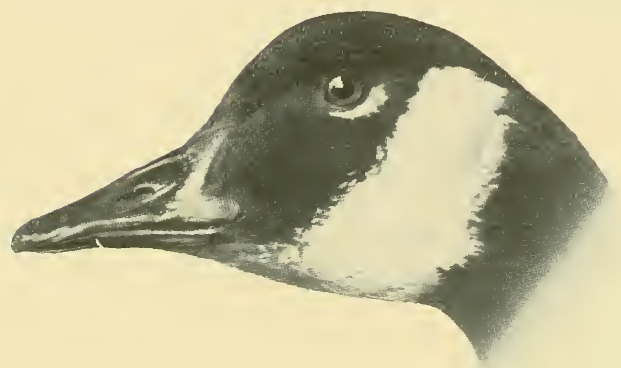

BRANTA CANADENSIS (Linn.).

\section{Canada Goose.}

Adult: Head and neck black: a patch of white on the side of the head behind the eye extending to the chin; back and wings grayish brown; breast and under parts dull grayish white, becoming white on the belly; tail black.

The immature bird is similar, but has the throat and cheeks sometimes mottled.

Length, 40: Wing, 19; Bill, 2.50: Tarsus. 3.20.

The Canada Goose ranges throughout temperate North America, breeding in Northern United States and the British Provinces. It ranges in winter south to Mexico and Jamaica. It occasionally occurs in Florida in winter, as specimens have been killed on the Indian River and also in Northwestern Florida.

The nest, which is composed of sticks and grass lined with feathers, is built in the marshes and on borders of streams; it is claimed that sometimes the nest is placed in a tree. At one time it bred commonly on the Magdalene Islands. The egoss are four or five, usually brownish white. 


\section{BRANTA BERNICLA (Limn.).}

Brant.

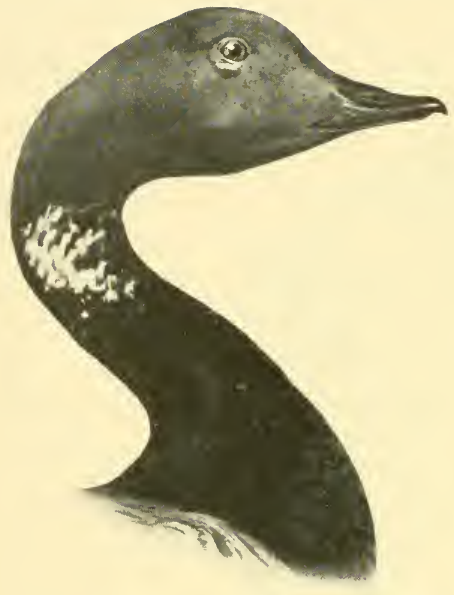

Whole of head. neck, and upper breast black, except a patch on the sides of the neck, which is white and black; back grayish brown; longer tail coverts white: lower breast grayish, shading into white on the belly.

Length. 25; Wing, 13: Tarsus, 2.25; Bill, 1.30.

Ranges from Arctic Circle, where it breeds, southward to Georgia and occasionally to Florida, several having been killed on the Florida coast.

The eggs are described as creamy white in color, four in number. The nest is composed of grass and moss.

SubFaml CYGNIN.E. Swaxs.

\section{Genus OLOR W Agler.}

\section{OLOR COLUMBIANUS (Ord). Whistling Swan.}

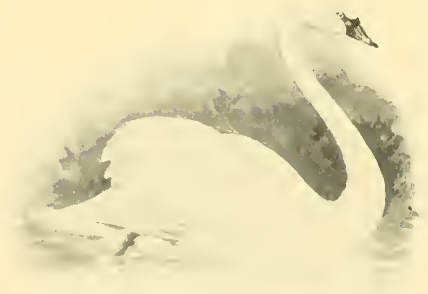

General plumage white; bill and feet black; a small yellow spot at the base of the bill in front of the eye which is not always present: the distance from the front angle of the eye to the back edge of the nostril is more than the distance from the back edge of the nostril to the end of the bill; this is one of the characters by which it may be distinguished from the Trumpeter Swan.

The immature birds are usually ashy gray in color with a brownish wash on the head and upper neck; feet pale y ellowish, sometimes pale flesh color.

Length, 53: Wing, 21.50; Bill, 4; Tarsus, 4.20.

This species ranges throughout most of North America, breeding in the far North. It is common in winter on the Atlantic coast about the Carolinas 
and Virginia, and occasionally wanders as far south as Florida. I know of one or two instances where it has been seen, and a specimen was killed and brought into Jacksonville in the winter of $1894-5$.

\section{ORIDER ODONTOGLOSS.E.}

L.AMELLiRostril Grallatores.

Finim PHCENICOPTERID.E. Flamingoes.

GENes PHCENICOPTERUS LINN.

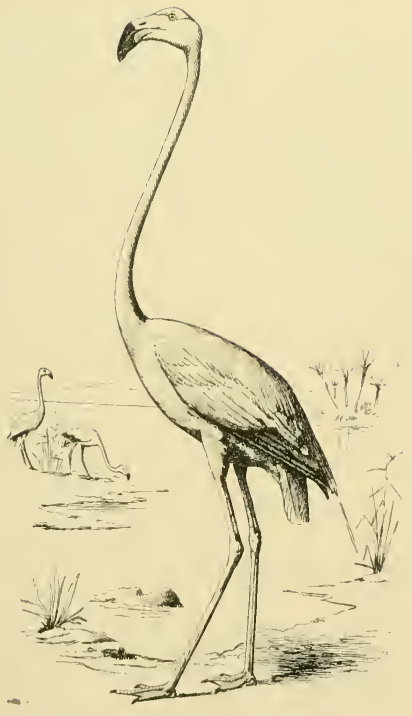

\section{PHENICOPTERUS RUBER Lim.}

American Flamingo.

Adult male: Entire plumage scarlet; most of the primaries black: legs lake red; terminal half of the bill black; basal half of lower mandible orange. The female and immature males are iighter colored and paler.

Length. 52; Wing. 17 ; Tail, 6.50; Tarsus, I 2.50; 13ill, 5.25 .

This species occurs on the coast of tropical and sub-tropical America. It is a resident in Florida, although seldom seen there. At one time it was abundant but is now only to be found in one or two localities. East of Cape Sable there was quite a colony of them, but the place is very difficult of access and they are very shy. This species is still abundant in the Bahama Islands, where I found it breeding. It lays two chalky-white eggs. The nest, which is constructed of mud, is shaped like a sugar-loaf slightly hollowed on the top, and usually from about $I_{t}$ inches to 20 inches in height. 


\title{
ORDER HEROIDIONES.
}

I Ierons, Storks, IbIses, Etr.

\author{
Suborder I bides. \\ SpoONBLlas ANI) IBIses.
}

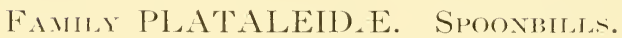

Genis AJAJA Reicui.

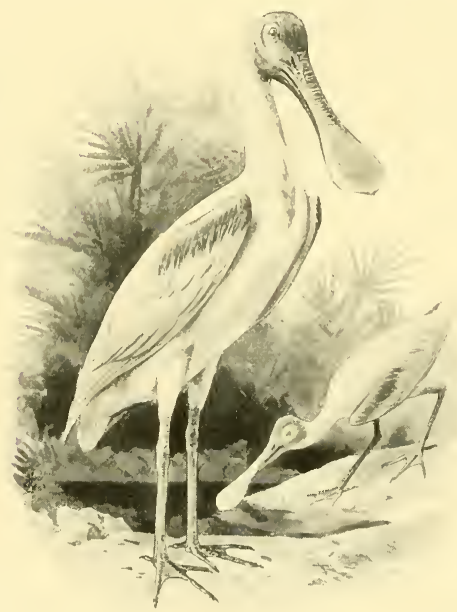

\section{AJAJA AJAJA (Linn.).}

\section{Roseate Spoonbill.}

Back and wings a delicate rose white; under parts showing rose color ; bare skin of the head greenish and yellow: bill widened at the tip, somewhat spoon-shaped but flat, tinted with greenish and yellowish; legs dull red. Very old birds have the lesser wing coverts and upper tail coverts brilliant carmine red.

The immature bird has general plumage pale pinkish white with no red on the lesser wing coverts.

Length, 3r ; Wing. I5: Tarsus, 4.10: Bill, 6.30. 
This species occurs in South America from the West Indies north to Florida and the Gulf States. It breeds in Florida, where it is known as "Pink Curlew," the nest being placed in mangrove bushes or low trees.

The eggs are usually four or five, being white and marked with olive brown. The bird is common on the Bahama Islands.

\section{FAMILY IBIDID.E. InIses. Gexis GUARA Reicit.}

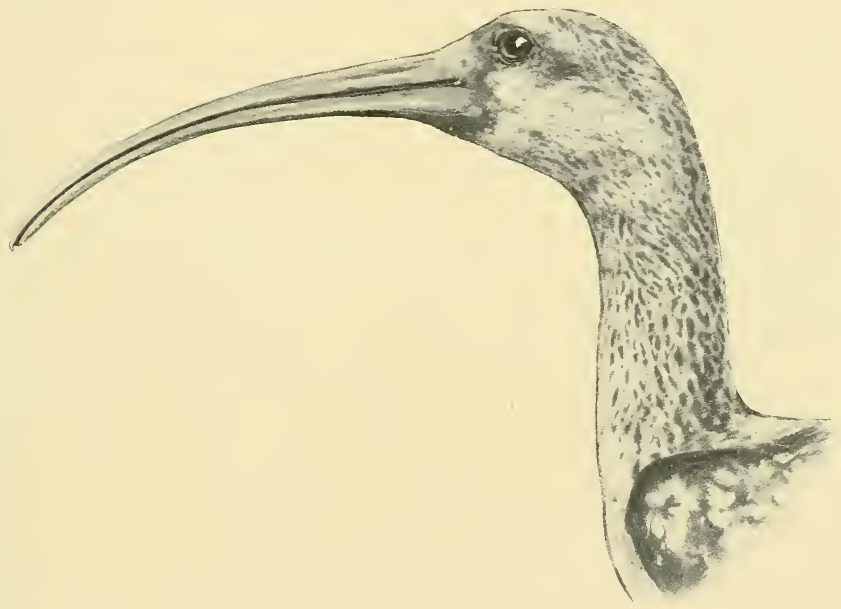

Guara alba (immeture).

\section{GUARA ALBA (Limn.).}

\section{White Ibis.}

General plumage white, with the four outer primaries tipped with black; the bare skin on the head is reddish orange. The immature bird is sometimes brown and white: sometimes gray. brown, and white, having the under parts white, and still younger birds are brown with a white 
rump and gray or grayish brown tail: the rump is always white, never brown, as in the young of the Scarlet Ibis. There is a great difference in size of individuals.

Adult: Length, 26: Wing, I 1.25: Bill. 6.30.

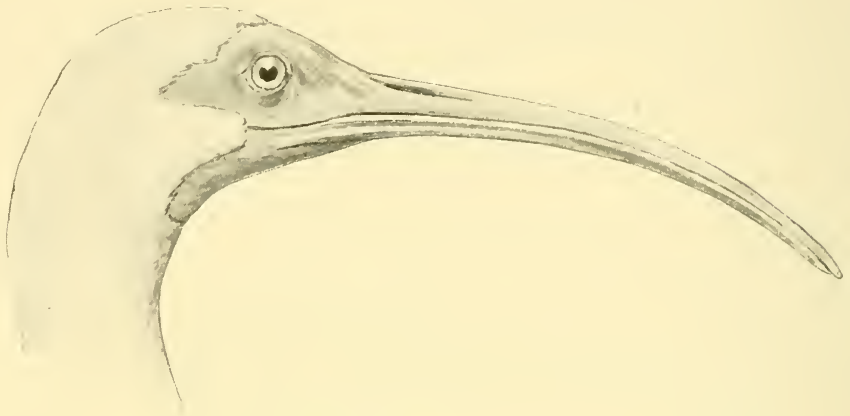

Guara alba (adult).

Ranges throughout tropical America and is claimed to have been found breeding as far north as Illinois and South Carolina, and it has been taken as far north as Long Island. It is a common species in Florida, where it breeds. The nest is a mass of grass and weeds placed in bushes and sometimes in trees. The eggs are usually from four to five, and greenish white in color marked with chocolate brown.

\section{GUARA RUBRA (lim.). Scarlet Ibis.}

Adult: General plumage scarlet; tips of the outer primaries black: bare skin of the head, bill, and legs red.

The immature are mixed brownish gray. pale on the under parts, having the rump brownish like the back.

The immature of this species may be easily distinguished from the immature of the White lbis by the color of the rump.

Adult: Length, 28: WVing, 11: I3ill, 6.50.

This species has but a very slight claim to be included among our birds. I know of no positive record of its capture in the United States. Audubon claimed to have seen this species in Louisiana but did not procure a specimen. 
Dr. Coues examined a fragment of a specimen taken near Los Pinos, New Mexico, in June, I864, and Mr. Brewster records a specimen in the museum at Charleston, S. C., which is labelled "Florida," and which he believes quite possibly might be an authentic specimen. [N.O. C., Vol. VIII., page I 85, I 883.$]$

This species has been recorded from Cuba and Jamaica but is a native of tropical America.

\section{Genus PLEGADIS Kaup.}

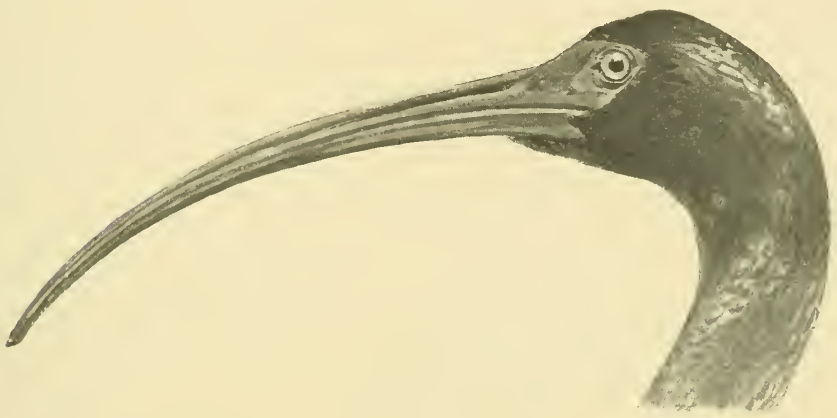

\section{PLEGADIS AUTUMNALIS (Hasselq.).}

\section{Glossy Ibis.}

Adult: General plumage chest nut ; wing coverts, back and front of head showing greenish and sometimes bronzy reflections.

The immature birds have the plumage more brownish and the front of the head slightly mottled; the back greenish; under parts dusky brown.

Length, 25: Wing, 11.25; Bill, 5.40.

Tropical America, not common in the United States. It occurs in Florida and has been taken in the West Indies. Specinens have occasionally been taken in summer as far north as Massachusetts. It has been recorded from Cambridge and I have a specimen in my collection which was shot at Eastham. Mass. The eggs are described as dull blue in color and are usually three in number. 


\section{PLEGADIS GUARAUNA ( Limn.). White=faced Glossy Ibis.}

Head chestnut, having a white patch on forehead, chin and bordering the bare space in front of the eye. Under parts purplish chestnut: upper part of back and wings showing metallic tints of purple. violet, and green: primaries greenish, showing a bronze luster: rump and upper tail coverts and tail greenish with purplish reflections.

Length, 25: Wing. 11: Bill, 5.50.

This species ranges throughout Western United States, south through Central America to South America, and has been recorded from the West Indies. It is a rare bird on the east coast, a single specimen having been found breeding near Lake $W^{2}$ ashington, Florida. [Brewster, Auk III.. I886, pagge +82.$]$

This species may be distinguished from the Glossy Ibis by the white at the base of the bill. It builds its nest in swamps, sometimes on bushes: the eggs are bluish.

\section{Suborder Ciconte. STORKi, ETL.}

Famly CICONIID.E. Storks and Mood IBIses. SubFAMILY TANTALINE. WoOn IBIsEs.

\section{Genes TANTALUS Jixx.}

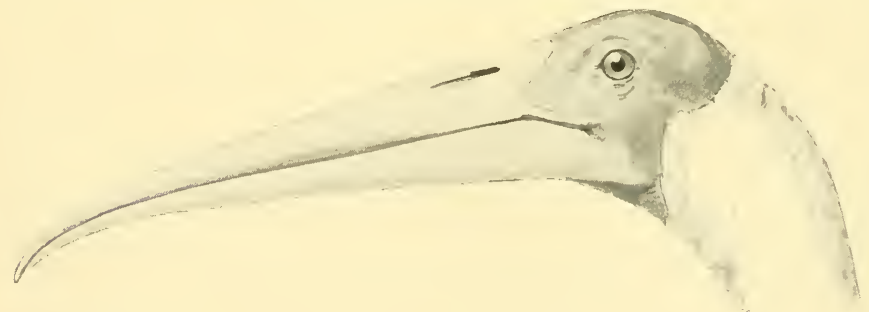

\section{TANTALUS LOCULATOR Linn. Wood Ibis.}

Adult: Having the head and neck bare: general plumage white; primaries, secondaries, and tail greenish black. 
The immature bird has the head feathered and the plumage grayish on the head and sometimes grayish white on the body.

Length, $4 \mathrm{r}$ : Wing, 18.50 ; Tarsus, 8.20: Bill, 9.20.

Ranges throughout Southern United States, wandering occasionally as far north as Pennsylvania and New York, and southward to Cuba, Jamaica, and South America. This species is common in Florida, where it breeds. It builds a large rough nest of sticks, which is placed in a tree. The eggs are usually three: they are white, and covered with a chalky deposit.
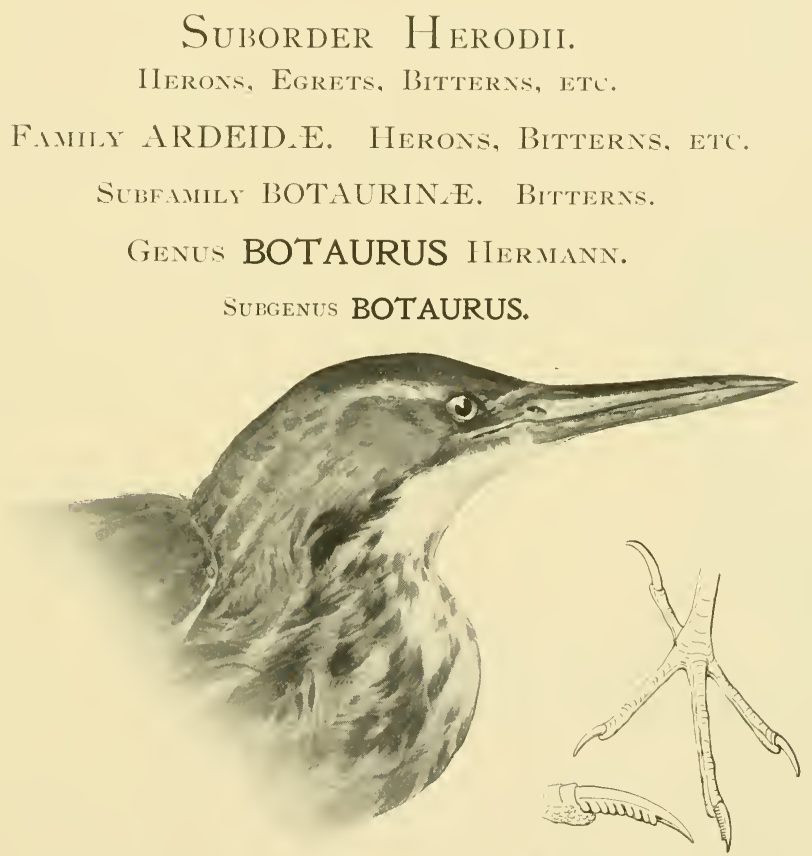

BOTAURUS LENTIGINOSUS (Montag.). American Bittern.

Lpper parts brown: wing coverts edged and mottled with tawny and buff and washed with ashy: top of the head and nape slaty with black streak on sides of the upper neck; neck and 
under parts tawny white: feathers edged with dusky and dull brown; legs greenish yellow: a loral stripe of dark brown: bill yellowish with a dark streak at the top.

Length, 27; Wing, 11.50: Bill. 3; Tarsus, 3.40.

The female is smaller than the male and the bird varies very much in size.

It ranges throughout temperate North America and is common on the Atlantic coast, breeding, as a rule, north of North Carolina. It ranges in winter south to Central America and the West Indies, being common in Florida in some localities.

The eggs are usually from three to five in number, grayish brown in color.

\section{GENUS ARDET'TA GRAY.}

\section{ARDETTA EXILIS (Gmel.). \\ Least Bittern.}

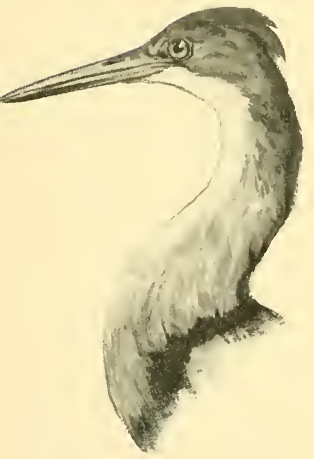

Adult male: Crown of the head black. extending into a small crest: back and tail black with a greenish tinge back of the neck; wing coverts chestnut brown; some of the wing coverts tawny yellow: front and sides of the neck and under parts yellowish brown, showing white on throat; a patch of brownish black on the sides of the breast: bill yellowish, dusky on the top: legs green, yellow on the back: toes yellow.

Adult female: Having the back and crown purplish chestnut instead of black.

Length, 12.50; Wing, 4.50: Bill, 2 ; Tarsus, 2.10.

This species ranges from temperate North America southward to the West Indies and Northern South America.

It breeds along the Atlantic coast nearly throughout its range. It is common in Florida where it breeds, being very abundant in some localities.

The nest is placed in a bunch of reeds or rushes, sometimes on small bushes.

The eggs are from four to six, pale bluish white. I have found as many as a dozen nests of this species within a distance of fifty yards on some of the small Florida ponds, but it seems to be local, as many ponds in the same locality, seemingly equally suitable, did not contain a single individual. 


\section{ARDETTA NEOXENA Cory. Cory's Bittern.*}

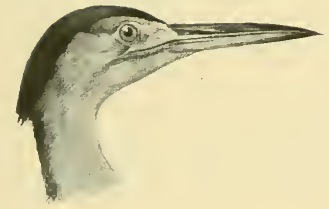

Top of the head, back, and tail dark greenish black, showing a green gloss when held in the light. Sides of the head and throat rufous chestuut; the feathers on the back of the neck showing greenish black tips; breast and under parts nearly uniform chestnut. shading into dull black on the sides; wing coverts dark rufous chestnut; all the remiges entirely slaty plumbeous : under tail coverts dull black.

Wing, 4.30; Tarsus, I.40; Bill, r.8o.

This interesting little Bittern was described by me in I 886 from a specimen taken in the Everglades of Florida. Since then a dozen or more specimens have been secured, most of them from Florida, but one was taken near Toronto, and another in Michigan. It is probably not uncommon in some localities, but its retiring disposition makes it seem rare, as it is seldom seen.

\section{Subfamly ARDEIN.E. Heroxs and Egrets. Genus ARDEA LinN. \\ Subgenus ARDEA. \\ ARDEA OCCIDENTALIS Aud. Great White Heron.}

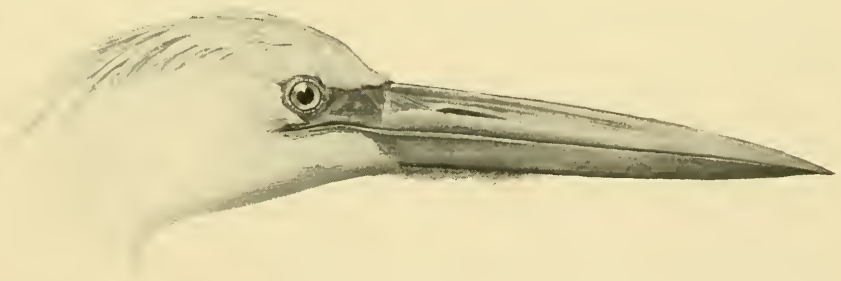

Adult: (ieneral plumage entirely white; bill yellow: upper part of the leg near the feathers, and soles of the feet yellow: the lower part of the leg from the knee to the foot (tarsus) yellow.

Length about 50: W'ing about I 8.50 to 20 ; Bill, 6.50: Tarsus, S.50.

* When I described this bird in 18861 gave it no English name, simply calling it woxena (new and strange). The committee of the American ()rnithologists' Union have since done me the honor of giving it my name. 
This species is resident in Florida, occurring most commonly in the southern part of the State. It has been recorded from Cuba and Jamaica. It is not common now and is becoming less so every year. The birds breed in colonies, the nest being a mass of sticks placed in mangrove trees. The eggs are usually from three to four, pale bluish in color.

\section{ARDEA WÜERDEMANNI Bairl. \\ Würdemann's Heron.}

Adult: Head and upper neck white, the forehead showing blackish edges to the feathers and faint streaks of black on the back of the head; neck grayish purple; rest of plumage somewhat resembling the Great Blue Heron, but the markings are paler.

Size about the same as Ardea occidentalis.

This bird is probably merely a color phase of occidcntalis. It is nowhere common and is seen so seldom that it is doubtful if its true standing will ever be known: still the preponderance of opinion among naturalists seems to be that it is simply a color phase of occidcutalis and should not be recognized as a species. Nearly all of the specimens now in collections have been taken on the southwestern coast of Florida.

\section{ARDEA WARDI Ridgzo. Ward's Heron.}

Adult: Similar to the Great Blue Heron but somewhat larger, especially the bill. The legs are olive instead of black, as a rule; bill usually yellow, dusky on the top, as a rule, but sometimes entirely yellow.

Wing, 20.50: Tarsus, 8.75 ; Bill, 6.50 to 7 .

This species seems to be restricted to Floricla; it breeds in communities, the eggs being apparently of the same color as those of the northern Blue Heron.

\section{ARDEA HERODIAS Linn.}

\section{Great Blue Heron.}

Crest lengthened; bill yellow, dark brown on top; legs and feet dark brown; soles of the feet yellow; a streak from the forehead to the middle of the crown white: sides of the crown and crest feathers black; neck grayish purple mixed with black and white; chin and part of the cheeks whitish, extending in a tawny line on the throat; neck plumes; belly black streaked with 
white: back and upper parts bluish slate or gray. The immature birds show a great variety of color in the plumage.

Length, $4^{S}$ : Wing, 20: Tail. 7 : Tarsus, 6.50; Bill, 5.50.

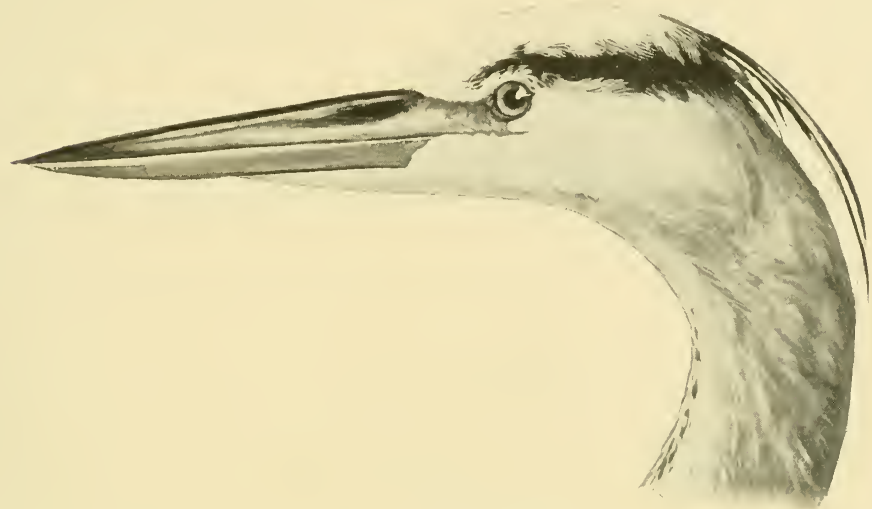

Ardea herodias.

It ranges throughout North America from the far North southward to the West Indies and South America. It is supposed to breed on the Atlantic coast from Florida northward, although I have never seen this species in Florida in the breeding season.

The nest, which is built in a tree, is a large affair composed of sticks. The eggs are from three to four in number and pale blue.

\section{Subgenus HERODIAS Boie.}

\section{ARDEA EGRETTA Gmel.}

\section{American Egret.}

Adult: Entire plumage white, having in the breeding season long graceful plumes on the back, which extend beyond the tail: bill yellow; legs and feet black; lores pale orange edged with greenish.

Length, ${ }_{3} 8$ : Wing, 16 ; Tarsus. 5.S०: Bill, 4.80.

This species ranges throughout tropical and temperate America, having been taken on the Atlantic coast as far north as New Jersey and Nova 
Scotia. It is a common species in Florida, where it is ruthlessly shot for its plumes. It breeds in colonies. The nest is a mass of sticks built in bushes or small trees. The eggs are from three to five in number and pale blue in color.

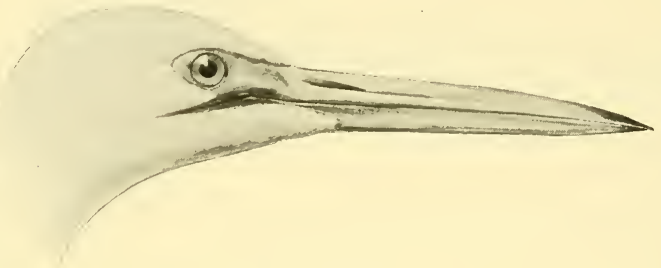

Ardea egretta.

Subgenus GARZETTA Kaup.

ARDEA CANDIDISSIMA Gmel.

Snowy Heron. White Egret.

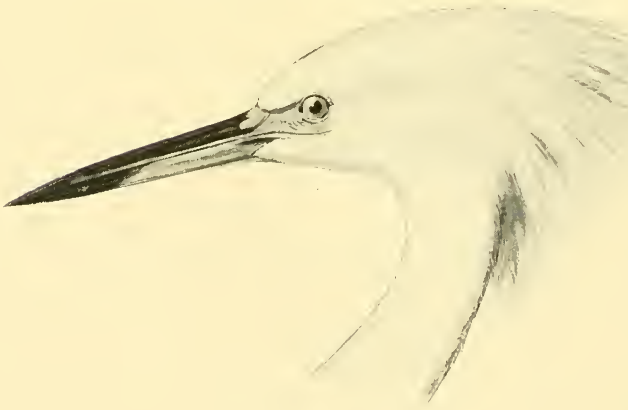

Ardea candidissima.

Adult: Entire plumage pure white, having in the breeding season extended plumes on the back and also feathers on the crest lengthened; bill black, becoming yellowish at the base; lores yellow; legs black; feet yellow.

Length, 22: Wing. 11: Tarsus, 3.50; Bill, 3 . 
This species ranges throughout tropical and temperate America as far south as Buenos Ayres, south America. It is very common in Florida, where it breeds, and has been known to breed as far north as Long Island. Stragglers have been taken in Nova sicotia.

The eggs are three to five in number and pale blue, as in most of this family.

This species is sometimes confounded with the immature of the Florida Blue Heron, which is also white, but that species has a faint wash of gravish on the tips of the primaries. Besicles having the primaries perfectly white without any wash near the tips, this species has the legs black, which in the immature of the Florida Blue Heron are greenish yellow.

Subgenus DICHROMANASSA Ridgw.

\section{ARDEA RUFESCENS Gmel.}

Reddish Egret.

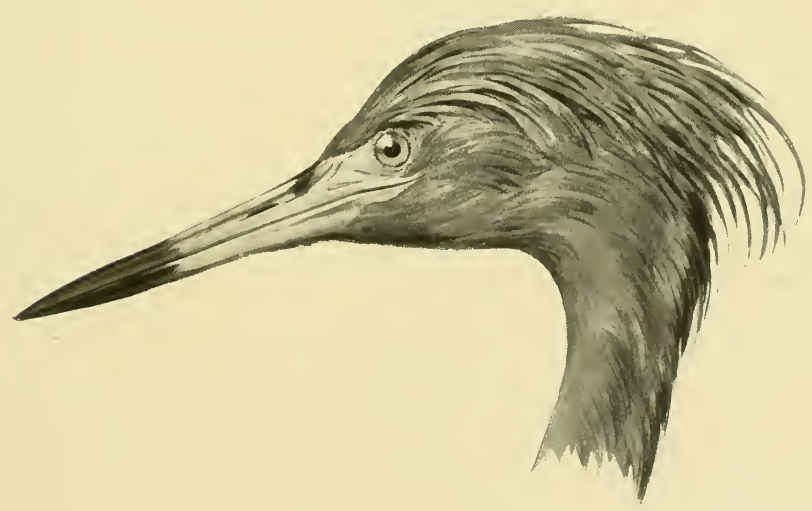

(Colored phase.)

Adult in colored phase: Head and neck lilac brown : rest of plumage dark slate color. This species has the long plumes extending from the scapular region of the back during the breeding season; legs and feet bluish, showing dusky on the scales of the tarsus. Bill black on the terminal third, the balance flesh color; iores flesh color. 
White phase: Entire plumage white: bill black on the terminal third; balance flesh color; legs greenish.

Length, 29: Wing, 14; Tail, 4 ; Tarsus, 5.30; Bill, 3.90.

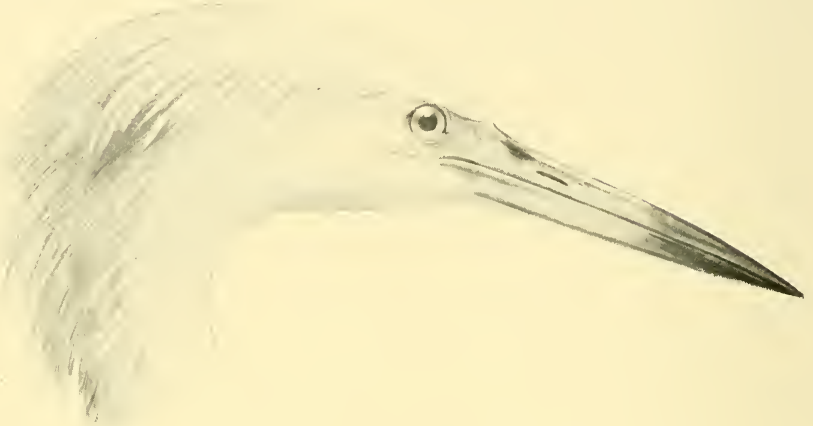

(White phase.)

For a long time the white phase of this species was considered to be distinct and was known as Peal's Egret. There can be no doubt as to its merely being a different phase of plumage and not a distinct species, as the young birds, both white and colored, have been taken from the same nest.

It usually breeds in Florida, the nest being built on the lower branches of a mangrove tree close to the water. I found this bird breeding in the Bahama Islands, and on June 25, I879, took a white and a gray bird from the same nest, neither of them being old enough to fly.

The eggs are usually from 3 to $t$ in number, being pale blue in color

Subgenus HYDRANASSA Batrd.

ARDEA TRICOLOR RUFICOLLIS (Gosse).

Louisiana Heron.

Adult male in breeding plumage: Terminal third of bill black, balance blue: lores blue in winter: bill black, yellowish at base: general plumage slaty blue; crest streaked reddish purple, 
mixed with dull white: throat white, mixed with reddish brown and purple, heaviest on the lower part, forming a stripe continuing down the front of the neck: under parts white; under tail coverts slightly edged with bluish; legs yellowish green : iris ied.

Length, 25: Wing. 10.50: Tail, 3.50: Tarsus, 4 ; 13ill, 4 .

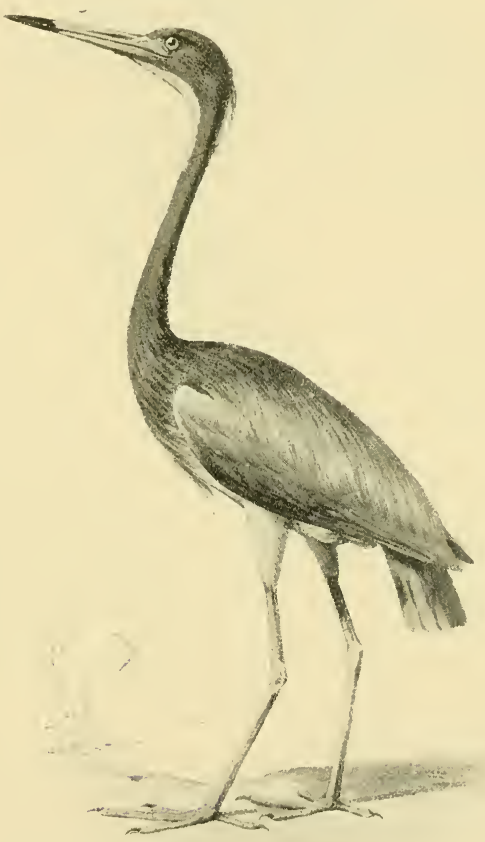

Ardea tricolor ruficollis.

Is common in the Gulf States, extending to Mexico, Central America, and the West Indies, accidental northward to New Jersey.

It is a common species in Florida, breeding in bushes near water. The eggs are usually four or five, pale blue in color. 
Subgenus FLORIDA Batri).

ARDEA COERULEA linn.

\section{Little Blue Heron.}

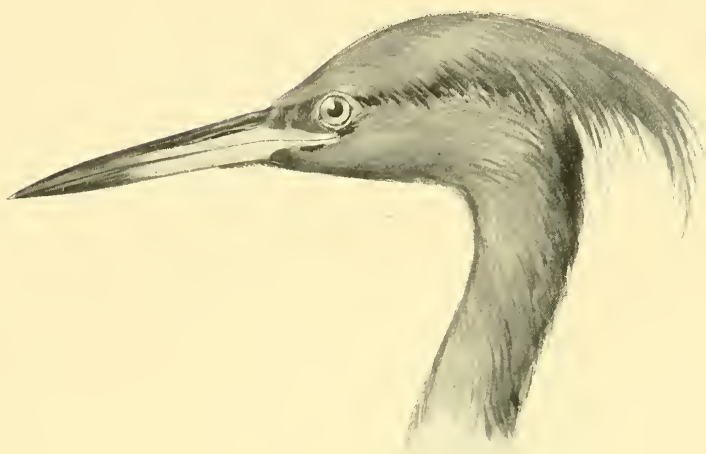

(Aduft.)

1dult: Head and neck purplish red or maroon, rest of plumage grayish blue; bill black at the end : basal portion and loral space blue; legs and feet black.

Immature birds are pure white, except a faint wash of grayish blue near the tip of the primaries; legs olive or yeilowish and the basal half of the bill greenish.

This species is sometimes confounded with the Snowy Egret, but may easily be distinguished from that species by the slight wash of blue on the ends of the primaries and by the color of the legs and bill.

Length about 23: Wing, II: Tarsus, 3.60.

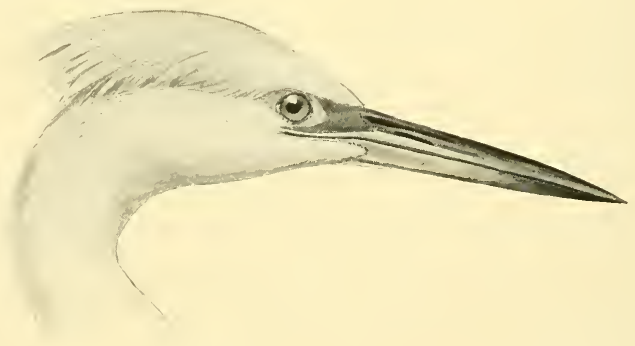


It ranges in winter from the Southern United states to the West Indies and South America: north in summer accidentally to New England.

It breeds in Florida, building a nest of sticks in bushes and small trees, usually over water. The eggs are three to four in number and pale blue.

Supgenus BUTORIDES BLyth.

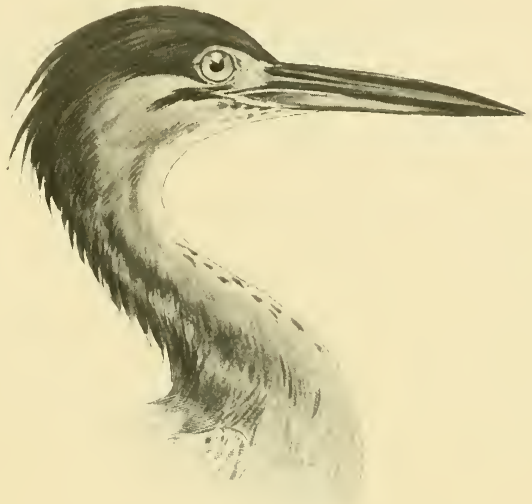

Ardea virescens.

\section{ARDEA VIRESCENS Lim.}

\section{Little Green Heron.}

Top of the head extending in a small crest dark green: neck chestnut; throat marked heavily with white: under parts pale purplish or ashy marked with white; back greenish, showing tinge of slate color: wing coverts green, feathers edged with buffy white; bend of wing whitish : tail greenish, upper mandible black: lower mandible mostly yellow, dark on the top: legs yellowish green.

Length. 16 inches: Wing, 6.50; Tail, 2.40 : Tarsus, 1.85 ; Bill, 2.30 .

This species ranges from Canada southward to South America and the West Indies, being common and breeding throughout most of its range on the Atlantic coast. It is common in Florida, where it breeds.

The nest is usually placed on a branch of a tree overhanging water. The eggs are pale blue, usually four to six in number. 


\section{Gents NYCTICORAX Stephens.}

\section{Subgenus NYCTICORAX.}

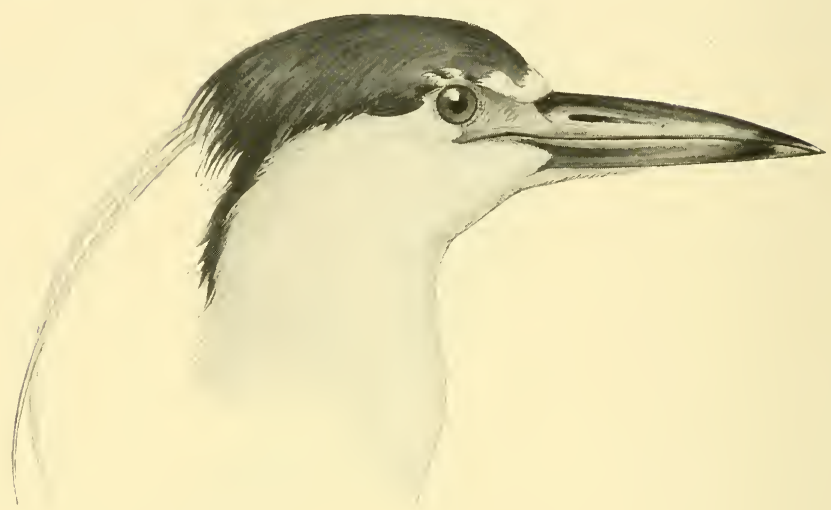

\section{NYCTICORAX NYCTICORAX NAEVIUS (Bodd.). Black=crowned Night Heron.}

Crown, head, back, and scapulars greenish black; forehead, lores, most of the neck and under parts white or ashy white. Wings and tail gray: legs and feet yellow: two or three very long occiputal plumes, white, in the breeding season.

Length, 24 to 26 : Wing, 11 ; Tarsus, 3.10 to 3.40 ; Tail, 4.20 to 5.30 .

The immature bird has the general plumage mottled dark brown and gray, the feathers marked and streaked with pointed blotches of grayish or buff; outer web of primaries buff color; under parts streaked with black and white.

This species occurs on the Atlantic coast from Canada to South America and has been recorcled from the West Indies. It is common in Florida. The nest is a mass of sticks generally built in trees or low bushes, rarely on the ground. All the nests that I personally have found have been built in trees or bushes. The eggs are four to six in number and pale blue. 


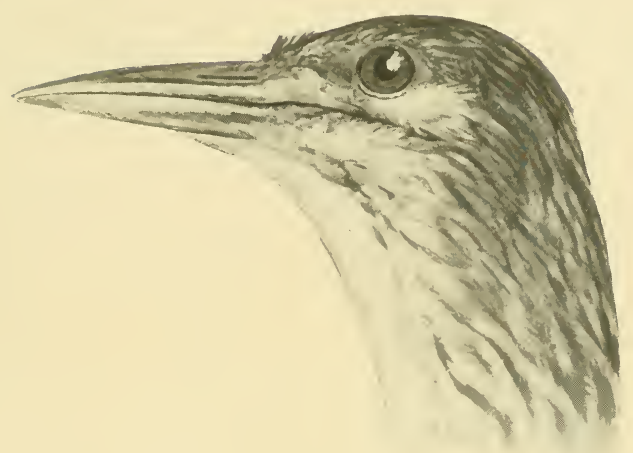

Nycticorax nycticorax nævius (immature).

Subgenus NYCTHERODIUS REICH.

NYCTICORAX VIOLACEUS (Linn.). Yellow =crowned Night Heron.

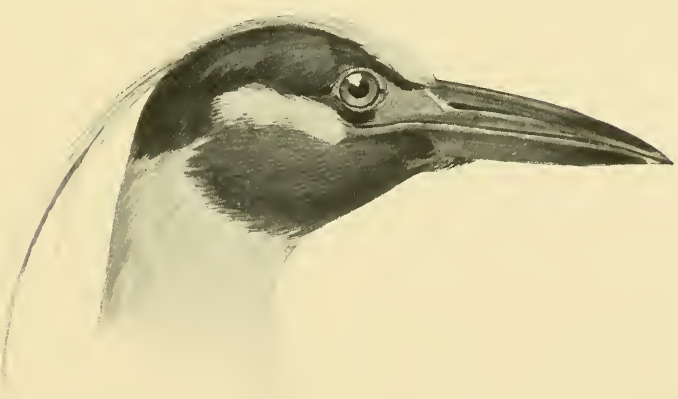

(Adult.)

Top of the head whitish buff extending into a crest; sides of the head black; throat black ; breast and under parts grayish plumbeous: back plumbeous : two or three very long feathers extending as long plumes from the crest : legs greenish. 
Length, about 23: Wing, 13.20: Tail, 4: Tarsus. 3.70: Bill, 2.60.

Immature birds have the crown dusky streaked with white or buffy white, the rest of the plumage heavily mottled, blotched with pointed marks of brown: also marked with buff and dull white. Primaries slate color, showing no rufous. The immature birds of this species somewhat resemble those of the Black-crowned Night Heron, but differ from it. having the head darker and no rufous on the primaries.

This species occurs in Eastern North America from the Carolinas south to South America and the West Indies. It has been recorded as far north as Massachusetts. It breeds commonly in Florida. The nest is built in trees, and the eggs are four or five in number and pale blue.

\title{
ORDER PALUDICOLA. \\ Cranes, Rails, etc. \\ Suborder Grues. \\ CRANES.
}

\author{
FAMILY GRUID.E. Cranes. \\ Genes GRUS Pallas.
}

\section{GRUS AMERICANA (Linn.). \\ Whooping Crane.}

Adult: Bare part of the head hairy : plumage white: primaries black: bill greenish; legs black: bare skin on the head carmine red. The immature birds have the head feathered and the general plumage brownish gray.

Length, 52; Wing, 23.50: Tail, 8.40: Bill, 6.10; Tarsus. 12.

This species is a rare bird on the Atlantic coast, although it was formerly not uncommon and has been recorded from New England. It now inhabits 


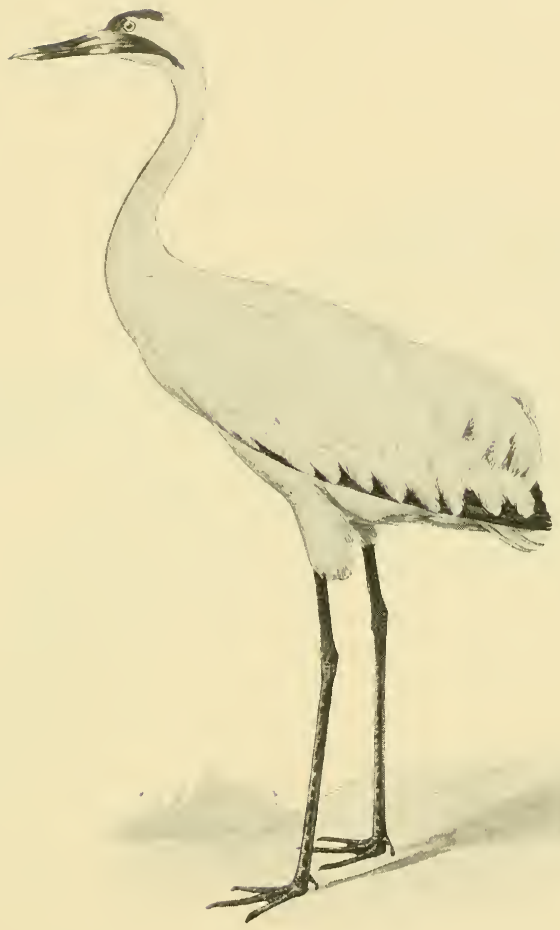

Grus americanus.

the interior of North America from the fur countries south to Texas and Mexico, and is supposed to be occasionally found in Florida. I have never met with it in Florida and it must be considered a rare bird in the State. It breeds from Illinois northward, the eggs being two, pale grayish green, blotched and marked with dark brown. 
GRUS MIEXICANA (Mïll.).

Sandhill Crane.

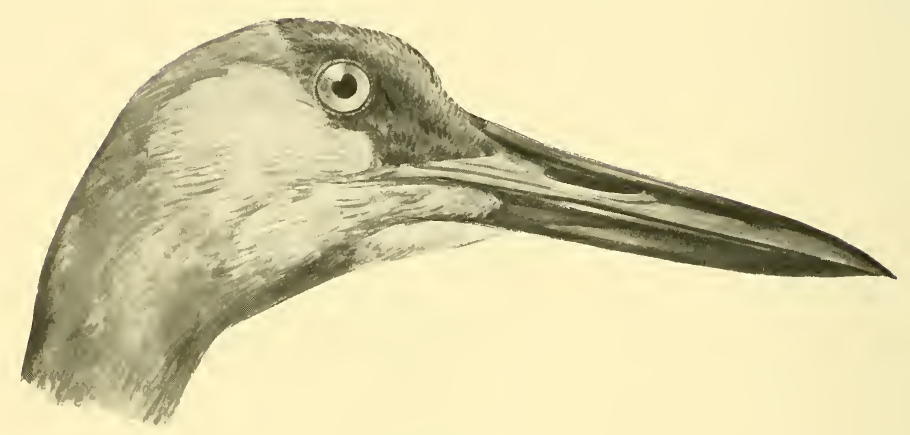

Girus mexicana.

Adult: Having the bare skin on the top of the head deep red; general plumage brownish gray, sometimes buffy gray on the back: legs black.

Length, 46; Wing, 21.50; Tarsus, ro: Bill. 5.30.

This species ranges throughout the southern half of North America, being common in Florida and some parts of Georgia. It breeds commonly in Florida, the nest being a pile of sticks sometimes built in the middle of a shallow pond, and again the bird simply deposits the eggs in some open piece of dry ground with no attempt at a nest. The eggs are two in number, grayish olive marked with dark brown. The note of the Sandhill Crane somewhat resembles the sounds made by the blocks when hoisting sail on a ressel. 


\author{
Suborder Ralli. \\ Rinls, Gillinules, Coots, ETe: \\ Finily ARAMIDAE. Courlass. \\ Genus ARAMUS Vieill.
}

ARAMAS GIGANTEUS (Bonap.).

Limpkin.

General plumage dark olive brown striped with white, the stripes on the body being much heavier than those on the head and neck; wing and tail showing bronzy reflections when heid in the light; under mandible slightly twisted near the tip.

Length, 27.50; Wing. 13; Tarsus, 4.35: Bill, 4.50 .

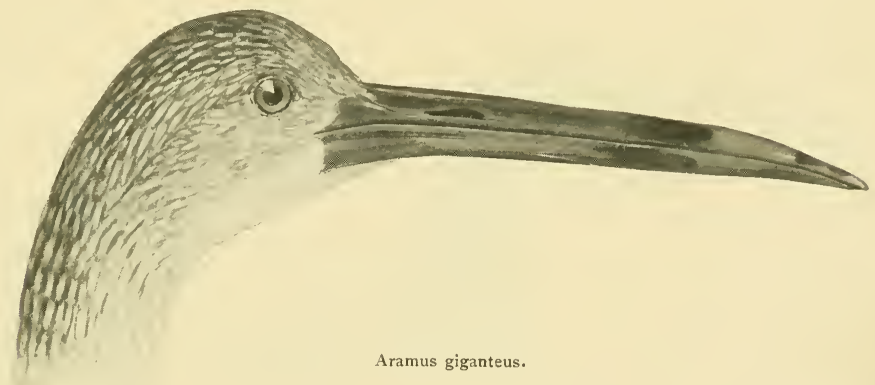

This species occurs in Florida on the Atlantic coast and Central America and in many of the West Indies.

It is resident and breeds in Florida, the nest being composed of leaves and twigs, which is placed in a tree or bush near a river or in a swamp. The eggs are from five to seven in number and buffy white marked with dark brown. At one time it was a very abundant species, but is now seldom seen except in the less inhabited districts. It eats the land-snails which are so abundant in the cypress ponds on the borders of the Everglades. 
Fanim RAlidide. Ralls, Gallinules, and CoOts. Subfaill RALLiN.E. Rins. - Genus RALLUS Liñ.

\section{RALLUS ELEGANS Aud. King Rail.}

Adult: Upper parts dark brown; throat white: breast reddish brown; sides darker barred with white; back and scapulars brownish margined with olive gray; wings and tail dull brown or olive brown; wing coverts rufous brown.

Length, 15.40; Wing, 6.55: Tarsus, 2.25: Bill, 2.50 .

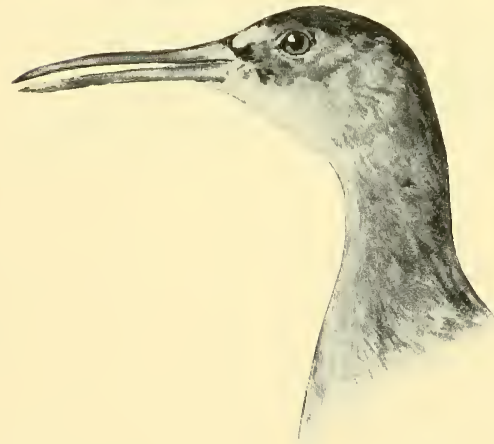

Rallus elegans.

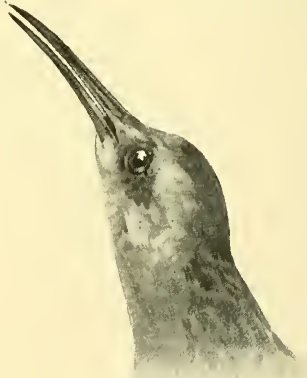

Rallus virginianus.

This species inhabits the fresh water marshes of Eastern United States from New England southward.

It is not uncommon in Florida, where it breeds. The eggs are generally from nine to twelve, pale brownish white, spotted with reddish brown. 


\section{RALLUS VIRGINIANUS Lim.}

\section{Virginia Rail.}

Adult: Having somewhat the appearance of a very small King Rail; upper parts are dusky or blackish; feathers edged with grayish brown; wings brownish; under parts dark rufous brown; throat white : lores ashy white, shading into gray on the cheeks; flanks and under tail coverts barred and spotted with white and black.

Length, 9.40; Wing, 4.25: Tarsus, 1.35; Bill, 1.55 .

Ranges throughout North America from the British Provinces south to Central America and Cuba. It breeds from New England northward on the Atlantic coast, the nest being made of grass, and the eggs are six to twelve, pale brownish white, spotted with reddish brown.

\section{RALLUS LONGIROSTRIS CREPITANS (Gmel.). Clapper Rail.}

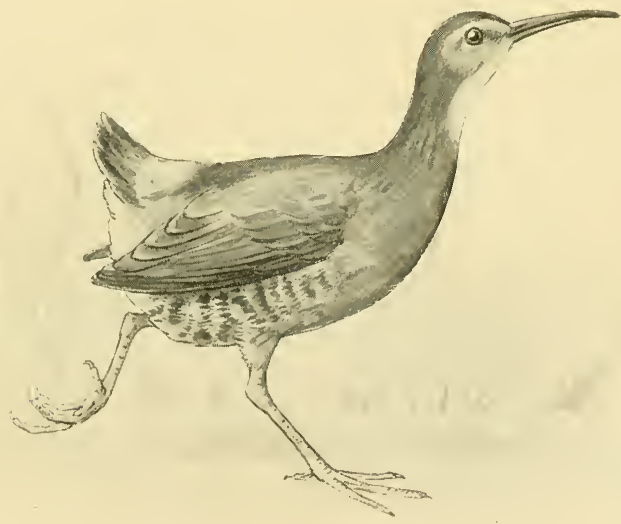

Adult : Upper parts dull olive: feathers edged with gray ; throat white; breast pale grayish brown ; rest of under parts grayish brown barred with white on the sides; wing coverts cinnamon brown tinged with gray.

Length, I4.75; Wing, 5.10: Tarsus, 2.10; Bill, 2.60. 
This species differs from the King Rail in being much grayer on the upper parts and paler on the under parts. The Clapper Rail prefers salt water marshes. It ranges on the Atlantic coast from New Jersey southward, but has been recorded from Massachusetts. It is not uncommon in Florida, but is probably replaced in nearly all the Gulf States by the local form, known as Scott's Rail. The nest is a little grass on salt water marshes; eggs are from eight to twelve, pale brownish white spotted with dark brown.

\section{RALLUS LONGIROSTRIS SCOTTII (Sem.). Florida Clapper Rail. Scott's Rail.}

Adult: Similar to the preceding species but darker in color and more brownish above; breast rufous brown; Hanks blackish. Both this and the Clapper Rail differ from the King Rail in the color of the wing coverts, which are much more highly colored in that species.

Range: Gulf coast of Florida.

\section{Genus PORZANA Vieill.}

\section{Subgenus PORZANA.}

\section{PORZANA CAROLINA (Limm.). Sora. Carolina Rail.}

Above reddish brown, streaked with black and some of the feathers edged with white; flanks and linings of the wings barred with white and black: abdomen dull white; a stripe of black passing from the bill down the center of the throat but not reaching the breast; whole of the breast, a cheek patch and superciliary line slate color; crown chestnut with a black stripe through the center; carpus elged with white; crissum rufous, shading into whitish.

Length, 7.75: Wing, 4.20: Tail, 2; Tarsus, 1.38; Bill, .75.

Ranges from temperate North America south in winter to Northern South America; it is common in Florida during the migrations. It breeds from Long Island northward; the eggs are from ten to fifteen in number, pale brownish white spotted with dark brown. 
Suigenus COTURNICOPS Bunap.

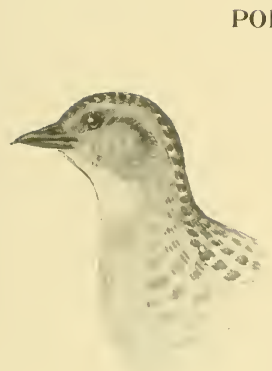

PORZANA NOVEBORACENSIS (Gmel.).

Yellow Rail.

Above, streaked with blackish and yellowish brown: feathers barred and mottled with white: under parts yellowish brown, palest on the belly: feathers of the breast tipped with dark brown; under surface of wings white; a pale yellowish brown superciliary stripe.

Length, 6: Wing, 3 to 3.50 : Tarsus, .90 to 1.00 .

This species ranges from Hudson's Bay to Cuba. It is not uncommon in Florida. I have seen several specimens which have been killed by people while snipe shooting. I have shot two specimens on the marshes bordering the St. John's River. The eggs are described as pale, creamy buff in color, speckled and sprinkled with rusty brown.

Subgenus CRECISCUS Cabanis.

PORZANA JAMAICENSIS (Gmel.).

Black Rail.

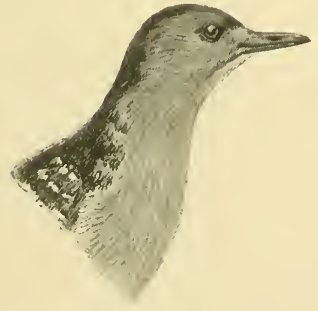
ten, being dull white speckled with reddish brown. I have never met with it in Florida, but Mr. Wr. E. D. Scott records it in his list of the birds of the Caloosahatchie region. ( $14 k$, t. 200, 1892.) 


\section{Subamily GALLINULIN/E. Gallintles. \\ Genus IONORNIS Reich.}

\section{IONORNIS MARTINICA (Lim.). \\ Purple Gallinule.}

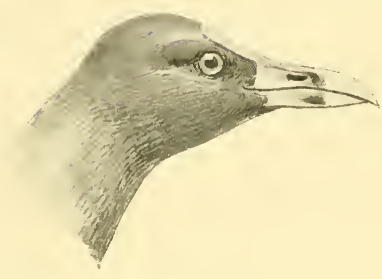

Adult male: Head, neck, and under parts bluish purple, grading into black on the belly: above olive; wing coverts bluish : back olive; crissum white; frontal plate of the bill blue; bill red tipped with yellow; legs yellow.

Length, I1; Wing, 6.50; Tail, 2.65; Tarsus, 2.30.

This species is resident in Florida and has been taken on the Atlantic coast as far north as Maine. Ranges in winter to the West Indies and Northern South America.

The eggs are eight to ten, pale buffy white, dotted with brownish. The nest is a mat of grass on reeds or in marshes.

\section{Gents GALLINULA Brisson.}

\section{GALLINULA GALEATA (Licht.).}

Florida Gallinule.

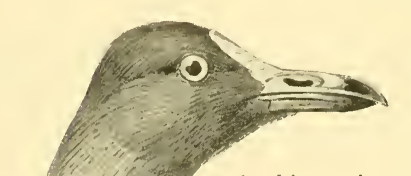

Head blackish; bill tipped with green, rest of bill and frontal plate deep red; upper back slaty; lower back and wings olive brown; under parts dark slate color ; lower belly grayish; feathers faintly tipped with white; some of the feathers on thesides having the inner webs white near the tip, giving the appearance of white stripes; under tail coverts black: tail white and black ; legs olive green, reddish near the body.

Length, I3; Wing, 6.60; Tail, 3.10: Tarsus, 2 ; Bill, including frontal shield, 1.75; Bill. from gape, 1.25.

Ranges throughout temperate and tropical America from Canada to South America. It is a common resident in Florida and has been known to breed as far

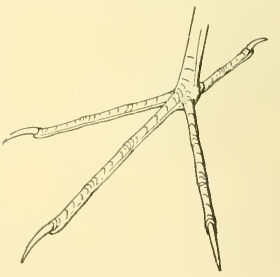
north as Maine. The nest is built in marshes, being a mass of grass or 
rushes; the eggs are from eight to thirteen in number, pale brownish white spotted and speckled with brown.

\author{
Subanily FULICINA. Coots. \\ GENUS FULICA LINN.
}

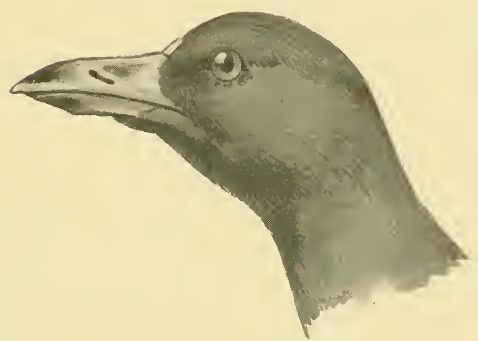

Fulica americana.

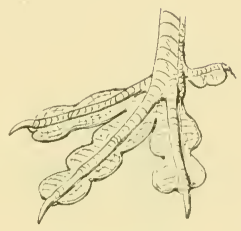

Fulica americana (foot).

\title{
FULICA AMERICANA Gmel.
}

\section{American Coot. Mud=hen.}

Adult: (ieneral plumage dark slate color; head and neck blackish; bill whitish marked with reddish black on the upper mandible; frontal plate brownish white; legs and feet dark olive, the toes having peculiar semicircular flaps or webs; abdomen grayish ; edge of wing and ends of secondaries white.

Length, 14.75 : Wing, 7.45; Tail, 2.30; Bill, from front edge of frontal plate, 1.40.

It ranges in North America from New . Brunswick south to the West Indies and Central America, being common in Florida, where it is resident.

It breeds in the marshes. The eggs are from eight to fifteen, which are pale brownish white in color and marked with dark chocolate brown.

This species may be easily distinguished from the Gallinule by the peculiar rounded tlaps or webs on the toes, and by the different color of the frontal plate. 


\section{ORDER LIMICOLA.}

SHORE BIRTS.

\section{Fanily PIALAROPODID. E. Phalaropes.}

\section{Genus CRYMOPHILUS Vieill.}

\section{CRYMOPHILUS FULICARIUS (Lim.). Red Phalarope. Gray Phalarope.}

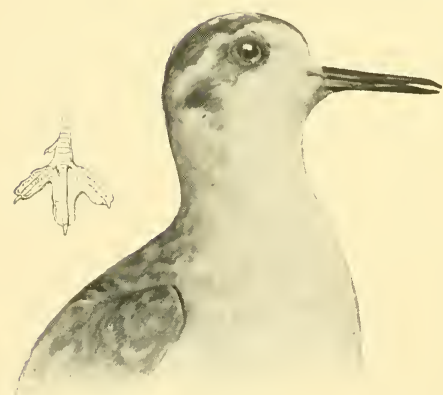

Adult male in summer: General under parts and sides of the neck purplish brown; upper tail coverts purplish brown slightly darker than the under parts; crown of the head and base of the bill smoky black; sides of the head white extending to the nape: rump white; back black; feathers edged with tawny brown; primaries dusky, the shafts being white and the base of the feathers white; some of the secondaries white; bill yellowish brown, dark on the tip; feet dull yellow.

Adult in winter: Head and under parts white, a small patch around the eye and a nuchal crest dusky; the under parts of the body are tinged with ashy gray on the sides; upper parts grayish ash color; wings showing a distinct white bar; bill dusky: feet brownish.

Length, 7.45; Wing, 5; Tail, 2.50; Bill, .94: Tarsus, .70.

This is a maritime species which ranges from the far north, where it breeds, southward to the Middle States. It is claimed to be occasionally seen off the coast of Florida, and I once purchased a stuffed specimen (which may or may not have been taken in Florida) from a dealer in Jacksonville, with a number of other skins of Florida birds.

The eggs are laid on the ground, the nest being formed of a little grass, and are from three to four in number, pale olive marked with chocolate brown. 
FAMILY RECURVIROSTRID.E. AVOCETS AND STILTS.

\section{GENUS RECURVIROSTRA LINN.}

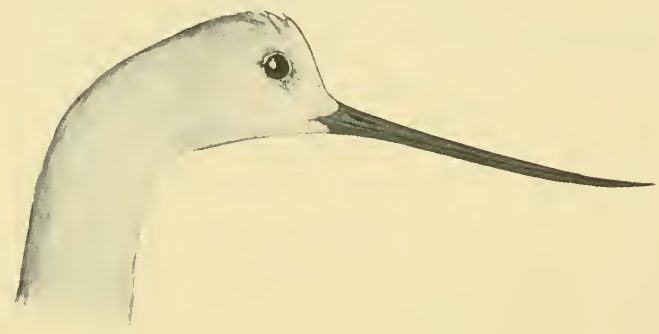

Recurvirostra americana.

\section{RECURVIROSTRA AMERICANA Gmel. \\ American Avocet.}

Adult in summer: Bill very slender and curved upwards; feet partly webbed; general plumage white, becoming cinnamon brown on the head and neck. but remaining whitish at the base of the bill; primaries black; most of the secondaries white, forming a broad white patch on the wing; tail ashy gray; legs bluish; bill black.

Adult in winter: Head and most of the neck ashy gray; tail ashy gray; rest as in summer plumage.

Length, IS to 20 ; Wing, 7.50 to 9; Tail, 3.50: Bill, 3.25 to 3.75 ; Tarsus, 3.6o.

This is a western species which ranges from the Great Slave Lake southward to Central America and the West Indies: is not common on the Atlantic coast north of Florida. Stragglers have been recorded as far north as the Bay of Fundy, but it is a very rare bird in New England.

The eggs are from three to four in number, pale gravish olive spotted with very dark brown. 


\section{GeNes HIMANTOPUS BRIs:.}

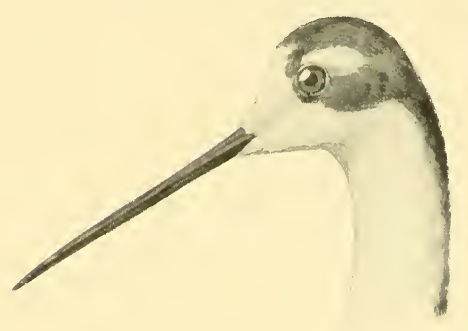

Himantopus mexicanus.

\section{HIMANTOPUS MEXICANUS (Mïll.). Black=necked Stilt.}

Adult: Top and sides of the head and back of the neck and back black; under eyelid and a spot above and behind the eye, forehead and sides of the head under the eye white; rest of under parts with the rump and upper tail coverts white; tail ash gray or pearl gray; bill black ; legs red in life.

The immature bird has the upper parts brownish ; feathers edged with whitish ; wings blackish, some of the feathers tipped with white; wing coverts edged with buff or tawny brown; under parts white mottled with black and tawny brown.

Length, 15.50; Wing, 9; Tail, 3: Tarsus, 4.25; Bill, 2.70.

This species is common throughout tropical America, occasionally being found in the Mississippi Valley as far north as Minnesota. It is accidental on the Atlantic coast north of Florida and Southern Georgia, although it has been recorded as far north as Long Island. It is common in Florida after April first, and breeds in the State.

The eggs are laid on the ground, sometimes on a little grass, and again without any nest whateves. They are three to four in number and pale brown or dull white, spotted and marked with chocolate brown. 
Family SCOLOPACIDA. Snipes, SAndpipers, etc.

\section{Genus PHILOHELA Griy.}

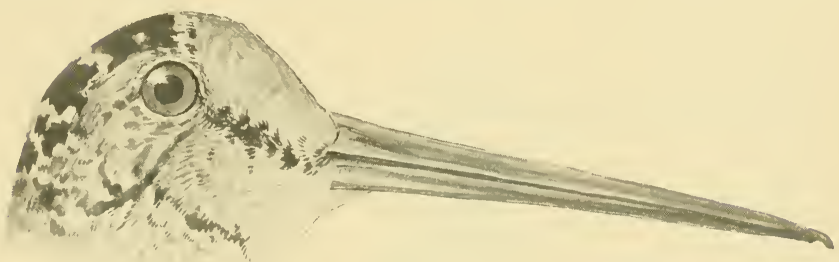

\section{PHILOHELA MINOR (Gmel.).}

\section{American Woodcock.}

Adult : Bill long, corrugated near the end ; upper parts variegated with tawny rufous brown and black; head rufous brown, banded on the occiput with alternate bands of black and tawny brown; a line of black from the eye to the bill : a narrow patch on the sides of the lower head, blackish; throat pale rufous or rufous white; under parts of the body pale rufous; quills brownish; tail feathers dusky tipped with ash; bill pale brown, yellowish at the base; legs reddish; bill light brown; paler and yellowish at base.

Length, 11.50; Wing, 5.45; Tarsus, 1.30 ; Bill, 2.90 to 3.05 .

Common on the Atlantic coast from Labrador to the Gulf of Mexico, breeding, as a rule, north of the Carolinas. It is occasionally observed in Florida in winter and is very abundant in the swamps of Alabama and Louisiana at some seasons. The eggs are usually four, mottled and spotted with brown.

\section{Genus GALLINAGO Leach.}

\section{GALLINAGO DELICATA (Ord). Wilson's Snipe. English Snipe.}

Bill long and straight, being slightly enlarged near the tip and showing numerous small pits; no web on toes; general upper parts dark brown, tawny brown, pale yellow, dull white; top of the head black with middle stripe of tawny brown; outer web of first primary white; greater 
wing coverts brownish or dusky with white tips; axilars and under surface of wings barred with black; upper tail coverts tawny brown barred with black; tail feathers chestnut brown with subterminal black bar; tips white and feathers marked with black at the base; under parts white; breast and throat speckled and lined with brown; sides of the body brownish barred with dull black.

Length, I I : Wing: 5; Tail, 2.20; Tarsus, I.25; Bill, 2.40 to 2.60 .

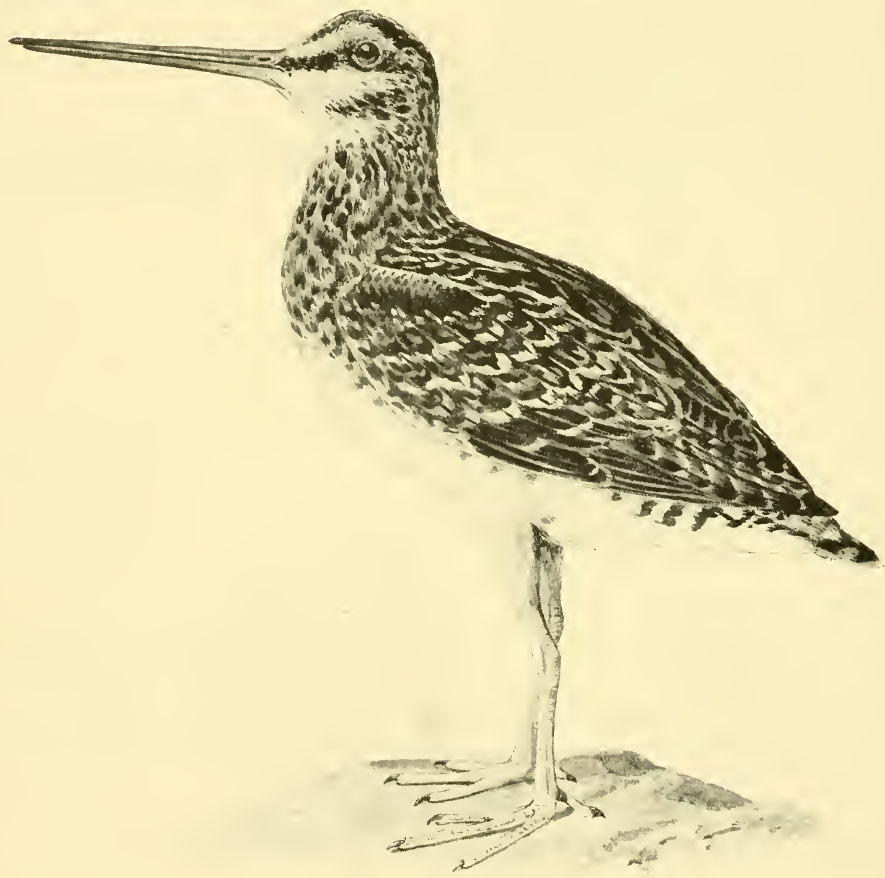

Gallinago delicata.

Ranges from Hudson Bay and Labrador south to South America. Breeds from New England northward. This species is common in Florida in winter, where it is found in great numbers on the fresh water marshes. It is common on the New England coast in the spring and fall, and occasionally a few remain to breed. 
The eggs are pale buff color spotted with chocolate brown, more numerously at the larger ends; bill brown (greenish gray in life), paler at base and darker toward the end.

\section{Genus MACRORHAMPHUS LeAch.}

\section{MACRORHAMPHUS GRISEUS (Gmel.).}

\section{Dowitcher. Red=breasted Snipe.}

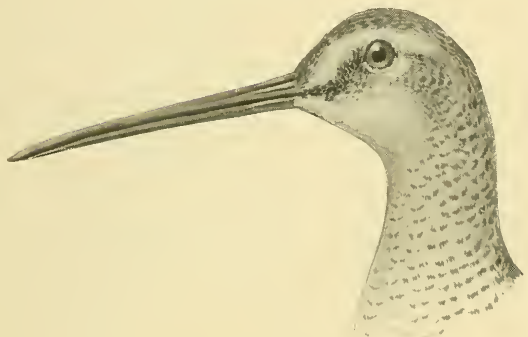

Adult in summer: A small web between the inner toes; upper parts blackish ; feathers edged with tawny brown; top of head blackish mottled with tawny brown; under parts red brown, banded on the sides; throat and breast only slightiy spotted, entirely without spots in some plumages; tail and tail coverts barred with black. Bill dark olive.

In winter : Upper parts grayish, feathers showing faint edges of buff on the back; chin and superciliary stripe dull grayish white; breast gray, showing slight traces of tawny; rest of under parts dirty white, mottled on the crissum; tail banded black and white.

Length, 10.30; Wing, 5.70; Tarsus, I.30; Bill, 2.20 to 2.50 .

Ranges from the Arctic Circle to South America; common during the migrations, being common in winter in Florida. It breeds in the far north, eggs being pale buff or dull olive mottled and speckled with dark brown.

\section{MACRORHAMPHUS SCOLOPACEUS (Say.). Long=billed Dowitcher. Western Red=breasted Snipe.}

Resembles the preceding species, but the bill is longer and the sides of the body are more distinctly barred with black; the principal difference is one of size.

Length, Ir ; Wing, 6.05; Tarsus, r.55; Bill, 2.20 to 2.60.

This is a western species, which occasionally occurs on the Atlantic coast. It is a common bird in Florida in winter. The eggs are similar in coloration to those of the preceding species. 


\section{Genus MICROPALAMA Baird.}

\section{MICROPALAMA HIMANTOPUS (Bonap.).}

Stilt Sandpiper.

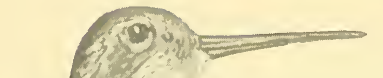

Adult in stummer: Legs long; entire plumage dull white and dark brown, being banded on the under parts with dark brown and the upper parts streaked with dark brown: a stripe of chestnut brown above and below the eye, the forner extending backwards and joining at the occiput; secondaries edged with tawny brown.

Adult in winter: Upper plumage gray; feathers on the back edged with white; breast pale buff slightly mottled, shading into dull white on the upper throat: belly duli white; bill black.

Length, 8.20; Wing, 5; Tarsus, 1.65; Bill, ı.6o.

This species ranges from the Arctic Circle to South America, being abundant on the Atlantic coast cluring the migrations; it is common in Florida. It has the general appearance of a very diminutive Summer Yellowlegs, having olive green legs instead of yellow.

It breeds in the far north; the eggs are pale buffy white, spotted with brown.

\section{Genus TRINGA LinN.}

\section{Subgenus TRINGA.}

\section{TRINGA CANUTUS lim.}

Knot. Robin Snipe.

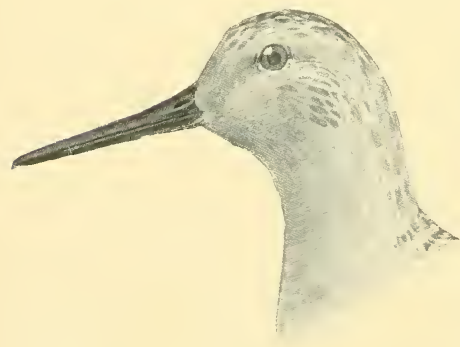

Male in summer: Under parts except lower belly reddish brown; lower belly white; a stripe of reldish brown over the eye; back and wing coverts mottled gray, black and tawny.

Adult in winter: Entire upper parts ashy gray; the shafts of the feathers on the back showing dark brown; a superciliary stripe, dull white; throat white; breast showing slight gray marking; belly white: legs black: bill black.

Length, 10.60; Wing, 6.70; Tarsus, 1.25; Bill, 1.30.

This species breeds in the Arctic regions, occurring on the Atlantic coast during migrations: it is common 
in Florida in fall and spring, a few remaining all winter. The eggs are clescribed as being light pea green in color, finely spotted with brown.

\section{Subgenus ARQUATELLA Baird.}

\section{TRINGA MARITIMA Brünn.}

Purple Sandpiper.

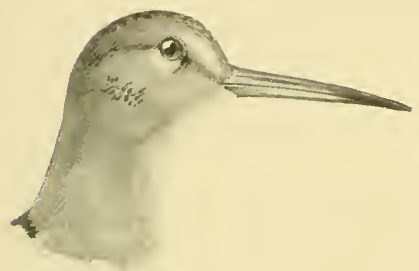

Adult: Upper parts gray, showing slight purplish reflections when held in the light; breast gray; throat grayish white; belly white, marked with gray on the sides; bill brown, yellow at base.

Length, 9.25: Wing, 5; Tarsus, .92; Bill, 1.30.

The Purple Sandpiper is a northern species, breeding in high latitudes, but occurring in winter on the Atlantic coast south to Florida, where it is by no means common, a specimen being occasionally taken on the west coast. Some birds remain on the New England coast all winter.

The eggs are buff, sometimes tinged with olive and mottled with brown.

Subgenus ACTODROMAS Kaup.

TRINGA MACULATA Vieill.

Pectoral Sandpiper. Grass Bird.

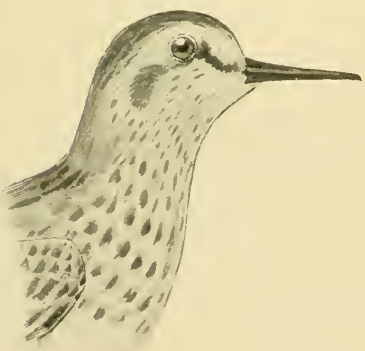

Head and upper parts brown, the feathers edged with tawny; throat and belly white; breast pale brown, the feathers narrowly streaked with dark brown; upper tail coverts black; basal half of bill dull greenish yellow.

Length, 9; Wing, 5.25; Tarsus, r.05; Bill, r.15.

This species ranges from the Arctic regions to South America, being common on the Atlantic coast during migrations. It breeds in the far north.

The eggs are greenish butf, mottled with brown, heariest at the larger end. 


\section{TRINGA FUSCICOLLIS Vicill.}

\section{White=rumped Sandpiper.}

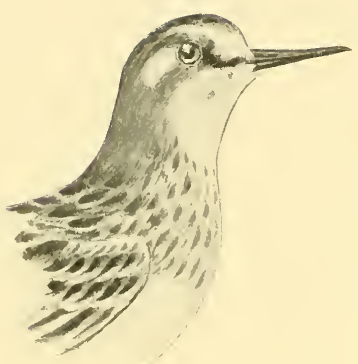

Idult in summer: Top of the head and back mottled with black, dull white, and buff ; throat white ; breast finely lined with dark brown: belly white: an imperfect superciliary line of dull white, rump dusky gray and most of upper tail cowerts white.

Adult in winter: Top of the head and back grayish, some of the feathers marked with dark brown, giving it a slightly mottled appearance on the back and top of the head; upper throat white; breast asby gray, the shafts of the feathers showing brown; belly white; forehead whitish, extending in an imperfect superciliary line.

Length, 6.S5: Wing, 4.95; Tarsus, .95: Bill, .95.

This species may be distinguished by the white upper tail coverts. It ranges from the Arctic regions south to South America and the West Indies. It breeds in high latitules; the eggs are buff or olive, spotted and dotted with dark brown.

\section{TRINGA MINUTILLA Iieill. \\ Least Sandpiper.}

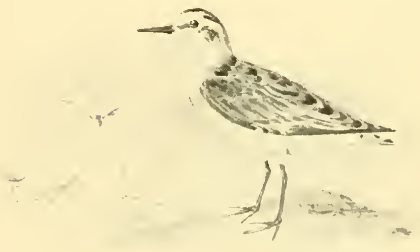

-Adult in summer: Very small; upper parts marked with tawny black and pale buff; under parts whitish on the throat, shading into ashy gray, showing faint brownish lines on the breast; rest of the under parts white; bill dull black. lo web between toes.

Adult in winter: Similar to the above but grayer in color.

Length, 5.50 to 6.50 ; WVing, 3.60; Tarsus. .75 ; Bill, .S5.

The Least Sandpiper may be distinguished from the Semipalmated Sandpiper by the absence of the small web between the toes, so noticeable in that species.

Common throughout North and South America, breeding north of the United States. Eggs are three to four, generally pale buff mottled with chestnut brown.

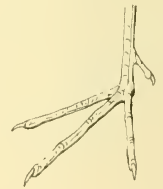


Subgenus PELIDNA Cuv.

\section{TRINGA ALPINA PACIFICA (Comes).}

\section{Red=backed Sandpiper.}

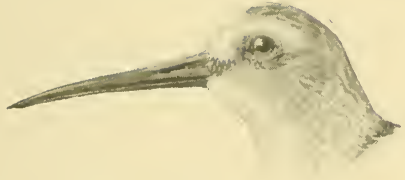

Adult in summer: The feathers on the top of the head and back bright rufous brown heavily blotched with black on the central part of each feather: throat whitish ; breast streaked with black : belly black on the upper part, becoming white on the lower belly and crissum ; bill black.

Actult in winter: Upper parts gray, slightly mottled; throat white: breast gray, the shafts of the feathers dark brown : helly and under tail coverts pure white; a faint dull white superciliary line.

Length, 8; Wing, 4.75: Tarsus, r.10: Bill, r.65.

Ranges throughout North America, breeding fär northward. It occurs on the Atlantic coast during migrations.

The eggs are buffy white, sometimes bluish white, mottled with chocolate at the larger end.

\section{Subgenus ANCYLOCHEILUS Kaup. Genus EREUNETES Illiger.}

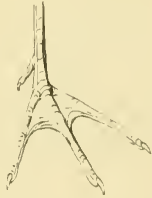

Ereunetes pusillus
(foot).

\section{Semipalmated Sandpiper.}

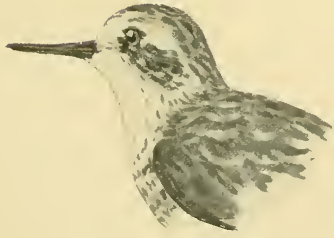

Adult in summer: Heavily marked with dark brown and tawny on the top of the head and back: forehead whitish : under parts and throat white; breast mottled with grayish ; belly white: toes with small web.

Adult in winter: Upper parts grayish, mottled with brown on the head, and the feathers showing dark brown edged with white on the back; throat white; breast very faintly washed with gray, which is sometimes very indistinct; belly and under tail coverts white; toes with small web.

Length, 6.25: Vring, 3.70; Tarsus, .75; Bill, .So.

Ranges from Labrador southward to the West Indies, and is common on the Atlantic coast during migrations. This species may be distinguished from the Least Sandpiper by the partly webbed toes. 
The eggs are buff white, mottled with brown and chocolate brown, heariest on the larger end.

\section{EREUNETES OCCIDENTALIS LaW Western Semipalmated Sandpiper.}

This species may be distinguished from E. pusillus by its longer bill, which is oftentimes I.25 inches in length, while E. pusillus rarely if ever has the bill one inch in length. Occasionally examples of the Western Sandpiper have the bill less than one inch, and in such cases it is almost impossible to distinguish them from the winter examples of E. pusillus; therefore it is perhaps as well for the sportsmen to consider all of those birds having bills less than one inch in length to be E. pusillus, and if it is important to have the identification absolutely accurate, they could easily obtain the opinion of some professional ornithologist to settle such a fine point.

Adult in summer: A small web between the toes; top of head brown; back reddish brown: the feathers marked with black and some of them tipped and edged with white; rump smoky black; under parts white, showing a faint tawny tinge on the breast.

Adult in winter: Top of head and back gray, showing brown on the shafts of the feathers forehead and under parts dull white; the breast faintly lined with grayish brown, sometimes entirely wanting.

Bill black, becoming greenish olive on basal part of the mandible.

Length, 6.50; Wing, 3.85 ; Tarsus, .82; Bill, .90 to 1.15 .

Occasionally occurs on the Atlantic coast, although its home is properly in the West. It is common in Florida in winter, more so on the West than on the East coast.

The eggs are pale buff dotted with dark brown.

\section{Genus CALIDRIS Cuv.}

\section{CALIDRIS ARENARIA (Lim.).}

\section{Sanderling. Bull=peep.}

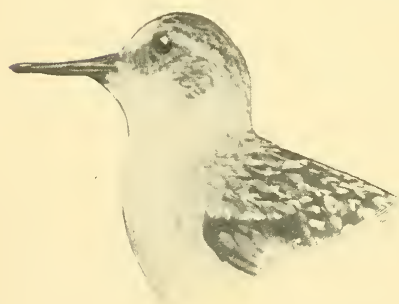

Adult in summer: Head, throat, and upper parts, except rump, reddish brown, black and white; belly and under parts pure white.

Adult in winter: Top of the head and back ash gray, the shafts of the feathers being brown; forehead and entire under parts white ; bill black.

Length, S. so: Wing, 5.05; Tarsus, I; Bill, r.

This species may always be distingruished by the absence of the fourth toe, being the only Sandpiper occurring on our coast having three toes. It is 
common during migrations, ranging from the Arctic regions to the West Indies and South America. The eggs are light olive and buff, spotted with brown.

\section{GENLS LIMOSA BRISSON.}

\section{LITIOSA FEDOA (limn.).}

\section{Marbled Godwit.}

Idult in summer: Bill curved slightly upward ; upper parts mottled with black and tawny: upper throat white, rest of throat finely streaked with brown: breast pale tawny, the feathers banded irregularly with brown; belly tawny, sometimes without bands; bill dull flesh color in its basal half, the rest blackish.

Adult in winter: Top of the head brown streaked with pale brown: feathers of the back dark brown edged with tawny; chin white; throat pale buff faintly lined with brown: under parts reddish buff; sides faintly barred with brown.

Length, 19; Wing. S.80; Tarsus, 2.80 ; Bill, 3.50 to 4.50 .

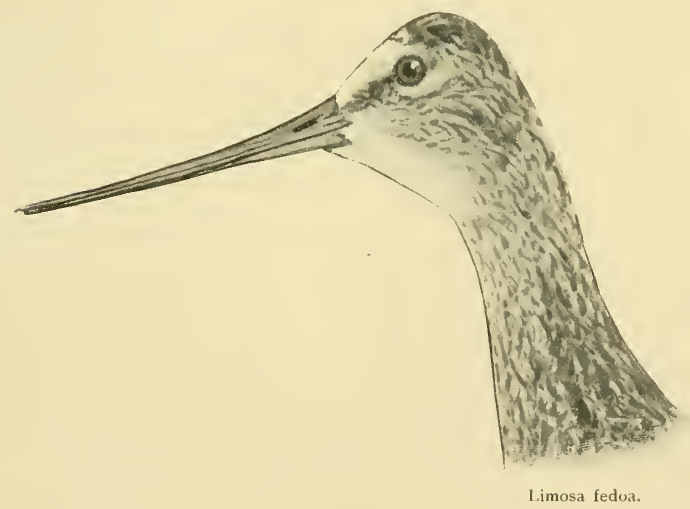

This species breeds in the interior from the Missouri region northward. It occurs in winter south to Florida and Cuba, but is not abundant anywhere - on the Atlantic coast.

The eggs are described as being from three to four in number and of a dull brownish ash color, blotched and mottled with gray and grayish brown. 


\section{LIMOSA HAEMASTICA (Limn.).}

Hudsonian Godwit.

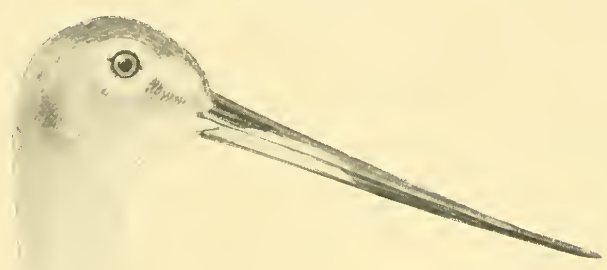

Idult in smmmer: Bill slightly curved up; top of the head dusky, showing pale brown streaks; back black, the feathers spotted with tawny brown. Upper tail coserts white; chin whitish dotted with dusky: throat reddish brown streaked with brown : under parts dark rufous brown, faintly and irregularly banded with black. Bill grayish yellow, dark brown along the ridge of the upper mandible, and blackish towards the tips of both.

Adult in winter: General plumage grayish: top of the head gray mottled with brown; back gray; some of the feathers tipped with dark brown and indistinctly edged with dull whitish; upper tail coverts white: chin white; throat ash gray: under parts grayish white.

Length, 15.50; Wing, 8.30: Tarsus, 2.30 ; Bill. 3 to 3.40 .

Ranges in Eastern North America from the far North south to South America. It is becoming less common every year, although at one time it was an abundant species, during the migrations, on our coast.

Breeds in the far North; the eggs are described as dark brownish olive lined and spotted with dark brown.

\section{Genus TOTANUS Bentht. SU bGenus GLOT'TIS Koch.}

\section{TOTANUS NEBULARIUS (Gum!.). Green=shank.}

This species has the general appearance of a Winter Yellow-leg (Totanus melanolouins), although the marking is somewhat different. It is a very rare bird on our coast, there being no actual record since Audubon's time, who states that specimens were taken in Florida, near Cape Sable. It may easily be distinguished by the greenish-gray legs and the dusky-green bill, which is dark at the tip, and the white rump.

Length, 14 ; Wing, 7.20; Bill, 2.30 to 2.50 ; Tarsus, 2.30 . 
TOTANUS MELANOLEUCUS (Gmcl.). Gireater Yellow=legs. Winter Yellow=legs.

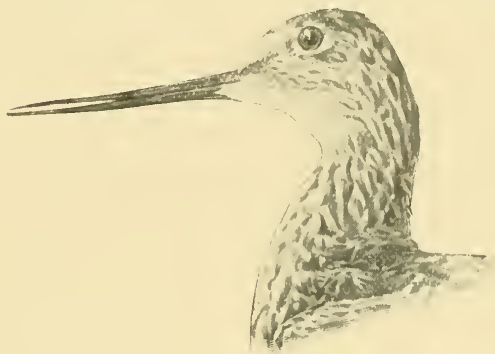

Adult in summer: Bill nearly straight; upper plumage mottled with white and black; throat white streaked with black; chin whitish; breast white heavily streaked with black; rest of under parts white irregularly marked with black: middle of belly nearly always pure white; bill black and legs yellow.

Adult in winter: Top of the head and neck streaked white and dark brown: back brown, the feathers narrowly edged with whitish; chin white; breast white, narrowly lined with dark brown; rest of under parts white: bill black and legs yellow.

Length, 14.50; Wing, 7.80: Tarsus, 2.50: Bill, 2.30.

Common in Eastern North America from the Arctic region southward to South America. It is abundant on the Atlantic coast during migrations: common in Florida in winter.

The eggs are pale buffy brown spotted with dark brown.

\section{TOTANUS FLAVIPES ( $G m \mathrm{l} l$.) \\ Summer Yellow=legs.}

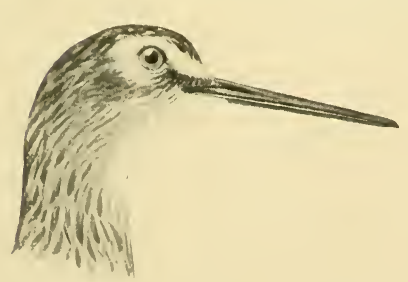

Upper parts grayish brown mottled with whitish on the back: chin white: throat white streaked with pale grayish brown; breast mottled, belly white; tail feathers banded brown and white; bill black: legs yellow.

Length, 10.80; Wing, 6.45; Tarsus, 2.10; Bill, I.45.

Ranges from the sub-Arctic regions southward to South America. Breeds in the interior from Minnesota and Illinois northward. The eggs are pale buff dotted and blotched with dark brown and chocolate brown. This is a well-known 
species on our coast during the migrations. It is common in Florida in winter, especially during migrations.

\section{Subgenus RHYACOPHILUS KaUp.}

\section{TOTANUS SOLITARIUS (ITils.). \\ Solitary Sandpiper.}

Adult in summer: Top of head and back bronzy green dotted with white: under parts white; the breast thickly streaked and dotted with brown; bill greenish brown (in life), dusky terminally.

Adult in winter: Upper parts olive brown, showing a faint greenish gloss when held in the light, the feathers faintly dotted with dull white: throat white: breast streaked with brown; rest of under parts white.

Length, 8.50; IVing, 5.30; Tarsus, 1.20; I:ill, I.30.

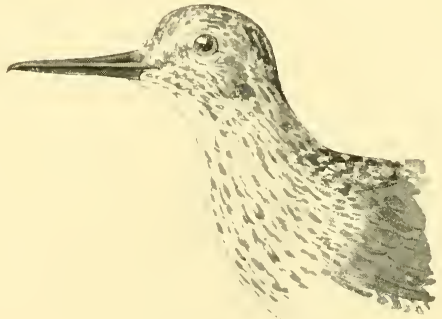

Totanus solitarius.

This species ranges from the sub- lrctic regions southward to South America. It usually occurs on our Atlantic coast during the migrations, and is not uncommon in Florida. It breeds from Pennsylvania and Illinois northward. The eggs, which are described from a single specimen taken by Jenness Richardson, in Vermont, and described by Dr. Brewer, are light drab with small rounded brown markings, having a few faint purplish marks on the larger end. 


\section{GENus SYMPHEMIA RAF.}

\section{SYMPHEIIA SEMIPALMATA (Gmel.).}

\section{Willet.}

Adult in summer: Upper plumage gray, streaked on the head with dark brown, and the central portion of many of the feathers has the back blotched with brown; chin white; throat white dotted with brown; under parts dull white, the feathers on the sides barred with brown and washed with tawny; axillars black; bill bluish, dusky toward end.

Adult in winter: IBill nearly straight, upper plumage gray, showing faint indications of whitish on the tips of some of the feathers on the back; chin whitish; throat ashy gray: the rest of under parts white, showing ashy on the sides of the body. The broad white band on the wings is a distinguishing character of this bird when flying, formed by the basal portion of the primaries and some of the secondaries being white.

Length. 15.50: Wing, 8.10: Tarsus, 2.30: Bill, 2 to 2.30.

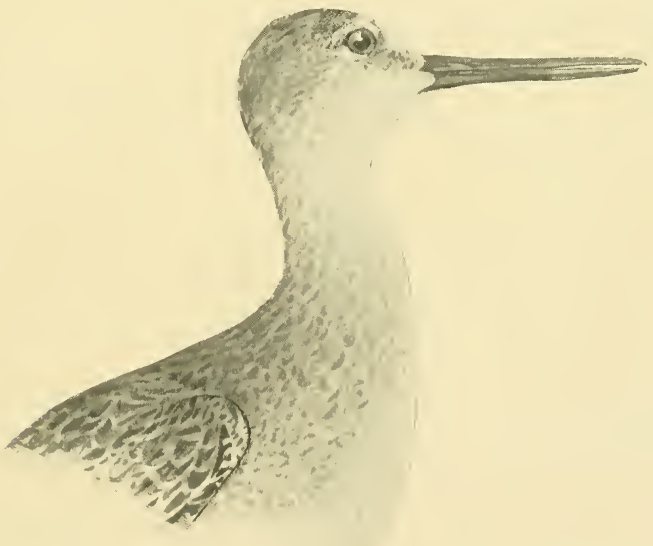

Symphemia semipalmata.

Ranges from temperate South America south to the West Indies and South America.

It breeds from New England to Florida, although it does not breed commonly north of the Carolinas. It is a rery common species in Florida, 
where it frequents the beaches and marshes, and may be easily clistinguished by its broad white wing band and peculiar whistle.

It is not likely to be confounded with any species, but a very good distinguishing character is the black axillars.

The eggs are three in number, sometimes four, deposited on the ground with scarcely any indication of a nest. They are pale buff in color, spotted with chocolate brown, heaviest on the larger end.

\section{SYMPHEMIA SEMIPALMATA INORNATA Prezest. \\ Western Willet.}

General resemblance to the preceding species, but the upper parts are paler and not so heavily marked with black; the breast shows usually more buff color. In winter plumage it resembles the eastern form except in size, the bill usually being longer and the bird somewhat larger.

Length, 15.60; Wing, 8.50: Tarsus, 2.55: Bill, 2.30 to 2.80.

It is a western species common in Florida in winter, its true range being from Texas to Manitoba.

\section{GENUS BARTRAMIA LESS.}

BARTRAMIA LONGICAUDA (Bechst.).

Bartram's Sandpiper. Upland Plover.

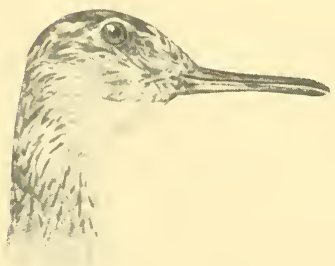

Adult: Head, upper parts, and breast mottled brown and tawny; belly white; first primary barred with a'hite.

In winter the bird is paler in coloration; throat white.

Length, 11.75; Wing, 6.60; Tarsus, 1.90; Bill, r.20.

This species occurs in Eastern North America, from Nova Scotia south to South America. It is not very common anywhere on the Atlantic coast nowadays, although at one time it was an abundant species. It occurs in Florida in winter. A good diagnostic character of this species is the barred primary. It breeds from Virginia northward. The eggs are four to five in number, of a pale brownish color, mottled with chocolate brown near the larger end. 


\section{GENUS TRYNGITES C.IBANIS.}

\section{TRYNGITES SUBRUFICOLLIS (I icill.).}

\section{Buff=breasted Sandpiper.}

Idult in breding plumage: Entire upper parts mottled with black and tawny brown, the feathers being black in the center and broadly edged with tawny; under parts pale rufous mottled with whitish.

Adult in winter plumage: Top of the head and nape pale tawny dotted with brown; feathers of the back blackish, narrowly edged with white; under parts pale buff. becoming

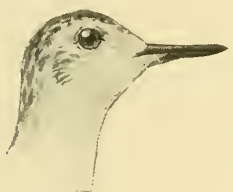
whitish on the belly, faintly mottled with brownish on the sides of the breast. Inner webs of primaries speckled.

Length, S; Wing, 5.30; Tarsus, 1.25 ; Bill, .S5.

Not abundant on the Atlantic coast, usually ranging in the interior. It breeds from British Anerica northward. It ranges in winter south to South America. being found on our coast during migrations.

The eggs are described as from three to four: pale buff white, spotted and lined with dark brown and purplish brown.

\section{Gents ACTITIS Ifligik.}

\section{ACTITIS MACULARIA (Limn.).}

\section{Spotted Sandpiper.}

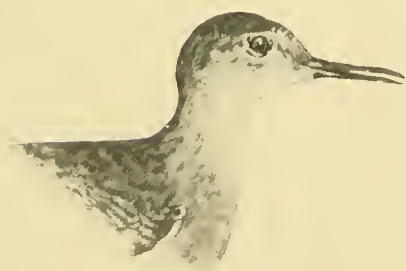

Adnlt in summer: Top of the head and back olive green, showing bronzy reflections when held in the light; some of the feathers on the back irregularly marked with brown; under parts white, marked with large spots of black.

Adnlt in winter: Above olive, showing a bronzy luster when held in the light: feathers on the back faintly tipped with dusky; wing coverts narrowly banded with tawny; throat white; breast, under parts, including belly and under tail coverts, white; mandible and edge of the maxilla pale wax yellow (in life), rest of bill black.

Length, 8; Wing, 4.20; Tarsus, I ; Bill, r.

Ranges from Itudson Bay to South America. It is a very well-known bird on our coast, being usually seen alone or in pairs. It is common on 
small streams of fresh water and also on sand beaches, usually selecting rocky places. It breeds nearly throughout its range, the eggs being buff white or pale brown spotted with dark brown, mostly on the larger end.

\section{Genus NUMENIUS Brisson.}

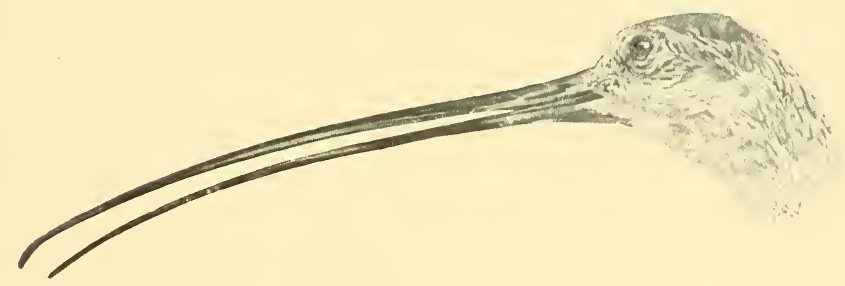

Numenius longirostris.

\section{NUMENIUS LONGIROSTRIS Wils.}

\section{Long=billed Curlew. Sickle=bill.}

Adult in summer: Upper parts marked with buff and black; tail feathers alternately banded with tawny buff and brown: throat whitish; rest of under parts pale reddish brown. becoming very light on the belly; breast narrowly striped with brown on the middle of the feathers: bill very long.

Adult in winter: General plumage tawny brown; the back blackish, mottled with buff; top of the head dark brown; the feathers edged with tawny; throat white; under part pale buff brown; feathers on the lower throat and upper breast finely lined with dark brown; bill very long and curved downward : bill black, becoming dull lilac brown on basal half of the mandible.

Length, 26; Wing, 10.50; Tarsus, 2.30: Bill very variable, measuring from 2.50 to 9.

The immature of this species has the bill nearly straight but quite short, sometimes not exceeding two inches in length.

Ranges from temperate North America south to Central America and the West Indies. It breeds in the Southern Atlantic States, but is now not common on the Atlantic coast, and is becoming less so every year. The eggs are described as olive gray in color, spotted with chocolate brown. 


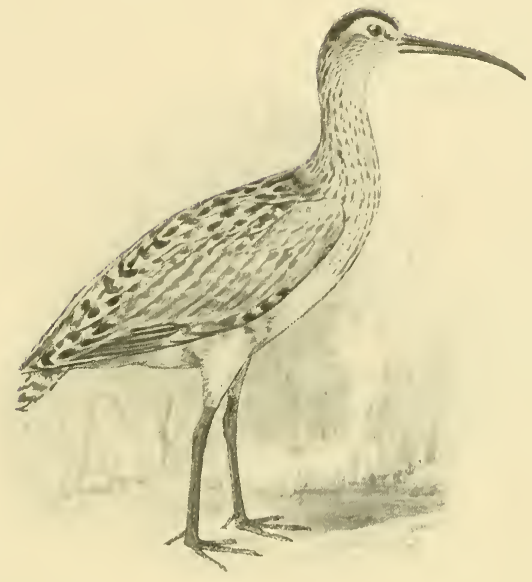

NUMENIUS HUDSONICUS lath.

Hudsonian Curlew.

Adult in summer: Bill curved downward; top of the head brown, with a stripe of buffy white through the middle; rest of upper parts dark brown; feathers pale on the edges, giving a slightly mottled appearance to the back; chin white; throat and breast streaked and faintly barred with brown and white; belly dull white; an imperfect superciliary stripe.

Adult in winter: Similar to the last, but showing much more tawny mottled on the upper parts, and the under parts paler; a superciliary stripe of dull white.

Length, 17.50: Wing, 9.20; Tarsus, 2.30; Bill, 3 to 3.75 .

Common in North America, south in winter to South America and the West Indies. Breeds in the far North.

It is one of the well-known birds on the Atlantic coast, occurring during the migrations.

This species may always be distinguished from the Esquimo or Longbilled Curlew by the buffy stripe on the middle of the crown. The eggs are described as three or four in number, grayish olive spotted with brown. 
NUTIENIUS BOREALIS (Forst.).

Eskimo Curlew. Dough Bird.

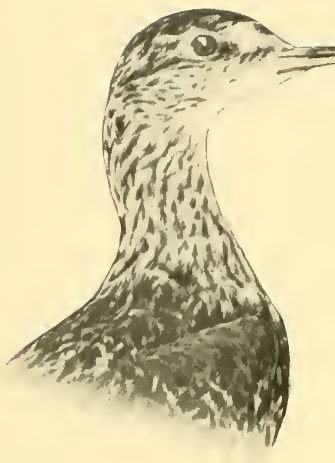

Adult in summer: Bill curved downward, general plumage above mottled black and tawny; chin whitish; throat and under parts tawny buff, marked on the throat with dark brown and on the breast with arrow-like brown markings; flanks and sides of the body tawny, the arrow-like marks being much heavier and larger; top of the head showing no central stripe of buffy white.

Adnlt in winter: Lacking the tawny color of the summer plumage: more whitish on the under parts, otherwise the markings being similar.

Length, I3; Wing, 8.10: Tarsus, 2: Bill, 2.75 to 3.50.

It ranges from the Arctic regions, where it breeds, southward to South America. At one time it was a very abundant bird on our coast during the migrations, but is becoming less common every year. It prefers the fields to the beaches, being often found in company with the Golden Plover. It is comparatively rare in Florida, but occurs regularly during migrations. The eggs are pate olive gray spotted with dark brown, mostly at the larger end.

\section{Family CIAARADritd.e. Plovers.}

\section{Genus CHARADRIUS Linn.}

\section{Subgenus SQUATAROLA Cuv.}

\section{CHARADRIUS SQUATAROLA (Limm.).}

\section{Black=bellied Plover. Beetle Head.}

Adult male in summer: Upper parts smoky black; feathers edged with dull white; breast black except in highest plumage, showing traces of whitish on the feathers : abdomen and under tail coverts white; forehead white; axillars smoky black.

Adult in winter: Upper plumage brownish mottled with gray; under parts white; breast and sides streaked with ashy brown; bill black.

Length, Ir.25; IVing, 7.45; Tarsus, 1.85 ; Bill, 1.10. 


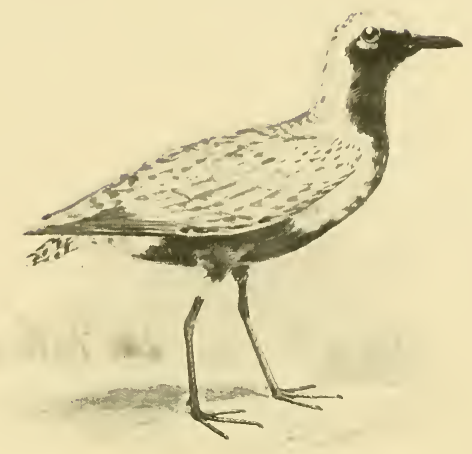

Charadrius squatarola (summer plumage).

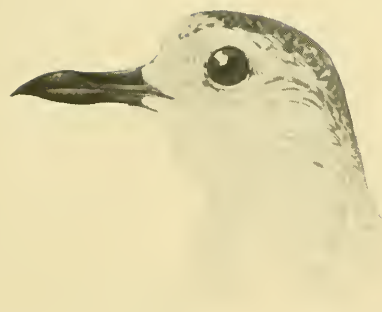

Charadrius squatarola (winter plumage).

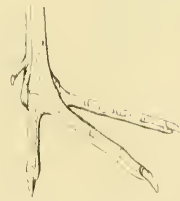

Charadrius squatarola (foot).

This species may always be distinguished from the Golden Plover by the presence of a rudimentary hind toe and the black axillars, which are gray in the Golden Plover.

It ranges from the Arctic regions to South America, being common on the Atlantic coast during migrations. It breeds in the far North: the eggs are usually four, pale olive brown, spotted and speckled with brown and black. 


\section{Subgenus CHARADRIUS Linn.}

\section{CHARADRIUS DOMINICUS Müll.}

\section{American Golden Plover.}

Summer plumage: Back and upper parts smoky black: feathers marked and edged with yellow and brown ; sides of the breast whitish ; rest of under parts, throat, and sides of the head, including eye, black; forehead whitish, a stripe extending backwards over the eye ; bill black.

Winter plumage: Upper parts brownish, feathers marked with dull tawny or buff; under parts are dull white streaked with ashy brown or gray on the breast and sides.

Length, 10.25: Wing, 7; Tarsus, 1.55: Bill, .92.

This species may always be distinguished in any plumage from the Black-breast Plover by the gray axillars and the absence of the small rudimentary hind toe.

It ranges from the Arctic regions to South America, being common on

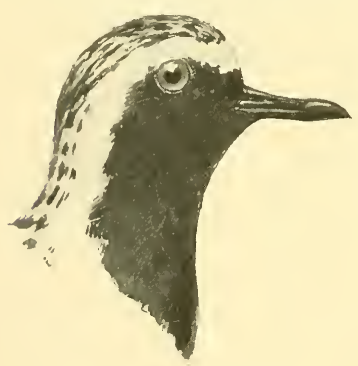
the coast during migration. It was at one time abundant in New England in the early fall, but its numbers have decreased greatly within the past few years. It is not a common bird in Florida, although it is occasionally taken in the State.

It breeds in the far North : the eggs are buff colored or brownish white mottled and marked with chocolate brown.

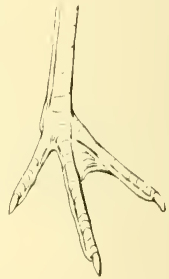

\section{Genus fEGIALITIS BoIE. Sitbgenus OXYECHUS Reich.}

\section{AEGIALITIS VOCIFERA (lim .). Killdeer Plover.}

Adult: Crown and back brownish gray, feathers tipped with rufous: a ring around the neck, lores, and a patch on the breast black: forehead white; throat and spot behind the eye and a band around the neck white; lower breast and belly white; tail coverts and rump bright rufous; tail rufous and gray tipped with black and white; bill black.

Length, 10.65: Wing, 6.55; Tarsus, I.40; Bill, .75.

The Killdeer Plover ranges on the Atlantic coast from Newfoundland to the northern part of South America. It is a rare bird on the New Eng- 
land coast as a rule. A few years ago there was a great flight of these birds along the coast of Massachusetts in December, and hundreds of them were sent to market and sold. I killed several near IJyannis, Mass., at that time.

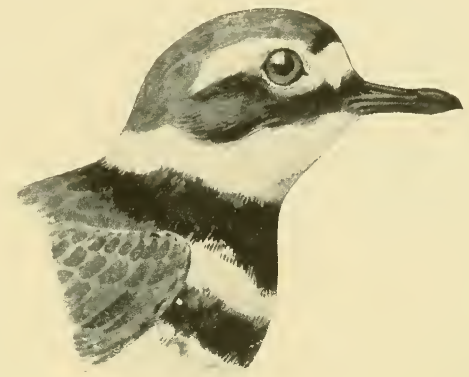

Egialites vocifera.

The Killdeer is a common bird in Florida. The egus are pale brownish white mottled and lined with chocolate brown.

Subgenus EEGIALITIS Bore.

AEGIALITIS SEMIPALIATA Bonat.

Semipalmated Plover. Ring=neck.

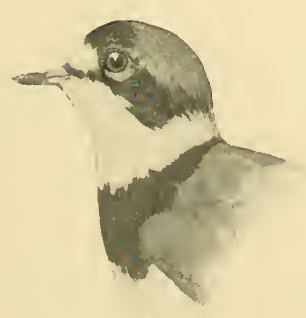

Adult: Forehead white, succeeded by a band of black; rest of head, back, and wings ashy gray: a dull stripe of blackish passing from the bill under the eye to the sides of the neck; a small patch of white back of the eye : a broad band of black on the breast; rest of under parts white; throat white, extending around the neck and joining at the back in a very narrow stripe : secondaries tipped with white; bill black, orange at the base; a bright orange ring around the eye.

Adult in summer: Toes with small webs.

Length, 6.8o; Wing, 4.75: Tarsus, .93; Bill, .50.

Ranges from the Arctic regions to South America, breeding from Labrador northward. It is a common species on our coast during the migrations. The eggs are usually four, pale brownish white spotted with chocolate brown. 
AEGIALITIS MIELODA (Ord).

Piping Plover.

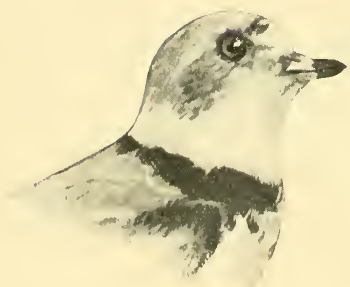

Adult in summer: Upper parts ashy: forehead white, separated from the ash color of the head by a narrow patch of black; a band on the side of the breast black; under parts and a ring around the neck white.

Adult in winter: Similar to the summer plumage, but the black marking replaced by grayish buff or ashy gray instead of black. Bill orange at base, tipped with black.

Length, , ); Wing. 4.So; Tarsus, .90; Bill, .50.

Ranges from Labrador to the West Indies and South America. It is a common species on the New England coast during the migrations, and is a regular winter visitant to Florida, although not abundant.

The Piping Plover breeds from Virginia to Labrador and Newfoundland. The eggs are dull white marked with dark brown.

\section{AEGIALITIS IIELODA CIRCUICINCTA Ridgre.}

\section{Belted Piping Plover.}

It is similar to 1 . meloda, but differs in having an unbroken black band from the sides around in front of the neck.

This species occurs on the coast during the migrations. I am not aware that it has been recorded from Florida, but it no doubt occurs there.

SUngeNUS OCHTHODROMUS REICH.

\section{AEGIALITIS WILSONIA (Ord.).}

\section{Wilson's Plover.}

Idult male: Above ashy brown; forehead white, extending into a faint superciliary stripe of dull black on the crown ; throat white, continuing on the sides of the neck, nearly joining upon the nape; a black pectoral band, the feathers edged with white, becoming brown upon the sides; under parts white: two central tail feathers brown, the others showing increasing markings of white to the outer tail feathers, which are white; bill black (large and stout) ; legs pinkish. 
Female and immature birds have the pectoral band brown, and no black on the hear.

Length, 7.45; WVing, 4.60; Tail, 1.90; Tarsus, 1.16; Bill, .90.

This is rather a Southern species, but stragglers have been taken as far north as Nova Sicotia.

It breeds from Virginia southward and is a common bird in Florida.

The eggs are usually three in number, dull white dotted and spotted with chocolate brown.

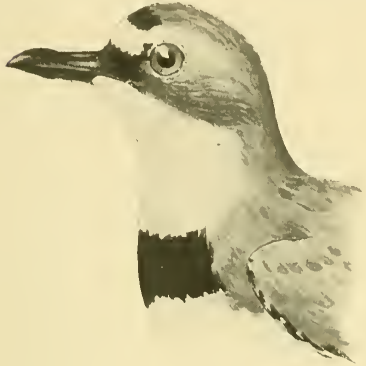

Egialitis wilsonia.

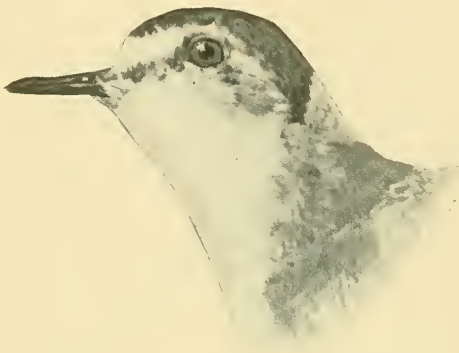

Egialitis montana.

\section{Subgenus PODASOCYS Coues.}

\section{AEGIALITIS MONTANA (Tozons.). \\ Mountain Plover.}

Above uniform brownish gray; feathers occasionally edged with tawny brown; under parts entirely white with the exception of the breast, which at times shows a tinge of gray: a black loral stripe extending from the bill to the eye, and a black superciliary stripe back of the bead. showing a patch of black: shafts of the first primary white: wing coverts grayish brown. some of them tipped with white; bill black ; legs pale brown.

Length, 8.75: Wing, 6: Tarsus, 1.60 : Bill, .95.

. Temperate North America from the great plains westward: accidental in Florida."

This species has been recorded from Florida, but it is not common in the State and must be considered as merely an accidental straggler.

The eggs are three to four in number, of olive brown color dotted and marked with brown. 


\section{Finily APIRIZID.E. Surf Birdas and Turnstones.} SABMMLY ARENARIIN/E. TIRNSTONES.

\section{GENU'S ARENARIA BRISSON.}

\section{ARENARIA INTERPRES (Limn.).}

\section{Turnstone.}

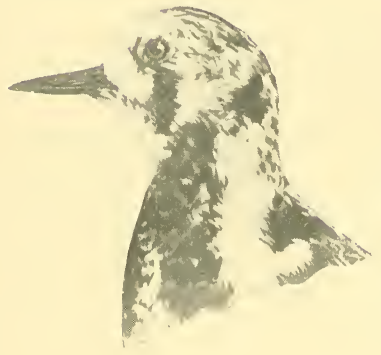

This species ranges from the Arctic regions to South America and is common during migrations on the Atlantic coast. It breeds in high latitudes; the eggs are pale clay color mottled and lined with dull brown. It is a common bird in Florida in winter.

\section{FAMILY II.EMATOPODID.E. Orster-catchers. \\ GENus H/EMATOPUS IINN.}

\section{HAMATOPUS PALLIATUS Temm. American Oyster $=$ catcher.}

IV inter plumage, male: Head and neck blackish or very dark brown; back brown ; lower part of breast and rest of under parts white; eyelids, rump, tips of wing coverts, part of secondaries, and basal portion of the tail feathers white: bill orange, darkening at the tip (in summer deep red); legs flesh color.

Length, 17.40; Wing, 10.05; Tail, 4.35; Tarsus, 2.30; Bill, 3.50 . 


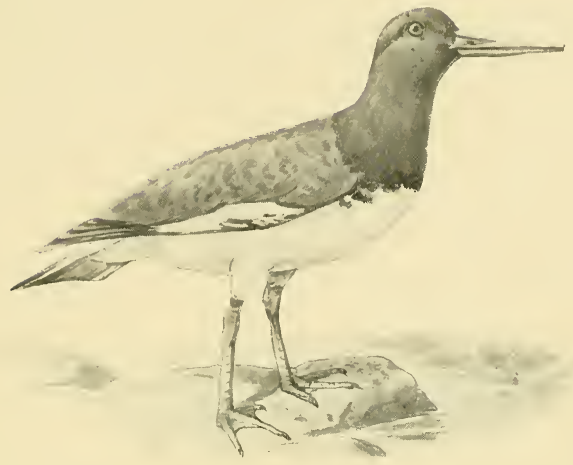

Hematopus palliatus.

This species occurs on the seacoast of temperate and tropical America, frequenting the beaches, where it is often met with in pairs or small flocks. It occasionally occurs as far North as New Jersey. Stragglers have been taken near Grand Menan, Maine, and on the coast of Massachusetts. It is a common species in Florida, where it breeds. The eggs are pale brownish white spotted with chocolate brown.

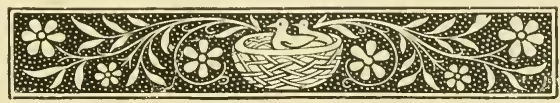





\title{
INDEX.
}

\author{
(1.1TIX.)
}

Ictitis macularia

Ictodromas

Egialitis

meloda

" circumcincta

montana .

semipalmata

vocifera

wilsonia

Listrelata hasitata .

lix sponsa .

Ајаја ајаја

Inas.

ansericana

boschas

carolinensis

cyanoptera

discors

fulvigula

obscura

strepera

Inatidx

Inatina

Ancylocheilus

Anhinga anhinga

Inhingida

Inous stolidus

Inser albifrons gambeli

Inseres

Inserina

Iphrizida

Iramida

Iramus giganteus

Irdea

coerulea

candidissima

egretta

herodias

occidentalis

rufescens

tricolor ruficolli.

virescens.

wardi

Irleida

wïerdemanıi

Arcleina

Ircletta

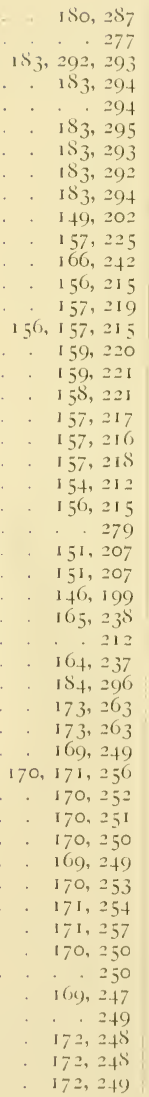

Arenaria interpre:

Irenariina

Arquatella.

Aythya .

affinis

americana

collaris

marila nearcticil

vallisneria

Bartramia longicauda

Botaurina

Botaurus lentiginosus

Branta

bernicla

canadensis

Butorides

Calidris arenaria .

Charadriida

('haradrius. dominicus squatarola

Charitonetta albeola

('haulelasmus

('hen

carulescens

hyperborea nivalis

('iconiz'

(iconiidix

( 'langula hyemalis

Colymbus auritus

Coturnicops.

C'reciscus.

(rymophilus fulicarius

( ygninæ

( yrtopelicanu.

(ymodroma grallaria

1)afila acuta

1)ichromanassit

1)iomedea exulans:

1) iomedeida.

1)ysporus

liremnetes

occidentalis

pusillus

Lirismatura rubida
$1 S_{4}, 200$

290

277

I 59, 226

I 60, I6I, 229

I $60,162,226$

$161,162,229$

$160,161,22 \mathrm{~S}$

159,227

178,286

. . 247

$171,2+7$

164,239

165,240

164,239

. 257

180,280

182,290

IS' 290,292

$18_{3}, 292$

182,290

I62, 231

. 215

164,237

165,237

164,237

. 246

165,246

161,232

$1+1,135$

. 267

267

270

165,240

. . 206

I 49,203

156,223

. 253

$1+8,201$

$\mathrm{I}+\mathrm{s}, 20 \mathrm{I}$

. 206

179, 279

179,2 SO

I So, 279

$162,23^{6}$ 
Floricla

Fregata acquila

Fregatidae.

Fulica americana

Fulicina

Fuligina

Fuligulina

Fuligula

(iallinago delicata

(iallinula galeata

(iallinulinx

(iarzetta

(ielochelidon nilotica

Cilaucionetta clangula americana

(ilottis

Girues

Gruida

Girus.

americana mexicana

Gilara

$$
\begin{aligned}
& \text { allia . } \\
& \text { rubra. }
\end{aligned}
$$

Ifx matopodida

Ilamatopus palliatus.

I Ierodias

Iferodii.

J Terodiones

1 limantopus mexicanus

llydranassa

1 y.drochelidon nigra surinamensis

Hides

Hidida.

Ionornis martinica

1.aricla

larina

l,arus

argentatus smithsonianus atricilla

delawarensis

marinus

philadelphia

l.imicola

l mosa.

fedoa

hamastic

I.ongipennes

1.ophodytes cucullatus

Macrorhamphus. grisens scolopaceus

Mareca.

Melanitta

Merganser.
-. 256

153,211

I 53,211

175,260

175,260

. 159

. 226

228

177,273

175,268

175,268

. 252

147,194

$161,162,231$

. . $2 \mathrm{S2}$

- 260

172,260

172,260

I 72,260

172,262

167,243

167,243

$167,168,24 t$

I 84,296

ISt. 296

. 251

247

$2+2$

176,272

. 254

147,199

. . 242

167,243

$175,26 \mathrm{~S}$

$1+4,191$

$1+4,191$

I $+4,191$

144,192

$1+4,193$

144,192

$1+4,191$

$\mathrm{I}+4,193$

- 270

I $1 \mathrm{O}, 2 \mathrm{SI}$

1 Sัo, $2 \mathrm{~S}_{3}$

ISI, $2 \mathrm{~S}_{2}$

. 189

155,214

177,275

177,275

177,275

. 219

. 234

I 54,212 americasa

154,212

serrator

$154,155,213$

Nergina

154,212

Vicropalama himantopus . . . . 179, 276

Nettion

. 220

Numenius.

borealis.

180,288

. . . . 182,290

I 30,288

Nyctherodius:

Nycticorax nycticorax nevius . . . . 171, $25 \mathrm{~S}$ violaceus . . . . . . 171, 259

Oceanites oceanicus

$1+9,203$

()chthodromus . . . . . . . . 294

Odontoglossac . . . . . . 241

()iclemia . . . . . . . 162, 233

americana . . . . . . 163, 233

deglandi . . . . . . 163,234

perspicillata . . . $162,163,235$

() lor columbiants . . . . . . 165, 240

()xyechus. . . . . . . . . . 292

Paludicole . . . . . . . 260

Pelecanida . . . . . . 152, 209

Pelecanus . . . . . . . 152, 209 erythrorhynchos. . . . . 152,209 fuscus . . . . . 152, 210

I'elidna. . . . . . . . . . 279

Pelionetta . . . . . . . . . . 235

Phaèthon flavirostris . . . . 149, 204

l'haëthonticlae . . . . . . . 149,204

Phalacrocroacida. . . . . 151, 208

I'halacrocorax dilophus Horidanus . 151, $20 \mathrm{~S}$

I'halaropodida . . . . . . . 176,270

l'halaropus lobatus . . . . . . . 176

l'hilohela minor . . . . . . 177,273

Phonicopterida. . 166, 241

l'hoenicopterus ruber . . . . . 166, 241

l'lataleidx . . . . . . 166, 242

l'legadis . . . . . 167,245 autumnalis . . . . . . 167, 245 guarauna ..... . 167,246

Podasocys . . . . . . . . . 295

Podiderpida . . . . . . IfI, IS5

J'odilymbus podiceps. . . . . 141, 186

Porzana . . . . . 174, 266 carolina...... . . $17+, 266$ jamaicensis noveboraceusis _... 174,267

l'rocellariida . . . . . . 148,201

l'uffinus . . . . . . . 148, 201 auduboni . . . . . 1 . 1 . . . 202 major. . . . . . 148,201

Pygopodes . . . . . . . . . $1 \$_{5}$

() verquedula . . . . . . . . 221 
Ralli .

Rallida

Rallina

Rallus

elegans.

longirostris crepitall. scottii

virginianus

Recurvirostra americana

Recurvirostridx . . .

Rhyacophilus

Rhynchopidx

Rhynchops nigra

Scolopacida

Spatula clypeata

iquatarola

Steganopodes

Stercorariidax

Stercorarius longicaudus: parasiticu

Sterna

anxthetus antillarum

dougalli

forsteri

fuliginosa

hirundo

maxima

sandvicensis acuflavicla

tschegrava
. . 263

173,264

173,264

173,264

173,264

173,265

174,266

174,265

176,271

176,271

. . 284

$\mathrm{I} 47,200$

147,200

177,273

158,222

. . 290

. . 204

$\mathrm{I}+3,189$

I 43,189

$1+3,190$

143,189

145,194

$1+6,198$

147,197

I 46,197

146,196

145,198

$1+5,196$

$1+5,195$

$1+5,195$

145,194
Sternina

Sula

bassana

cyanops

piscator sula

Sulidxe

Symphemia semipalnata

$$
\text { , inomata }
$$

Tantalinx

Tantalus loculator . . . .

Totanus

flavipe.

melanoleucus

nebularius

solitarius

Tringa .

alpina pacifica

canutus

fuscicollis

maculata .

maritima .

minutilla .

Tryngites subruficolli:

Tubinares

Lrinator

imber

lumme

Urinatorida
145,194

I 50,205

I 50,206

I 50,205

1 50,206

I 50,205

I 50,205

IS I, 285

I 81,285

$\mathrm{I} S \mathrm{I}, 2 \mathrm{~S} 6$

. 246

168,246

${ }_{17} \mathrm{~S}, 282$

178,283

$\mathrm{I} \mathrm{S}_{\mathrm{I}}, 2 \mathrm{~S}_{3}$

$\mathrm{I}_{2}, 282$

179, $2 S_{4}$

178,276

I 79,279

178,276

ISo, 278

178,277

I 79,277

180,278

I 79, 287

. 201

- $142,1 S_{7}$

I $+2,1 S 7$

I 42,185

- 142,187 


\title{
INDEX.
}

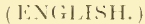

Albatross, II andering

Inhinga

Ivocet, American

Baldpate

lieetle-head

Bittern, Anerican Cory's Least Least.

l'luebill

liooby, Blue-faced . Common. Red-footed

Brant

Broadbill

Buffle-head

Bull-peep

Butter-ball .

Butter-bill

Canvas-back

Coot .

American

Black.

iea

sikunk-head

II hite-winged

f ormorant, Florida

c'ourlans

Crane, Sandhill

II hooping

Crying-bird

Curlew, Eskimo .

IIudsonian

Jack

l,ong-billed.

1)arters.

Jivers:

Cireat Northern

Red-throated

1) ough-bird

Jowitcher.

1)owitcher, I, ong-billed

l) ucks

American ciolden liye

Baldpate.

black
148,201
151,207
176,271
157,219
182,290
171,247
172,249
172,248
160,161
150,205
150,205
150,206
165,240
$. \quad . \quad 158$
162,231
.$\quad 250$
.$\quad 2$
.$\quad 231$
.$\quad 163$

159,227

163

175,269

. 233

. 235

162,163

163,234

151,208

. .263

172, 262

172,260

. 173

$\left[\mathrm{S}_{2}, 200\right.$

ISo, 289

- 180

I So, 288

I $5 \mathrm{i}, 207$

$1+2, \mathrm{IS}_{5}$

142,187

$1+2,188$

1 S' 2,290

177,275

177,275

154,212

$161,162,231$

. 219

I 57,216 bluebill

Broadbill

Buffle-head

Butter-ball

Butter-bil]

Canvas-back

I usky

Florida Black

" Dusky

Gadwall

Dusky

Mallard

Merganser, American Hooded

Red-breasted

Old Squas

old Wife

l'intail

Redhead .

Ring-necked

Ruddy

scaup, American ireater Lesser

Sheldrake

shoveller

Spirit

South Southerly

sprigtail .

Summer

Whistler.

Widgeon, Baldpate American .

IVood.

I) unlin, American

Egret, American .

Reddish

IVhite

Flamingo, Imerican

Floricla lilack 1)uck

Fulmar:

$$
\text { 1)usky }
$$

(iadwall

Gallinule, liloricla Puple

Gannets.
I 60,161

. $15^{8}$

I 62, 231

. 231

. 163

159,227

157,216

157,217

. . 217

$157,21 \mathrm{~S}$

$156,157,215$

I $5.4,2$ I 2

I 55,2 I 4

154,213

I 61,232

. . 232

I 56,223

$160,162,226$

$16 I, 162,229$

162,236

. . 228

I 60, I 6 I

$160,161,229$

. I 54

$15 \mathrm{~s}, 222$

231

232

- 232

157

$161,162,231$

- 157

219

157,225

. 179

170,251

170,253

170,252

I $66,24 \mathrm{I}$

157,217

. 217

- 201

I $57,21 \mathrm{~S}$

175,268

175,268

I 50, 205, 206 
Godwit, 1Iudsonian IIarbled

fiolden liye, American

(ioose, Imerican White-fronted 13 lut

Canada

Greater sinow

Crass-bird .

(irebe, Horned

l'ied-billed

(ireen-shank

(iull, Imerican Herring

linaparte':

(ireat Black-backed

laughing

Mackerel

Ring-billed

1leron, Black-crowned Night

ireat blue. . . .

Cireat White

ireen

little lilue

Louisiana

Sinowy

IV'ard's

Würdemann's

Vellow-crowned Night

ll)is, (ilossy

Sicarlet

White

IVhite-faced

IV ood

Jaeger, 1.ong-tailed

Parasitic

$$
\begin{array}{r}
181,282 \\
180,281 \\
161,162,231 \\
165,238 \\
165,237 \\
164,239 \\
164,237 \\
175,277 \\
141,185 \\
141,156 \\
182,282 \\
144,192 \\
144,193 \\
144,191 \\
144,193 \\
. \quad 196 \\
144,192
\end{array}
$$

$1-1,25 \mathrm{~S}$

170,250

169,249

171,257

$170,171,256$

171,254

I 70,250

. 250

171,259

167,245

$167,168,244$

I 67,243

I 67,246

I $6 S, 2+6$

$1+3,190$

$1+3,159$

Killdeer

Knot

$1 \mathrm{~S}_{3}, 292$

$17 \mathrm{~S}, 276$

Limpkin

L,oon

173,263

$1+2,1 S 7$

$1+2,1 S S$

Nallard

Man-o'-IV ar Birc

Merganser, Imerican

Hooded

Red-bredsted

Mother Cary's C'hicken

Iud-hen

() Id Squaw

()ld IVife

()yster-catcher, American

Pelican, American White Brown

P'etrel, Black-capperl

White-bellied

152,210

$1+9,202$

149.203
I 70,252

IVilson's

I'balarope, (iray

Northern

Red

l'intail

Plover, (iolden

Belted Piping

Black-bellied

black-breasted

Killdeer

Mountain

Piping

Ring-neck

Semipalmated

Upland

IVilson's.

49, 20.3

270

176

270

156,223

$15_{3}, 292$

294

290

182

183.292

is 3,295

183,294

$18_{3}, 293$

$\cdot 293$

$1-8,286$

$18_{3}, 294$

Rail, Black

Carolina

$17+, 267$

$17+, 266$

Clapper

Florida ('lapper

$173: 265$

King

Scott's

Virginia

Vellow

Redhead

- 266

173,264

$17+, 266$

$17+, 265$

$17+, 267$

160. 162,226

Ring-neck .

293

Sanderling

Sandpiper, Bartramian or bartram 's Buff-breasted

Least .

l'ectoral.

Purple

Red-backed.

Siemipalmated

Solitary

spotted

sitilt

So, $2 \mathrm{So}$

178,286

179,287

I So, $27 \mathrm{~S}$

I $7 \mathrm{~S}, 277$

179,277

179,279

180,279

$179,2 \mathrm{~S}_{4}$

1 So, 287

179,276

IV estern. 170

, semipalmated . . . . . 280

White-rumped . . . . . ISo, 278

Sicoter, American . . . . . . 163, 233

Surf . . . . 162, 163, 235

White-winged . . . . . 163, 234

Shearwater, Audubon's . . . . : 149,202

Greater...... . . 148,201

Sheldrakes . . . . . . . . . 154

Shoveller . . . . . . 158, 222

Sickle-bill . . . . . . . . 2SS

Skimmer, Black . . . . . . I 47,200

Snake Bird . . . . . . . . . i 51,207

Snipe, English . . . . . . . 177,273

Red-breasted . . . . . 177, 275

Robin . . . . . . . . 276

Western Red-breasted . . . . . . 275

Wilson's. . . . . . 177, 273

Sora. . . . . . . . 174,266

South Southerly

. 232 
Spoonbill, Roseate.

Sprigtail

sitil, Black-necked.

Storks

Swan, Whistling

fiwimmers, Long-winged .

Totipalmate

Tube-nosed

T'eal, lilue-winged

Cinnamon

Green-winged

T'ern, Black

Bridled

Cabot's

Caspian

Common

Forster's

iull-billed
166,242

. 223

176,272

. 168

165,240

. 189

204

201

$15 \mathrm{~S}, 22 \mathrm{I}$

I 59,221

159,220

$1+7,199$

$1+6,195$

145,195

145,194

I $+5,196$

I 46,106

I 47,194 least . . . . . 147, 197

Voddy . . . . . 1 . 46,199

Roseate . . . . . . 146, I 97

Royal . . . . . . . I 15,195

Sooty . . . . . . 145, 198

Tropic Bird, Vellow-billed . . . I 49,204

Turkey, Water . . . . . . [ 51, 207

Turnstone........ . . $1 \$_{4,296}$

Whistler . . . . 161, 162, 231

IVidgeon, American . . . . . . 219 Baldpate . . . . . . . . 157

IVillet . . . . . . $18 \mathrm{I}, 285$

, Western . . . . . 181, 286

Woodcock, American . . . . . 177, 273

Vellowlegs, Greater . . . . I $8_{\text {I }, 283}$

Summer . . . . . . . 178,283

Winter . . . . . . ${ }_{\mathbf{I}} \delta_{\mathbf{I}, 2} \mathrm{~S}_{3}$ 


\section{Works on Ornithology,}

by

\section{Charles B. Cory.}

\section{A Naturalist in the Magdalen Islands.}

Giving description of 'the islands and list of the birds taken there, with other ornithological notes. One vol., small quarto, illustrated. Isoston, U.S. A., r\$ $\$$ S.

$$
\text { Price . . . . . . \$ \$ } 50 .
$$

\section{The Birds of the Bahama Islands.}

Containing many species new to the islands, together with a number of undescribed winter plumages of North American birds. Illustrated with eight full-page plates. One vol., large quarto. Boston, U. S. A., 1880.

$$
\text { Price . . . . . . . } \$ 7.00 \text {. }
$$

Revised edition of same. Boston, U. S. A., r.sgo.

$$
\text { Price . . . . . . . } \$ 7.00 \text {. }
$$

\section{The Beautiful and Curious Birds of the World.}

A superb work, complete in seven parts (atlas folio), illustrated with twenty plates ( 2 I by 27 - beautifully colored, each plate finished by hand in water colors. The plates represent a $\mathrm{s}$ of beautiful and curious birds, extinct and living. Among the species illustrated are : s of Paradise, Dodo, Great Auk, Apteryx, Labrador Iuck, California Condor, Sacred Ibis, etc. Each plate is accompanied by descriptive text. The edition was limited to two huncopies and the stones were destroyed after that number were printed. Less than twenty ect sets now remain unsold. Boston. U. S. A., ISS 3 .

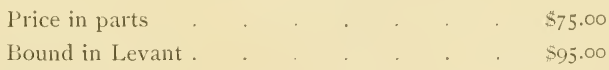

\section{he Birds of Haiti and San Domingo.}

Containing twenty-two full-page plates colored by hand in water colors. Large quarto, bound in cloth: the edition was limited to three hundred copies. Boston, L. S. A., ISS5.

Price $\$ 20 . C O$. 


\section{A List of the Birds of the West Indies.}

New edition, revised and enlarged, one vol., boards. Boston, U. S. A., 1 SS6.

Price

$\$ 1.00$.

\section{The Birds of the West Indies.}

Including all species known to occur in the Bahama Islands, the Greater and Lesser Antilles, excepting the islands of Tobago and Trinidad. The only exhaustive work on the birds of the West Indies that has yet been published. Illustrated with map and numerous cuts. One vol.. large quarto. bound in cloth. Boston, U. S. A., Isig.

Price . . . . . . . $\$ 5.00$.

\section{Catalogue of West Indian Birds.}

Containing a list of all species known to occur in the Bahama Islands, the Greater Antilles, the Caymans, and the Lesser Antilles, excepting the islands of Tobago and Trinidad, map. One vol., large quarto, bound in cloth. Boston. I. S. A.. 1892.

I'rice . . . . . . $\$ 2.50$.

\section{Hunting and Fishing in Florida.}

Including a key to the water birds of the State, illustrated with more than two hundred cuts and two full-page photogravures. Quarto, bound in cloth. Boston. (1. S. A., 1896.

Price $\$ 3.75$.

\section{Key to the Water Birds of Florida.}

Giving a description of all the water birds known to occur in the State. Illustrated with numerous cuts representing nearly every species. Boston, U. S. A., I\$96.

Price, paper, \$1.50, cloth

$\$ 1.75$.

These works may be obtained from

Estes \& Lauriat, Washington St., Boston, Mass.

Bradlee Whidden, 18 Arch St., Boston, Mass.

L. S. Foster, 35 Pine St., New York.

R. H. Porter, 18 Princes St., Cavendish Sq., London, England.

\section{In Course of Preparation.}

Check List of the Birds of Florida.

The Birds of Eastern North America. Key to the Birds of Illinois. 



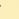



BOSTON PUBLIC LIBRARY

3 9999054954829 

this i

(1)

(1)

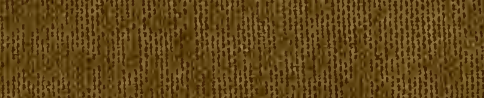

16.

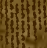
distip 